\title{
Annotated Bibliography of Scientific Research on Greater Sage-Grouse Published from 2015 to 2019
}

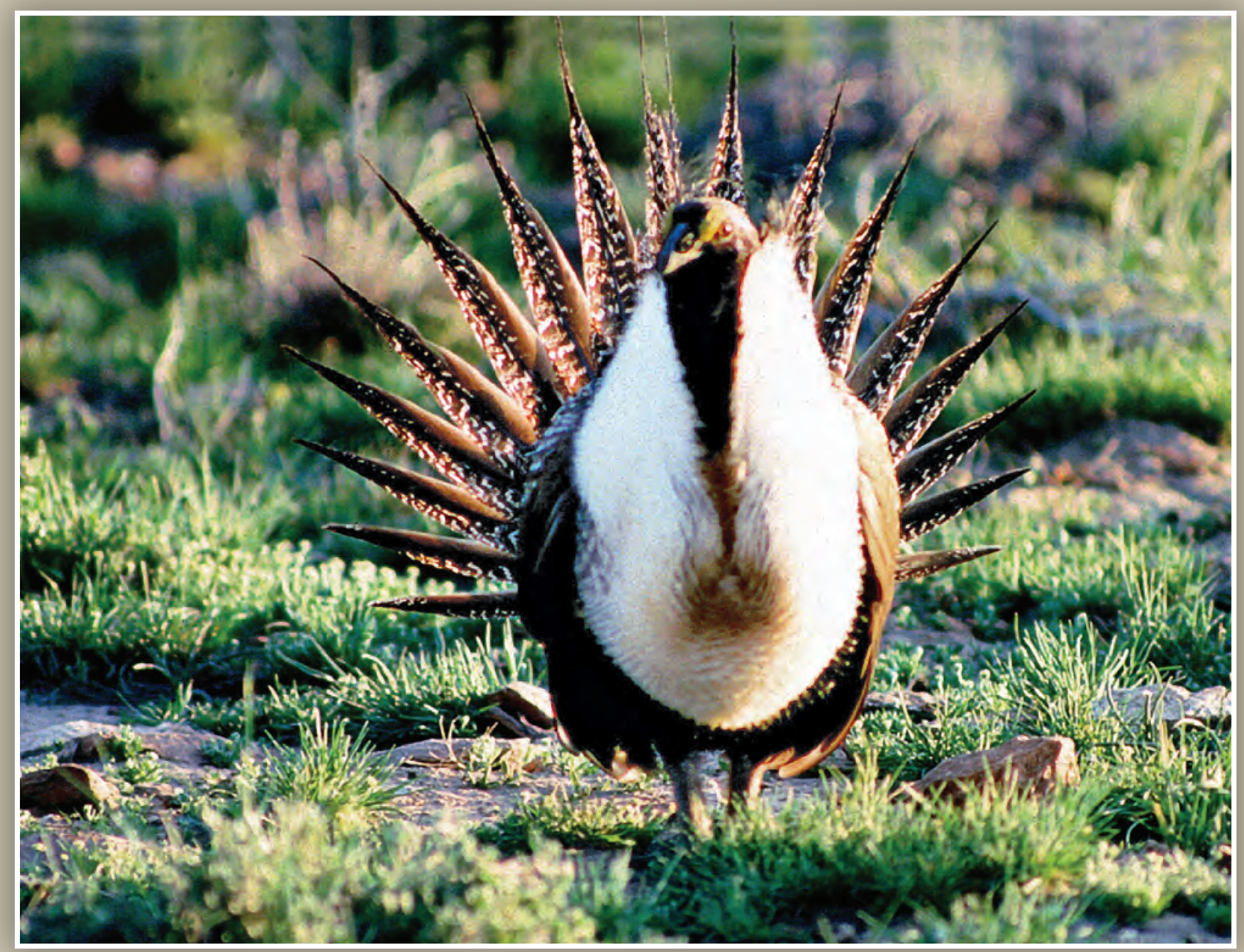

Open-File Report 2020-1103

Supersedes USGS Open-File Report 2018-1008 
Cover. A male greater sage-grouse displaying on a lek in Oregon.

Photograph by Bureau of Land Management Oregon and Washington. 


\section{Annotated Bibliography of Scientific Research on Greater Sage-Grouse Published from 2015 to 2019}

By Sarah K. Carter, Robert S. Arkle, Heidi L. Bencin, Benjamin R. Harms, Daniel J. Manier, Aaron N. Johnston, Susan L. Phillips, Steven E. Hanser, and Zachary H. Bowen

Open-File Report 2020-1103

Supersedes USGS Open-File Report 2018-1008 


\title{
U.S. Department of the Interior \\ DAVID BERNHARDT, Secretary
}

\author{
U.S. Geological Survey \\ James F. Reilly II, Director
}

U.S. Geological Survey, Reston, Virginia: 2020

For more information on the USGS—-the Federal source for science about the Earth, its natural and living resources, natural hazards, and the environment-visit https://www.usgs.gov/ or call 1-888-ASK-USGS (1-888-275-8747).

For an overview of USGS information products, including maps, imagery, and publications, visit https:/store.usgs.gov.

Any use of trade, firm, or product names is for descriptive purposes only and does not imply endorsement by the U.S. Government.

Although this information product, for the most part, is in the public domain, it also may contain copyrighted materials as noted in the text. Permission to reproduce copyrighted items must be secured from the copyright owner.

Suggested citation:

Carter, S.K., Arkle, R.S., Bencin, H.L., Harms, B.R., Manier, D.J., Johnston, A.N., Phillips, S.L., Hanser, S.E., and Bowen, Z.H., 2020, Annotated bibliography of scientific research on greater sage-grouse published from 2015 to 2019: U.S. Geological Survey Open-File Report 2020-1103, 264 p., https://doi.org/10.3133/ofr20201103.

ISSN 2331-1258 (online) 


\section{Contents}

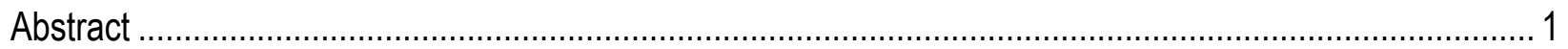

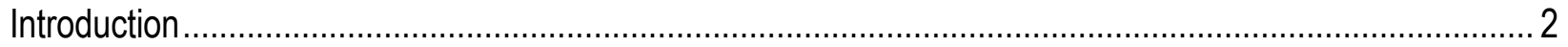

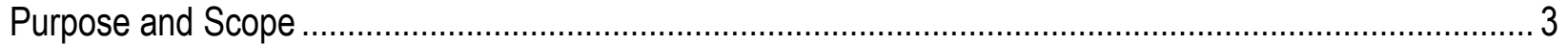

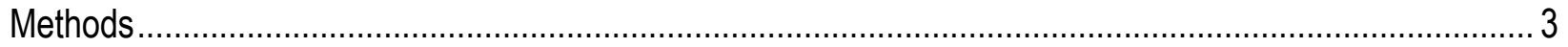

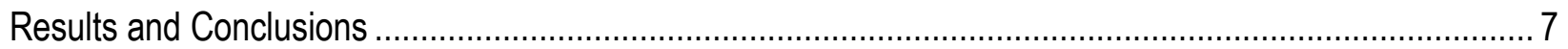

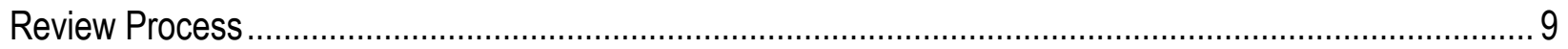

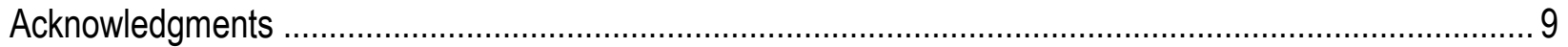

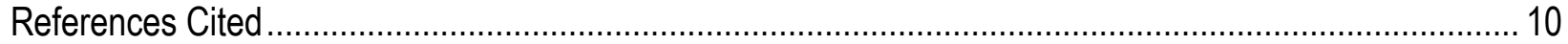

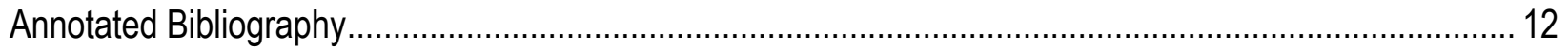

\section{Figure}

Figure 1. The current and historic distribution of greater sage-grouse habitat in the western

United States and the seven Greater sage-grouse Management Zones in the western United States .........5

\section{Tables}

Table 1. Information categories in each summary ................................................................... 4

Table 2. Management topics assessed for each journal article/report included in the bibliography ........... 6

Table 3. Number of products addressing each management topic .................................................... 8 


\section{Conversion Factors}

U.S. customary units to International System of Units

\begin{tabular}{|c|c|c|}
\hline Multiply & By & To obtain \\
\hline \multicolumn{3}{|c|}{ Length } \\
\hline mile (mi) & 1.609 & kilometer $(\mathrm{km})$ \\
\hline \multicolumn{3}{|c|}{ Area } \\
\hline acre & 4,047 & square meter $\left(\mathrm{m}^{2}\right)$ \\
\hline acre & 0.4047 & hectare (ha) \\
\hline acre & 0.004047 & square kilometer $\left(\mathrm{km}^{2}\right)$ \\
\hline
\end{tabular}

International System of Units to U.S. customary units

\begin{tabular}{|c|c|c|}
\hline Multiply & By & To obtain \\
\hline \multicolumn{3}{|c|}{ Length } \\
\hline meter $(\mathrm{m})$ & 3.281 & foot $(\mathrm{ft})$ \\
\hline kilometer $(\mathrm{km})$ & 0.6214 & mile (mi) \\
\hline meter $(\mathrm{m})$ & 1.094 & yard (yd) \\
\hline \multicolumn{3}{|c|}{ Area } \\
\hline hectare (ha) & 2.471 & acre \\
\hline square kilometer $\left(\mathrm{km}^{2}\right)$ & 247.1 & acre \\
\hline hectare (ha) & 0.003861 & square mile $\left(\mathrm{mi}^{2}\right)$ \\
\hline square kilometer $\left(\mathrm{km}^{2}\right)$ & 0.3861 & square mile $\left(\mathrm{mi}^{2}\right)$ \\
\hline
\end{tabular}

\section{Abbreviations}

$\begin{array}{ll}\text { BLM } & \text { Bureau of Land Management } \\ \text { DNA } & \text { deoxyribonucleic acid (genetic code) } \\ \text { GPS } & \text { Global Positioning System } \\ \text { GRSG } & \text { greater sage-grouse (Centrocercus urophasianus) } \\ \text { MZ } & \text { Greater sage-grouse Management Zone } \\ \text { PAC } & \text { Priority Area for Conservation } \\ \text { USDA } & \text { U.S. Department of Agriculture } \\ \text { USGS } & \text { U.S. Geological Survey }\end{array}$

\section{Species Names}

Plant nomenclature follows usage by the U.S. Department of Agriculture Natural Resources Conservation Service

(https://plants.usda.gov). Animal nomenclature follows usage by the Integrated Taxonomic Information System (https://itis.gov).

Common name
American kestrel
American mink
badger
beetles
big sagebrush
black grouse
black sagebrush
Brewer's sparrow
bobcat
cat (domestic or feral)
cattle (domestic)
cheatgrass (downy brome)
chicken
Colorado pinyon

Common name

American kestre

American mink

beetles

big sagebrush

black grouse

black sagebrush

Brewer's sparrow

cat (domestic or feral)

cattle (domestic)

chicken

Colorado pinyon

\author{
Scientific name \\ Falco sparverius Linnaeus \\ Neovison vison Schreber (formerly Mustela vison Schreber) \\ Taxidea taxus Schreber \\ Coleoptera [order] \\ Artemisia tridentata Nuttall \\ Lyrurus tetrix Linnaeus \\ Artemisia nova A. Nelson \\ Spizella breweri Cassin \\ Lynx rufus Schreber \\ Felis catus Linnaeus \\ Bos taurus Linnaeus \\ Bromus tectorum Linnaeus \\ Gallus domesticus ${ }^{1}$ \\ Pinus edulis Engelmann
}




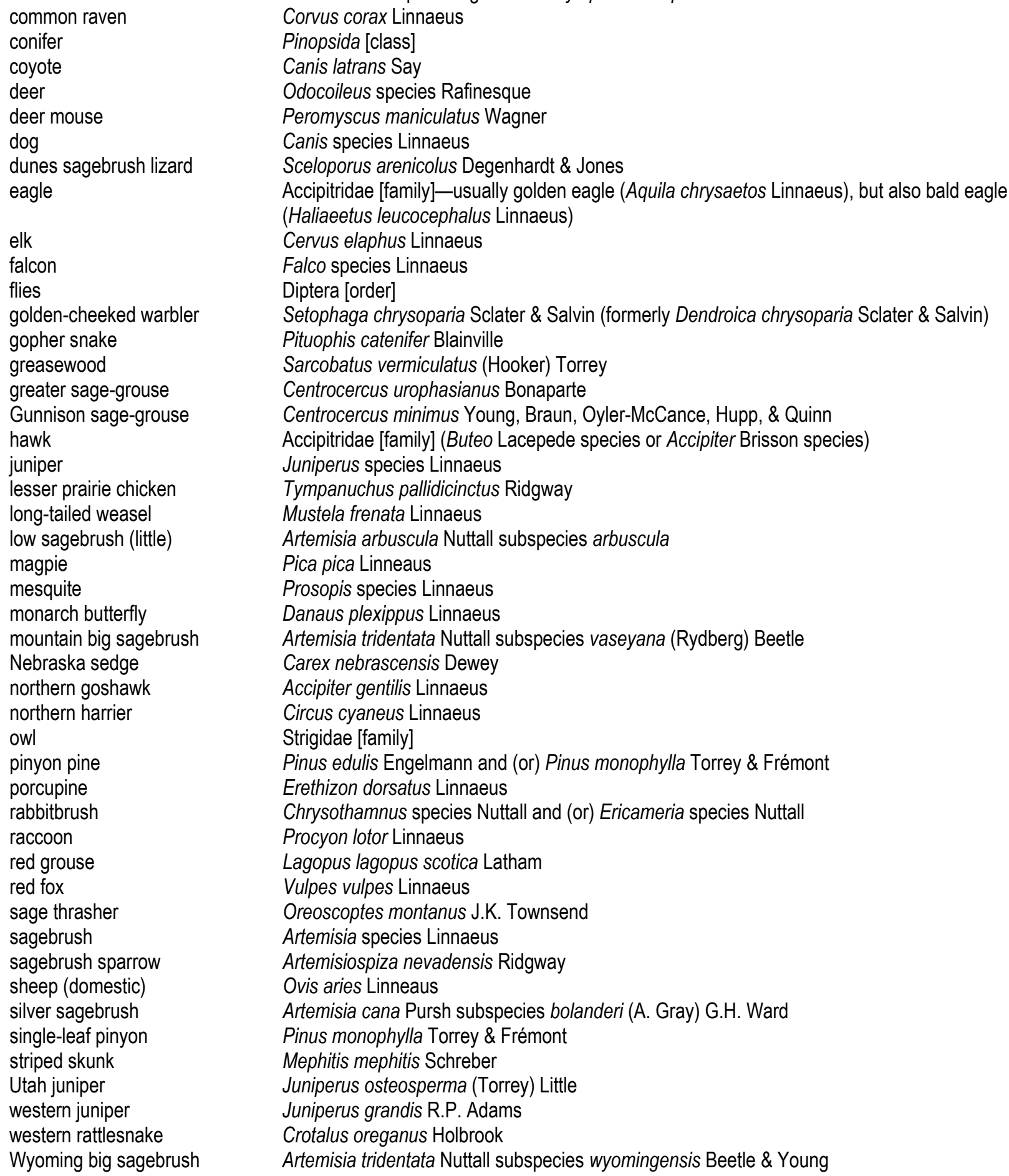

Corvus corax Linnaeus

Pinopsida [class]

Canis latrans Say

Odocoileus species Rafinesque

Peromyscus maniculatus Wagner

Canis species Linnaeus

Sceloporus arenicolus Degenhardt \& Jones

Accipitridae [family]—usually golden eagle (Aquila chrysaetos Linnaeus), but also bald eagle

(Haliaeetus leucocephalus Linnaeus)

Cervus elaphus Linnaeus

Falco species Linnaeus

Diptera [order]

Setophaga chrysoparia Sclater \& Salvin (formerly Dendroica chrysoparia Sclater \& Salvin)

Pituophis catenifer Blainville

Sarcobatus vermiculatus (Hooker) Torrey

Centrocercus urophasianus Bonaparte

Centrocercus minimus Young, Braun, Oyler-McCance, Hupp, \& Quinn

Accipitridae [family] (Buteo Lacepede species or Accipiter Brisson species)

Juniperus species Linnaeus

Tympanuchus pallidicinctus Ridgway

Mustela frenata Linnaeus

Artemisia arbuscula Nuttall subspecies arbuscula

Pica pica Linneaus

Prosopis species Linnaeus

Danaus plexippus Linnaeus

Artemisia tridentata Nuttall subspecies vaseyana (Rydberg) Beetle

Carex nebrascensis Dewey

Accipiter gentilis Linnaeus

Circus cyaneus Linnaeus

Strigidae [family]

Pinus edulis Engelmann and (or) Pinus monophylla Torrey \& Frémont

Erethizon dorsatus Linnaeus

Chrysothamnus species Nuttall and (or) Ericameria species Nuttall

Procyon lotor Linnaeus

Lagopus lagopus scotica Latham

Vulpes vulpes Linnaeus

Oreoscoptes montanus J.K. Townsend

Artemisia species Linnaeus

Artemisiospiza nevadensis Ridgway

Ovis aries Linneaus

Artemisia cana Pursh subspecies bolanderi (A. Gray) G.H. Ward

Pinus monophylla Torrey \& Frémont

Mephitis mephitis Schreber

Juniperus osteosperma (Torrey) Little

Juniperus grandis R.P. Adams

Crotalus oreganus Holbrook

Artemisia tridentata Nuttall subspecies wyomingensis Beetle \& Young

Columbian sharp-tailed grouse Tympanuchus phasianellus columbianus Ord

1Source: U.S. Department of Agriculture, 2000, U.S. trade descriptions for poultry: U.S. Department of Agriculture, Marketing and Regulatory Programs, Agricultural Marketing Service, Poultry Programs, AMS 71, accessed January 24, 2018, at https://www.ams.usda.gov/sites/default/files/media/Chicken_Trade_Descriptions\%5B1\%5D.pdf. 



\title{
Annotated Bibliography of Scientific Research on Greater Sage-Grouse Published from 2015 to 2019
}

\author{
By Sarah K. Carter, Robert S. Arkle, Heidi L. Bencin, Benjamin R. Harms, Daniel J. Manier, Aaron N. \\ Johnston, Susan L. Phillips, Steven E. Hanser, and Zachary H. Bowen
}

\begin{abstract}
The greater sage-grouse (Centrocercus urophasianus; hereafter GRSG) has been a focus of scientific investigation and management action for the past two decades. The 2015 U.S. Fish and Wildlife Service listing determination of "not warranted" was in part due to a large-scale collaborative effort to develop strategies to conserve GRSG populations and their habitat and to reduce threats to both. New scientific information augments existing knowledge and can help inform updates or modifications to existing plans for managing GRSG and sagebrush ecosystems. However, the sheer number of scientific publications can be a challenge for managers tasked with evaluating and determining the need for potential updates to existing planning documents. To assist in this process, the U.S. Geological Survey (USGS) has reviewed and summarized the scientific literature published since January 1, 2015. The first GRSG literature summary was published early in 2018. Here we provide an update to that document by adding summaries of articles published between January 6, 2018 and October 2, 2019.

To identify articles and reports published about GRSG, we first conducted a structured search of three reference databases (Web of Science, Scopus, and Google Scholar) using the search term "greater sage-grouse." We refined the initial list of products by (1) removing duplicates, (2) excluding products that were not published as research or scientific review articles in peer-reviewed journals or as formal technical reports, and (3) retaining only those products for which GRSG or their habitat was a research focus.

We summarized the contents of each product by using a consistent structure (background, objectives, methods, location, findings, and implications) and assessed the content of each product relevant to a list of 31 management topics. These topics include GRSG biology and habitat characteristics along with potential management actions, land uses, and environmental factors related to GRSG management and conservation. We also noted which articles/reports created new geospatial data.

Our original search, conducted on January 7, 2018, and the application of our criteria, resulted in the inclusion of 169 published products ( 2 of these products were published corrections to journal articles). This update adds summaries of 69 products published between then and October 2, 2019. The management topics most commonly addressed were GRSG behavior or demographics and GRSG habitat selection or habitat characteristics at broad or site scales. Few products addressed captive breeding, recreation, wild horses and burros, and range management structures (including fences). The management topics with the largest increase in representation between the 2018 GRSG literature summary and this update were GRSG survival and GRSG population estimates or targets, which were each addressed in 16 percent of products
\end{abstract}


in the original literature summary document, but were addressed in 30 and 33 percent, respectively, of newly summarized products. Topics with the largest declines in representation were conifer expansion, - 17 to 10 percent, and new geospatial data, -31 to 21 percent. We include in this annotated bibliography the full citation, Digital Object Identifier (DOI), product summary, and management topics addressed by each product. The online version of this bibliography (https://apps.usgs.gov/gsgbib/index.php) is searchable by topic and location and includes links to journal landing pages for each original publication.

A substantial body of literature has been compiled on research explicitly related to the conservation, management, monitoring, and assessment of GRSG. These studies may inform planning and management actions that seek to balance conservation, economic, and social objectives and manage diverse resource uses and values across the western United States.

The review process for this product included requesting input on each summary from one or more authors of the original peer-reviewed article or report and a formal review of the entire document by three independent reviewers for the original document and by two independent reviewers for the updated document and, subsequently, the USGS Bureau Approving Official. This process is consistent with USGS Fundamental Science Practices.

\section{Introduction}

The greater sage-grouse (Centrocercus urophasianus; hereafter GRSG) has been a focus of scientific investigation and management action for the past two decades, as the U.S. Fish and Wildlife Service (USFWS) has reviewed a series of petitions to list the species under the Endangered Species Act of 1973. The listing petitions were filed as a result of long-term declines in GRSG population numbers and distribution (Schroeder and others, 2004; Knick and Connelly, 2011; Western Association of Fish and Wildlife Agencies, 2015). These declines are primarily attributed to the loss and degradation of sagebrush habitat from threats including fire, invasive species, and human activity (Connelly and others, 2000; Schroeder and others, 2004; Knick and Connelly, 2011; U.S. Fish and Wildlife Service, 2013).

The most recent USFWS listing determination of "not warranted" in 2015 (U.S. Fish and Wildlife Service, 2015) was attributed to large-scale collaborative efforts to conserve GRSG populations and their habitat by reducing threats to both. These efforts included amending existing Bureau of Land Management (BLM) and U.S. Department of Agriculture (USDA) Forest Service land use plans (such as Bureau of Land Management, 2015a, b) and continuing implementation of the U.S. Department of the Interior (USDOI) Integrated Rangeland Fire Management Strategy (U.S. Department of the Interior, 2015). The large body of scientific literature on GRSG and the species' response to habitat conditions and threats informed both efforts. However, many uncertainties remain in our understanding of how GRSG respond to changes in their environment, and the scientific community has continued to conduct new studies to strengthen the science foundation for GRSG management and conservation.

New scientific information augments existing knowledge and can help inform updates or modifications to existing plans for managing GRSG and their habitat and strategies for alleviating threats to both. However, the sheer number of scientific publications developed over time can pose a daunting challenge for managers tasked with evaluating and determining the need for potential updates to existing planning documents. To assist in this process, the U.S. Geological Survey (USGS) has reviewed and summarized the scientific literature published since the last large-scale GRSG planning effort was completed in 2015. Our first GRSG literature summary was published in Carter and others (2018), and here, we provide an update to that 
document by adding summaries of articles published between January 6, 2018 and October 2, 2019. Although this annotated bibliography does not replace the need to read the primary literature, we hope that this document will provide a valuable, plain language reference for planners and managers responsible for managing natural resources within the GRSG range.

\section{Purpose and Scope}

This annotated bibliography was developed to catalog and summarize peer-reviewed scientific journal articles and reports about GRSG published since the records of decision were completed for the 2015 BLM and USDA Forest Service land use plan amendments for GRSG. As this document is focused on the set of peer-reviewed journal articles and formal technical reports published after January 1, 2015, it does not contain the large body of literature on GRSG developed prior to 2015 .

Management of GRSG and their habitat is a topic of ongoing scientific interest and management concern. As such, information from the 2018 document is being updated here and could be updated in the future to serve as a readily accessible, up-to-date resource for managers, planners, and administrators who need a quick reference to recent GRSG literature.

\section{Methods}

We conducted a structured search of three reference databases-Web of Science, Scopus (accessed through the USGS Library), and Google Scholar (accessed through Publish or Perish) — using the search term "greater sage-grouse." The search returned all items containing the search term in the product title, abstract, keywords, main text, or references (that is, a "topic" search). Products containing the search term only in the references were subsequently excluded. The initial search documented in Carter and others (2018) was focused on products published between January 1, 2015 and January 6, 2018. Products published between January 7, 2018 and October 2, 2019 were captured using the same search for this update.

We refined the initial list of products in four ways. First, we removed duplicate items. Second, we retained only those articles with the phrase "greater sage-grouse" present in the article title, abstract, or author-supplied keywords (when available) and in the main text of the article to ensure that the article focus was GRSG. Third, we excluded products that were not published as research or scientific review articles in peer-reviewed journals or as formal technical reports; this exclusion helped ensure that all products presented final work that had gone through a structured peer-review process. Accordingly, we excluded editorial content (such as policy perspectives and commentaries), reports without evidence of a formal peer-review process (such as project and annual reports without a technical series or volume number and a permanent digital object identifier), conference abstracts, article preprints, articles in magazines (for which there was no reference to a peer-review process), articles in journals for which we could not find evidence of a comprehensive peer-review process, theses, dissertations, manuscripts not yet in press, and books. Finally, we excluded any remaining articles or reports that, upon review, did not have content of clear relevance to conservation and management of GRSG. For example, we excluded articles that were primarily about another species with GRSG mentioned only in passing, often in the Introduction or Discussion sections for context or comparison.

In Carter and others (2018), we parsed the final list of articles and reports among five scientists to develop summaries of each product. Four scientists developed summaries for this 
update. Each scientist read an article or report, summarized its contents using a consistent structure (table 1), and identified the management topics addressed (table 2).

Location information included both the state(s) or province(s) and the Sage-Grouse Management Zone(s) where the research was conducted (figure 1), when possible. In some cases, however, specific location information was not made clear in the article/report.

Considerable information was distilled from each article/report in developing the summary. The target length for summaries was short (250-300 words); as a result, the source documents should always be consulted directly for more specific information.

Table 1. Information categories in each summary.

\begin{tabular}{|c|c|}
\hline Heading & Description \\
\hline DOI & $\begin{array}{l}\text { A Digital Object Identifier used to permanently identify an article or document and link it to its } \\
\text { source on the internet. }\end{array}$ \\
\hline Background & $\begin{array}{l}\text { A short description of the background and context for the study, explaining, in essence, the reason } \\
\text { for the study. }\end{array}$ \\
\hline Objectives & A concise statement of the study objectives. \\
\hline Methods & $\begin{array}{l}\text { A general description of study methods, including sample sizes and years and analysis } \\
\text { approaches. }\end{array}$ \\
\hline Location & $\begin{array}{l}\text { The location (state(s) or province(s) and Sage-Grouse Management Zone(s)) where the study took } \\
\text { place. }\end{array}$ \\
\hline Findings & $\begin{array}{l}\text { A description of the main findings of the study. If the study addressed multiple species, this } \\
\text { section focused on results related to GRSG. }\end{array}$ \\
\hline Implications & $\begin{array}{l}\text { A brief description of broader implications or management relevance of the study findings as they } \\
\text { were stated in the article or report. }\end{array}$ \\
\hline Topics & A list of the management topics addressed by the study. \\
\hline \multicolumn{2}{|c|}{$\begin{array}{l}\text { The scientist responsible for each article/report assessed its content relevant to a } \\
\text { structured set of management topics that included GRSG biology and habitat characteristics } \\
\text { along with potential management actions, land uses, and environmental factors related to GRSG } \\
\text { management and conservation (table 2). These management topics were derived from a number } \\
\text { of sources, including a } 2017 \text { report examining consistency issues in BLM resource management } \\
\text { plans across the GRSG range (U.S. Department of the Interior, 2017), a } 2013 \text { report summarizing } \\
\text { objectives for the conservation and survival of GRSG (U.S. Fish and Wildlife Service, 2013), } \\
\text { and conversations with USGS and BLM staff regarding additional GRSG science topics that they } \\
\text { anticipated would be useful to document and have available in the online version of this } \\
\text { document. Scientists also noted in their summaries if an article/report included new geospatial } \\
\text { data, as such data may be relevant for informing future GRSG management decisions. The list of } \\
\text { GRSG management topics is not meant to be exhaustive, but rather it is meant to be used to } \\
\text { facilitate searching of the article summaries for future science, policy, and management } \\
\text { purposes. }\end{array}$} \\
\hline
\end{tabular}



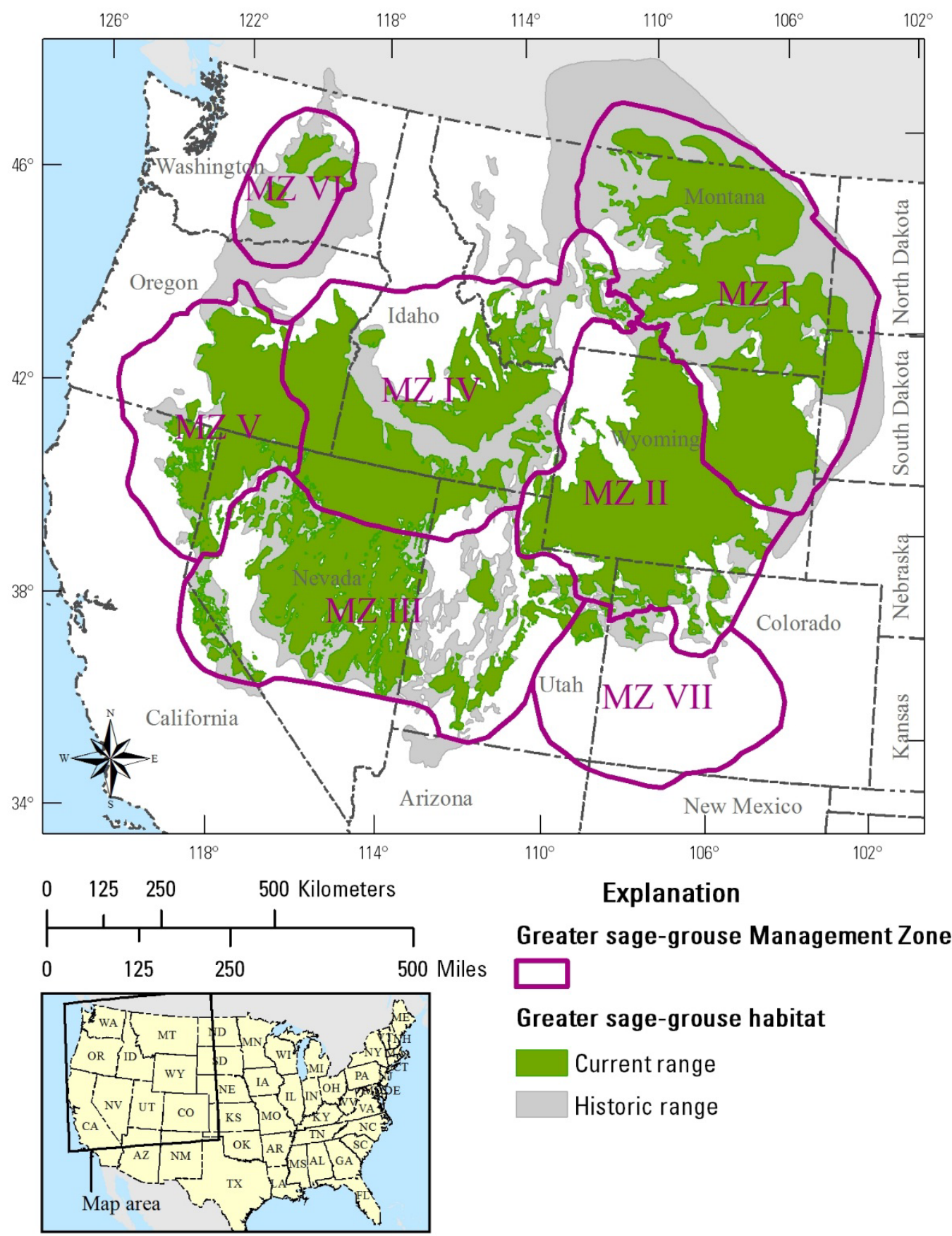

Figure 1. The current and historic distribution of greater sage-grouse habitat in the western United States and the seven Greater sage-grouse Management Zones in the western United States. (Data from U.S. Geological Survey 2014a, b, 2016.) 
Table 2. Management topics assessed for each journal article/report included in the bibliography.

\begin{tabular}{|c|c|}
\hline Management topic & Description \\
\hline Survival & Study quantified species survival rates, often in relation to environmental conditions. \\
\hline $\begin{array}{l}\text { Behavior or } \\
\text { demographics }\end{array}$ & $\begin{array}{l}\text { Study measured or modeled aspects of species behavior or demographics (for example, } \\
\text { seasonal movements, reproductive success, vital rates). }\end{array}$ \\
\hline $\begin{array}{l}\text { Population estimates or } \\
\text { targets }\end{array}$ & $\begin{array}{l}\text { Study estimated or modeled species population numbers, trends, dynamics, assessment } \\
\text { methods, or responses to the environment. }\end{array}$ \\
\hline Captive breeding & Study developed methods for or evaluated the success of captive breeding efforts. \\
\hline Translocation & Study developed methods for or evaluated the success of species translocation efforts. \\
\hline Genetics & $\begin{array}{l}\text { Study used genetic evidence to investigate species biology (for example, population } \\
\text { structure, connectivity, behavior). }\end{array}$ \\
\hline $\begin{array}{l}\text { Broad-scale habitat } \\
\text { characteristics }\end{array}$ & $\begin{array}{l}\text { Study addressed landscape-level habitat characteristics (for example, size, number, or } \\
\text { connectivity of habitat patches; characteristics of linkage areas; effects of landscape } \\
\text { context on habitat quality; availability or use of seasonal habitats), usually across large } \\
\text { areas. }\end{array}$ \\
\hline $\begin{array}{l}\text { Site-scale habitat } \\
\text { characteristics }\end{array}$ & $\begin{array}{l}\text { Study addressed habitat characteristics at the local level (for example, nest sites, brood- } \\
\text { rearing areas), typically based on field measurement of vegetation or soils. }\end{array}$ \\
\hline Habitat selection & $\begin{array}{l}\text { Study analyzed habitat characteristics selected by the species, typically based on a } \\
\text { combination of habitat characterization and telemetry or direct observations of } \\
\text { individuals. }\end{array}$ \\
\hline $\begin{array}{l}\text { Habitat restoration or } \\
\text { reclamation }\end{array}$ & $\begin{array}{l}\text { Study addressed methods for habitat restoration or the responses of the species or their } \\
\text { habitat to habitat reclamation or restoration efforts. }\end{array}$ \\
\hline New geospatial data & $\begin{array}{l}\text { Study created new geospatial data relevant to policy, planning, or management decisions } \\
\text { about the species. }\end{array}$ \\
\hline $\begin{array}{l}\text { Human dimensions or } \\
\text { economics }\end{array}$ & $\begin{array}{l}\text { Study addressed the human dimensions or economics of policy, planning, or } \\
\text { management decisions about the species. }\end{array}$ \\
\hline $\begin{array}{l}\text { Effect distances or } \\
\text { spatial scale }\end{array}$ & $\begin{array}{l}\text { Study addressed the spatial scale or distance effects of ecological or anthropogenic } \\
\text { features or processes on the species (for example, estimated distance that the species } \\
\text { may be displaced by or respond to a disturbance or environmental feature). }\end{array}$ \\
\hline Hunting & Study addressed effects of hunting on species populations or demographics. \\
\hline Recreation & $\begin{array}{l}\text { Study addressed effects of recreation infrastructure (such as trails) or activities on } \\
\text { species habitat, populations, or individuals. }\end{array}$ \\
\hline $\begin{array}{l}\text { Predators or predator } \\
\text { control }\end{array}$ & $\begin{array}{l}\text { Study identified predators of the species or addressed predator populations, the effects of } \\
\text { specific predators on the species, or the effects of predator control on the species. }\end{array}$ \\
\hline Fire or fuel breaks & Study addressed effects of fire or fuel breaks on the species or their habitat. \\
\hline $\begin{array}{l}\text { Nonnative invasive } \\
\text { plants }\end{array}$ & $\begin{array}{l}\text { Study addressed effects of nonnative invasive plant species (or efforts to control those } \\
\text { species) on the species or their habitat. }\end{array}$ \\
\hline Sagebrush removal & $\begin{array}{l}\text { Study addressed effects of intentional sagebrush removal treatments on species habitat, } \\
\text { populations, or individuals. }\end{array}$ \\
\hline
\end{tabular}


Table 2. Management topics assessed for each journal article/report included in the bibliography. Continued

\begin{tabular}{|c|c|}
\hline Management topic & Description \\
\hline Conifer expansion & $\begin{array}{l}\text { Study addressed effects of conifer expansion or conifer removal treatments on species } \\
\text { habitat, populations, or individuals. }\end{array}$ \\
\hline Wild horses and burros & $\begin{array}{l}\text { Study addressed effects of wild horses or burros on species habitat, populations, or } \\
\text { individuals. }\end{array}$ \\
\hline Herbivory/grazing & $\begin{array}{l}\text { Study addressed effects of herbivory (wild or domestic) on species habitat, populations, } \\
\text { or individuals. }\end{array}$ \\
\hline Fences & Study assessed effects of fences on species survival or behavior. \\
\hline $\begin{array}{l}\text { Other range management } \\
\text { structures }\end{array}$ & $\begin{array}{l}\text { Study addressed effects of other range improvement structures (for example, water } \\
\text { developments, mineral licks) on the species, their habitat, or their predators. }\end{array}$ \\
\hline Energy development & $\begin{array}{l}\text { Study addressed effects of energy development on species habitat, populations, or } \\
\text { individuals. }\end{array}$ \\
\hline Mining & Study addressed effects of mining on species habitat, populations, or individuals. \\
\hline Ex-urban development & $\begin{array}{l}\text { Study addressed effects of ex-urban development on species habitat, populations, or } \\
\text { individuals. }\end{array}$ \\
\hline Infrastructure & $\begin{array}{l}\text { Study addressed effects of various other infrastructure elements (for example, roads, } \\
\text { pipelines, powerlines, cell towers) on species habitat, predators, populations, or } \\
\text { individuals. }\end{array}$ \\
\hline Agricultural conversion & $\begin{array}{l}\text { Study addressed effects of agriculture or agricultural conversion on species habitat, } \\
\text { populations, or individuals. }\end{array}$ \\
\hline Weather and climate & $\begin{array}{l}\text { Study addressed effects of weather or climate on species habitat, populations, or } \\
\text { individuals. }\end{array}$ \\
\hline Other & $\begin{array}{l}\text { Study is focused on another aspect of species biology, ecology, or management not } \\
\text { listed above. }\end{array}$ \\
\hline
\end{tabular}

As a first step in developing the article/report summaries, the team of scientists independently read, summarized, and identified management topics for a small number of articles. Results were compared and questions resolved to help foster consistency in the article/report summaries and the categorization of management topics for the document.

\section{Results and Conclusions}

The 2018 literature search produced 996 products that recognized "greater sage-grouse" in the title, keywords, abstract, or manuscript text. Applying our additional criteria to remove duplicates, non-peer-reviewed products, and articles/reports that did not represent original, complete studies on GRSG resulted in a final list of 169 journal articles and formal technical reports focused on GRSG research for inclusion in that document ( 2 of these products are published corrections to journal articles). For this updated report, we conducted a similar 
literature search for documents published between January 7, 2018 and October 2, 2019 which returned 840 products. This was subsequently reduced to 69 products after applying additional filter criteria. These newly added products are designated by "*2019 Update*" in the annotated bibliography that follows. Most products ( 88 percent) summarized address multiple management topics (table 3). For each product, we include the full citation, DOI, summary, and key management topics addressed. The online version of this bibliography (https://apps.usgs.gov/gsgbib/index.php) is searchable by topic and location and includes links to all original publications.

Table 3. Number of products addressing each management topic. Counts and proportions include previously and newly summarized products for a total of 237 products.

\begin{tabular}{|c|c|c|}
\hline Management topic & $\begin{array}{l}\text { Number of products that } \\
\text { address topic }\end{array}$ & $\begin{array}{l}\text { Proportion of products } \\
\text { that address topic }\end{array}$ \\
\hline Survival & 48 & 0.20 \\
\hline Behavior or demographics & 113 & 0.48 \\
\hline Population estimates or targets & 47 & 0.20 \\
\hline Captive breeding & 4 & 0.02 \\
\hline Translocation & 14 & 0.06 \\
\hline Genetics & 18 & 0.08 \\
\hline Broad-scale habitat characteristics & 98 & 0.41 \\
\hline Site-scale habitat characteristics & 86 & 0.36 \\
\hline Habitat selection & 74 & 0.31 \\
\hline Habitat restoration or reclamation & 45 & 0.19 \\
\hline New geospatial data & 65 & 0.27 \\
\hline Human dimensions or economics & 22 & 0.09 \\
\hline Effect distances or spatial scale & 63 & 0.27 \\
\hline Hunting & 8 & 0.03 \\
\hline Recreation & 6 & 0.03 \\
\hline Predators or predator control & 24 & 0.10 \\
\hline Fire or fuel breaks & 29 & 0.12 \\
\hline Nonnative invasive plants & 26 & 0.11 \\
\hline Sagebrush removal & 18 & 0.08 \\
\hline Conifer expansion & 36 & 0.15 \\
\hline Wild horses and burros & 5 & 0.02 \\
\hline Herbivory/grazing & 20 & 0.08 \\
\hline Fences & 8 & 0.03 \\
\hline Other range management structures & 6 & 0.03 \\
\hline Energy development & 36 & 0.15 \\
\hline Mining & 11 & 0.05 \\
\hline
\end{tabular}




\begin{tabular}{lcc}
\hline Management topic & $\begin{array}{c}\text { Number of products that } \\
\text { address topic }\end{array}$ & $\begin{array}{c}\text { Proportion of products } \\
\text { that address topic }\end{array}$ \\
\hline Ex-urban development & 15 & 0.06 \\
Infrastructure & 44 & 0.19 \\
Agricultural conversion & 24 & 0.10 \\
Weather and climate & 48 & 0.20 \\
Other & 13 & 0.05 \\
\hline
\end{tabular}

A substantial body of literature has been compiled on research explicitly related to the conservation, management, monitoring, and assessment of GRSG. These studies may inform planning and management actions that seek to balance conservation, economic, and social objectives and manage diverse resource uses and values across the western United States.

\section{Review Process}

The review process for this product included a request for input on each summary from one or more authors of the original peer-reviewed article or report and a formal review of the entire document by three independent reviewers for the original content and two independent reviews for the updated content, and the USGS Bureau Approving Official. This process is consistent with USGS Fundamental Science Practices (Fundamental Science Practices Advisory Committee, 2011).

\section{Acknowledgments}

We thank USGS Library staff members Emily Wild for providing helpful guidance and for conducting the initial literature search and Erica Patterson for conducting follow-up searches. Robert Arkle led the 2019-2020 update to the original document. Sanjay Advani and Justin Welty conducted literature searches for this updated document. Michelle Jeffries, Jessica Carnes, and Kelly Mazur also assisted with updates to this document. We thank Tim Kern and Gail Montgomery for developing the web interface.

We thank the many authors of the articles and reports summarized in this annotated bibliography for providing input on the draft summaries of their works, including Jonathan Bates, Jeremy Baumgardt, Jeffrey Beck, Lorien Belton, Sara Bombaci, Stephen Boyte, Clait Braun, Brian Cade, Jason Carlisle, Michael Casazza, Danny Caudill, Jeanne Chambers, Peter Coates, Michael Conover, Megan Creutzburg, Michele Crist, Todd Cross, Michael Curran, David Dahlgren, Dawn Davis, Karin Decker, Jonathan Dinkins, Patrick Donnelly, Jonathan Dudko, Kasten Dumroese, David Edmunds, Lisa Ellsworth, Shahla Farzan, Brad Fedy, Lee Foster, Aleshia Fremgen, Marcella Fremgen, Scott Gamo, Steven Garman, Daniel Gibson, Adam Green, Andrew Gregory, Michael Guttery, Erica Hansen, Julie Heinrichs, E.B. Henderson, Jennifer Hess, Matthew Holloran, Colin Homer, Josh Jahner, Thomas Jones, Lara Juliusson, Christopher Kirol, Rebecca Koch, Michel Kohl, Kevin Kohl, Urs Kreuter, T. Luna, Jeremy Maestas, Steven Mathews, Rebecca McCaffery, Terry Messmer, Joshua Millspaugh, Adrian Monroe, Rebecca Newton, Michael O'Donnell, Elizabeth Orning, Sara Oyler-McCance, Kyle Palmquist, Victoria Pennington, Anna Perry, D'Jeane Peters, Steven Petersen, Maurice Pitesky, Aaron Pratt, Janet Rachlow, Rob Ramey, Jason Reinhardt, Mark Ricca, Mindy Rice, Jeffrey 
Row, Mary Roland, Sean Schroff, John Severson, Lisa Shipley, Andrew Shirk, Jennifer Smith, Joseph Smith, Kurt Smith, Kourtney Stonehouse, Jason Tack, D.T. Taylor, Jennifer Timmer, Lucas Ward, Stephen Webb, Katherine Wollstein, and Khodabakhsh Zabihi. We are very grateful to Anna Chalfoun, Heather McPherron, and David Pyke for conducting independent peer reviews of the original document and to Susan Kemp and Ian Dwight for providing independent reviews of the updated content.

Funding for this work was provided by the BLM and the USGS Ecosystems Mission Area.

\section{References Cited}

Bureau of Land Management, 2015a, Nevada and Northeastern California greater sage-grouse approved resource management plan amendment, attachment 2 of USDI 2015 Record of decision and approved resource management plan amendments for the Great Basin region, including the greater sage-grouse sub-regions of Idaho and southwestern Montana, Nevada and Northeastern California, Oregon, and Utah: Bureau of Land Management, variously paged, accessed December 19, 2017, at https://eplanning.blm.gov/epl-frontoffice/projects/lup/21152/63235/68484/NVCA_Approved_RMP_Amendment.pdf.

Bureau of Land Management, 2015b, Record of decision and approved resource management plan amendments for the Rocky Mountain region, including the greater sage-grouse subregions of Lewiston, North Dakota, Northwest Colorado, and Wyoming, and the approved resource management plans for Billings, Buffalo, Cody, HiLine, Miles City, Pompeys Pillar National Monument, South Dakota, and Worland: Bureau of Land Management, variously paged, accessed January 13, 2018, at https://eplanning.blm.gov/epl-frontoffice/projects/lup/36511/63222/68471/RM_ROD_9.21.15_508_lowres.pdf.

Carter, S.K., Manier, D.J., Arkle, R.S., Johnston, A.․․, Phillips, S.L.L., Hanser, S.E., and Bowen, Z.H., 2018, Annotated bibliography of scientific research on greater sage-grouse published since January 2015: U.S. Geological Survey Open-File Report 2018-1008, 183 p., https://doi.org/10.3133/ofr20181008.

Connelly, J.W., Reese, K.P., Fischer, R.A., and Wakkinen, W.L., 2000, Response of a sage grouse breeding population to fire in southeastern Idaho: Wildlife Society Bulletin, v. 28, p. 90-96.

Fundamental Science Practices Advisory Committee, 2011, U.S. Geological Survey

Fundamental Science Practices: U.S. Geological Survey Circular 1367, 8 p.

Knick, S.T., and Connelly, J.W., eds., Greater sage-grouse-Ecology and conservation of a landscape species and its habitats: Berkeley, Calif., University of California Press, Studies in Avian Biology 38, 664 p.

Schroeder, M.A., Aldridge, C.L., Apa, A.D., Bohne, J.R., Braun, C.E., Bunnell, S.D., Connelly, J.W., Deibert, P.A., Gardner, S.C., Hilliard, M.A., Kobriger, G.D., McAdam, S.M., McCarthy, C.W., McCarthy, J.J., Mitchell, D.L., Rickerson, E.V., and Stiver, S.J., 2004, Distribution of sage-grouse in North America: Condor, v. 106, p. 363-376.

U.S. Department of the Interior, 2015, An integrated rangeland fire management strategy: U.S. Department of the Interior, 82 p., accessed December 19, 2017, at https://www.forestsandrangelands.gov/rangeland/documents/IntegratedRangelandFireManage mentStrategy_FinalReportMay2015.pdf. 
U.S. Department of the Interior, 2017, Report in response to secretarial order 3353: U.S. Department of the Interior, 15 p., accessed December 19, 2017, at https://www.eenews.net/assets/2017/08/07/document_gw_08.pdf.

U.S. Fish and Wildlife Service, 2013, Greater sage-grouse (Centrocercus urophasianus) conservation objectives-Final report: U.S. Fish and Wildlife Service, 92 p., accessed December 19, 2017, at https://www.fws.gov/greatersagegrouse/documents/COT-Report-withDear-Interested-Reader-Letter.pdf.

U.S. Fish and Wildlife Service, 2015, Endangered and threatened wildlife and plants-12-month finding on a petition to list greater sage-grouse (Centrocercus urophasianus) as an endangered or threatened species: Federal Register, v. 80, no. 191, p. 59858-59942, accessed December 19, 2017, at https://www.gpo.gov/fdsys/pkg/FR-2015-10-02/pdf/2015-24292.pdf.

U.S. Geological Survey, 2014a, Greater sage-grouse 2015 USFWS status review current range: U.S. Geological Survey, ScienceBase, accessed November 21, 2017, at https://www.sciencebase.gov/catalog/item/56f96693e4b0a6037df06034.

U.S. Geological Survey, 2014b, Greater sage-grouse 2015 USFWS status review management zones: U.S. Geological Survey, ScienceBase, accessed November 21, 2017, at https://www.sciencebase.gov/catalog/item/56f96b30e4b0a6037df06216.

U.S. Geological Survey, 2016, GRSG updated historic range with WY "WyomingHistoricRange2014.shp" data: U.S. Geological Survey, ScienceBase, accessed November 21, 2017, at https://www.sciencebase.gov/catalog/item/57e415cce4b090825005b6ac.

Western Association of Fish and Wildlife Agencies, 2015, Greater sage-grouse population trends-An analysis of lek count databases 1965-2015: Cheyenne, Wyo., Western Association of Fish and Wildlife Agencies, 54 p., accessed December 19, 2017, at http://www.wafwa.org/Documents\%20and\%20Settings/37/Site\%20Documents/News/Lek\%20 Trend\%20Analysis\%20final\%208-14-15.pdf. 


\section{Annotated Bibliography}




\section{Apa, A.D., Thompson, T.R., and Reese, K.P., 2017, Juvenile greater sage-grouse survival, movements, and recruitment in Colorado: Journal of Wildlife Management, v. 81, no. 4, p. 652-668.}

DOI: https://doi.org/10.1002/jwmg.21230

Background: Juvenile survival of GRSG is an important component of GRSG demographics, but available information is limited. GRSG populations have become isolated in some locations and may be augmented through reintroduction of captive-reared chicks. Information on juvenile survival of captive-reared chicks can inform such efforts.

Objectives: The authors sought (1) to estimate and evaluate factors affecting the survival of juvenile GRSG, (2) to compare adult and juvenile survival, (3) to determine recruitment rates, (4) to identify movement from fall to winter ranges, and (5) to compare survival of wild and domestically hatched chicks.

Methods: The authors used radio telemetry to monitor movement and survival of 60-65 adult and 183 juvenile GRSG from September until March at two study sites from 2005 to 2008. Both wild chicks and domestically hatched chicks that had been introduced into wild broods were monitored. Survival was evaluated for influence of study area, year, body mass at two ages, day of hatch, and whether the chicks were wild or domestically hatched.

Location: Colorado; MZ II

Findings: In juvenile GRSG, female survival rates were greater than male survival rates, with most mortality occurring in fall. Survival rates of wild and domestically hatched chicks were similar. Survival of juveniles was lower than adults during fall and spring but was comparable over winter months. Most surviving juveniles recruited into their natal population and did not migrate to other populations. Survival and recruitment rates and movement distances varied by study site.

Implications: Juvenile GRSG are vulnerable in the fall, when broods disassociate. Lower survival of juveniles compared to adults in fall and spring may be related to greater vulnerability of juveniles to predation during these time periods. Domestic hatching followed by introduction of young chicks into existing wild broods was deemed successful because survival rates of these birds were comparable to wild-hatched birds. However, observed recruitment rates may not be sufficient to replace adult mortality in these two populations.

Topics: behavior or demographics, captive breeding, survival 


\section{Balzotti, C.S., Kitchen, S.G., and McCarthy, C., 2016, Beyond the single species climate envelope-A multifaceted approach to mapping climate change vulnerability: Ecosphere, v. 7, no. 9, article e01444, 23 p.}

DOI: https://doi.org/10.1002/ecs2.1444

Background: Incorporating climate-change projections into species and land management conservation is challenging. Landscape-level vulnerability assessments may help managers consider potential effects of climate on habitat conditions that affect GRSG. Spatial data and maps quantify assessments and offer visualizations important to interpreting them and guiding management.

Objectives: Project objectives were (1) to assess vulnerability of GRSG habitat to climate change and (2) to map vulnerability of GRSG habitat to climate change at a relevant scale to inform planning and habitat management for GRSG.

Methods: The authors developed climate envelope models for sagebrush, pinyon pine, juniper, and cheatgrass to inform climate-change vulnerability assessments conducted at a subregional scale and at a local scale (defined by boundaries of Priority Areas for Conservation [PACs]). Vulnerability assessments also considered drought (both scales) and fire, conifer encroachment, risk of invasive annual grasses, and human modification (local scale only). Two commonly used indices of climate-change vulnerability were calculated. Comparisons were made between mean contemporary (1961-1990) and projected future (2041-2070) conditions. An ensemble of 23 future climate models and a moderate emissions scenario were used to model potential future conditions.

\section{Location: Utah, Nevada; MZ III}

Findings: Climate envelope models indicated a loss of suitable climate for Wyoming big sagebrush across much of the subregion. Multiyear droughts have occurred in all PACs in the subregion over the last century. Vulnerability to climate change was high according to both indices at both spatial scales. Local-level evaluations indicated higher risk in the drier Sheeprock PAC compared to the Strawberry PAC because of potential loss of sagebrush from climate change and increasing potential for conifer expansion and cheatgrass.

Implications: Periodic drought, increasing conifer cover, and invasion by cheatgrass were projected to affect sagebrush ecosystems across the region and within local evaluation areas. These changes resulted in projected vulnerability of GRSG. At the local level, landscape connections between the Strawberry PAC and other GRSG populations contributed to greater projected resilience of GRSG populations there. The authors presented a model framework that incorporates multiple stressors to assess potential future habitat vulnerability, which can assist decision makers in determining species vulnerability and inform management plans.

Topics: conifer expansion, energy development, fire or fuel breaks, new geospatial data, nonnative invasive plants, weather and climate 
*2019 Update* Bates, J.D., and Davies, K.W., 2019, Characteristics of intact Wyoming big sagebrush associations in southeastern Oregon: Rangeland Ecology \& Management, v. 72 , no. 1 , p. 36-46.

DOI: $\underline{\text { https://doi.org/10.1016/j.rama.2018.07.015 }}$

Background: The Wyoming big sagebrush vegetation community, or alliance, comprises a large proportion of the Intermountain West. However, the diversity or heterogeneity within this community type, and how this diversity relates to GRSG habitat requirements, is poorly understood.

Objectives: The authors' goal was to describe variability in vegetation characteristics within the Wyoming big sagebrush alliance in order to group areas based on dominant perennial grass species.

Methods: Forty-eight Wyoming big sagebrush communities were sampled annually for 10 years in southeastern Oregon. Canopy cover, density, richness, and yield were quantified.

Location: Oregon; MZ IV, MZ V

Findings: The authors identified six major Wyoming big sagebrush associations, defined by dominant perennial bunchgrass species, in southeast Oregon. Perennial grass and forb cover were greatest in bluebunch wheatgrass and Idaho fescue associations, whereas sagebrush cover was greatest in Thurber's needlegrass associations. At the plot or stand level, most locations do not meet breeding habitat requirements for GRSG and only meet requirements for other life stages of GRSG about half of the time.

Implications: These findings could be used to help develop and implement management guidelines and actions aimed at preserving or restoring intact Wyoming big sagebrush communities.

Topics: site-scale habitat characteristics 


\section{Bates, J.D., Davies, K.W., Hulet, A., Miller, R.F., and Roundy, B., 2017, Sage grouse groceries-Forb response to piñon-juniper treatments: Rangeland Ecology and Management, v. 70, no. 1, p. 106-115.}

DOI: https://doi.org/10.1016/j.rama.2016.04.004

Background: Pinyon pine and juniper woodlands have expanded substantially in the last 150 years, with most of that expansion occurring in sagebrush steppe ecosystems. Management treatments to control woodland expansion have been implemented since the 1950s with goals of improving watershed function, increasing livestock forage, and restoring wildlife habitat. GRSG are sensitive to the presence of conifers and may avoid areas and abandon leks as tree cover increases. Increased conifer cover has been associated with decreases in sagebrush, grasses, and forbs, which provide food and cover for GRSG.

Objectives: Authors analyzed datasets from previous and ongoing experimental conifer treatment studies to compare how forb cover was affected by (1) fire treatments (fuel reduction, prescribed fire) and mechanical treatments (clear cutting, mastication) compared to control sites and (2) treatment in different phases of conifer expansion.

Methods: The authors analyzed forb cover (including annual and perennial forbs known to be consumed by GRSG) for 4-8 years following treatment at 18 sites across the northern Great Basin. Sites included multiple woodland types (western juniper, singleleaf pinyon and Utah juniper, Utah juniper, and Utah juniper and Colorado pinyon) and all woodland expansion phases. Fuel reduction treatments consisted of burning cut trees and slash in the winter or spring with minimal other disturbance to the site.

Location: California, southwestern Idaho, Nevada, eastern Oregon, Utah; MZ IV, MZ V

Findings: Treatment of pinyon and juniper woodlands produced variable responses in perennial and annual forbs that are forage for GRSG. Cover of perennial forbs consumed by GRSG was greater in most, but not all, sites after treatment, and responses were similar among treatment methods. Annual forbs consumed by GRSG benefited most from prescribed fire, with cover being higher in most sites where prescribed fire treatments were applied compared to both control sites and sites with other treatments. However, though annual forb cover was dominated by native species in the western juniper sites, it was dominated by nonnative species in the Wyoming big sagebrush sites. Treatments applied to woodlands in early phases of expansion tended to produce a greater forb response. Differences among sites, including vegetation composition and site potential, influenced conditions after treatment.

Implications: Patchy fires may provide habitat benefits for GRSG, but application requires caution so that the fires do not become too large and are not applied in inappropriate habitats. Mechanical and fuel-reduction treatments applied in the early phases of woodland expansion may achieve benefits for forbs while also retaining the sagebrush structure of the system, but they will require follow-up treatments. All treatments should target those seasonal habitats in which forb availability may be limiting for GRSG and site potential is high. 
Topics: conifer expansion, fire or fuel breaks, habitat restoration or reclamation, sagebrush removal, site-scale habitat characteristics 


\section{Baumgardt, J.A., Reese, K.P., Connelly, J.W., and Garton, E.O., 2017, Visibility bias for sage- grouse lek counts: Wildlife Society Bulletin, v. 41, no. 3, p. 461-470.}

DOI: https://doi.org/10.1002/wsb.800

Background: Inventory and monitoring of GRSG populations depend on count surveys of birds when they are congregated at leks for mating. Accurate monitoring of population dynamics through use of lek counts requires a clear understanding of the accuracy of such counts.

Objectives: The study objective was to assess the effect of observation conditions (light conditions, grouse behavior, lek characteristics, and observer experience) on the observation bias of lek counts.

Methods: The authors conducted 73 counts at 11 GRSG leks during 2007-2009; they counted from trucks using standard methods for comparison with independent counts conducted from blinds placed 3-20 meters from the lek. To determine reliability of standard techniques, they analyzed variability in standard lek counts caused by light conditions, visual obstruction, observer experience, date, and weather conditions. A sightability model was used to compare extended observations to independent counts.

Location: south-central Idaho; MZ IV

Findings: Naive visibility, described as the count conducted from a truck while using a spotting scope from 0.5 hours before to 1.5 hours after sunrise, was 79 percent of the total number of GRSG observed from blinds on leks. Hen presence and light shining on the lek decreased visibility bias, and bias increased later in the morning. The effect of cloud cover varied with time of day.

Implications: Although observability of GRSG is high, some bias (or error) in typical lek count methods may occur. The authors provided methods for correcting visibility bias in future lek counts to improve accuracy of estimates of GRSG population components. The authors cautioned that visibility bias may increase with time after sunrise because male GRSG became less active. They suggested that leks be counted at least four times per season and only from 0.5 hours before to 1 hour after sunrise; they also suggested that ancillary information be collected to allow counts to be adjusted for visibility bias.

Topics: population estimates or targets, weather and climate 


\section{Baxter, J.J., Baxter, R.J., Dahlgren, D.K., and Larsen, R.T., 2017, Resource selection by greater sage-grouse reveals preference for mechanically-altered habitats: Rangeland Ecology and Management, v. 70, no. 4, p. 493-503.}

DOI: https://doi.org/10.1016/j.rama.2017.01.007

Background: Human activities have contributed strongly to the decrease in the area of sagebrush ecosystems in western North America, and sagebrush-obligate species are particularly sensitive to sagebrush ecosystem loss and alteration. Management treatments intended to improve GRSG habitat conditions are commonly implemented, but benefits to the species are often unknown.

Objectives: Study objectives were to evaluate the effectiveness of mechanical conifer removal treatments by quantifying differences in (1) shrub and herbaceous cover and (2) GRSG broodrearing habitat selection before and after areas of mountain big sagebrush were treated.

Methods: Dense patches of sagebrush were mechanically treated annually by using either a chain harrow or brushhog mower in treatment sites. Vegetation was measured at random locations before and after treatment. The authors used telemetry to monitor locations of 72 female GRSG from 1998 to 2016 and used resource selection functions to quantify brood-rearing habitat selection. The models also included topographic variables quantified at multiple spatial scales, distances to the nearest anthropogenic features (roads, power lines, structures), and land cover variables.

\section{Location: Utah; MZ III}

Findings: Treatments significantly reduced shrub crown area, height, and cover. Grass species richness was higher after treatment, and forb cover was unchanged. GRSG selected areas that were far from trees, paved roads, and power lines; at high elevations; within and near edges of treatments; and gently sloped.

Implications: An increase in forb cover after treatment was expected but not observed, potentially because of lower annual precipitation levels after treatment, competition with grasses, or a lag effect of treatment. A significant increase in use of habitat in and near (within 90 meters) treated mountain big sagebrush sites by brooding GRSG suggests that such treatments may be beneficial to GRSG. However, survival and recruitment were not assessed, making it unclear whether the altered habitat selection patterns observed here ultimately benefited the population. Treatments, when implemented, should target specific areas of dense sagebrush and avoid GRSG nesting and wintering habitat.

Topics: effect distances or spatial scale, habitat restoration or reclamation, habitat selection, infrastructure (roads, pipelines, powerlines, cell towers), sagebrush removal, site-scale habitat characteristics 


\section{Belton, L.R., Frey, S.N., and Dahlgren, D.K. 2017, Participatory research in sage-grouse local working groups-Case studies from Utah: Human-Wildlife Interactions, v. 11, no. 3, p. 287-301.}

DOI: https://doi.org/10.26077/w2zw-za85

Background: Local working groups were created in many western states to help ensure that a broad range of stakeholders could be involved in conversations and efforts to manage and conserve GRSG. Local working groups are often involved in participatory research that can foster collaborative, science-based species management.

Objectives: The authors' objective was to use four case studies to describe local working groups and their role in participatory research and subsequent conservation and management efforts for GRSG.

Methods: The authors described four local working groups from across the state based on the experiences of three local working group facilitators.

Location: Utah; MZ III

Findings: Participants in the working groups were diverse, including local agricultural producers and coal mine operators, county leaders, military installations, Federal and State scientists and managers, Native American tribal members, and many others. Members of the working groups helped identify research questions, conduct experiments, collect data, and resolve challenges. Topics addressed in these participatory research efforts were diverse, including grazing, GRSG translocation, and the effectiveness of coal mine mitigation actions. Funding for participatory research was also diverse and included Federal, State, county, and local sources (such as local grazing associations and pipeline mitigation funds). Local working groups regularly discussed results as projects progressed and used those results to inform subsequent National Environmental Policy Act analyses, mitigation actions, and management actions such as conifer removal, sagebrush restoration, and grazing strategies.

Implications: Participatory research conducted with local working groups has informed planning efforts at Federal and State levels, as well as local plans and actions. Such research can build trust in science information used to develop plans and can make subsequent management choices more acceptable to stakeholders.

Topics: herbivory/grazing, human dimensions or economics, mining, translocation 


\section{Bentley Brymer, A.L., Holbrook, J.D., Niemeyer, R.J., Suazo, A.A., Wulfhorst, J.D., Vierling, K.T., Newingham, B.A., Link, T.E., and Rachlow, J.L., 2016, A social-ecological impact assessment for public lands management-Application of a conceptual and methodological framework: Ecology and Society, v. 21, no. 3, article 9, 22 p.}

DOI: https://doi.org/10.5751/ES-08569-210309

Background: Understanding social effects of conservation and management is an important part of an Environmental Impact Assessment (EIA). This project was unique in its focus on the integration of social and ecological concepts to facilitate stakeholders' deliberation of proposed management alternatives and their potential effects.

Objectives: This project sought (1) to develop an integrated framework for planning that included ecosystem services and sociopolitical processes and (2) to create a process that expands planning to include affected people in discussions while fulfilling National Environmental Policy Act requirements.

Methods: The authors developed and tested methods for stakeholder participation in EIAs by using the Bureau of Land Management's planning process for conifer removal projects that benefit GRSG habitat as a test case. Participants included 24 people representing Federal, State, and local entities; nongovernmental organizations; and private citizens. A combination of questionnaires, deliberation, and participatory mapping in workshop settings was used to gather perceptions of potential environmental changes and effects.

Location: Idaho; MZ IV

Findings: By emphasizing a conceptual framework that integrated social and ecological processes, the authors demonstrated how stakeholders perceive and understand environmental processes, management interventions, and change to be interdependent, and that these processes may be integrated to understand complex perspectives and develop comprehensive plans.

Implications: Integrating social and ecological processes during the EIA process led to greater documentation of highly variable perspectives and points of consensus. Spatial representation of social and ecological values and place meanings provided important insights. Improving the role of a wide range of stakeholders provided a more holistic view of plans and effects and resulted in the potential for broader support of management plans.

Topics: conifer expansion, human dimensions or economics 


\section{Blomberg, E.J., 2015, The influence of harvest timing on greater sage-grouse survival-A cautionary perspective: Journal of Wildlife Management, v. 79, no. 5, p. 695-703.}

DOI: https://doi.org/10.1002/jwmg.887

Background: Hunting of GRSG occurred in nine states in the western United States in fall 2014. Hunting generally occurs during short fall seasons with conservative bag limits. Effects of harvest on populations vary depending on the ability of the species to compensate, partially or completely, for lost individuals with increased survival rates. Shifting GRSG hunting seasons to later in the year has been recommended to reduce harvest of juveniles and females.

Objectives: Study objectives were (1) to test the role of delayed harvest on GRSG mortality using compensatory and additive mortality models and (2) to describe potential effects of delayed harvest on the population.

Methods: The author used harvest and survival models parameterized using published data to test potential effects of changes in harvest timing on relations between harvest and population response. Because it was not known whether harvest mortality was compensatory or additive in GRSG, the author tested both mortality scenarios.

Location: Nevada; MZ III

Findings: Published monthly survival estimates used in models indicated higher mortality rates in fall for both juveniles and adults, likely the result of predation, which appeared to be sustained with or without hunter effects. Model results indicated that moving hunting seasons to later in the year could have negative population consequences under either additive or compensatory mortality scenarios.

Implications: Optimal harvest strategies remove individuals with low reproductive value before other sources of mortality are likely to occur. Other studies have found GRSG mortality to be highest in the fall in some parts of its range. Earlier harvest seasons allow the greatest potential for harvest mortality to be compensatory. If mortality is additive, effects of a later harvest season may be minimized if harvest quotas are reduced. The author concluded that timing of mortality, coupled with potential effects indicated by compensatory and additive mortality models, suggests that moving harvest to later in the year will not benefit GRSG populations and may have unintended negative consequences.

Topics: hunting, survival 


\section{Blomberg, E.J., Gibson, D., Atamian, M.T., and Sedinger, J.S., 2017, Variable drivers of primary versus secondary nesting-Density-dependence and drought effects on greater sage-grouse: Journal of Avian Biology, v. 48, no. 6, p. 827-836.}

DOI: https://doi.org/10.1111/jav.00988

Background: Reproductive success is important for GRSG recruitment; however, reproductive costs in the form of adult mortality may negatively affect population numbers. The effect of environmental conditions on individual fitness is often unpredictable but has important implications for population growth.

Objectives: Based on sources of variability in nesting behavior, the authors sought to determine the relation between the probability of a female GRSG initiating a nest and (1) environmental conditions (drought), (2) density dependence, and (3) the age and condition of the hen.

Methods: The authors used radio telemetry data from 287 female GRSG over a 10-year period to track primary nesting and secondary (given the failure of the first nest) nesting behavior at 421 nests. The authors modeled rates of primary and secondary nest initiation in relation to annual precipitation, annual estimates of male GRSG abundance derived from mark-recapture estimates developed in a previously published study, and female age and condition.

\section{Location: Nevada; MZ III}

Findings: Initiation of a first nest was positively associated with hens of intermediate age (approximately 2-4 years) and negatively associated with increasing numbers of male GRSG counted at leks, but it was not affected by the amount of precipitation. Probability of a second nesting attempt, given the failure of the first nest, was more variable and considerably lower than first-nest attempts; it was negatively associated with high population densities and positively associated with precipitation and hen condition.

Implications: Dynamic environmental conditions, age, and body condition can affect GRSG reproductive effort. The authors suggest that lower and more variable probabilities of secondnest initiation reflect a balancing of individual mortality risk with likely reproductive gain, as well as the lower reproductive reward reaped from broods that are hatched later in the year. Density-dependent effects on the probability of nest initiation likely result from limited resource availability when GRSG abundance is high, possibly in high-quality forage availability prior to the breeding season. Effects of precipitation on nesting rates might be more apparent over longer time scales or periods.

Topics: behavior or demographics, population estimates or targets, weather and climate 


\section{Bombaci, S., and Pejchar, L., 2016, Consequences of pinyon and juniper woodland reduction for wildlife in North America: Forest Ecology and Management, v. 365, p. 34-50.}

DOI: https://doi.org/10.1016/j.foreco.2016.01.018

Background: Conifer removal has become a common management action to restore wildlife habitat in shrublands and grasslands of western North America because of the expansion of pinyon pine and juniper trees into those systems. An understanding of the wildlife response to conifer removal treatments is needed to understand their potential costs and benefits.

Objectives: The authors summarized the history of conifer reduction treatments and described known wildlife species associations with pinyon-juniper woodlands. They also reviewed scientific literature to answer two questions: (1) what are the effects of conifer removal treatments on wildlife, and (2) how do these effects vary among different groups of wildlife and across spatial and temporal scales.

Methods: The authors conducted a literature search using Web of Science and Google Scholar and conducted a meta-analysis using data from 19 publications that quantified effects of conifer removal treatments on wildlife.

\section{Location: western North America}

Findings: The authors identified no consistent trend in the effects of woodland reduction treatments on wildlife. Small mammals tended to respond positively to thinning but neutrally to mechanical removal or prescribed fire. However, grassland small mammal species only responded positively to complete removal of trees. Most studies found neutral or negative responses of ungulates to treatments. Deer and elk utilized increased forage in some seasons, but total removal of trees over large areas did not appear beneficial. Most thinning and burning studies documented non-significant effects of treatment on birds, but complete mechanical removal of trees generally resulted in negative effects. GRSG is one of only a few sagebrush bird species for which studies have documented positive responses to treatment. However, effects of tree removal on most sagebrush birds have not been well studied, especially over longer temporal scales that may be needed to see positive responses. Invertebrate responses to treatment were variable among species but mostly non-significant.

Implications: There is a need for further study of the effects of woodland reduction treatment on many taxa, including invertebrates, reptiles, amphibians, bats, and large predators. Some new treatment methods are being adopted (such as roller-chopping), but their effects in relation to more traditional approaches are unclear. Long-term and large-scale responses are poorly understood as well, and an understanding of such effects may be particularly important for sagebrush-obligate species. There is also a geographic imbalance in the number of existing studies, with fewer studies noted from Idaho, Wyoming, and California in particular.

Topics: conifer expansion, habitat restoration or reclamation 


\section{Boyd C.S., Kerby, J.D., Svejcar, T.J., Bates, J.D., Johnson, D.D. and Davies, K.W., 2017, The sage-grouse habitat mortgage-Effective conifer management in space and time: Rangeland Ecology and Management, v. 70, no. 1, p. 141-148.}

DOI: https://doi.org/10.1016/j.rama.2016.08.012

Background: The effectiveness of management actions taken to restore habitat for wildlife may vary in space and time, and research studies quantifying effectiveness are often conducted over a much shorter time frame than habitat restoration actions are likely to be effective. There is a need to better understand the different ecological and financial benefits and costs associated with different restoration actions, such as the use of fire treatments compared to mechanical treatments to control conifer expansion into sagebrush systems to restore habitat for GRSG.

Objectives: In this article, the authors sought (1) to examine long- and short-term GRSG habitat needs, (2) to develop a metric that includes space and time to represent the value of management actions, and (3) to provide guidance on how to more optimally design habitat treatments.

Methods: The authors developed an approach for assessing spatial and temporal effects of management actions to control conifer expansion. They also created a metric (conservation volume) that enables consideration of the short- and long-term costs and benefits of different treatment methods beyond simply reporting acres treated without consideration of durability.

Location: California, Idaho, Nevada, Oregon, Utah; MZ IV, MZ V

Findings: The authors described conservation volume as a product of the area to be conserved and the desired time period of effective conservation. Treatments can also be considered in terms of the time period over which they are likely to be effective. Fire may delay the return of conifers longer than cutting, but it incurs the often unacceptable short-term conservation cost of loss of sagebrush. Mechanical removal of conifers retains sagebrush, but it needs to be repeated more often to prevent woodland conversion. Managing for biological thresholds (such as retention of a minimum area of sagebrush) can help clarify acceptable ecological costs. Together with consideration of financial costs, the example illustrated that neither approach alone is likely to be optimal for managing the threat of conifer expansion to GRSG habitat over the long term.

Implications: Although greatly simplified from the complexity of treatment options, ecological contexts, and responses observed in the real world, the hypothetical example of long-term management demonstrated the value of considering financial and ecological costs and benefits and their variation in space and time. This approach is described for conifer control in GRSG habitat, but it could be used more broadly to inform the application of management actions over ecologically relevant spatial and temporal scales.

Topics: conifer expansion, fire or fuel breaks, habitat restoration or reclamation, sagebrush removal 


\section{Boyte, S.P., Wylie, B.K., and Major, D.J., 2016, Cheatgrass percent cover change- Comparing recent estimates to climate change-driven predictions in the northern Great Basin: Rangeland Ecology and Management, v. 69, no. 4, p. 265-279.}

DOI: https://doi.org/10.1016/j.rama.2016.03.002

Background: Cheatgrass is the most problematic invasive plant in the northern Great Basin, currently dominating about 7 percent of its land area. The presence of cheatgrass contributes to altered fire regimes that threaten GRSG habitat conditions in the sagebrush ecosystem. Future climate changes in the region may alter cheatgrass conditions and dynamics.

Objectives: This study sought (1) to map the current cover of cheatgrass in the northern Great Basin, (2) to identify areas where cheatgrass cover is likely to change, and (3) to describe the potential future magnitude of change for years 2050 and 2070.

Methods: Researchers modeled cheatgrass cover in shrublands and grasslands of the northern Great Basin based on phenological signatures from remote sensing, topography, weather, and soil patterns. The dependent variable in models was remotely sensed estimates of cheatgrass percent cover from 2001 and 2006, trained with field measurements of cheatgrass percent cover. Climate projections were based on scenarios from the Intergovernmental Panel on Climate Change for 2050 and 2070.

Location: northeastern California, Idaho, Nevada, Oregon, northwestern Utah; MZ III, MZ IV, MZ V

Findings: Comparison of actual and expected cheatgrass cover indicated good model accuracy. Cheatgrass cover during 2000-2010 was widely variable across the region and over time; average cover ranged from 0 to 87 percent. Only 11 percent of the region was classified as having moderate to high susceptibility to increased cheatgrass cover. Several GRSG Priority Areas for Conservation were within this area of higher susceptibility, but overall susceptibility of these areas was slightly lower than for the region as a whole. Future climate projections indicated warmer conditions, with less precipitation during some periods and wetter conditions in winter and March. Cheatgrass cover was projected to be stable across most of the region, with increases in percent cover projected across 14 and 18 percent of the land area by 2050 and 2070, respectively.

Implications: Cheatgrass cover is projected to increase in the northern Great Basin and become more spatially variable. Most projected increases are likely to occur in areas of moderate to high susceptibility that are already invaded. A small region in northern Nevada and eastern Oregon was projected to have decreased cover, whereas increased cover was projected within the Snake River Plain (southern Idaho). Some GRSG habitats and Priority Areas for Conservation are particularly vulnerable to fire and may require extra management attention because they are near areas currently dominated by cheatgrass with high annual variability in cover.

Topics: new geospatial data, nonnative invasive plants, weather and climate 


\section{Braun, C.E., and Schroeder, M.A., 2015, Age and sex identification from wings of sage- grouse: Wildlife Society Bulletin, v. 39, no. 1, p. 182-187.}

DOI: https://doi.org/10.1002/wsb.517

Background: Wing and feather characteristics are used to identify the sex and age of harvested GRSG and Gunnison sage-grouse. This paper is focused on refining methods of identifying the age and sex of birds from wings.

Objectives: The authors sought (1) to present a key to separate sex and age classes of GRSG based on wings and (2) to test the key with wings from birds of known age and sex.

Methods: Researchers obtained measurements of primary feathers from more than 1,000 birds originating in populations from three states between 1973 and 2012. Age classes-juvenile, yearling, and adult — were determined based on molt and size of primary feathers.

Location: Colorado, Oregon, Washington; MZ II, MZ V, MZ VI

Findings: Identification of sex is usually clear because of strong size and plumage dimorphism. Careful measurement of all 10 primary feathers is important, including accounting for missing feathers. The primary feather key was used to consistently classify birds into three age classes important for demographic research and monitoring.

Implications: The key developed here promotes accurate and consistent classification of harvested birds from wing samples. Distinction of the three age classes was deemed important because of differences in reproduction and survival among different ages. The key was deemed useful for Gunnison sage-grouse, in addition to GRSG, across the species' range.

Topics: other 


\section{Braun, C.E., and Williams, S.O., 2015, History of sage-grouse (Centrocercus spp.) in New Mexico: Southwestern Naturalist, v. 60, no. 2-3, p. 207-212.}

DOI: https://doi.org/10.1894/MCG-14.1

Background: Sage-grouse were extirpated from New Mexico by the early 20th century. Native populations are believed to have been Gunnison sage-grouse.

Objectives: The authors described (1) the history of sage-grouse in New Mexico based on fossil records and historical publications and (2) attempts to introduce GRSG that were unsuccessful.

Methods: The authors reviewed literature, including unpublished records, and analyzed previously collected specimens from museums.

\section{Location: New Mexico; MZ VII}

Findings: Fossil records document the presence of sage-grouse in several New Mexico counties. Gunnison sage-grouse, not GRSG, was the species native to New Mexico. The New Mexico Department of Game and Fish attempted to introduce 326 GRSG in several counties of northern New Mexico between 1933 and 1969, before the distinction between GRSG and Gunnison sagegrouse was recognized. All attempts failed.

Implications: Though Gunnison sage-grouse were once native to New Mexico, GRSG were not found there, and past introduction attempts were not successful.

Topics: translocation 


\section{Brooks, M.L., Matchett, J.R., Shinneman, D.J., and Coates, P.S., 2015, Fire patterns in the range of the greater sage-grouse, 1984-2013-Implications for conservation and management: U.S. Geological Survey Open-File Report 2015-1167, 66 p.}

DOI: https://doi.org/10.3133/ofr20151167

Background: Wildfire is one of the top threats to GRSG habitat across their range. A clear understanding of fire history and changes in fire dynamics over time is important for informing GRSG species and habitat conservation actions and fire management efforts.

Objectives: This report provided (1) an assessment of recent spatial and temporal patterns in fires over a 30-year period and (2) an assessment of the implications of fire history for management of GRSG habitats.

Methods: The authors compiled data representing fires from 1984 to 2013. They analyzed data for total burned area, fire recurrence (in the same area), fire size, fire rotation (the estimated time that would be needed to burn the entire area of interest), and fire season timing and length. Results were stratified by major vegetation type and by Greater sage-grouse Management Zone (MZ). A fire threats assessment incorporated information on soil moisture and temperature regimes.

Location: range-wide; MZ I, MZ II, MZ III, MZ IV, MZ V, MZ VI, MZ VII

Findings: During the 30-year period assessed, 11 percent of GRSG habitat burned, and some areas (2 percent) burned more than once. More than half of the area burned during the study period was big sagebrush, affecting 14 percent of the total area of existing big sagebrush systems in the study area. Fire area increased in all vegetation types over the study period. Fire occurrence, recurrence, and size varied among MZs. Most fires occurred in the western MZs, and fire sizes tended to be larger in the western region as well. Sixty percent of the fire area in the western MZs was in the Snake River Plain, Idaho (MZ IV). Estimated fire rotation for big sagebrush in the western region was 99 years. In the eastern GRSG range, total burned area was only 18 percent of GRSG habitat, with a majority occurring in grasslands.

Implications: The area of big sagebrush burned and prevalence of recurrent fire in big sagebrush are of concern because of the long time period it takes these systems to recover from fire and their susceptibility to invasion by nonnative annual grasses. The estimated fire rotation for big sagebrush in the western portion of the range is likely substantially shorter than it was historically. The fire threats assessment indicated a substantially lower threat from fire to GRSG habitat in the eastern region.

Topics: fire or fuel breaks, new geospatial data, non-native invasive plants 
*2019 Update* Burkhalter, C., Holloran, M.J., Fedy, B.C., Copeland, H.E., Crabtree, R.L., Michel, N.L., Jay, S.C., Rutledge, B.A., and Holloran, A.G., 2018, Landscape-scale habitat assessment for an imperiled avian species: Animal Conservation, v. 21, no. 3, p. 241-251.

DOI: https://doi.org/10.1111/acv.12382

Background: Understanding the suitability of habitat for wide-ranging species requires information on how landscape-scale habitat features influence the species' abundance at smaller spatial scales.

Objectives: The authors sought to determine how male GRSG abundance at leks varies based on sagebrush availability, landscape connectivity, and human infrastructure density around leks. They used this information to predict how GRSG populations might respond to spatial and temporal changes in landscape integrity.

Methods: Male GRSG abundance at leks was assessed from 2006-2016 in 31 "Wyoming Core Areas" established by the state and related to 15 GIS-derived variables representing landscape conditions surrounding these sites.

Location: Wyoming; MZ I, MZ II

Findings: Landscapes with greater connectivity, greater sagebrush abundance, and limited energy development were associated with greater GRSG abundance. The majority of habitat within core areas was predicted to support GRSG populations with stable or increasing growth rates. Core areas with small or declining populations tended to occur along distribution edges in eastern Wyoming.

Implications: Landscape-scale habitat associations described by the authors can be combined with local-scale assessments of habitat quality to provide a more comprehensive view of GRSG habitat quality in Wyoming.

Topics: broad-scale habitat characteristics, energy development, habitat selection, population estimates or targets 
Cade, B.S., 2015, Model averaging and muddled multimodel inferences: Ecology, v. 96, no. 9, p. 2370-2382.

DOI: https://doi.org/10.1890/14-1639.1.sm

Background: Model averaging using Akaike information criterion (AIC) weights has become a common approach to address uncertainty among multiple competing models. Species distribution and resource selection modeling efforts often employ model averaging in an attempt to determine the most important predictors of species occurrence. However, multicollinearity-a linear relation between predictors in a statistical model - affects scaling of the relation between predictors and the response variable in competing models.

Objectives: The author sought (1) to describe the statistical problems with using model-averaged coefficients, (2) to provide rules and a solution for accurate coefficient averaging in some situations, and (3) to demonstrate the erroneous conclusions created by ignoring this issue for a study predicting GRSG distribution in Colorado.

Methods: The author demonstrated how erroneous conclusions can result from using a relation based on flawed model averaging that uses information criteria to identify variables. The author then described a statistical solution based on standardizing coefficients by using the covariance structure. The author used erroneous conclusions based on model averaging of GRSG habitat selection models to demonstrate implications.

Location: Colorado; MZ II

Findings: Ecologists are often faced with large numbers of predictors, variability in effect sizes, and many combinations of predictors and often seek to reduce uncertainty in model results by combining multiple models. Averaging coefficients from multiple, competing models without standardizing them based on covariance of the predictors in each model may lead to misinterpretation of effect sizes and erroneous conclusions. Using information criteria such as AIC is useful for comparing models but not for assessing the importance of variables within models.

Implications: The problem described by the author is acute for species distribution and resource selection models because of a relation among predictors such as land-cover variables. Numerous studies on GRSG have used model averaging of regression coefficients, but it is difficult to determine the degree to which interpretations and conclusions are erroneous because of the improper use of this procedure. The detailed evaluation of the GRSG habitat model from Colorado indicated it was seriously flawed both because of improper use of model-averaged regression coefficients and because of other serious modeling issues.

Topics: broad-scale habitat characteristics, habitat selection 


\section{Cardinal, C.J., and Messmer, T.A., 2016, Ecology of greater sage-grouse populations inhabiting the northwestern Wyoming Basin: Human-Wildlife Interactions, v. 10, no. 2, p. 188-204.}

DOI: https://doi.org/10.26077/29zh-z063

Background: While GRSG in the Bear Lake Plateau and Valley population have been monitored via male lek counts since the 1960s, little is known about their seasonal movements and habitat use. An understanding of these factors is needed to inform management and conservation of this population.

Objectives: Research objectives were to examine (1) general ecology (such as home range sizes and survival rates), (2) seasonal movements, and (3) habitat use of the Bear Lake Plateau and Valley GRSG population.

Methods: The authors used telemetry of 153 GRSG to monitor GRSG locations from 2010 to 2012 to quantify survival, home range size, and nest and brood-rearing habitat selection. Aspect, slope, herbaceous cover, and vegetation visual obstruction were measured at nest sites, brood sites, and random points within 5 kilometers $(\mathrm{km})$ of nests and broods.

Location: Idaho, Utah, Wyoming; MZ II

Findings: The top model for survival included season (survival was highest in fall and lowest in summer) and capture area (east versus west). Annual survival rates did not differ for migratory and nonmigratory birds. Nest success varied by year, and nest sites had elevated visual obstruction and larger shrub sizes compared to random sites. Successful nests were located further from anthropogenic structures than unsuccessful nests. Home ranges were smaller for females than for males and for adults than for yearlings. The mean distance between seasonal ranges was $25 \mathrm{~km}$, with the greatest distances traveled to winter ranges. More than 25 percent of marked birds traveled fewer than $10 \mathrm{~km}$. Distance from nests to the nearest lek ranged from 0.2 to $11.4 \mathrm{~km}$.

Implications: Annual survival and home range sizes of this population were within ranges reported elsewhere. Nesting, brood, and overwinter survival rates were lower than reported elsewhere, and the distance between seasonal ranges was generally higher than reported elsewhere. Several individuals moved $100 \mathrm{~km}$ north and west, traversing from the Wyoming Basin to a range typically associated with the Snake River Plain; these migrating birds may serve as an important genetic link between Greater sage-grouse Management Zones II and IV. GRSG from this population used seasonal habitats in three states, indicating that managers from Utah, Idaho, and Wyoming must coordinate GRSG management efforts.

Topics: behavior or demographics, broad-scale habitat characteristics, effect distances or spatial scale, fences, habitat selection, infrastructure (roads, pipelines, powerlines, cell towers), sitescale habitat characteristics, survival 
Caudill, D., Guttery, M.R., Leone, E., Caudill, G., and Messmer, T.A., 2016, Age-dependence and individual heterogeneity in reproductive success of greater sage-grouse: Journal of Avian Biology, v. 47, no. 5, p. 719-723.

DOI: https://doi.org/10.1111/jav.00903

Background: Reproductive success is commonly reported to increase with age in birds until the onset of senescence. However, population-level effects of aging on reproduction may confound within-individual effects (such as aging) with between-individual effects (such as individual heterogeneity). A better understanding of the factors regulating populations can increase the effectiveness of conservations actions.

Objectives: Study objectives were to investigate the potential influence of (1) within-individual factors (such as individual maturity, experience, and foraging ability) compared to (2) betweenindividual factors (such as heterogeneity among individuals, nest site selection, and body condition) on reproductive success of GRSG.

Methods: The authors captured and tagged 248 female GRSG roosting near leks from 1998 to 2010 and used radio telemetry to track their locations. Age of individuals were determined, and 313 hens with nests were located so that nesting could be monitored. They also used telemetry to monitor 142 broods after hatching. The authors used three alternative models to evaluate the effect of hen age on nest initiation, nest success, and brood success.

Location: south-central Utah; MZ II

Findings: Models indicated an effect of age on nest initiation and nest success. Both within- and between-individual effects of age on nest initiation were positive, with between-individual effects being stronger than within-individual effects for nest initiation. Within-individual effects of age on nest success were also positive. The authors did not detect within- or betweenindividual effects of age on brood success.

Implications: Age appeared to affect nest initiation but not successful raising of broods. In the population, individuals with greater mean age initiated nests more often. Results were able to distinguish explanations related to within-individual versus between-individual processes, but they were not able to distinguish among specific competing hypotheses within each of those categories. The authors suggest conducting longitudinal studies that can distinguish between within- and between-individual effects of age whenever age is believed to affect reproductive success.

Topics: behavior or demographics 


\section{Caudill, D., Guttery, M.R., Terhune, T.M., Martin, J.A., Caudill, G., Dahlgren, D.K., and Messmer, T.A., 2017, Individual heterogeneity and effects of harvest on greater sage- grouse populations: Journal of Wildlife Management, v. 81, no. 5, p. 754-765.}

DOI: https://doi.org/10.1002/jwmg.21241

Background: The effects of harvest on wildlife populations vary depending on whether harvest mortality is compensatory or additive or falls somewhere along a continuum between these two end points. If harvest is selective and robust animals are more susceptible to harvest, it has the potential to negatively affect the fitness of the species over the long term.

Objectives: The researchers sought to investigate (1) potential additive and compensatory effects of harvest and harvest timing on grouse populations and (2) heterogeneity in survival and reproductive success of GRSG.

Methods: The authors corrected and revised previously published formulae used to estimate effects of harvest on survival to more accurately represent grouse populations. The authors also tested the role of individual heterogeneity in reproduction and survival using data from 184 GRSG collected during 1998-2010.

\section{Location: Utah; MZ III}

Findings: Using the revised formulae, the authors demonstrated that effects of selective harvest on grouse tend to be depensatory when robust individuals are more susceptible to harvest, and some level of compensation is likely when frail individuals are more susceptible to harvest. The authors found a positive correlation between survival and reproductive success in GRSG, supporting the hypothesis that nonbreeding GRSG are more likely to be of lower quality.

Implications: The authors suggest conservatively assuming that harvest effects are mostly additive whenever there is uncertainty but also acknowledging that mechanisms for compensatory mortality exist. Slight changes in the timing of GRSG harvest seasons may have important implications for the susceptibility of successful GRSG females to harvest during the fall transitional period when the distribution of adults and juveniles can change rapidly. Harvest regulations for GRSG should seek to reduce mortality of reproductively successful females and target nonbreeding birds.

Topics: hunting, survival, weather and climate 


\section{*2019 Update* Carlisle, J.D., Chalfoun, A.D., Smith, K.T., and Beck, J.L., 2018, Nontarget effects on songbirds from habitat manipulation for greater sage-grouse: implications for the umbrella species concept: Condor, v. 120, no. 2, p. 439-455.}

DOI: https://doi.org/10.1650/CONDOR-17-200.1

Background: According to the umbrella species concept, protecting or improving habitat for one species may indirectly benefit co-occurring species. However, localized management actions or habitat treatments intended to benefit the umbrella species could have negative effects on cooccurring species. GRSG is often assumed to serve as an umbrella species, capable of affording protections for other sagebrush-associated taxa.

Objectives: The goal of this study was to determine the effects of sagebrush mowing treatments, implemented to benefit GRSG, on three co-occurring songbird species.

Methods: The authors quantified abundance, nest-site selection, nestling condition, and nestling survival of three songbird species, before and after treatments in both mowed and control locations over three years.

Location: Wyoming; MZ II

Findings: Mowing treatments implemented to benefit GRSG resulted in negative effects to two sagebrush-obligate species, Brewer's Sparrows and Sage Thrashers, including complete loss of nesting habitat. Mowing positively affected the abundance and nesting success of Vesper Sparrows, a habitat generalist.

Implications: The authors suggest that sagebrush mowing treatments intended to benefit GRSG, an ostensive umbrella species at a broad spatial scale, could have negative effects on cooccurring species at more localized scales, especially if mowing treatments are widespread.

Topics: habitat restoration or reclamation, other topic, sagebrush removal, site-scale habitat characteristics 


\section{*2019 Update* Carlisle, J.D., Stewart, D.R., and Chalfoun, A.D., 2017, An invertebrate ecosystem engineer under the umbrella of sage-grouse conservation: Western North American Naturalist, v. 77, no. 4, p. 450-463.}

DOI: https://doi.org/10.3398/064.077.0406

Background: The GRSG is thought to function as an umbrella species, which can confer protections upon co-occurring species when GRSG habitat is protected or restored. Some of these co-occurring species have important ecological roles within the sagebrush steppe.

Harvester ants are ecosystem engineers, species which modify habitats in such a manner that they create or maintain habitats suitable for other species to utilize.

Objectives: The goal of this study was to determine the extent to which GRSG can serve as an umbrella species for ecologically important invertebrate species such as the harvester ant, an ecosystem engineer.

Methods: The authors assessed whether GRSG abundance, along with habitat characteristics, can predict the abundance of harvester ants at 72 sites in Wyoming.

Location: Wyoming, MZ II

Findings: After controlling for local habitat characteristics, locations with greater GRSG use also had greater densities of harvester ant mounds. However, a broader-scale index of GRSG breeding density was not related to ant mound density.

Implications: The authors suggest that the positive relationship between harvester ant mound density and GRSG density could be due to GRSG exploiting the ants for food resources, or due to indirect factors, such the two species simply sharing habitat preferences. They further suggest that GRSG non-breeding habitat and fine-scale GRSG abundance metrics are important for harvester ant conservation and for assessing the potential for GRSG to serve as an umbrella species in this region.

Topics: broad-scale habitat characteristics, effect distances or spatial scale, other topic, site-scale habitat characteristics 


\section{*2019 Update* Carlisle, J.D., Keinath, D.A., Albeke, S.E., and Chalfoun, A.D., 2018, Identifying holes in the greater sage-grouse conservation umbrella: Journal of Wildlife Management, v. 82, no. 5, p. 948-957.}

DOI: https://doi.org/10.1002/jwmg.21460

Background: Conservation theory suggests that protecting or improving habitat for an "umbrella species" may indirectly benefit co-occurring species. However, little is known about how the effectiveness of the umbrella species concept is influenced by reserve size and by habitat use similarity between the potential umbrella and beneficiary species.

Objectives: The authors' goals were to assess how the size of a reserve, created to benefit GRSG, might influence benefits to 52 co-occurring species and to evaluate the importance of habitat similarity between co-occurring species and GRSG in influencing umbrella species effectiveness.

Methods: To assess the importance of reserve size and location, the effectiveness of the implemented GRSG habitat reserve was compared, via GIS analyses, to other potential habitat reserves of various sizes and to simulated reserves of equal size that were placed without regard to GRSG habitat needs. The authors also determined whether co-occurring species' traits resulted in different levels of protection for these species within the designated GRSG reserve.

Location: Wyoming; MZ I, MZ II

Findings: The GRSG habitat reserve that was implemented protected 82 percent of Wyoming's GRSG population and 0-63 percent of the habitat of the 52 co-occurring species examined. In simulations, the implemented GRSG reserve provided better habitat protection than equally sized random areas for only 12 co-occurring species. Larger simulated reserves provided better protection for most co-occurring species examined, however some species received less protection than others, regardless of simulated reserve size. Co-occurring species with habitat requirements most similar to those of GRSG were most likely to benefit from the GRSG reserve umbrella, whereas species with small distributions or with relatively dissimilar habitat to that used by GRSG, received less habitat protection from the GRSG reserve.

Implications: The authors conclude that species with small distributions or those with habitat requirements that are only partly similar to those of GRSG will receive relatively fewer conservation benefits from GRSG as an umbrella species. These species may need separate protections established for their conservation. The authors further suggest that applying the umbrella species concept to GRSG and sagebrush habitats requires attention to details regarding the umbrella species, habitat reserves created to benefit the species, and the degree of habitat similarity shared with co-occurring species.

Topics: broad-scale habitat characteristics, effect distances or spatial scale, other topic, site-scale habitat characteristics 
*2019 Update* Carter, S.K., Manier, D.J., Arkle, R.S., Johnston, A., Phillips S.L., Hanser, S.E., and Bowen, Z.H., 2018, Annotated bibliography of scientific research on greater sagegrouse published since January 2015: U.S. Geological Survey Open File Report 2018-1008, p. 183.

DOI: https://doi.org/10.3133/ofr20181008

Background: The number and scope of new scientific publications related to GRSG can be difficult for resource managers to track as they evaluate whether updates are needed to existing planning and management documents.

Objectives: The authors' goal was to provide a single document and online database that tracks and summarizes all new publications related to GRSG.

Methods: To achieve this goal, a structured literature search was conducted within three online reference databases. Peer-reviewed journal articles and formal technical reports focusing on GRSG or factors related to GRSG management were summarized and included in a searchable online database. Articles and reports published between January 2015 and January 2018 were included.

Location: range-wide; MZ I, MZ II, MZ III, MZ IV, MZ V, MZ VI, MZ VII

Findings: One hundred-sixty-nine published products were summarized and included in the report and associated online database. Most often, products focused on GRSG behavior, demographics, and habitat selection. Few articles or reports addressed captive breeding, recreation, wild horses and burros, or range management structures.

Implications: The large body of peer-reviewed literature published on GRSG since 2015 and the summaries and searchable database describing this body of literature may help planning and management of diverse resources in rangelands of the western U.S.

Topics: agricultural conversion, behavior or demographics, broad-scale habitat characteristics, captive breeding, conifer expansion, effect distances or spatial scale, energy development, exurban development, fences, fire or fuel breaks, genetics, habitat restoration or reclamation, habitat selection, herbivory/grazing, human dimensions or economics, hunting, infrastructure (roads, pipelines, powerlines, cell towers), mining, new geospatial data, non-native invasive plants, other topic, population estimates or targets, predators or predator control, range mgmt. structures (water developments, mineral licks), recreation, sagebrush removal, site-scale habitat characteristics, survival, translocation, weather and climate, wild horses and burros 


\section{Caudill, D., Terhune, T.M., Bibles, B., and Messmer, T.A., 2016, Factors affecting seasonal movements of juvenile greater sage-grouse-A reconceptualized nest survival model: The Condor, v. 118, no. 1, p. 139-147.}

DOI: https://doi.org/10.1650/CONDOR-15-77.1

Background: Survival and movement of juvenile GRSG are important for understanding population demographics. Little is known about factors such as climate and habitat conditions that affect juvenile movement and survival, but these factors may be important for management and conservation.

Objectives: The authors sought to evaluate the effects of environmental factors, including snow depth, temperature, and precipitation, on fall movement patterns of juvenile GRSG.

Methods: Researchers used radio telemetry data from mid-August through mid-December and repurposed a nest survival model to analyze fall movement patterns of juvenile GRSG. They captured 91 GRSG juveniles and marked and tracked them for 2 years (2008-2009) after brood dispersal. Locations were acquired 1-4 times monthly. Analyses included date, climate (snow accumulation and depth and weekly temperature and precipitation variables), and elevation data along with juvenile age and sex as predictors.

Location: south-central Utah; MZ III

Findings: The strongest model indicated that, in the absence of precipitation, the potential for movement increased weekly. Weekly precipitation (likely snowfall that did not accumulate) increased the probability of movement earlier in the season, but the effect decreased over time. Movement was not affected by sex or age of the bird.

Implications: Results suggested that precipitation, rather than snow accumulation or depth, was the primary proximate driver of juvenile migration. Movement from late fall habitats to winter habitats was variable, indicating that the effects of harvest may vary with harvest timing and its relation to seasonal movements. Changes in climate may negatively affect GRSG if the onset of winter conditions is delayed, affecting the movement of juveniles to winter habitat. The model application presented here may be used to develop a better understanding of relations between environmental factors and GRSG behavior.

Topics: behavior or demographics, weather and climate 
Chambers, J.C., Beck, J.L., Bradford, J.B., Bybee, J., Campbell, S., Carlson, J., Christiansen, T.J., Clause, K.J., Collins, G., Crist, M.R., Dinkins, J.B., Doherty, K.E., Edwards, F., Espinosa, S., Griffin, K.A., Griffin, P., Haas, J.R., Hanser, S.E., Havlina, D.W., Henke, K.F., Hennig, J.D., Joyce, L.A., Kilkenny, F.F., Kulpa, S.M., Kurth, L.L., Maestas, J.D., Manning, M., Mayer, K.E., Mealor, B.A., McCarthy, C., Pellant, M., Perea, M.A., Prentice, K.L., Pyke, D.A., Wiechman, L.A., and Wuenschel, A., 2017, Science framework for conservation and restoration of the sagebrush biome-Linking the Department of the Interior's Integrated Rangeland Fire Management Strategy to long-term strategic conservation actions. Part 1, Science basis and applications: U.S. Department of Agriculture, Forest Service, Rocky Mountain Research Station, General Technical Report RMRS-GTR-360, 213 p.

https://www.fs.fed.us/rmrs/publications/science-framework-conservation-and-restorationsagebrush-biome-linking-department.

Background: This report builds on the approach developed to address persistent and anthropogenic threats to sagebrush ecosystems and to provide a scientific basis for management decisions in the western and eastern parts of the GRSG range. Part 2 of this report is scheduled to be published in 2018 and describes the application of this information to monitoring, climate adaptation, management of wildfire and vegetation, invasive plant species, seeding strategies, livestock grazing, and wild horses and burros.

Objectives: This framework compiled and expanded the necessary scientific information to enable managers to (1) identify priority areas for conservation and restoration actions, (2) effectively allocate budgets, and (3) implement strategic actions for the entire sagebrush biome.

Methods: This report described (1) how environmental characteristics and persistent ecosystem and anthropogenic threats differ across the sagebrush biome, (2) how the concepts of resilience to disturbance and resistance to invasive plants and the habitat and population information of GRSG and other wildlife species can be applied to management, and (3) how ecosystem threats to sagebrush ecosystems and sagebrush-dependent species can be addressed by using information on resilience and resistance, species habitat requirements and populations, and the dominant threats.

Location: range-wide; MZ I, MZ II, MZ III, MZ IV, MZ V, MZ VI, MZ VII

Findings: Geospatial data and analyses can be used to illustrate how resistance and resilience, species habitats, and species populations vary across assessment areas. This information, coupled with overlays of the dominant threats, can be used to target areas for management. A habitat matrix that couples information on resistance and resilience with species habitat requirements can be used to identify appropriate management strategies for specific areas. The habitat matrix coupled with ecological site descriptions and state and transition models based on resistance and resilience can be used to step down the information to project scales. Detailed examples are provided to illustrate the use of the information and concepts.

Implications: Coupling spatial information on resistance, resilience, and species habitat requirements provides the basis for evaluating the effects of restoration and conservation actions 
at much larger scales than in the past. This strategic, multiscale approach provides a direct connection between new science and agency prioritization and funding processes. It also allows a shared vision of supporting partnerships and collaborations with the data and science needed to make strategic conservation investments.

Topics: agricultural conversion, broad-scale habitat characteristics, conifer expansion, energy development, ex-urban development, fire or fuel breaks, habitat restoration or reclamation, herbivory/grazing, infrastructure (roads, pipelines, powerlines, cell towers), mining, new geospatial data, non-native invasive plants, population estimates or targets, recreation, sagebrush removal, weather and climate, wild horses and burros 
*2019 Update* Chambers, J.C., Beck, J.L., Bradford, J.B., Bybee, J., Campbell, S., Carlson, J., Christiansen, T.J., Clause, K.J., Collins, G., Crist, M.R., Dinkins, J.B., Doherty, K.E., Edwards, F., Espinosa, S., Griffin, K.A., Griffin, P., Haas, J.R., Hanser, S.E., Havlina, D.W., Henke, K.F., Hennig, J.D., Joyce, L.A., Kilkenny, F.M., Kulpa, S.M., Kurth, L.L., Maestas, J.D., Manning, M., Mayer, K.E., Mealor, B.A., McCarthy, C., Pellant, M., Perea, M.A., Prentice, K.L., Pyke, D.A., Wiechman, L.A., and Wuenschel, A., 2017, Science framework for conservation and restoration of the sagebrush biome: Linking the Department of the Interior's Integrated Rangeland Fire Management Strategy to long-term strategic conservation actions. Part 1. Science basis and applications: Gen. Tech. Rep. RMRS-GTR360. Fort Collins, CO: U.S Department of Agriculture, Forest Service, Rocky Mountain Research Station. p. 213.

DOI: https://doi.org/10.2737/RMRS-GTR-389

Background: The Department of the Interior's Integrated Rangeland Fire Management Strategy provides a comprehensive framework for guiding decisions related to the management of wildland fires in rangelands of the western U.S. Many of these rangelands provide habitat for GRSG and many management decisions related to wildfire are affected by, and affect, GRSG.

Objectives: The Science Framework intends to link the Department of the Interior's Integrated Rangeland Fire Management Strategy with conservation actions within the sagebrush ecosystem in a long-term, strategic manner.

Methods: The authors combine resistance and resilience concepts with information on specieshabitat relationships and species' distributions to create a geospatial process that can be used at intermediate spatial scales to prioritize areas for management actions.

Location: range-wide; MZ I, MZ II, MZ III, MZ IV, MZ V, MZ VI, MZ VII

Findings: The authors provide tools such as a resilience and resistance habitat matrix, tools for determining appropriate management actions, and geospatial data, maps, and models.

Implications: The Science Framework will inform conservation strategies for sagebrush ecosystems, sagebrush-dependent species, and human use of these resources. It will also help managers prioritize restoration and mitigation actions.

Topics: broad-scale habitat characteristics, conifer expansion, habitat restoration or reclamation, herbivory/grazing, human dimensions or economics, new geospatial data, non-native invasive plants, site-scale habitat characteristics 
Chambers, J.C., Beck, J.L., Campbell, S., Carlson, J., Christiansen, T.J., Clause, K.J., Dinkins, J.B., Doherty, K.E., Griffin, K.A., Havlina, D.W., Mayer, K.F., Hennig, J.D., Kurth, L.L., Maestas, J.D., Manning, M., Mealor, B.A., McCarthy, C., Perea, M.A., and Pyke, D.A., 2016, Using resilience and resistance concepts to manage threats to sagebrush ecosystems, Gunnison sage-grouse, and greater sage-grouse in their eastern range-A strategic multi-scale approach: U.S. Department of Agriculture, Forest Service, Rocky Mountain Research Station, General Technical Report RMRS-GTR-356, 143 p.

DOI: https://www.fs.usda.gov/rmrs/publications/using-resilience-and-resistance-conceptsmanage-threats-sagebrush-ecosystems-gunnison

Background: In the western range of GRSG, habitat quality was driven by landscape cover of sagebrush. Previous work by this group (which was organized by the Western Association of Fish and Wildlife Agencies) produced a GRSG habitat matrix that related resistance and resilience to landscape cover of sagebrush. That matrix, however, does not work as well in the GRSG eastern range or for Gunnison sage-grouse.

Objectives: The authors (1) provide scientific information to guide prioritization of resources to address ecosystem threats, (2) provide a consistent framework for communication, and (3) identify strategies that conserve GRSG in the eastern range and Gunnison sage-grouse and promote ecosystem conservation.

Methods: This report (1) summarized environmental characteristics and persistent ecosystem and anthropogenic threats in eastern sagebrush ecosystems, (2) described how the concepts of resilience to disturbance and resistance to invasive plants can be applied to management in the eastern range, (3) updated information on GRSG habitats, and (4) developed an approach for addressing ecosystem threats to sagebrush ecosystems based on resilience and resistance, GRSG breeding habitat probabilities, and the dominant threats.

Location: Colorado, eastern Idaho, Montana, North Dakota, South Dakota, eastern Utah, Wyoming; MZ I, MZ II, MZ VII

Findings: Soil temperature and moisture regimes can be used to map how resistance and resilience differ across the landscape. GRSG and Gunnison sage-grouse habitats can be mapped using breeding habitat probabilities and can be further refined by using a population index based on breeding bird densities. Areas can be targeted for management based on geospatial analyses and maps of soil temperature and moisture regimes, breeding habitat probabilities, the population index, and the dominant threats, including oil and gas development and agricultural conversion.

Implications: This holistic and strategic approach to management may be used to address threats and support habitat conservation and restoration because an understanding of ecosystem potential clarifies potential risks and opportunities. A sage-grouse habitat matrix based on relative resistance and resilience and GRSG habitat requirements can be used to identify ecosystem responses to both disturbance and management actions and to determine appropriate management strategies. The sage-grouse habitat matrix, coupled with ecological type 
descriptions and state and transition models based on resistance and resilience, can be used to step down to the project scale.

Topics: agricultural conversion, broad-scale habitat characteristics, conifer expansion, energy development, ex-urban development, fire or fuel breaks, habitat restoration or reclamation, herbivory/grazing, new geospatial data, non-native invasive plants, population estimates or targets, recreation, sagebrush removal, weather and climate, wild horses and burros 


\section{Chambers, J.C., Maestas, J.D., Pyke, D.A., Boyd, C.S., Pellant, M., and Wuenschel, A., 2017, Using resilience and resistance concepts to manage persistent threats to sagebrush ecosystems and greater sage-grouse: Rangeland Ecology and Management, v. 70, no. 2, p. $149-164$.}

DOI: https://doi.org/10.1016/j.rama.2016.08.005

Background: Conservation strategies need to address persistent and pervasive ecological forces like invasive species and disturbance regimes that strongly affect species of concern, in addition to anthropogenic activities. Ecological concepts of resilience and resistance can help prioritize management of GRSG habitat and may be applicable to other ecosystems.

Objectives: This article provided the scientific basis for prioritizing areas for management and determining appropriate management strategies for the conservation and restoration of sagebrush ecosystems.

Methods: This report (1) summarized the threats of wildfire, invasive annual grasses, and conifers in western sagebrush ecosystems; (2) provided an overview of resilience to disturbance and resistance to invasive annual grasses and illustrated how these concepts may be applied to management of sagebrush ecosystems; (3) provided information on GRSG habitats; and (4) developed an approach for addressing ecosystem threats to sagebrush ecosystems based on resistance and resilience, GRSG habitat requirements, and the dominant threats.

Location: California, Idaho, western Montana, Nevada, Oregon, Utah, Washington; MZ III, MZ IV, MZ V, MZ VI

Findings: Soil temperature and moisture regimes are strongly related to resistance and resilience and can be used to map how resistance and resilience differ across the landscape. GRSG habitats are strongly related to landscape cover of sagebrush and can be further refined using breeding bird densities. Areas can be targeted for management based on geospatial analyses and maps of soil temperature and moisture regimes, landscape cover of sagebrush, breeding bird densities, and the dominant threats, including wildfire, invasive annual grasses, and conifer expansion.

Implications: This strategic, multiscale approach provides the scientific basis for prioritizing areas for management where benefits are likely to be greatest and for determining management strategies that are likely to be most effective. The sage-grouse habitat matrix based on relative resistance and resilience and GRSG habitat requirements can be used to identify risk of plant invasions, responses to disturbances (such as wildfire), and likely effectiveness of management actions. Management approaches may be adjusted to reflect the ability of the ecosystem to respond, given disturbance, in areas that support large numbers of GRSG.

Topics: broad-scale habitat characteristics, conifer expansion, fire or fuel breaks, habitat restoration or reclamation, non-native invasive plants, weather and climate 


\section{Christiansen, T.J., and Belton, L.R., 2017, Wyoming sage-grouse working groups-Lessons learned: Human-Wildlife Interactions, v. 11, no. 3, p. 274-286.}

DOI: https://doi.org/10.26077/1bg9-2r18

Background: Community-based, voluntary conservation efforts were part of the U.S. Fish and Wildlife Service decision to not list GRSG under the Endangered Species Act of 1973. Local working groups are one mechanism for achieving the communication, collaboration, trust, learning, and responsibility needed for voluntary conservation efforts to succeed.

Objectives: The goal of the article was to document the process used by Wyoming GRSG local working groups and Wyoming's Sage-Grouse Implementation Team to help develop policies and implement actions to achieve GRSG conservation in balance with a local economy that is largely based on resource extraction.

Methods: The authors describe the process of standing up the local working groups, their charter, member selection and responsibilities, and lessons learned. Similar information is described for the Sage-Grouse Implementation Team.

Location: Wyoming; MZ I, MZ II

Findings: The local working groups were formed in 2004 and consisted of a facilitator and representatives from diverse sectors including agriculture, industry, hunting, conservation, and agencies. Groups completed GRSG conservation plans in 2007 and updated them in 2014. The State allocated significant funds for project implementation through 2017, and local working groups were involved in implementing more than 200 diverse projects. The Sage-Grouse Implementation Team developed Wyoming's Core Area Policy, implemented in 2008.

Implications: The strong initial organizational and financial support provided to Wyoming's local working groups may explain participants' positive perceptions of many aspects of the groups. Multiple studies have found different aspects of the Core Area Policy to be effective. Challenges remain, including recent Federal and State decisions that override recommendations of the local working groups.

Topics: energy development, human dimensions or economics 


\section{Clawson, M.V., Skalski, J.R., Lady, J.M., Hagen, C.A., Millspaugh, J.J., Budeau, D., and Severson, J.P., 2017, Performing statistical population reconstruction using program PopRecon 2.0: Wildlife Society Bulletin, v. 41, no. 3, p. 581-589.}

DOI: https://doi.org/10.1002/wsb.790

Background: Estimation of population demographics can be challenging with limited data. This application of PopRecon software enables estimation of important demographic information by using the harvest data that management agencies have collected consistently for many years.

Objectives: The authors sought to introduce a novel application of the software program PopRecon 2.0; they used GRSG harvest data to parameterize the model and reconstruct population demographic parameters.

Methods: Various methods have been employed to conduct statistical population reconstructions in the past. Here, the authors used the Horvitz-Thompson method and input age-at-harvest and harvest effort data to produce annual estimates of abundance, harvest probabilities, and natural survival using the PopRecon modeling software. Additional needed parameters (such as age- or year-specific survival) can be input by the user or derived from the input data. Harvest data collected from 1993 to 2015 informed the model.

\section{Location: Oregon; MZ V, MZ VI}

Findings: Modeled harvest data provided estimates sufficient to determine annual abundance of the male GRSG ranging from a high of 9,955 in 2004 to a low of 5,278 in 2014. Estimates of male abundance increased initially and then declined over time, apparently the result of low recruitment. Harvest probability was low, leading to higher error around abundance estimates, and declined further in recent years. Population estimates for the eastern Oregon populations were variable, demonstrating cyclical population dynamics and high variability in recruitment, and comparable to estimates from other research.

Implications: Population reconstruction using statistical models is useful when limited data are available. The software described here supports population reconstruction by using commonly collected harvest data, and the rigor of estimates improves with better empirical estimates of abundance and demographic change.

Topics: hunting, population estimates or targets 


\section{Coates, P.S., Andrle, K.M., Ziegler, P.T., and Casazza, M.L., 2016, Monitoring and research on the Bi-State distinct population segment of greater sage-grouse (Centrocercus urophasianus) in the Pine Nut Mountains, California and Nevada-Study progress report, 2011-15: U.S. Geological Survey Open-File Report 2015-1222, 40 p.}

DOI: https://doi.org/10.3133/ofr20151222

Background: The Bi-State population of GRSG is a unique population compared to GRSG elsewhere in the species' range. Threats to this population are similar to range-wide threats, but they may be exacerbated by isolation.

Objectives: This research, through a collaborative effort of land and wildlife administrators and researchers, was designed to (1) identify patterns of habitat selection, (2) estimate vital rates of the population, (3) monitor breeding behavior, (4) monitor seasonal and annual movements, (5) assess potential effects of conifer encroachment, (6) assess effects of avian predators, and (7) develop a habitat map.

Methods: The research team used telemetry to track 120 GRSG and locate habitats used by GRSG from 2011 to 2015; they then used field measurements to describe the vegetation characteristics of those sites. Predator surveys were conducted in proximity to nests and in random locations to assess potential effects of ravens and raptors on GRSG nest success and survival.

\section{Location: California, Nevada; MZ V}

Findings: During spring and summer, GRSG were located at varying distances from leks: an average of 3.4 kilometers $(\mathrm{km})$ in April, $17.1 \mathrm{~km}$ in May, and $38.7 \mathrm{~km}$ in June. Two birds were observed to travel great distances - more than $100 \mathrm{~km}$ from the lek. Habitat selection, including for nesting, was characterized by greater sagebrush cover and height and greater abundance of herbaceous species compared to the surrounding area. Adult survival was high, but not as high as observed in other populations. Predation was a predominant cause of observed adult mortality. Less than half of observed nests were successful. Several nest failures were attributed to lack of fertilization, but depredation was also observed.

Implications: Behavior of GRSG in the Bi-State population is similar to elsewhere in the range, and telemetry provided important insights into home range, habitat selection, and seasonal movements. Because it is isolated from other populations, continued monitoring of this population will be important. GRSG in the Bi-State population avoided areas with conifer cover, presumably avoiding predation risk associated with avian predators.

Topics: behavior or demographics, conifer expansion, habitat selection, predators or predator control, site-scale habitat characteristics, survival 
Coates, P.S., Brussee, B.E., Howe, K.B., Gustafson, K.B., Casazza, M.L., and Delehanty, D.J., 2016, Landscape characteristics and livestock presence influence common ravensRelevance to greater sage-grouse conservation: Ecosphere, v. 7, no. 2, article e01203, 20

p.

DOI: https://doi.org/10.1002/ecs2.1203

Background: Over the last four decades, raven abundance has increased within the range of GRSG. Other studies indicate that GRSG nest success decreases with increased raven abundance. High numbers of ravens have been associated with anthropogenic features and activities that support ravens.

Objectives: This project sought to investigate factors that may influence raven occurrence, including (1) livestock, (2) landscape characteristics, and (3) proximity to GRSG leks.

Methods: The authors conducted raven point-count surveys in spring and summer from 2010 to 2012 across a semiarid sagebrush environment that has been altered and fragmented by human activities. Surveyors also noted the presence of li vestock and anthropogenic features at each point.

Location: Idaho; MZ IV

Findings: Raven occurrence was positively associated with the presence of livestock, low topographic complexity, low elevations, and proximity to croplands and to the nearest GRSG lek. Raven occurrence was also positively associated with the proportion of upland wet meadows (within a 4,000-hectare analysis window) and areas with urbanization and negatively associated with forested areas. Limited support was found for raven occurrence correlating with shrublands, proximity to open water, and anthropogenic subsidies.

Implications: Ravens are known to depredate GRSG nests, and results demonstrated a positive association between raven occurrence and leks. The strongest association was between raven occurrence and the presence of cattle, apparently because of the food and water subsidies associated with cattle. Importantly, cattle showed stronger support for raven occurrence than anthropogenic resource subsidies. The authors suggest that reducing anthropogenic subsidies is likely to be most effective in reducing raven densities over the long term and that limiting livestock grazing near leks during nesting and brood rearing may reduce GRSG exposure to ravens and increase GRSG reproduction.

Topics: agricultural conversion, herbivory/grazing, infrastructure (roads, pipelines, powerlines, cell towers), predators or predator control, range mgmt. structures (water developments, mineral licks) 
Coates, P.S., Brussee, B.E., Ricca, M.A., Dudko, J.E., Prochazka, B.G., Espinosa, S.P., Casazza, M.L., and Delehanty, D.J., 2017, Greater sage-grouse (Centrocercus urophasianus) nesting and brood-rearing microhabitat in Nevada and California-Spatial variation in selection and survival patterns: U.S. Geological Survey Open-File Report 2017-1087, 79 p.

DOI: https://doi.org/10.3133/ofr20171087

Background: Considerable variability in GRSG habitat conditions in different seasons leads to confusion about the types of habitat required to sustain populations. This study focused on nesting and brood-rearing microhabitat (spring and summer seasons) to help elucidate conditions selected by GRSG during these seasons within the Great Basin.

Objectives: This research sought to identify specific microhabitat vegetation components that influence nest and brood site selection and survival of GRSG to better elucidate habitat requirements across two hydrographic zones (wet and dry) within the Great Basin.

Methods: Telemetry was used to track individual GRSG throughout the nesting and broodrearing season; 703 nest site locations were identified. Multiple field measurements of vegetation were made at used and random points to estimate habitat selection in 16 study areas from 2009 to 2016. Additionally, habitat characteristics were associated with successful and unsuccessful nests and with reproductive success (nests and chicks).

Location: California, Nevada; MZ III, MZ IV

Findings: Overall, horizontal and vertical cover (that is, cover composed of multiple vegetation characteristics) were the most important factors influencing site selection and reproductive success. Sagebrush cover contributed the most to the nesting life stage, but in burned areas, GRSG selected bunchgrasses and other shrubs. Concealing cover was less important during brood rearing, but day-night use patterns indicated heterogeneous composition was important because of the combination of forage and protective cover. Grass height showed variable effects across the Great Basin. For example, grass height was critical to survival in drier regions that consisted of relatively shorter perennial grasses.

Implications: Management actions that focus on providing overall vegetation cover, especially during nesting, will likely be effective at improving nesting and brood-rearing habitat. Although shrubs played a key role in habitat selection and survival, height and cover of grasses were also important and varied across the landscape. Based on these findings, the authors provided values for suitable, marginal, and unsuitable habitat conditions for each vegetation characteristic as an example that could help guide effective habitat management decisions.

Topics: behavior or demographics, fire or fuel breaks, habitat selection, site-scale habitat characteristics, weather and climate 


\section{Coates, P.S., Casazza, M.L., Brussee, B.E., Ricca, M.A., Gustafson, K.B., Sanchez-Chopitea, E., Mauch, K., Niell, L., Gardner, S., Espinosa, S., and Delehanty, D.J., 2016, Spatially explicit modeling of annual and seasonal habitat for greater sage-grouse (Centrocercus urophasianus) in Nevada and northeastern California-An updated decision-support tool for management: U.S. Geological Survey Open-File Report 2016-1080, 160 p.}

DOI: https://doi.org/10.3133/ofr20161080

Background: This report supports adaptive management efforts by updating a previously developed decision support tool for GRSG populations in California and Nevada. The revision takes advantage of additional data to revise seasonal habitat models.

Objectives: This project (1) compiled telemetry data from multiple populations and multiple seasons; (2) utilized improved vegetation maps to represent habitat conditions; (3) refined habitat suitability models to develop a habitat suitability index for three seasons - spring, summer, and winter; and (4) combined spatially explicit space use models, derived from lek count data, with habitat surfaces to help inform conservation planning.

Methods: The authors built on previous work to model GRSG habitat in Nevada and California at broad spatial scales. They used 813 individually marked sage-grouse $(>14,000$ telemetry locations) from 10 study sites and modeled habitat selection by GRSG across three seasons while considering functional differences between two hydrographic zones (wet and dry). Subregions with different habitat characteristics were evaluated separately and then combined to develop a composite habitat map for the region. The authors also combined GRSG habitat selection models with space use maps and abundance maps based on lek count data to create a map depicting management categories for conservation planning decisions.

\section{Location: California, Nevada; MZ V}

Findings: This project resulted in multiple spatial products related to GRSG habitat, space use, and abundance. First, the authors provided broad-scale seasonal habitat maps based on modelaveraged resource selection functions. Generally, intact sagebrush was selected and conifers were avoided across the study areas. However, the authors found sometimes substantial variation in functional response of GRSG to multiple vegetation and land-cover features between seasons and across spatial scales. The authors also provided a composite annual habitat map depicting areas that met multiple seasonal requirements. Lastly, combining the habitat maps with space use models allowed a depiction of potential prioritization scenarios that could be used to guide management decisions.

Implications: This revised report incorporated new information from multiple sources, including updated GRSG telemetry locations, high-resolution vegetation maps, and seasonal habitat suitability indices. GRSG habitat area increased by 6.5 percent compared to findings in the earlier report, with increases of a similar magnitude in core, priority, and general GRSG habitat management categories.

Topics: agricultural conversion, broad-scale habitat characteristics, conifer expansion, effect distances or spatial scale, habitat selection, new geospatial data, site-scale habitat characteristics 
Coates, P.S., Casazza, M.L., Ricca, M.A., Brussee, B.E., Blomberg, E.J., Gustafson, K.B., Overton, C.T., Davis, D.M., Niell, L.E., Espinosa, S.P., Gardner, S.C., and Delehanty, D.J., 2016, Integrating spatially explicit indices of abundance and habitat quality-An applied example for greater sage-grouse management: Journal of Applied Ecology, v. 53, no. 1, p. 83-95.

DOI: https://doi.org/10.1111/1365-2664.12558

Background: Models of species distributions are a foundational tool in conservation planning. However, for lekking species, occurrences or abundances based on lek counts do not provide information on fine-scale patterns of GRSG use of the broader breeding habitat area that may be needed to inform conservation efforts. Habitat selection indices based on individual GRSG patterns of habitat use can be incorporated into a joint model with both broad- and fine-scale inputs, which may inform both broad- and local-scale conservation actions.

Objectives: Study objectives were to describe a process for combining broad-scale information on GRSG distribution based on lek locations and counts with fine-scale information on habitat use based on telemetry locations of individual GRSG.

Methods: Using a combination of telemetry data (35,883 locations from 1,612 GRSG collected from 1998 to 2013) and existing spatial information, this project measured and modeled associations of GRSG with habitat and environmental patterns at three spatial scales (radii of $167.9,439.5$, and 1451.7 meters) across 12 subregions of the Great Basin. The spatial distribution of leks and the number of male GRSG associated with each lek were used to define the broad-scale density distribution of GRSG across the region. Resource selection functions were used to delineate habitats at a finer scale based on probability of GRSG occurrence while accounting for differences in sampling across seasons. The authors used the intersection of the broad- and fine-scale information to develop four management scenario categories-core areas, priority areas for management action, general areas, and nonhabitat.

Location: California, Nevada; MZ III, MZ IV, MZ V

Findings: GRSG selected for sagebrush habitats at the largest spatial scale, avoided conifers at the intermediate scale, and selected for proximity to water. The highest habitat selection indices and greatest relative abundance of GRSG were both in northern Nevada. All known active leks were surrounded by some amount of core area.

Implications: The use of a combination of broad- and fine-scale data sources provides a tool that may inform conservation and management actions at local to regional scales. The results correspond well with other published literature describing GRSG ecology, and validation tests indicated strong agreement. The authors note limitations of their assessment, including that microhabitat features important for specific life stages may be missed, population source-sink dynamics are not incorporated, and seasonal habitats are not individually considered. The management scenario categories used here are examples; categories should be developed together with stakeholders in light of specific goals and applications. 
Topics: broad-scale habitat characteristics, effect distances or spatial scale, habitat selection, new geospatial data, site-scale habitat characteristics 
Coates, P.S., Prochazka, B.G., Ricca, M.A., Gustafson, K.B., Ziegler, P., and Casazza, M.L., 2017, Pinyon and juniper encroachment into sagebrush ecosystems impacts distribution and survival of greater sage-grouse: Rangeland Ecology and Management, v. 70, no. 1, p. 25-38.

DOI: https://doi.org/10.1016/j.rama.2016.09.001

Background: Pinyon and juniper woodlands have expanded significantly into sagebrush ecosystems in the Great Basin. GRSG avoid even low densities of pinyon-juniper, and pinyonjuniper encroachment is considered a major threat to GRSG. Understanding the effects of encroachment on GRSG behavior and demographics could help inform management actions.

Objectives: The authors used a Bayesian modeling approach to concurrently assess (1) avoidance of pinyon-juniper cover and (2) changes in annual survival probabilities of GRSG relative to time-dependent use of pinyon-juniper cover to inform conifer removal treatments to benefit the Bi-State population of GRSG.

Methods: Focusing on the Bi-State GRSG population, the authors modeled relations between GRSG behavior and survival based on telemetry data from 162 GRSG over 6 years (2003-2005 and 2011-2013) and multiple predictor variables: high-resolution maps of conifer cover, sagebrush cover, and predicted productivity of habitats based on a soil-moisture and temperature gradient. Conifer and sagebrush cover were quantified at three biologically relevant spatial scales (radii of 167.9, 439.5, and 1451.7 meters). Predictor variables were quantified at both used and associated random locations. Phases I (shrub dominant), II (shrub and pinyon-juniper codominant), and III (pinyon-juniper dominant) of conifer encroachment were examined.

Location: California, Nevada; MZ III

Findings: GRSG avoided pinyon-juniper cover in all phases of expansion (Phases I, II, and III). GRSG appeared to tolerate areas with up to 30-40 percent of the landscape covered with Phase I conifer expansion (approximately 2 percent actual tree canopy cover), but they strongly avoided all conifer cover in Phases II and III. GRSG that avoided conifer cover were more likely to survive; a 10 percent increase in avoidance of Phase I conifer expansion was associated with a 1.9 percent increase in annual survival. There was not strong support for increased annual survival associated with avoidance of conifer cover in Phases II and III. In more productive areas, increases in Phase I conifer expansion were associated with decreased annual GRSG survival.

Implications: Avoidance of Phase I conifer cover was the most variable among individuals, and use of Phase I conifer cover areas posed a clear risk to survival. Expansion of conifers in the most productive habitats may create an ecological trap, whereby GRSG select habitats for use based on forage availability but ignore risk. Prioritizing removal of all conifers in Phase I areas, particularly areas of high productivity, may provide the greatest benefit to GRSG vital rates.

Topics: behavior or demographics, conifer expansion, effect distances or spatial scale, habitat selection, site-scale habitat characteristics, survival 
*2019 Update* Coates, P.S., Prochazka, B.G., Ricca, M.A., Halstead, B.J., Casazza, M.L., Blomberg, E.J., Brussee, B.E., Wiechman, L., Tebbenkamp, J., Gardner, S.C., and Reese, K.P., 2018, The relative importance of intrinsic and extrinsic drivers to population growth vary among local populations of greater sage-grouse: an integrated population modeling approach: AUK, v. 135, no. 2, p. 240-261.

DOI: https://doi.org/10.1642/AUK-17-137.1

Background: Quantifying population growth rates and determining their drivers can be difficult because population data are often derived from multiple, spatially nested scales such as leks, subpopulations, and metapopulations. This makes it challenging to separate intrinsic from extrinsic factors and to implement independent vital rate estimates for spatially nested populations.

Objectives: The goal of this study was to use integrated population models to investigate drivers of GRSG population growth within the Bi-State Distinct Population Segment (DPS) of GRSG.

Methods: The authors used 13 years of lek count and telemetry data collected within six BiState DPS sub-populations.

Location: California, Nevada; MZ III

Findings: Across the Bi-State DPS, models indicated that relative population abundance, in its entirety, did not exhibit evidence of a decrease or increase in trend over the course of 13 years. Instead, annual growth rates were influenced by inter-annual changes in precipitation, with a lag time of one-year. Across sub-populations, however, growth and demographic rates varied and were influenced by different factors from one another.

Implications: Use of integrated population models allowed the authors to disentangle the effects of precipitation variability on GRSG populations at the DPS level from those at the subpopulation level. This information will help resource managers understand how growth rates in the Bi-State DPS can appear stable, while at the same time, certain sub-populations may decline due to extrinsic factors, such as drought, unless management actions are taken.

Topics: behavior or demographics, population estimates or targets, site-scale habitat characteristics, survival, weather and climate 
Coates, P.S., Prochazka, B.G., Ricca, M.A., Wann, G.T., Aldridge, C.L., Hanser, S.E., Doherty, K.E., O'Donnell, M.S., Edmunds, D.R., and Espinosa, S.P., 2017, Hierarchical population monitoring of greater sage-grouse (Centrocercus urophasianus) in Nevada and California-Identifying populations for management at the appropriate spatial scale: U.S. Geological Survey Open-File Report 2017-1089, 49 p.

DOI: https://doi.org/10.3133/ofr20171089

Background: Both local factors (such as wildfire and oil and gas development) and regional factors (such as drought) can drive GRSG population dynamics. Accordingly, monitoring methods need to recognize potential drivers at both local and regional scales. To help recognize important trends and adapt habitat management across scales, a framework for multiscale population monitoring was developed.

Objectives: The authors sought to define methods for monitoring local and regional trends in GRSG populations that would (1) be sensitive to population declines but robust to demographic variability and (2) distinguish between local and regional population effects and trends.

Methods: This report described a framework and analyses for assessing GRSG population trends at the level of an individual lek, a cluster of leks composing a local population, and a region that includes multiple populations. This hierarchical structuring of trend analysis was used to distinguish trends, and potential causes, at different spatial scales. Lek count data from 2003 to 2016 were used to estimate population trends, and telemetry data from 274 tagged GRSG (20122016) were used to model movement patterns.

Location: California, Nevada; MZ III, MZ IV, MZ V

Findings: The authors developed methods for defining populations using clustering of leks based on proximity and potential for shared habitats and genetic exchange. Clusters were defined at multiple scales to help inform monitoring: an individual lek, neighborhood clusters of leks (for which population changes are more likely driven by local factors that may be under management control), and climate clusters (for which population changes are more likely related to regional factors over which managers likely have little control). The authors described population dynamics and ecological and management effects at each scale. They used simulations to identify decoupling of trends across spatial scales that provides early warning of when and where populations may be declining.

Implications: Monitoring and evaluation of trends at multiple nested scales enabled recognition of important local population trends and effects of local disturbances as well as population trends that may reflect destabilization of the population and regional declines that may be difficult to manage. GRSG populations are highly dynamic, and being able to distinguish natural fluctuations from precipitous local and regional declines should enable wildlife and habitat managers to respond appropriately. Monitoring birds at leks is important for population monitoring, and the framework presented here provides a mechanism for using a collection of observations to assess local and regional population trends.

Topics: effect distances or spatial scale, population estimates or targets 
Coates, P.S., Ricca, M.A., Prochazka, B.G., Brooks, M.L., Doherty, K.E., Kroger, T., Blomberg, E.J., Hagen, C.A., and Casazza, M.L., 2016, Wildfire, climate, and invasive grass interactions negatively impact an indicator species by reshaping sagebrush ecosystems: Proceedings of the National Academy of Sciences of the United States of America, v. 113, no. 45 , p. $12745-12750$.

DOI: https://doi.org/10.1073/pnas.1606898113

Background: Wildfire and invasive annual plants are ecosystem threats to sagebrush ecosystems which can affect GRSG populations through changes in habitat condition and availability. This paper reports research and applications that are also discussed by Coates, Ricca, and others (2015), also summarized in this report.

Objectives: The study objective was to investigate the long-term relations between GRSG population growth rates, wildfire occurrences, precipitation, and invasion by cheatgrass over a 30 -year period across the Great Basin.

Methods: The authors developed a Bayesian model that incorporated GRSG counts from leks, density dependence, previous-year precipitation, cumulative burned area in proximity to leks, and potential for recovery after fire or invasion by cheatgrass (using sagebrush resistance and resilience mapping based on soil moisture and temperature gradients). The final model was used to test scenarios for management and investigate the effects on GRSG populations 30 years into the future.

Location: California, Idaho, Nevada, Oregon, Utah; MZ II, MZ III, MZ IV, MZ V

Findings: Cumulative burned area had a chronic, negative effect on GRSG populations, which was attributed to habitat conversion resulting from cheatgrass invasion. Cheatgrass invasion after fire is very common and highly probable in the Great Basin, where soil-climate conditions create low sagebrush resistance and resilience. Precipitation had a positive influence on the subsequent year's population growth rate of GRSG. However, in areas with increased wildfire, positive effects of precipitation were nullified and populations experienced long-term declines. The authors projected a 43 percent decline in GRSG in the Great Basin by 2044 if current trends of wildfire continue unabated, and models predicted that a 75 percent reduction in the rate of cumulative burned area would be needed to prevent further GRSG declines.

Implications: Cumulative burned area has multiple negative effects on GRSG population dynamics. The direct effect of habitat loss, especially when the post-burn environment is dominated by cheatgrass, was associated with GRSG population decline. Further, when the burned area is large, GRSG population dynamics are decoupled from precipitation-driven cycles that are characteristic of the species range-wide. Wildfire suppression and increased protection coupled with active post-fire restoration will likely be needed to reduce the rate of cumulative burned area by 75 percent.

Topics: behavior or demographics, broad-scale habitat characteristics, fire or fuel breaks, nonnative invasive plants, weather and climate 
Coates, P.S., Ricca, M.A., Prochazka, B.G., Doherty, K.E., Brooks, M.L., and Casazza, M.L., 2015, Long-term effects of wildfire on greater sage-grouse-Integrating population and ecosystem concepts for management in the Great Basin: U.S. Geological Survey OpenFile Report 2015-1165, 42 p.

DOI: https://doi.org/10.3133/ofr20151165

Background: Management of sagebrush ecosystems includes a focus on management for resilience to wildfire and resistance to invasion by nonnative annual grasses. Understanding how GRSG populations respond to wildfire, ecosystem recovery from wildfire, and potential interactions between climate and wildfire across broad areas can inform GRSG conservation efforts.

Objectives: The researchers sought (1) to model GRSG population dynamics using precipitation and wildfire data and considering density-dependent effects, (2) to make projections of future population trends based on fire and ecosystem recovery from fire, and (3) to evaluate how fire management goals may affect GRSG population trends.

Methods: The authors used lek counts from 1985 to 2013 across the Great Basin (1,770 leks), records of fires that occurred within 10 kilometers of those leks, and precipitation data to relate GRSG abundance to habitat conditions over the 30 -year study period. Population density effects were accounted for in population models. The authors partitioned the landscape according to the sagebrush resistance and resilience classification (based on soil-moisture and temperature gradients) to differentiate post-fire recovery rates, and they characterized fires using distance to lek, burned area, and the ratio of fire perimeter to area.

Location: California, Idaho, Nevada, Oregon, Utah; MZ II, MZ III, MZ IV, MZ V

Findings: Burned area was inversely related to the amount of precipitation across the Great Basin. The area burned within low-resistance and low-resilience areas of sagebrush was consistently greater than for moderate and high sagebrush resistance and resilience classes. The annual GRSG population rate of change increased with increasing distance from a fire and decreased with increasing cumulative burned area. Model interactions indicated that increased precipitation was correlated with GRSG population increase, but the effect was reversed (and GRSG populations declined) when the cumulative burned area was large.

Implications: This study demonstrated that chronic effects of slow to no recovery of sagebrush following wildfire, coupled with increasing wildfire frequency and size, are adversely affecting GRSG populations. Model results from the fire management scenarios indicated that a 75 percent reduction in the current annual rate of cumulative burned area would halt widespread population declines caused by wildfire. The accumulation of burned areas within the Great Basin drove predictions of 22-69 percent declines in GRSG populations. The beneficial effect of high precipitation that largely drives GRSG population cycles was also nullified with increased cumulative burned area, which led to long-term declines in populations affected by degraded habitat conditions from wildfire. 
Topics: behavior or demographics, broad-scale habitat characteristics, effect distances or spatial scale, fire or fuel breaks, non-native invasive plants, weather and climate 
*2019 Update* Coates, P.S., Wann, G.T., Billette, G.L., Ricca, M.A., Prochazka, B.G., 2019, Estimating sightability of Greater Sage-grouse at leks using an aerial infrared system and $\mathrm{N}$-mixture models. Wildlife Biology, 2019: wlb.00552, p. 1-11.

DOI: https://doi.org/10.2981/wlb.00552

Background: GRSG populations are often monitored by counting birds present at lek sites. However, these lek-counts can produce biased population estimates because observers typically do not detect all birds present during the survey.

Objectives: The goal of this study was to estimate sightability, the proportion of available individuals which are actually observed during lek-count surveys and to determine which environmental factors influence sightability.

Methods: The authors placed known numbers of captive raised ring-necked pheasants at pseudolek sites and then conducted aerial integrated infrared imaging system (AIRIS) surveys to determine the sightability rate of this GRSG-surrogate when using AIRIS. Estimating this rate allowed researchers to later use AIRIS to better estimate the "true" number of GRSG at leks. Next, GRSG were counted at leks using concurrent ground-based visual (GBV) and AIRIS surveys, where AIRIS count data, corrected for sightability, were used as "truth." This allowed the researchers to estimate GBV-based sightability rates.

Location: California, Idaho, Nevada; MZ III, MZ IV, MZ V

Findings: At pseudo-leks, AIRIS detected 93 percent of birds. Using this information, the authors calculated that GBV surveys detected about 86 percent of birds at leks. Thus, GBV surveys underestimate male lek attendance by about 14 percent. The authors found that sagebrush cover negatively affected sightability for GBV counts, but not for AIRIS counts. Researchers also found that sightability estimates were similar using repeated GBV counts within an $\mathrm{N}$-mixture model framework.

Implications: Using AIRIS surveys resulted in greater sightability rates than GBV methods. The authors suggest that relying on maximum lek counts from a GBV lek surveys are likely to result in population estimates about 14 percent lower than true values, and even lower in areas with high sagebrush cover. Researchers provide generalized correction values that can be applied to GBV and AIRIS methods to better estimate true numbers of birds on leks. Alternatively, estimating sightability using multiple counts within a single morning can also improve estimates.

Topics: population estimates or targets 


\section{Conover, M.R., and Roberts, A.J., 2016, Declining populations of greater sage-grouse- Where and why: Human-Wildlife Interactions, v. 10, no. 2, p. 217-229.}

DOI: https://doi.org/10.26077/1xh9-wv56

Background: This paper provides an overview and assessment of a suite of issues affecting population trends.

Objectives: This paper examined several factors that may affect long-term trends in GRSG populations, including hunting, predators, parasites and disease, loss of sagebrush habitat, reduction in foods for chicks, reduction in foods for adults, oil and gas development, livestock grazing, fences, and power lines.

Methods: The authors provided a historical and scientific review of factors that affect GRSG population dynamics and interpreted the relative influence these factors may have on GRSG populations.

Location: range-wide; MZ I, MZ II, MZ III, MZ IV, MZ V, MZ VI, MZ VII

Findings: Hunting may have an additive effect on GRSG mortality in some areas, but low harvest rates and control by State agencies suggest minimal effects of hunting on population numbers. While predation of GRSG is important, existing data do not indicate a change in predation rates over time except for the recent increase in common ravens, which are nest predators. West Nile virus has killed many GRSG, but it appears that natural resistance is increasing. While food availability is sustained in many areas, the loss of large patches of sagebrush because of human development and modification is strongly connected to GRSG population declines. Decline in quality of seasonal habitats, especially brood-rearing and wintering habitat, was recognized as a contributor to population decline. GRSG behavioral responses to energy development and infrastructure contribute to habitat reduction and fragmentation. Although livestock can have detrimental effects on habitat conditions, variability in grazing practices and GRSG response to grazed habitats makes generalizable conclusions difficult.

Implications: Human population increase and associated conversion of sagebrush ecosystems were cited as the most important factor associated with GRSG declines. Large wildfires often exacerbate this problem by removing sagebrush, which is typically slow to recover after fire. Protection and restoration of large patches of sagebrush habitat were cited as the most important management action.

Topics: energy development, fences, fire or fuel breaks, herbivory/grazing, hunting, infrastructure (roads, pipelines, powerlines, cell towers), population estimates or targets, predators or predator control, site-scale habitat characteristics 


\section{Conover, M.R., and Roberts, A.J., 2017, Predators, predator removal, and sage-grouse-A review: Journal of Wildlife Management, v. 81, no. 1, p. 7-15.}

DOI: https://doi.org/10.1002/jwmg.21168

Background: Predation affects GRSG populations, but the influence of predation on GRSG population trends is not clear and may not be significant. Predator control is considered to be a management option for increasing GRSG populations, but target species and effectiveness are uncertain.

Objectives: The authors reviewed literature spanning several decades and compiled observations to document types of predators, predation rates, and effects of predator control on GRSG.

Methods: The authors described current knowledge regarding predation of GRSG nests, juveniles, and adults, including an evaluation of predator removal, based on the published literature and direct surveys of biologists.

Location: The geographic range of the literature search is unclear, but it is likely broad.

Findings: Data from 117 adult GRSG fatalities indicated that eagles, owls, and coyotes kill most adults. Other predators include falcons, goshawks, red foxes, bobcats, badgers, and mink. Records for 44 juvenile fatalities indicated 16 predator species, including eagles, hawks, goshawks, harriers, falcons, weasels, coyotes, red foxes, bobcats, badgers, rattlesnakes, and gopher snakes. Nest depredation was predominantly by ravens, badgers, and coyotes, but also included destruction by magpies, red foxes, bobcats, weasels, gopher snakes, elk, sheep, and cattle. Too few studies of predator control have been conducted to conclude that predator removal increases GRSG juvenile or adult survival, but nest success may be higher when ravens are removed or have low densities. Removal of ravens and coyotes has been studied specifically, but removal of other species has not.

Implications: Based on GRSG population trends, the timing of GRSG population declines, and estimates of predator populations, the authors concluded that predation is not a likely factor in range-wide GRSG trends, with the exception of ravens in recent years. Limitations of research designs and replication make clear inferences difficult, even in the case of nest depredation where more reliable evidence exists.

Topics: population estimates or targets, predators or predator control 


\section{Cook, A.A., Messmer, T.A., and Guttery, M.R., 2017, Greater sage-grouse use of mechanical conifer reduction treatments in northwest Utah: Wildlife Society Bulletin, v. 41, no. 1, p. 27-33.}

DOI: https://doi.org/10.1002/wsb.742

Background: Encroachment of pinyon pine and juniper into sagebrush ecosystems is recognized for reducing GRSG habitat use and may be associated with GRSG population declines in some areas.

Objectives: The authors sought (1) to determine effects of conifer removal treatments on GRSG habitat use and (2) to identify local and landscape factors affecting GRSG use of treated and untreated areas.

Methods: The authors used telemetry (123 GRSG) and scat surveys to assess use of 16 conifer treatments by GRSG from 2012 to 2013 in a landscape that included a mix of land ownerships, land management, livestock grazing, agriculture, and conifer encroachment. Treatments were all mechanical and ranged in size from 57 to 547 hectares. Habitat patterns were assessed at four spatial scales from 40 meters $(\mathrm{m})$ to 2 kilometers $(\mathrm{km})$.

Location: Utah; MZ IV

Findings: Use of treatment sites by GRSG was positively associated with agriculture within 1 $\mathrm{km}$ of treatments and negatively associated with conifer cover within $500 \mathrm{~m}$ of treatments. Presence of sagebrush cover and of mesic habitats were also positively but weakly associated with GRSG use. Mechanical treatments all retained some sagebrush cover, but GRSG use was not observed in all treatments. GRSG use of treatment areas increased with treatment age but was unrelated to treatment size or proximity to water.

Implications: Proximity of mechanical conifer treatments to adjacent, desirable habitats was a determinant of GRSG use of treated areas. Treatment areas in the study exhibited vegetation characteristics known to be important for GRSG and may have increased available GRSG habitat by decreasing conifer canopy cover. However, understanding treatment effects on GRSG populations will require further study. The presence of sagebrush cover, mesic habitats, and select types of agriculture (which may function as surrogate mesic brood habitat in the study area) within $1 \mathrm{~km}$ were positively associated with GRSG habitat use, which can help inform future plans for conifer removal treatments.

Topics: agricultural conversion, broad-scale habitat characteristics, conifer expansion, effect distances or spatial scale, habitat selection, site-scale habitat characteristics 


\title{
Creutzburg, M.K., Henderson, E.B., and Conklin, D.R., 2015, Climate change and land management impact rangeland condition and sage-grouse habitat in southeastern Oregon: AIMS Environmental Science, v. 2, no. 2, p. 203-236.
}

\author{
DOI: https://doi.org/10.3934/environsci.2015.2.203
}

Background: Annual grass invasion and conifer expansion, among other factors, have been associated with landscape-level changes in sagebrush ecosystems. Climate change and likely increases in wildfires may exacerbate existing stressors to sagebrush ecosystems and possibly may provide some sagebrush restoration opportunities.

Objectives: This study sought to investigate relations between future climate scenarios, ecosystem dynamics, and habitat restoration to project potential effects on rangeland and GRSG habitat across the landscape in eastern Oregon.

Methods: The researchers used a combination of state and transition models, climate envelope models, and dynamic global vegetation models to evaluate four climate scenarios and three management scenarios (no management, current management, GRSG habitat restoration management under a hypothetical budget increase). Climate-informed state and transition models were developed to integrate potential changes in vegetation, fire regimes, and habitat conditions under different scenarios. A classification tree was used to classify GRSG locations from leks and telemetry (source and amount not identified) based on climate conditions (precipitation and temperature).

\section{Location: Oregon; MZ IV, MZ V}

Findings: Changes in habitat type distribution were projected for future climate scenarios as an increase in moist shrub steppe and a decrease in dry shrub steppe. The extent of xeric shrub steppe varied from large decreases to increases among scenarios. Wildfire occurrence increased with all climate scenarios. Management treatments had little effect on annual grass abundance but were deemed effective for controlling conifer invasion of shrub steppe. The modeled scenarios suggested initial decline in GRSG habitat, but they diverged and often suggested increased habitat later in this century.

Implications: Management actions were effective at reducing loss of GRSG habitat resulting from juniper expansion, but they were not effective in controlling invasive annual grass. Increasing moist shrub steppe under future climate scenarios was accompanied by increased potential for conifer expansion. The interaction of invasive annual grasses and wildfire remained a problem for dry shrub steppe into the future, but wildfire in moist shrub steppe aided in preventing juniper expansion into shrub steppe. Uncertainty in climate model projections indicated potential for large differences in GRSG habitat distribution and condition, depending on future climate.

Topics: broad-scale habitat characteristics, conifer expansion, fire or fuel breaks, habitat restoration or reclamation, non-native invasive plants, weather and climate 
*2019 Update* Crist, M.R., Chambers, J.C., Phillips, S.L., Prentice, K.L., and Wiechman, L.A., eds, 2019, Science framework for conservation and restoration of the sagebrush biome: Linking the Department of the Interior's Integrated Rangeland Fire Management Strategy to long-term strategic conservation actions. Part 2. Management applications. Gen. Tech. Rep. RMRS-GTR-389. Fort Collins, CO: U.S. Department of Agriculture, Forest Service, Rocky Mountain Research Station. 237 p.

DOI: https://doi.org/10.2737/RMRS-GTR-389

Background: This is Part 2 in a series of reports designed to link the Department of Interior's Integrated Rangeland Fire Management Strategy to conservation actions in the sagebrush biome.

Objectives: The goal of this report is to help resource managers take the scientific information and decision-support tools presented in Part 1 and apply them to facilitate rangeland habitat management.

Methods: The report describes implementation of concepts including: adaptive management and monitoring, climate adaptation, wildfire and vegetation management, nonnative invasive plant management, application of National Seed Strategy concepts, livestock grazing management, wild horse and burro management, and consideration of tradeoffs.

Location: range-wide; MZ I, MZ, II, MZ III, MZ IV, MZ V, MZ VI, MZ VII

Findings: Topics covered in this report and the geospatial data, maps, and models to which the report is linked, can provide valuable information for resource managers implementing habitat management in the sagebrush biome.

Implications: The strategic, long-term, multiscale approaches described in this report, as well as associated tools, will aid resource managers in implementing on-the-ground management actions in the sagebrush biome.

Topics: agricultural conversion, broad-scale habitat characteristics, conifer expansion, energy development, ex-urban development, fire or fuel breaks, habitat restoration or reclamation, herbivory/grazing, infrastructure (roads, pipelines, powerlines, cell towers), mining, new geospatial data, non-native invasive plants, population estimates or targets, recreation, sagebrush removal, weather and climate, wild horses and burros 


\section{Crist, M.R., Knick, S.T., and Hanser, S.E., 2015, Range-wide network of priority areas for greater sage-grouse-A design for conserving connected distributions or isolating individual zoos?: U.S. Geological Survey Open-File Report 2015-1158, 34 p.}

DOI: https://doi.org/10.3133/ofr20151158

Background: Successful GRSG conservation reserve design should consider connectivity analyses to recognize the importance of individual habitat priority areas designated by States in promoting movement among populations across the GRSG range. Similar information was later addressed by Crist and others (2017), also summarized in this report.

Objectives: In this study, the authors (1) mapped habitat distribution across the GRSG range, (2) identified important priority areas based on habitat connections, (3) analyzed the role of each priority area in maintaining connectivity across habitat network clusters, and (4) modeled potential isolation of priority areas based on landscape context.

Methods: The authors used graph theory and centrality indices to analyze connectivity between identified priority areas and potential isolation of some areas or populations.

Location: range-wide; MZ I, MZ II, MZ III, MZ IV, MZ V, MZ VI, MZ VII

Findings: Important priority areas and movement corridors may provide multiple connections among neighboring habitats or an important bridge across a landscape otherwise resistant to GRSG movement. The analysis identified important priority areas for maintaining population movements based on network connectivity analyses and also identified isolated areas. Some portions of the GRSG range were dependent on a few priority areas to ensure connectivity of the populations. A large portion of the GRSG range comprises many smaller priority areas contained within a large priority area network that increase overall connectivity. Important movement corridors and potential pinch points across the range-wide network were identified.

Implications: Connectivity of habitats and populations is important for population movements, genetic exchange, and recolonization of habitats. Long-distance movements of GRSG have been documented, but risk associated with the landscapes that the birds traverse is not well understood. The current designated priority area strategy does not protect movement corridors among priority areas, and some areas may be at risk of isolation even when they are not separated by large distances. Several large, highly connected areas exist within the range. These areas are likely essential to GRSG conservation success over the long term.

Topics: behavior or demographics, broad-scale habitat characteristics, effect distances or spatial scale, new geospatial data 


\section{Crist, M.R., Knick, S.T., and Hanser, S.E., 2017, Range-wide connectivity of priority areas for greater sage-grouse-Implications for long-term conservation from graph theory: The Condor, v. 119, no. 1, p. 44-57.}

DOI: https://doi.org/10.1650/CONDOR-16-60.1

Background: This paper presents a broad-scale analysis of the distribution of GRSG habitats and connectivity among habitats. Habitat loss and fragmentation from multiple causes have been associated with GRSG population declines. Similar information was addressed by Crist and others (2015), also summarized in this report.

Objectives: Study objectives were to investigate (1) the importance of different habitat priority areas identified by States and their configuration in creating a connected habitat network for GRSG, (2) the implications of spatial structure of priority areas in $m$ aintaining connected GRSG populations, and (3) the potential for isolation of priority areas because of a lack of habitat connectivity.

Methods: The authors evaluated connectivity of priority habitats within the Bi-State, Central, and Washington regions based on the distribution of priority areas and an understanding of GRSG movements across their range. Habitat suitability developed in a previously published study was used to define landscape conditions affecting GRSG movements. Graph theory was used to identify movement corridors connecting habitat areas and to understand how the spatial pattern of priority areas function with respect to GRSG movements and survival.

Location: range-wide; MZ I, MZ II, MZ III, MZ IV, MZ V, MZ VI, MZ VII

Findings: Network analysis provides insights into connections between habitats and the potential for isolation of populations because of the inability of animals to move across the landscape. Priority areas may be isolated because of a lack of connected habitat among them, as observed for habitats of the Bi-State and Washington GRSG populations. Connectivity across the priority areas, when analyzed as a network, often depended on a few priority areas, elevating the importance of these areas for conserving populations.

Implications: Habitat loss in priority areas and movement corridors that function as links among priority areas may have important implications for managing GRSG populations across their range. The ability for birds to move among habitats has implications for genetic exchange and recolonization of suitable habitats. Priority areas with limited connectivity may still provide important habitat contributions and may play an important role in dynamics of GRSG populations. Conserving connectivity among priority areas may remove the risk of isolating populations in priority areas and increase the capacity of priority areas to maintain populations over the long term.

Topics: behavior or demographics, broad-scale habitat characteristics, effect distances or spatial scale, new geospatial data 


\section{Cross, T.B., Naugle, D.E., Carlson, J.C., and Schwartz, M.K., 2016, Hierarchical population structure in greater sage-grouse provides insight into management boundary delineation: Conservation Genetics, v. 17, no. 6, p. 1417-1433.}

DOI: https://doi.org/10.1007/s10592-016-0872-z

Background: Geographic isolation created by habitat fragmentation and isolation of populations may cause genetic isolation in some GRSG populations. Current understanding of GRSG genetic population structure is limited, but it may be important for population viability.

Objectives: The study objectives were (1) to quantify GRSG population structure and gene flow, (2) to compare existing management group boundaries to genetic population structure, (3) to characterize gene flow among management groups, and (4) to initiate exploration of the relation between population structure and major landscape features.

Methods: Using 3,481 feather and blood samples collected from 2009 to 2012, the authors quantified genetic characteristics of GRSG using 15 microsatellite loci. Samples were collected from 351 leks, and spatial reference information was maintained to enable analysis of spatial patterns of genetic characteristics.

Location: Montana, North Dakota, South Dakota; MZ I, MZ IV

Findings: Genetic structure was found to be shaped by geography — west to east and north to south. The genetic structure was used to define three separate genetic subpopulations. Secondary population subdivision was also described within two of the three subpopulations, indicating local divergence. The subpopulations occupied different elevations and areas dominated by different species of sagebrush. Genetic relatedness among individuals was largely governed by distance up to approximately 240 kilometers.

Implications: Genetic similarities among subpopulations indicated that genes distributed by individual dispersal have led to genetic mixing over large distances. Current priority areas are well aligned with protection of the subpopulations identified. The authors suggest that genetic subpopulations could be used to define management groups for purposes such as assessing connectivity, translocating individuals, or regulating harvest.

Topics: behavior or demographics, genetics, population estimates or targets 


\section{Cross, T.B., Naugle, D.E., Carlson, J.C., and Schwartz, M.K., 2017, Genetic recapture identifies long-distance breeding dispersal in greater sage-grouse (Centrocercus urophasianus): The Condor, v. 119, no. 1, p. 155-166.}

DOI: https://doi.org/10.1650/CONDOR-16-178.1

Background: Movement and dispersal of GRSG is a common topic, but little is known about movements between leks during the breeding season (breeding-season dispersal). Both female and male birds have been known to visit multiple leks during a single season, but most individuals are thought to return to the same lek each spring throughout their lifetime.

Objectives: The authors sought to quantify breeding-season dispersal (1) to evaluate patterns of lek fidelity, (2) to identify distances and frequencies of movements between leks, (3) to compare differences in movements between females and males, and (4) to examine relative costs of breeding-season dispersal using known mortalities.

Methods: This study used 7,629 genetic samples from feathers and blood collected during 20072013 from 763 leks to identify individuals using a 22 microsatellite panel.

Location: Idaho, Montana, North Dakota, South Dakota; MZ I, MZ IV

Findings: Of the 3,244 total genetic captures (individuals), only 80 were recaptures. Of the recaptures, half were at the same lek in a different year, and half were at a different lek in the same year or a different year. Two recaptured males were detected at three different leks, visiting leks 14 to 90 kilometers apart in the same year. A slight majority of movements between leks were within the same Priority Area for Conservation, but some birds moved outside, into or out of, or among priority areas. The frequency and distance of dispersal was not significantly different among sexes. Known mortalities were birds that had traveled significantly farther than average.

Implications: Lek fidelity was strong, with most GRSG returning to the same lek. Some birds, however, were highly mobile during breeding season. Breeding-season dispersal can have important effects on genetic structure of populations. GRSG genetic population structure is strongly affected by differences related to distance, but long-distance dispersal by a few individuals can have important effects on genetic mixing and diversity. Because some GRSG dispersed outside of priority areas, understanding connections and resistance to dispersal at the landscape level provide important insights into relations among distant populations.

Topics: behavior or demographics, genetics, population estimates or targets 


\section{*2019 Update* Cross, T.B., Schwartz, M.K., Naugle, D.E., Fedy, B.C., Row, J.R., and Oyler- McCance, S.J., 2018, The genetic network of greater sage-grouse: range-wide identification of keystone hubs of connectivity: Ecology and Evolution, v. 8, no. 11, p. 5394-5412.}

DOI: https://doi.org/10.1002/ece3.4056

Background: GRSG depend on connectivity to breeding sites and other spatially discrete areas for seasonal habitat and for gene flow. Genetic networks can depict complicated genetic relationships between individuals, highlighting areas or "keystone hubs" that are most important to GRSG connectivity range-wide.

Objectives: The authors' goal was to assess which areas are most important for GRSG genetic connectivity across the species' range.

Methods: Genotyping was conducted on nearly 6,000 individual GRSG from 1,200 leks spanning the species' range and a genetic network was constructed depicting hubs - nodes important to gene flow, and spokes - nodes where connectivity depends on hubs.

Location: range-wide; MZ I, MZ II, MZ III, MZ IV, MZ V, MZ VI, MZ VII

Findings: Hubs and keystone nodes were detected throughout the contiguous portion of the species' range, but those of the greatest importance tended to occur in the center, for example, in much of Wyoming and eastern Idaho. Genes were readily exchanged in Montana, northern Wyoming, Utah, and eastern Nevada nodes.

Implications: Maintaining hubs and keystone nodes are important for GRSG connectivity, gene flow, and resilience. The loss of these habitats or populations could reduce gene flow and diversity disproportionately across the species' range.

Topics: genetics, new geospatial data 


\section{Curran, M.F., Crow, T.M., Hufford, K.M., and Stahl, P.D., 2015, Forbs and greater sage-grouse habitat restoration efforts-Suggestions for improving commercial seed availability and restoration practices: Rangelands, v. 37, no. 6, p. 211-216.}

DOI: https://doi.org/10.1016/j.rala.2015.10.007

Background: Habitat restoration is a component of GRSG conservation efforts and may be included in land management plans. Forbs are seasonally important for GRSG diets, but limited information and limited seed availability may hinder restoration from including suitable forbs.

Objectives: The authors sought (1) to develop a list of forb genera and species that are preferred by GRSG, (2) to describe availability of seeds for these species, and (3) to make recommendations for restoration projects based on this information.

Methods: The authors reviewed literature and the current state of knowledge to describe forb species eaten by GRSG chicks (Idaho, Montana, Oregon) and brooding hens (Oregon). Authors then searched the Native Seed Network (http://nativeseednetwork.org/) for availability of identified forb seed.

Location: Idaho, Montana, Oregon; MZ I, MZ IV, MZ V

Findings: The authors identified 29 genera of forbs, including both native and introduced species and annual, biennial, and perennial species. Differences in the species available and selected by GRSG likely vary by region and habitat, but specific information on biogeography of diets was not available. Restoration and reclamation plans often do not specify native forb seed mixes.

Implications: Use of native forbs for habitat restoration could improve habitat values for GRSG. While considerable uncertainty remains about the composition of forbs that GRSG use, a few lists are available, and 53 percent of those forbs identified are available commercially. Additional research on biogeography of forbs and GRSG diets is needed to better inform habitat restoration using forbs.

Topics: habitat restoration or reclamation 


\section{*2019 Update* Cutting K.A., Rotella J.J., Schroff S.R., Frisina M.R., Waxe J.A., Nunlist E., and Sowell B.F., 2019, Maladaptive nest-site selection by a sagebrush dependent species in a grazing-modified landscape: Journal of Environmental Management, v. 236, no. Epub 2019, p. 622-630.}

DOI: https://doi.org/10.1016/j.jenvman.2019.01.085

Background: In human-modified landscapes, animals may paradoxically select habitats that lead to decreased survival or fitness. This "maladaptive selection" arises largely because animals may undervalue high-quality locations, which may appear less attractive than lower quality human-modified habitats such as those near agricultural infrastructure. It is unclear if agricultural resources alter the cues used by GRSG to identify quality habitats where survival is relatively high.

Objectives: The objective of this study was to determine how sagebrush characteristics, livestock grazing and associated infrastructure, and other biotic and abiotic habitat characteristics influence female GRSG nest site selection and subsequent nest survival.

Methods: For each of three years, 51-57 female GRSG from 10 leks were tracked and nest sites were monitored for habitat conditions and chick survival. Nest habitat characteristics were compared to those of random locations and nest survival rate was modeled as a function of habitat and agriculture variables.

\section{Location: Montana; MZ IV}

Findings: The authors found evidence of maladaptive nest-site selection, as nest survival in the most-preferred sagebrush type was 25 percent lower than the survival rate observed in avoided habitat types. Nest survival was substantially greater in locations farther from fence lines, with lower cow pie densities, and with greater live grass cover and less dead grass cover.

Implications: These findings suggest that certain sagebrush habitats may function as ecological traps, whereas others may be undervalued, especially in an actively grazed setting. Additional fencing in these locations may lower GRSG nest survival rates.

Topics: behavior or demographics, broad-scale habitat characteristics, effect distances or spatial scale, fences, habitat selection, herbivory/grazing, range mgmt. structures (water developments, mineral licks), site-scale habitat characteristics, survival 


\section{Dahlgren, D.K., Guttery, M.R., Messmer, T.A., Caudill, D., Elmore, R.D., Chi, R., and Koons, D.N., 2016, Evaluating vital rate contributions to greater sage-grouse population dynamics to inform conservation: Ecosphere, v. 7, no. 3, article e01249, 15 p.}

DOI: https://doi.org/10.1002/ecs2.1249

Background: Little is known about how key GRSG vital rates influence GRSG populations over the long term. Models of demographic response to perturbation and environmental variability can inform conservation efforts.

Objectives: The authors sought (1) to evaluate the effect of GRSG vital rates on a GRSG population and (2) to determine if current management practices are effectively conserving GRSG.

Methods: One hundred and eighty female GRSG were radio-marked and monitored over a 12year period. Nesting activities, nest fate, clutch size, chick survival, and female survival were measured. Population models assessed the contribution to population growth rate from vital rates of daily nest survival, chick and brood survival, and survival probability of females across years and by two age classes. For each year of the study, female-based vital rates were used to model population growth rates, which were then deconstructed rate by rate to predict the effects of vital rate variation on the population. Population growth rates were also estimated from male lek count data collected between 1998 and 2009.

Location: Utah; MZ III

Findings: The GRSG population was stable and had stable age distributions throughout the study. Population growth rates were similar, whether measured from female- or male (lek)-based data. Survival of females, from juvenile through after their second year, had the greatest effect on population size, more so than reproductive rates.

Implications: Lek counts, which are less costly than female studies, can reliably estimate changes in GRSG populations, and telemetry studies are useful for demographic monitoring. In combination, these two methods can be used to measure life-cycle dynamics. Results suggest that GRSG females can exploit varying environmental conditions and may respond to management actions, whereas nest survival is highly variable and more affected by natural environmental variation.

Topics: behavior or demographics, survival 


\section{Dahlgren, D.K., Larsen, R.T., Danvir, R., Wilson, G., Thacker, E.T., Black, T.A., Naugle, D.E., Connelly, J.W., and Messmer, T.A., 2015, Greater sage-grouse and range management- Insights from a 25-year case study in Utah and Wyoming: Rangeland Ecology and Management, v. 68, no. 5, p. 375-382.}

DOI: https://doi.org/10.1016/j.rama.2015.07.003

Background: The effectiveness of placing mosaics of small-scale shrub removal treatments across large areas for improving GRSG habitat is unknown. However, long-term case studies of treatment outcomes can inform managers when experimental data and statistical replication are lacking.

Objectives: The authors described (1) how GRSG populations responded over 25 years to different large-scale management actions done on a private ranch that created habitat mosaics and (2) how a retroactive case study can inform management and devise testable future hypotheses.

Methods: The authors analyzed approximately 25 years of lek count and brood size data, as well as various data of GRSG use of intact sagebrush and of plots that received shrub cover reduction treatments. The research encompassed three large study areas in proximity to one another that had similar environmental conditions and sagebrush community types. The study areas differed, however, in land ownership, grazing management, sagebrush removal, well density, and treatment type and size. Pastures on the focus ranch generally experienced higher livestock densities, shorter grazing periods, and longer periods of rest before regrazing. Sagebrush canopy control treatments implemented on the ranch during this time included the use of aerators, disks, chain harrows, herbicide, and prescribed fire and were designed to create small-scale mosaics in mid- to high-elevation vegetation communities with increased edge and herbaceous plant cover. GRSG surveys in treated areas were conducted in the summers of some years and compared to results from nearby untreated reference sites.

Location: Utah, Wyoming; MZ II

Findings: During the study period, lek attendance on all three study areas initially decreased together. Following initiation of sagebrush treatments and with continuation of intensively managed grazing (including growing season rest), the ranch had 15 years of nearly double the number of males per lek compared to adjacent lands until adverse weather brought GRSG counts back to adjacent levels. Surveys indicated more GRSG using sagebrush treatment areas compared to adjacent untreated reference locations, with most GRSG using areas near habitat edges.

Implications: Study observations led to multiple testable hypotheses about the role of sagebrush, herbaceous plants, weather variations, vegetation treatments, and grazing practices for GRSG. The authors recommended that, when planning for sagebrush treatments to benefit GRSG, managers consider seasonal use patterns; target treatments in large, intact sagebrush communities at mid to high elevations; design actions to create mosaics with as much edge as possible; encourage grazing practices that include growing season rest; and use an annual treatment rate that does not exceed the sagebrush recovery rate. 
Topics: behavior or demographics, habitat restoration or reclamation, herbivory/grazing, sagebrush removal, site-scale habitat characteristics

${ }^{*}$ A correction to this paper has been published. The correction affects interpretation of grazing intensity but does not change the Findings or Implications described here.

Dahlgren, D.K., Larsen, R.T., Danvir, R., Wilson, G., Thacker, E.T., Black, T.A., Naugle, D.E., Connelly, J.W., and Messmer, T.A., 2016, Corrigendum to 'Greater sage-grouse and range management-Insights from a 25year case study in Utah and Wyoming' [Rangeland Ecol Manag 68 (2015) 375-382]: Rangeland Ecology and Management, v. 69, no. 3, p. 235, https://doi.org/10.1016/j.rama.2016.01.004. 
Dahlgren, D.K., Messmer, T.A., Crabb, B.A., Larsen, R.T., Black, T.A., Frey, S.N., Thacker, E.T., Baxter, R.J., and Robinson, J.D., 2016, Seasonal movements of greater sage-grouse populations in Utah-Implications for species conservation: Wildlife Society Bulletin, v. 40, no. 2, p. 288-299.

DOI: https://doi.org/10.1002/wsb.643

Background: Utah's statewide plan to conserve GRSG designates Priority Areas for Conservation that were selected to protect all seasonal habitats for each population of GRSG. The authors investigated whether Utah's priority areas include breeding, summer, and winter habitats.

Objectives: This study asks (1) how the age, sex, and habitat availability of GRSG in Utah influence their seasonal movements. It also (2) assesses distances between seasonal habitats to recommend buffer zones for conservation and (3) identifies how many GRSG seasonal locations are encompassed in the priority areas.

Methods: Authors compiled location data for 1,696 GRSG across Utah from 1998 to 2013 and classified GRSG populations as being associated with either large continuous or small isolated sagebrush landscapes. They collected telemetry data on adult GRSG nesting, brooding, and nonbreeding locations throughout the state. They recorded nest success and brooding, live chick, lek, and nonbreeding adult locations for resident and translocated GRSG and evaluated sagebrush habitat extents and vegetation cover types.

Location: Utah; MZ II, MZ III, MZ IV, MZ VII

Findings: Females and their broods from larger populations in contiguous sagebrush moved more than those in smaller, isolated populations, but small populations moved farther from leks to winter grounds. Distances from nests to leks were consistent with other research, but nest success slightly increased with distance from leks. Priority Areas for Conservation captured 85 percent of seasonal locations from radio-marked birds.

Implications: Seasonal movements of Utah GRSG were generally lower than reported rangewide, likely because of fragmented sagebrush habitats. Management actions that increase the area of usable sagebrush may benefit Utah GRSG. Management plans can incorporate buffers based on, for example, observed distances between nests and leks to increase the conservation value of management actions. The authors recommended buffers of 5 and 8 kilometers between disturbed areas and GRSG breeding and summer habitats, respectively.

Topics: behavior or demographics, broad-scale habitat characteristics, new geospatial data, translocation 


\section{*2019 Update* Davee, R., Hannah, G., and Chamley, S., 2019, Using beaver dam analogues for fish and wildlife recovery on public and private rangelands in Eastern Oregon: Research Paper PNW-RP-617. Northwest Climate Hub, U.S Department of Agriculture, Forest Service, Pacific Northwest Research Station, p. 32.}

DOI: https://www.fs.usda.gov/treesearch/pubs/58234

Background: Beaver dam analogues (BDAs) have been found to improve habitat for fish and wildlife species, including GRSG. This has generated interest from land managers and private landowners regarding the use of BDAs for mitigation or restoration purposes.

Objectives: The objective of this report was to examine and summarize issues related to employing BDAs in western rangelands.

Methods: The authors reviewed and summarized research, legal, and policy documents related to beaver and BDA management. They also conducted interviews of relevant stakeholders.

Location: Oregon; MZ IV, MZ V, MZ VI

Findings: The authors found that regulations regarding BDA implementation are still being developed but permitting is often facilitated by local soil and water conservation districts. Funding agencies have begun offering financial support for BDA projects and beavers have recolonized agricultural lands following BDA construction. However, many ranchers are skeptical of restoring beaver populations on agricultural lands.

Implications: BDAs can improve habitat for fish and wildlife, including GRSG, but implementing this tool may require navigating new or yet-to-be established regulatory pathways. Obtaining buy-in from private landowners and ranchers is an important consideration for increasing implementation of this tool.

Topics: habitat restoration or reclamation, other topic, range mgmt. structures (water developments, mineral licks), site-scale habitat characteristics 
*2019 Update* Davies, K.W., and Bates, J.D., 2019, Longer-term evaluation of sagebrush restoration after juniper control and herbaceous vegetation trade-offs: Rangeland Ecology \& Management, v. 72, no. 2, p. 260-265.

DOI: https://doi.org/10.1016/j.rama.2018.10.006

Background: Encroachment of juniper trees into mountain big sagebrush communities reduces habitat for GRSG. Juniper trees can be readily removed, however re-establishing sagebrush on these sites is time-intensive and not always successful.

Objectives: The authors' goal was to determine if seeding mountain big sagebrush following juniper control speeds recovery in the long-term and how herbaceous vegetation is influenced through the recovery process.

Methods: Sagebrush cover was compared 7-8 years after juniper control - cutting and burning in areas that received subsequent sagebrush seeding to areas that were left unseeded. Pretreatment juniper stands were fully developed and generally lacked sagebrush.

Location: Oregon; MZ IV

Findings: After eight years, sagebrush cover was substantially greater in juniper control areas that were subsequently seeded than in locations that were left unseeded. Herbaceous cover, however, was lower in sagebrush-seeded areas than in comparable unseeded treatment areas.

Implications: Following juniper control in dense stands that lack sagebrush, mountain big sagebrush re-establishment is likely to be accelerated by seeding, whereas herbaceous vegetation cover may be reduced.

Topics: broad-scale habitat characteristics, conifer expansion, habitat restoration or reclamation 


\section{Davis, D.M., and Crawford, J.A., 2015, Case study-Short-term response of greater sage- grouse habitats to wildfire in mountain big sagebrush communities: Wildlife Society Bulletin, v. 39, no. 1, p. 129-137.}

DOI: https://doi.org/10.1002/wsb.505

Background: GRSG rely on native herbaceous plants growing under and around sagebrush. Understory plants were maintained historically by periodic low-intensity wildfires, but historical livestock grazing resulted in shrub dominance and an alteration of the natural fire regime. Prescribed fire in some sagebrush communities can temporarily increase forbs, but it can also negatively affect GRSG winter and nesting cover. Fire effects on GRSG habitat are poorly understood in higher elevation, more mesic mountain big sagebrush communities.

Objectives: The authors sought to identify the short-term $(<11$ year) response of GRSG nesting and brood-rearing habitats to wildfire by comparing herbaceous plants and ground-dwelling arthropods in burned and unburned sites.

Methods: Burned and unburned sites in two mountain big sagebrush communities were assessed during GRSG brood-rearing periods at 2-3 years and 10-11 years following wildfire. Vegetation characteristics that provided high-quality nesting and brood-rearing cover, plants known to provide forage for hens and chicks, and arthropod abundance were assessed for 2 years.

Location: northwestern Nevada; MZ V

Findings: Shrub cover decreased after wildfire, particularly $2-3$ years post-fire, but tall grass cover did not. Forb cover increased 2-3 years, but not 10-11 years, post-burn, but forb growth and phenology were not affected by wildfire. No changes to arthropod abundance after a fire were observed, but sample sizes were small. Burning did not stimulate the forbs that GRSG utilize. Wildfire did not affect cover of cheatgrass or native bunchgrasses.

Implications: In mountain big sagebrush communities where sagebrush is abundant, the understory is composed of adequate native perennial grasses and forbs, and invasive annual grasses are limited, prescribed burning may be a useful tool for improving GRSG nesting and brood-rearing habitat. The application of fire treatments in less mesic sagebrush communities with fewer forbs may not produce the desired results, which emphasizes that management decisions need to be made in light of existing conditions and documented GRSG seasonal habitat needs.

Topics: fire or fuel breaks, site-scale habitat characteristics 


\section{Davis, D.M., Reese, K.P., Gardner, S.C., and Bird, K.L., 2015, Genetic structure of greater sage-grouse (Centrocercus urophasianus) in a declining, peripheral population: The Condor, v. 117, no. 4, p. 530-544.}

DOI: https://doi.org/10.1650/CONDOR-15-34.1

Background: GRSG populations at the edge of the range in northeastern California have experienced declining numbers and fragmented habitats. Both factors may result in loss of genetic variation and dispersal-related gene flow and may negatively affect GRSG population viability.

Objectives: This study (1) examined the genetic structure of GRSG in northeastern California and (2) explored differences in sex-specific relatedness within leks and dispersal.

Methods: The authors collected data from 167 GRSG across 13 known leks throughout the study area over 3 years. The authors determined age, sex, and lek of capture and drew blood for DNA extraction. The study assessed genetic diversity within and between lek sites, spatial genetic structure, within-lek relatedness, and dispersal patterns.

Location: northeastern California; MZ V

Findings: The GRSG surveyed had genetic diversity similar to less isolated populations in the center of the range. Leks were not genetically differentiated, and no major population subdivisions were observed. GRSG in northeastern California are a single genetic population with evidence of gene flow between the leks, despite the fact that leks there are farther apart than those elsewhere across the GRSG range. Individuals at leks were largely unrelated to each other, and females had higher gene flow and greater dispersal distances than males.

Implications: The effects of fragmentation on genetic structure of a population can take considerable time to manifest. Although GRSG in northeastern California have maintained gene flow across the region to date, movement between leks there may become more disjunct, and GRSG there may face higher extinction rates if the leks become isolated. Connectivity will need to be preserved, habitat quality maintained, and gene flow considered in future conservation actions.

Topics: behavior or demographics, genetics 


\section{Decker, K.L., Pocewicz, A., Harju, S., Holloran, M., Fink, M.M., Toombs, T.P., and Johnston, D.B., 2017, Landscape disturbance models consistently explain variation in ecological integrity across large landscapes: Ecosphere, v. 8, no. 4, article e01775, 12 p.}

DOI: https://doi.org/10.1002/ecs2.1775

Background: Geospatial models of the effects of anthropogenic disturbances on wildlife and habitats are increasingly used for conservation and land management. These models are usually based on the distance to or density of disturbance, but model outputs are rarely validated against field data on habitat quality.

Objectives: The study objective was to compare a suite of three landscape disturbance models (general distance-based, GRSG distance-based, and GRSG density-based) to independent measures of habitat quality to assess model validity.

Methods: The authors used publicly available vegetation data to model changes in floristic quality across the landscape in order to validate the distance-based landscape integrity model. The landscape integrity model was based on the estimated effect and surface footprint of six types of anthropogenic disturbance: roads, ex-urban development, agriculture, mining, energy development infrastructure, and transmission structures. A value of zero in this model corresponded to no anthropogenic impact. The GRSG models were developed using similar methods and disturbance data, but they used values from the literature on the distances and densities at which the different types of disturbance affect GRSG. The authors used GRSG lek persistence and male abundance data (highest maximum male count recorded within the last 5 years) to validate the GRSG-specific disturbance models.

Location: Colorado; MZ II, MZ VII

Findings: Indices of floristic quality were lower in plots closer to disturbance (a negative relationship with the general distance-based landscape integrity model). Lek persistence and male abundance were also negatively related to both the GRSG-specific distance and density of disturbance models.

Implications: Indices of disturbance generated by geospatial models can be used to represent habitat quality in conservation planning for both general and species-specific applications. Choice of models for describing disturbance effects on GRSG can be driven by the scale and applications of the modeled information. Models can be useful in a variety of conservation applications, but they should be informed and validated by local information.

Topics: agricultural conversion, behavior or demographics, broad-scale habitat characteristics, effect distances or spatial scale, energy development, ex-urban development, infrastructure (roads, pipelines, powerlines, cell towers), mining, new geospatial data 


\section{Dettenmaier, S.J., Messmer, T.A., Hovick, T.J., and Dahlgren, D.K., 2017, Effects of livestock grazing on rangeland biodiversity-A meta-analysis of grouse populations: Ecology and Evolution, v. 7, no. 19, p. 7620-7627.}

DOI: https://doi.org/10.1002/ece3.3287

Background: Rangelands provide more than 70 percent of livestock forage globally, and global demands for livestock products are expected to increase. Livestock grazing may threaten some ground-nesting birds in rangelands, including grouse. The way grazing influences grouse species is poorly understood, despite considerable research on other aspects of their ecology.

Objectives: The authors conducted a systematic review of published literature to determine the current knowledge regarding effects of livestock grazing on grouse populations based on numbers of adults and fecundity.

Methods: The authors conducted a meta-analysis of previously published data on the relations between grouse population numbers, fecundity, and livestock grazing. The systematic review identified 5,637 publications that reported effects of livestock grazing on grouse, but only 4 that met criteria for inclusion in the meta-analysis. GRSG was one of 20 grouse species recognized, but the data assessed represented black grouse and red grouse, not GRSG.

Location: The geographic range of the literature search is unclear, but it is likely broad.

Findings: There is a paucity of published studies that measure the effect of livestock grazing on grouse vital rates. Only a few studies, from Europe and primarily focused on sheep grazing, empirically link livestock grazing to changes in vital rates. Based on these studies, the authors described a negative effect of livestock grazing on counts of adult grouse and chick production. Direct effects of grazing on grouse were not identified. Indirect effects on habitat condition were recognized as the most common effect. Overgrazing was recognized as a predominant cause of negative effects, but the effectiveness of best management practices was questioned.

Implications: Improper livestock grazing may have detrimental effects on the condition of habitats for grouse species, but effects of grazing on GRSG were not measured because no published studies exist on the effects of grazing on GRSG vital rates. Differences in grazing practices (for example, livestock type, stocking rates, and grazing regime) were recognized as important factors in determining potential beneficial, benign, or negative effects of grazing. The authors found that empirical assessments of the effect of livestock grazing on grouse vital rates are exceptionally limited and that considerable further research is needed to develop effective best management practices.

Topics: herbivory/grazing 


\section{Dinkins, J.B., Conover, M.R., Kirol, C.P., Beck, J.L., and Frey, S.N., 2016, Effects of common raven and coyote removal and temporal variation in climate on greater sage-grouse nesting success: Biological Conservation, v. 202, p. 50-58.}

DOI: https://doi.org/10.1016/j.biocon.2016.08.011

Background: Ravens and coyotes are GRSG nest predators, and both are lethally removed to protect livestock. Ravens are increasing with human development and have negative effects on nesting birds. Lethal removal of ravens may benefit GRSG, but lethal removal of coyotes could lead to mesopredator release, whereby smaller mammal predators, which are more efficient nest predators than coyotes, increase in abundance or distribution. Wetter weather conditions that promote vegetation growth around nests but increase predator olfaction may interact with declines in coyotes to influence GRSG nest success.

Objectives: The authors asked whether (1) changes in raven density and coyote abundance following removal efforts affected GRSG nest success and (2) weather conditions influenced these results for coyotes.

Methods: The authors selected 12 study sites in GRSG nesting habitat that were known to contain nesting hens and were within and beyond 15 kilometers of raven removal efforts. All 5 sites with raven removal also had coyote removal; 5 of 7 sites without raven removal had coyote removal. GRSG nest success was monitored during the 2008-2011 nesting seasons. Raven abundance following removal and number of coyotes removed were measured. Precipitation, temperature, and drought indices were extracted and compared to GRSG nest survival.

Location: Wyoming; MZ II

Findings: Predator removal efforts decreased raven density and increased GRSG nest survival over the study period. Cooler temperatures prior to nesting season were associated with increased nest success, likely the result of greater vegetation growth. The effect of precipitation occurring the week before nest hatch or fail on GRSG nest success was slightly positive in areas with no manipulation of coyotes. GRSG nest success was much lower in areas with more coyote removal and greater precipitation the week before nest failure.

Implications: Management of breeding and transient ravens may be a viable mitigation action in areas with high raven densities because it can reduce raven abundance and may increase GRSG nest success. However, long-term solutions, such as reducing supplemental food sources and perch structures, are necessary. Coyote removal likely results in lowered GRSG nest success because of the potential expansion of mesopredators (for example, badgers, skunks, and raccoons), which do better at smelling and thus locating and predating GRSG in wetter years.

Topics: behavior or demographics, predators or predator control, weather and climate 


\section{Dinkins, J.B., Lawson, K.J., Smith, K.T., Beck, J.L., Kirol, C.P., Pratt, A.C., Conover, M.R., and Blomquist, F.C., 2017, Quantifying overlap and fitness consequences of migration strategy with seasonal habitat use and a conservation policy: Ecosphere, v. 8, no. 11, article e01991, $14 \mathrm{p}$.}

DOI: https://doi.org/10.1002/ecs2.1991

Background: Though a combination of seasonal habitats are important for many GRSG, many conservation strategies focus on reproduction habitats. Evaluation of GRSG use of diverse habitats and associated implications for GRSG demographic rates is important to inform GRSG habitat conservation efforts.

Objectives: This research sought (1) to identify GRSG winter habitat use, (2) to quantify protection of these winter habitat areas by Core Areas, (3) to differentiate weather effects on winter use areas, (4) to compare nesting, brooding, and adult survival rates between GRSG that migrated to seasonal habitats and those that utilized the same areas for multiple seasons, and (5) to evaluate effects of weather on annual female survival.

Methods: The authors used telemetry data from 585 female GRSG from 2008 to $2015(9,180$ locations), spatial modeling, and survival models with spatial data representing habitat and climate conditions to assess annual and seasonal habitat use and survival.

Location: Wyoming; MZ II

Findings: Habitats protected by Wyoming's Core Areas overlapped GRSG summer habitats more than winter habitats, and average snow-water equivalent had little effect on the distribution of winter habitat use. Winter habitats were used by migratory and nonmigratory females, and migratory and nonmigratory birds had similar nest and brood success on average. Winter survival rates were higher than those in other seasons. Nest success and brood survival did not differ between areas inside compared to outside Core Areas. Temperature negatively and snowwater equivalent positively influenced adult female survival during the breeding season, but winter weather did not affect survival.

Implications: The importance of winter habitats was elevated by use by both migratory and nonmigratory females. Winter habitats were disproportionately outside of Core Areas, highlighting the greater potential for negative effects of anthropogenic uses on these important habitats. High survival and breeding success of female GRSG that did not migrate between seasons suggested that conservation of high-quality winter habitats could benefit GRSG in multiple seasons.

Topics: behavior or demographics, broad-scale habitat characteristics, habitat selection, survival, weather and climate 


\section{Dinkins, J.B., Smith, K.T., Beck, J.L., Kirol, C.P., Pratt, A.C., and Conover, M.R., 2016, Microhabitat conditions in Wyoming's sage-grouse core areas-Effects on nest site selection and success: PLoS ONE, v. 11, no. 3, article e0150798, 17 p.}

DOI: https://doi.org/10.1371/journal.pone.0150798

Background: Although GRSG consistently select sites with high sagebrush cover, the effects of sagebrush cover and microhabitat attributes on nest site selection and success are variable. Microhabitat availability across Wyoming's Core Areas varies and may relate to GRSG nest success and to effectiveness of the Core Area policy.

Objectives: This research sought to identify how GRSG nest site choices and nest success relate to microhabitat characteristics and availability within and outside of Wyoming's Core Areas.

Methods: The authors captured, aged, radio-marked, and monitored female GRSG from 2008 to 2014 across five sites in Wyoming and examined eggshells to evaluate nest success. The authors sampled multiple vegetation characteristics such as shrub and grass cover and height, gaps between shrubs, and forb cover to explain nest site characteristics and fate. Results were compared among 928 nests and 819 random locations within and outside of Core Areas.

Location: Wyoming; MZ II

Findings: GRSG chose concealed nest sites, those with more and taller big sagebrush, more shrub cover, more small gaps between shrubs, and more visual obstruction. Core Area microhabitats had more of the smaller gaps between shrubs than non-Core Area microhabitats, among other differences. Within Core Areas, GRSG selected sites with shorter sagebrush than outside of Core Areas. Nest success did not vary between sites within compared to outside of Core Areas. The top model of nest success indicated a positive relation between nest success and rock cover (mainly small diameter gravel) located 2.5-3.5 meters from nests.

Implications: Wyoming's Core Area policy is still relatively new and is focused on conservation at landscape scales (such as through limits on oil and gas development) rather than activities such as grazing that are more likely to affect conditions at the scale of nest microhabitats. Random points in non-Core Areas sampled here were also near Core Areas and often had not been subject to additional surface disturbance, potentially also contributing to the small differences observed between microhabitats inside compared to outside of Core Areas. The relation between increased nest success and higher rock cover may be explained by camouflage from visual predators or use of areas closer to ridgelines that tend to be less frequented by olfactory predators. The availability of concealing vegetation at microhabitat scales is important for GRSG conservation and should be considered in GRSG conservation strategies.

Topics: behavior or demographics, effect distances or spatial scale, habitat selection, site-scale habitat characteristics 


\section{*2019 Update* Di Stefano, S., Karl, J.W., McCord, S.E., Stauffer, N.G., Makela, P.D., and Manning, M., 2018, Comparison of 2 vegetation height methods for assessing greater sage-grouse seasonal habitat: Wildlife Society Bulletin, v. 42, no. 2, p. 213-224.}

DOI: https://doi.org/10.1002/wsb.877

Background: The majority of remaining GRSG habitat lies on public lands, and federal land management agencies have committed to monitoring its condition over time. Vegetation height is an important indicator of GRSG habitat quality. Federal agencies currently use two different methods for quantifying vegetation height, and there is confusion over which should be used and whether they produce different results.

Objectives: The authors sought to 1) quantify differences in vegetation height measured using the BLM Assessment, Inventory, and Monitoring method versus the method described in the 2015 Sage-grouse Habitat Assessment Framework, and 2) determine how often such differences result in different GRSG habitat quality assessment outcomes.

Methods: Vegetation was measured using both methods at four field sites in 2015 and 2016. The methods differ in how a sampling site is defined, selection of points for measuring vegetation height within the site, and where on the plant height is measured. The authors also simulated two plant populations with known parameters to compare results from the two methods: a dense population of smaller (herbaceous) plants and a sparse population of larger plants (shrubs).

Location: Idaho, New Mexico, South Dakota; MZ I, MZ IV

Findings: In simulations, the Habitat Assessment Framework approach produced taller mean plot vegetation heights, particularly for shrubs. In the field, the Habitat Assessment Framework method tended to include many more measurements of forb height. Additionally, correspondence between point measurements of shrubs for the two methods tended to be poor, but at the plotlevel, correspondence between the methods was stronger, and Habitat Assessment Framework heights tended to be taller, especially for shrubs. In most cases, methodological differences in vegetation height at the plot level did not change the GRSG habitat quality assessment determination for vegetation height.

Implications: The widely used BLM Assessment, Inventory, and Monitoring method tends to underestimate vegetation heights at the plot level compared to the Habitat Assessment Framework method, but these differences do not usually affect determination of the vegetation height indicator for GRSG habitat quality. The authors recommend modifying the Assessment, Inventory, and Monitoring method to increase measurement frequency and collect both perennial grass and perennial forb measurements, improving consistency between the two methods.

Topics: broad-scale habitat characteristics, site-scale habitat characteristics 


\section{Doherty, K.E., Evans, J.S., Coates, P.S., Juliusson, L.M., and Fedy, B.C., 2016, Importance of regional variation in conservation planning-A rangewide example of the greater sage- grouse: Ecosphere, v. 7, no. 10, article e01462, 27 p.}

DOI: https://doi.org/10.1002/ecs2.1462

Background: Landscape-scale models of species habitat selection and disturbance thresholds can vary across large areas. These models can best guide conservation actions when both regional variation and drivers of regional variation are understood.

Objectives: Study objectives were (1) to develop range-wide habitat and population models for GRSG that identify regional variation in habitat selection and GRSG density and (2) to assess variability in habitat selection and anthropogenic disturbance thresholds.

Methods: The authors used a suite of land-cover, landform, climate, and disturbance characteristics within 6.4 kilometers of occupied leks to model breeding habitat and predict lek occurrence for each Greater sage-grouse Management Zone (MZ). They used lek locations to model breeding location selection and its variability. They also summarized relative density of GRSG to create population indices to map high-abundance population centers.

\section{Location: range-wide; MZ I, MZ II, MZ III, MZ IV, MZ V, MZ VI, MZ VII}

Findings: Approximately one quarter of the currently occupied range is predicted to be breeding habitat, half of the breeding population of GRSG is within about 10 percent of the GRSG range, and 80 percent of GRSG populations are found within 25-34 percent of the occupied range in each MZ. Identified clusters of GRSG within each MZ made it possible to develop a relative ranking of the importance of management areas to GRSG that is available for management decisions. GRSG selection for sagebrush and avoidance of conifer cover and anthropogenic disturbance were mapped and shown to vary by MZ. GRSG in fragmented areas had a lower tolerance of anthropogenic disturbance.

Implications: Improved spatial population models show overlap of habitats, populations, conservation actions, and threats. Threats to, or conservation actions in, these hotspots could affect a large proportion of GRSG populations. Thresholds in vegetation cover types, disturbance, and other factors varied spatially, so results from one location may not extrapolate to other locations. GRSG in MZ VI (Columbia Basin) and MZ I (Northern Great Plains) appeared to diverge in functional habitat selection from other MZs. The authors emphasize the large spatial scale of this analysis and that on-the-ground management actions may need to be informed by analyses at smaller spatial scales.

Topics: agricultural conversion, broad-scale habitat characteristics, effect distances or spatial scale, energy development, fire or fuel breaks, infrastructure (roads, pipelines, powerlines, cell towers), new geospatial data, weather and climate 


\section{*2019 Update* Donnelly, J.P., Allred, B.W., Perret, D., Silverman, N.L., Tack, J.D., Dreitz, V.J., Maestas, J.D., and Naugle, D.E., 2018, Seasonal drought in North America's sagebrush biome structures dynamic mesic resources for Sage-grouse: Ecology and Evolution, v. 8, no. 24, p. 12492-12505. \\ DOI: https://doi.org/10.1002/ece3.4614}

Background: Seasonal drought limits and drives spatial patterns of primary productivity in the sagebrush ecosystem, but its effects differ across landscapes due to heterogeneity in local and biome scale soil-water balance. Seasonal limitations on vegetation resources in late summer drive sage-grouse to seek mesic sites where productivity is higher. Mesic resource availability is threatened by increasing human pressures and climatic shifts.

Objectives: The authors sought to quantify 1) patterns of primary productivity in sagebrush ecosystems, 2) the effect on productivity of various abiotic factors including precipitation, and 3) the relationship between sagebrush productivity and sage-grouse populations.

Methods: The authors used the normalized difference vegetation index quantified for 15,180 Landsat satellite images acquired from July to September of 1984-2016 to map mesic resource availability within the sagebrush biome. Precipitation, elevation, land ownership, and abundance and spatial distribution within $10 \mathrm{~km}$ of known active sage-grouse leks were quantified for four types of mesic sites: alfalfa, rangeland, riparian, and wet meadows. Sage-grouse population size was estimated using 2015 lek surveys.

\section{Location: Range-wide: MZ I, MZ II, MZ III, MZ IV, MZ V, MZ VI, MZ VII}

Findings: Productivity patterns differed between the Great Basin, Rocky Mountains, and Great Plains, with mesic productivity being most sensitive to precipitation in the Great Plains. Precipitation explained the majority of variability in mesic resource abundance. Most BLMowned mesic rangeland sites in the Great Basin tended to occur at higher elevations and were most sensitive to drought. Density of mesic resources near sage-grouse were highest in the Rocky Mountains and lowest in the Great Basin. Distance between mesic sites was greatest in the Great Basin. Private lands provide a disproportionate percentage of wet meadows, however a majority of important riparian and mesic rangeland sites occurred on public lands in the Great Basin and Rocky Mountain regions

Implications: GRSG numbers were lowest in the Great Plains and Great Basin, where mesic resources occurred at lower densities and were most sensitive to drought. The authors suggest that a diversity of mesic site types may be important for long-term sustainability of sage-grouse populations, wherein drought resilient wet meadows maintain adult survivorship in dry years and increased riparian and mesic rangeland abundance support recruitment during wet years. The strong relationship between precipitation and mesic resource availability is concerning given predicted increases in drought intensity. The authors support incentive-based programs for conserving mesic resources on private lands and provide study datasets to help prioritize conservation actions.

Topics: new geospatial data 


\section{Donnelly, J.P., Naugle, D.E., Hagen, C.A., and Maestas, J.D., 2016, Public lands and private waters-Scarce mesic resources structure land tenure and sage-grouse distributions: Ecosphere, v. 7, no. 1, article e01208, 15 p.}

DOI: https://doi.org/10.1002/ecs2.1208

Background: Water scarcity in semiarid sagebrush systems can structure important mesic food resources known to influence GRSG during the late brooding period (mid-July through September). The extent to which patterns of mesic resources over time and space influence GRSG abundance and distribution is largely unknown; such information is needed to further inform GRSG conservation efforts.

Objectives: The authors sought (1) to model long-term patterns of mesic resources over space and time, (2) to evaluate the role of mesic resources in structuring the distribution and abundance of GRSG within broad landscapes, and (3) to quantify type and land ownership of mesic resources.

Methods: Lek locations and lek surveys from 1984 to 2011 were used to model GRSG abundance and distribution across the landscape. The extent and availability of mesic areas over the same time period were modeled using a remotely sensed vegetation productivity index from late-summer satellite imagery. Relations between lek locations, mesic resource locations, and GRSG population abundance were modeled. Land ownership and type of available mesic resources and precipitation were summarized annually.

Location: Oregon, California, northwestern Nevada; MZ III, MZ IV, MZ V

Findings: Although they occupy a small percentage of the landscape, mesic areas strongly influenced the distribution of GRSG populations. Lek locations were clustered within 3-10 kilometers of mesic resources. GRSG population abundance was higher in areas closer to mesic resources. Most mesic resources are wet meadows, riparian areas, or alfalfa, and 75 percent of mesic resources are privately owned. Mesic resource abundance and lek proximity remained relatively stable during the period in comparison to more dynamic climatic patterns. Persistence of mesic sites was influenced by prolonged drought periods that reduced lek proximity in the second or third year of below average precipitation.

Implications: Protection and restoration of scarce mesic resources can preserve biodiversity, food production, and rural lifestyles. Preventing loss of mesic areas through easements, removing encroaching conifers, and restoring degraded wetlands can boost mesic resources and benefit GRSG populations. Mesic resource map products are provided that can inform such actions.

Topics: agricultural conversion, behavior or demographics, broad-scale habitat characteristics, effect distances or spatial scale, habitat selection, new geospatial data, weather and climate 


\section{Donnelly, J.P., Tack, J.D., Doherty, K.E., Naugle, D.E., Allred, B.W., and Dreitz, V.J., 2017, Extending conifer removal and landscape protection strategies from sage-grouse to songbirds, a range-wide assessment: Rangeland Ecology and Management, v. 70, p. 95- 105.}

DOI: https://doi.org/10.1016/j.rama.2016.10.009

Background: The substantial investments in GRSG conservation have resulted in ecosystem benefits believed to influence other sagebrush-obligate species such as passerine songbirds. There is little evidence, however, that demonstrates potential multispecies effects of GRSGrelated management actions.

Objectives: The authors sought (1) to identify spatial patterns of overlap between GRSG and sagebrush-obligate songbirds (Brewer's sparrow, sagebrush sparrow, and sage thrasher) and (2) to identify community-level benefits of GRSG conservation efforts such as invasive conifer removal and landscape protection.

Methods: The authors used 10 years of breeding bird surveys to model the relative abundance of sagebrush-obligate songbirds during the breeding season and 10 years of lek survey and location data to model the distribution of GRSG. They then quantified associations between songbird abundance and GRSG distribution. Finally, they evaluated associations between songbird abundance, conifer removal conducted to restore GRSG habitat, and land protected to benefit GRSG through Wyoming's Sage-Grouse Core Area Strategy and the Sage-Grouse Fire and Invasives Assessment Tool (FIAT) priority areas.

Location: range-wide; MZ I, MZ II, MZ III, MZ IV, MZ V, MZ VI, MZ VII

Findings: Songbird abundances were positively associated with GRSG distributions range-wide. Landscapes supporting higher density GRSG populations also supported higher densities of songbirds, with variability apparent by songbird species and by management zone. Restoration and land protection actions targeting GRSG also aligned with areas of higher songbird abundance.

Implications: GRSG distributions predict songbird abundance in sagebrush ecosystems, and both are affected by similar threats, particularly anthropogenic disturbance such as energy development in the eastern range and conifer encroachment and cheatgrass/wildfire in the Great Basin. Results illustrate that spatially targeted actions implemented for GRSG largely overlap high-abundance centers for three sagebrush-obligate songbirds and are likely providing significant benefit to multiple species. Spatial map products generated here can be used to identify places where management action may have community-level benefits.

Topics: behavior or demographics, broad-scale habitat characteristics, conifer expansion, habitat restoration or reclamation, new geospatial data 


\section{*2019 Update* Dudko, J.E., Coates, P.S., and Delehanty, D.J., 2019, Movements of female sage grouse Centrocercus urophasianus during incubation recess: IBIS, v. 161, no. 1, p. 222-229.}

DOI: https://doi.org/10.1111/ibi.12670

Background: Nesting is the most important life history stage of GRSG in terms of explaining annual GRSG population fluctuations. During nesting, incubating GRSG leave the nest several times daily, primarily at dusk and dawn. These departures are called incubation recesses. Little is known about the behavior of GRSG during incubation recesses.

Objectives: The authors sought to identify the area, rate, and mode of movement of female GRSG during incubation recesses, hypothesizing that movements during recess likely extend beyond the immediate nest area.

Methods: The authors collected GPS data on incubation recess movements at dawn and dusk during the nesting season from 1 and 8 female GRSG in 2014 and 2015, respectively. The authors categorized movements as walking, mixed movement, or flight; quantified movement rates and core recess areas; and monitored nest success.

Location: Nevada; MZ III, MZ IV, MZ V

Findings: The timing and duration of measured incubation recesses from GPS marked birds were consistent with previous studies. Core recess areas averaged 2.58 hectares, and females tended to use the same recess area across days. The majority of recess movements were categorized as walking while GRSG were in high-use recess areas, though GRSG primarily used flight to depart from and return to the nest. The average and longest distance moved from nests during a recess were $242 \mathrm{~m}$ and $1117 \mathrm{~m}$, respectively.

Implications: Data suggest that a larger area around nests than previously thought may be important for nesting success, which is an important consideration in determining minimum patch sizes needed for nesting and appropriate spatial scales for evaluating nesting habitat. The flights associated with recesses may expose GRSG nests to predation by common ravens. Striking vertical structures during these flights, which typically occur during low light conditions, may be a mortality risk.

Topics: behavior or demographics, effect distances or spatial scale, predators or predator control, site-scale habitat characteristics 


\section{Dumroese, R.K., Luna, T., Kilkenny, F.F., Runyon, J.B., and Richardson, B.A., 2015, Conserving and restoring habitat for greater sage-grouse and other sagebrush-obligate wildlife-The crucial link of forbs and sagebrush diversity: Native Plants, v. 16, no. 3, p. 276-299.}

DOI: https://doi.org/10.3368/npj.16.3.276

Background: Plant diversity is an important foundation for diversity in the sagebrush ecosystem and affects GRSG habitat conditions. GRSG depend on a diverse flora and invertebrate fauna for foraging, especially during spring and summer.

Objectives: This paper provided a focused discussion for nursery managers, seed producers, and land managers on (1) use of proper sagebrush seed sources for restoration, (2) development and planting of important forbs, and (3) control of invasive plants to improve restoration success.

Methods: The authors reviewed GRSG literature to describe the composition of habitat and diet important for the species. From this foundation, they described important biogeographic and species-specific aspects of flora composition relevant to habitat restoration efforts, addressing sagebrush, grasses, and forbs.

Location: The geographic range of the literature search is unclear, but it is likely broad.

Findings: A mosaic of sagebrush, grass, and forb species creates the habitat diversity and resources needed by GRSG. In addition to sagebrush, a diverse flora is important for GRSG diets. However, restoration plans and seed options generally do not well represent this diversity. The authors recognized species used by GRSG and described opportunities and current limitations for including these species in restoration. Despite considerable knowledge, practical limitations and limited planning perspectives currently limit the use of forbs in seed mixes. Invasive plants present an important challenge for restoration of flora diversity, but herbicides used to control invasive plants often have detrimental effects on desirable, native species.

Implications: Habitat conservation and restoration activities should recognize plant diversity. Research on biogeography and adaptations and cultivation of native forbs is needed to inform restoration actions and to support commercial production of the diversity of plants needed to maintain and restore sagebrush communities.

Topics: habitat restoration or reclamation, nonnative invasive plants, site-scale habitat characteristics 


\section{Dumroese, R.K., Luna, T., Pinto, J.R., and Landis, T.D., 2016, Forbs-Foundation for restoration of monarch butterflies, other pollinators, and greater sage-grouse in the western United States: Natural Areas Journal, v. 36, no. 4, p. 499-511.}

DOI: https://www.fs.fed.us/rm/pubs_journals/2016/rmrs_2016_dumroese_k004.pdf

Background: Population declines of monarch butterflies, pollinators, and GRSG are the focus of restoration and conservation efforts across the western United States. Employing holistic approaches to such efforts that focus on multiple species simultaneously may be efficient, effective, and longer lasting than single-species approaches.

Objectives: The authors sought to demonstrate how management efforts aimed at increasing native forbs on federally managed lands could leverage resources, resulting in successful conservation and restoration of monarchs, pollinators, and GRSG.

Methods: The authors describe how native forbs of the sagebrush biome support monarch nectar requirements, activities of a diverse array of pollinators, and the vegetation and invertebrates consumed by GRSG chicks and nesting and brooding hens. They reviewed restoration species lists for plants useful to monarchs, pollinators, and GRSG and created a database of plant species information to inform restoration activities. Forb planting and seeding tactics are also reviewed.

Location: northeastern California, Colorado, Idaho, Nevada, Oregon, Utah, Washington, Wyoming; MZ II, MZ III, MZ IV, MZ V, MZ VI

Findings: Significant overlap exists between the forb species needed by monarchs, pollinators, and GRSG. For many of these forb species, direct seeding over large areas may be inexpensive. Achieving sufficient forb diversity, however, may require combining direct seeding with outplanting of nursery-produced seedlings in vegetation islands.

Implications: Limited restoration resources can be linked and leveraged to meet Federal directives regarding monarch butterfly preservation, pollinator population health, and GRSG conservation by selecting native forb species for restoration of degraded landscapes in the western United States.

Topics: habitat restoration or reclamation, site-scale habitat characteristics 


\section{Duvall, A.L., Metcalf, A.L., and Coates, P.S., 2017, Conserving the greater sage-grouse-A social-ecological systems case study from the California-Nevada region: Rangeland Ecology and Management, v. 70, no. 1, p. 129-140.}

DOI: https://doi.org/10.1016/j.rama.2016.08.001

Background: Socioecological systems approaches to conservation of at-risk species bring diverse stakeholders together to develop cooperative conservation strategies that address the tradeoffs and interrelations between humans and species interests to maintain resilient ecosystems. Such approaches may be useful for addressing criticisms that the Endangered Species Act of 1973 wrongly focuses on individual species rather than ecosystem-wide function, threats, and resiliency and that it features top-down regulations rather than bottom-up voluntary actions for conservation.

Objectives: The authors presented a case study of how socioecological systems approaches were employed to plan conservation of the Bi-State Distinct Population Segment of GRSG.

Methods: Authors described the background of the Bi-State GRSG issue, the experience of stakeholders as obtained through interviews of key players in the process, the utility of the case study to inform socioecological systems approaches, and management implications of linking social and ecological aspects of rangeland conservation.

Location: California, Nevada; MZ III

Findings: Stakeholders' initial goal of preventing listing through the Endangered Species Act later shifted to one of conservation and restoration of the sagebrush ecosystem. Social engagement that employed local knowledge, the best available science, and management resources resulted in shared production of ecological conservation and monitoring plans. Several key components of the socioecological systems approach were inadvertently used, resulting in inclusivity, shared views, coproduced knowledge, and empowerment by stakeholders to enact change.

Implications: Socioecological systems approaches can be used to address complex conservation questions like endangered species management. Early employment of a systemwide view, inclusive engagement of stakeholders at multiple scales, and bottom-up empowerment can lead to success.

Topics: conifer expansion, human dimensions or economics 


\section{Duvuvuei, O.V., Gruber-Hadden, N.W., Messmer, T.A., Guttery, M.R., and Maxfield, B.D., 2017, Contribution of translocated greater sage-grouse to population vital rates: Journal of Wildlife Management, v. 81, no. 6, p. 1033-1041.}

DOI: https://doi.org/10.1002/jwmg.21264

Background: Translocating GRSG to restore or increase populations has shown low success rates compared to other game species, as measured by male lek counts. Recent demographic studies have shown that female and chick survival are important for GRSG population growth, so female translocations may lead to greater translocation success.

Objectives: The authors monitored translocated and resident juvenile and adult female GRSG from 2009 to 2013 to compare (1) their survival rates and reproductive potential and (2) the relative contribution of each to the population.

Methods: Sixty female GRSG were captured, aged, sexed, fitted with tracking collars, and translocated from the Parker Mountain source population to the Anthro Mountain translocation area. The authors monitored mortality of all translocated birds, 32 resident females, and 85 nests to determine female nesting status, nest and brood fates, and chick numbers and survival.

Location: Utah; MZ III

Findings: Survival of radio-marked females was low, and the top model indicated no significant effect of residency status. Translocated females had lower nest initiation rates during the year of release, but rates improved if they survived into the next year. Nest and brood success overall were low but similar between residents and translocated GRSG. If translocated females survive into their second year after release, their reproductive success equals that of resident females.

Implications: Translocating adult females may maximize translocation success overall, as adults are more likely than juveniles to raise a brood in the first year. Authors recommend continuing monitoring for multiple years following translocations. They suggest that factors causing declines in the focal GRSG population be mitigated prior to receiving translocated females. Otherwise, overall declines may continue despite contributions from translocations.

Topics: behavior or demographics, survival, translocation 


\section{Dzialak, M.R., Olson, C.V., Webb, S.L., Harju, S.M., and Winstead, J.B., 2015, Incorporating within- and between-patch resource selection in identification of critical habitat for brood- rearing greater sage-grouse: Ecological Processes, v. 4, article 5, 15 p.}

DOI: https://doi.org/10.1186/s13717-015-0032-2

Background: An understanding of resources needed to support critical life history stages, such as brood rearing, is needed to effectively manage landscapes, especially landscapes in which wildlife conservation is one of multiple resource objectives. GRSG require food, water, cover, and favorable thermal conditions during brood rearing, but specific needs may vary based on behavior (for example, traveling versus foraging).

Objectives: This research sought (1) to describe conditions associated with within-patch movement locations (for example, encampment, foraging, or resting) as compared to betweenpatch movement locations (for example, traveling or migration) and (2) to compare these results to the site selection identified with all location data combined.

Methods: The authors used GPS location data (19,557 locations) from 28 female GRSG collected from 2008 to 2011 to estimate brood habitat selection based on hourly movement patterns. Habitat selection models included anthropogenic, vegetation, and topographic variables. Results were compared for three behavior modes: within-patch (encamped), between-patch (traveling), and combined.

Location: Wyoming; MZ II

Findings: During within-patch movements, GRSG broods selected for taller shrubs and proximity to mesic areas and against bare ground. When traveling between patches, GRSG selected for proximity to mesic habitats and less litter cover. Habitat selection patterns for the combined behavior category were similar to those for the within-patch movement category. All six observed mortalities were associated with within-patch movements.

Implications: During brood rearing, GRSG habitat use varied depending on behavior modes: sagebrush cover was important during foraging, but more open habitats were used for movement. Proximity to mesic habitats was important for both behavioral modes. The authors suggest that effects of anthropogenic infrastructure and terrain on site selection likely exist, but they were not detected in this analysis.

Topics: agricultural conversion, behavior or demographics, broad-scale habitat characteristics, energy development, ex-urban development, habitat selection, infrastructure (roads, pipelines, powerlines, cell towers), site-scale habitat characteristics 
*2019 Update* Ebenhoch, K., Thornton, D., Shipley, L., Manning, J.A., and White K., 2019, Effects of post-release movements on survival of translocated sage-grouse: The Journal of Wildlife Management, v. 83, no. 6, p. 1314-1326.

DOI: https://doi.org/10.1002/jwmg.21720

Background: GRSG translocation has been attempted many times, with limited success. Understanding translocation success requires monitoring factors that may affect the survival and reproductive rates of translocated individuals. Post-release movement rates and distances of translocated GRSG may be higher than those of resident birds because they are unfamiliar with the landscape and have not yet integrated with the resident population.

Objectives: Study objectives were to quantify relationships between movement, survival, and productivity of newly translocated - less than one-year post translocation, previously translocated - greater than one-year post translocation, and resident GRSG.

Methods: The authors used telemetry data collected from 395 GRSG between 1989 and 2017 to quantify GRSG movements - daily distance moved, home range, and distance moved between seasonal centers, survival, and productivity (nest initiation rates and dates, distance from nest to nearest active lek, and nest success).

Location: Washington; MZ VI

Findings: Newly translocated GRSG had smaller home ranges and traveled longer daily distances than either resident or previously translocated birds, but distances moved between seasonal centers did not differ among the three groups. Annual survival was not significantly lower in newly translocated birds. Males and birds that moved greater daily distances had greater mortality risk. Newly-translocated birds initiated nests less often than other groups, but nest initiation date and nest survival did not vary with residency status. Nest success was higher when nests were initiated later in the nesting season. Resident GRSG nested farther from active leks than translocated birds.

Implications: Translocated birds that survived into a second year tended to have shorter daily movements, indicating a relationship between movements and survival that suggests translocated birds had become familiar with their landscape and no longer needed to make long distance exploratory movements. The authors suggest soft-release practices and spring release of translocated birds may help facilitate movement patterns more similar to those of resident birds, and that decreasing stress of translocated birds could facilitate nest initiation in the first year. The GRSG population at the Yakima Training Center continues to decline despite these translocations.

Topics: behavior or demographics, survival, translocation, weather and climate 


\section{Edmunds, D.R., Aldridge, C.L., O'Donnell, M.S., and Monroe, A.P., 2017, Greater sage-grouse population trends across Wyoming: Journal of Wildlife Management, $16 \mathrm{p}$.}

DOI: https://doi.org/10.1002/jwmg.21386

Background: Modeling populations of wide-ranging species at multiple spatial scales is necessary to understand trends and prioritize conservation. Understanding the downward trends in Wyoming's GRSG populations and the influence of Wyoming's Core Area Strategy on them may require multiscale model comparisons.

Objectives: Study objectives were (1) to assess lek-inferred population trends in Wyoming to determine population growth rates within multiple management delineations (Core and non-Core Areas) and (2) to determine the influence of fine-scale population trends on large-scale trends.

Methods: Lek counts from 1993 to 2015 were averaged by year and delineated by multiple management scales (such as Core Areas or Wyoming Game and Fish Department Working Group Areas). Population growth rates were modeled at different spatial scales, for varying time periods, and with known population cycles using population viability analyses.

Location: Wyoming; MZ I, MZ II

Findings: Population trends varied by magnitude and direction with the different management delineations. At small scales, neighboring populations could show different trends because of small-scale influences, indicating that large-scale trends may not capture important local phenomena. Larger populations with more years of data were more likely to show influences of population cycles and broad-scale factors like climate. Annual population decline varied by area within the state. Population growth was similar within and outside of Core Areas for most areas."

Implications: Monitoring populations at different spatial scales will allow managers to focus efforts on small-scale populations that are influencing large-scale trends, allowing for more efficient use of resources and for testing of management effectiveness.

Topics: broad-scale habitat characteristics, energy development, new geospatial data, population estimates or targets

*An issue has recently been identified with this publication that the authors are currently addressing. It is not known at this time to what extent resolution of the issue will affect the contents of this summary. 


\section{Ellsworth, L.M., Wrobleski, D.W., Kauffman, J.B., and Reis, S.A., 2016, Ecosystem resilience is evident 17 years after fire in Wyoming big sagebrush ecosystems: Ecosphere, v. 7, no. 12, article e01618, $12 \mathrm{p}$.}

DOI: https://doi.org/10.1002/ecs2.1618

Background: Understanding natural ecosystem dynamics is important for GRSG habitat management, and limited information exists on how xeric systems that are in good condition (in other words, systems with a robust understory of native grasses and forbs and few invasive grasses) recover from fire.

Objectives: The study objective was to assess vegetation composition in Wyoming big sagebrush ecosystems before and after prescribed fire.

Methods: In this experimental study, vegetation was sampled during the active growing season in burn and control plots before, 1 year after, and 17 years after a well-documented prescribed fire in the Hart Mountain National Antelope Refuge. Vegetation measurements included percent cover of shrubs, herbaceous species, litter, and bare ground; height class of shrubs; and distance to nearest mature sagebrush.

\section{Location: Oregon; MZ V}

Findings: The mosaic of fire produced variable responses in vegetation. Cheatgrass was not significantly different between burned and unburned treatments, though cover was highly variable among plots. Annual forbs responded positively to fire after 1 year, but there was no difference in cover among treatments after 17 years. Perennial forb cover varied over time and was higher in control plots than in burned plots before and after fire. Cover of forbs that are important food for GRSG varied by year but not treatment. Perennial bunchgrass cover was higher in burned plots than in unburned plots 17 years after fire. Sagebrush cover was reduced in burned plots both 1 and 17 years after fire, but sagebrush recruitment was observed.

Implications: Results demonstrate post-fire resilience of the xeric Wyoming big sagebrush system studied here, possibly because of this system's initial good condition, lack of domestic grazing, presence of unburned patches within the fire perimeter, and long time period of the study. There was a suggestion of increased annual grass cover in burned plots, and repeated fires might exacerbate this effect. Increased dominance of perennial herbaceous understory species is expected over time. Controlled burning of some xeric sagebrush systems that are in good condition and dominated by natives may have benefits for ecosystem heterogeneity and herbaceous cover.

Topics: fire or fuel breaks, nonnative invasive plants, site-scale habitat characteristics 


\section{Farzan, S., Young, D.J.N., Dedrick, A.G., Hamilton, M., Porse, E.C., Coates, P.S., and Sampson, G., 2015, Western juniper management-Assessing strategies for improving greater sage-grouse habitat and rangeland productivity: Environmental Management, v. 56, no. 3, p. 675-683. \\ DOI: https://doi.org/10.1007/s00267-015-0521-1}

Background: Juniper expansion into sagebrush habitats has negatively affected wildlife habitats and agriculture. Significant investments in juniper removal have been made on public and private land, but their effectiveness has not been evaluated.

Objectives: Study objectives were (1) to model the effectiveness of juniper management strategies for optimizing GRSG habitat restoration and cattle forage and (2) to explore how land managers could prioritize locations for suitability for both objectives.

Methods: The authors modeled the costs and benefits of juniper removal treatments stemming from optimized site selection decisions. Using sites with known changes in forage following juniper removal, they plotted a range of site biophysical attributes to describe the relation between forage increase and juniper treatments for sites across the region. They evaluated the effects of juniper treatments on GRSG lek attendance. By interviewing stakeholders, they modeled how treatment decisions were made and the costs associated with those treatments.

Location: California, Nevada, Oregon; MZ V

Findings: The study showed that juniper removal can benefit both GRSG and cattle forage production, but the benefits depend on site characteristics and how sites were selected. Sites chosen to maximize forage did not substantially benefit GRSG. Sites chosen for GRSG habitat did benefit forage production, but larger habitat treatments had decreasing returns on investment. The benefits achieved for either goal were altered by agency coordination, budgetary constraints, and wildfire.

Implications: Coordination among management agencies increases benefits for both cattle and GRSG. Using wildfire to remove juniper may not benefit GRSG as much as it would forage. Although removal program budgets are large, targets might not be met if prioritization between the two goals fails to optimize benefits.

Topics: conifer expansion, habitat restoration or reclamation, herbivory/grazing, human dimensions or economics, new geospatial data, site-scale habitat characteristics 


\section{Fedy, B.C., Kirol, C.P., Sutphin, A.L., and Maechtle, T.L., 2015, The influence of mitigation on sage-grouse habitat selection within an energy development field: PLoS ONE, v. 10, no. 4, article e0121603, $19 \mathrm{p}$.}

DOI: https://doi.org/10.1371/journal.pone.0121603

Background: Onsite mitigation of energy development effects on wildlife may increase wildlife habitat availability and quality. GRSG and energy developments in Wyoming are ideal for assessing the efficacy of onsite mitigation because of the wealth of available data and the implementation of mitigation actions over multiple spatial and temporal scales.

Objectives: The authors assessed whether the cumulative effects of multiple mitigation efforts on energy development sites (including reduced road and well-pad construction, surface disturbance, traffic, noise, and open-water reservoirs) measurably improved GRSG nesting habitat after implementation.

Methods: In the Powder River Basin of Wyoming, observations of telemetered female GRSG nesting status were made at multiple leks 4 years prior to and 4 years following mitigation. Sagebrush and conifer cover, terrain roughness, soil moisture, well density, and roads were mapped and quantified at two spatial scales ( 0.35 and 1 square kilometer $\left.\left[\mathrm{km}^{2}\right]\right)$ around 488 nests and additional random sites within available habitat. Mitigation status of each well was documented and mapped. GRSG habitat selection, available nest sites, and development characteristics were modeled to assess the effect of mitigation on GRSG use of the landscape.

\section{Location: Wyoming; MZ I}

Findings: GRSG avoided wells less after mitigation was implemented compared to before mitigation, but most GRSG nests were still located where well density was less than $1 \mathrm{well} / \mathrm{km}^{2}$, and no nests were located in areas where well density exceeded 4 wells $/ \mathrm{km}^{2}$. GRSG showed stronger selection for sagebrush cover and less avoidance of rugged terrain after mitigation. GRSG habitat ranks improved more in areas near mitigated wells compared to nonmitigated wells between the pre- and post-mitigation time periods.

Implications: Mitigation efforts appeared to improve GRSG nesting habitat, but additional studies linking habitat changes to actual species fitness are needed to determine ultimate consequences of mitigation for GRSG populations. Lower GRSG densities after mitigation may explain the stronger observed selection for sagebrush in that time period, as GRSG may have had to locate nests in suboptimal locations before mitigation.

Topics: effect distances or spatial scale, energy development, habitat restoration or reclamation, habitat selection, infrastructure (roads, pipelines, powerlines, cell towers), new geospatial data, site-scale habitat characteristics 


\section{Fedy, B.C., O'Donnell, M.S., and Bowen, Z.H., 2015, Large-scale control site selection for population monitoring-An example assessing sage-grouse trends: Wildlife Society Bulletin, v. 39, no. 4, p. 700-712.}

DOI: https://doi.org/10.1002/wsb.601

Background: Documenting the effect of human disturbance such as energy development on GRSG populations requires monitoring of both affected and unaffected control populations. For GRSG studies, finding control sites that are as similar as possible to, yet distant from, developed areas is challenging, particularly in Wyoming where energy development is prevalent.

Objectives: Study objectives were (1) to develop an approach for control site selection that uses geographic information system (GIS) data, (2) to model the differences between control and treatment sites, and (3) to verify the approach for population monitoring in other areas.

Methods: Individual leks were assessed and mapped for factors such as climate, habitat ruggedness, vegetation, roads, current and foreseeable energy development, and lek separation. Control lek sites were selected based on development, habitat similarities, data availability, and nesting habitat resource selection within a 5-kilometer buffer around the lek. Male lek attendance trends (1995-2012) were compared between the selected control sites and affected sites in the Atlantic Rim Project Area, which is being developed for natural gas extraction from coal beds.

\section{Location: Wyoming; MZ II}

Findings: The authors demonstrated that GIS-based, large-scale control site selection can be used successfully for wildlife impact monitoring, and identified 129 control sites for the current study. Both control sites and affected sites had similar trends and change-points in the cyclic trends of GRSG populations, suggesting they were tracking statewide trends and were not fundamentally different.

Implications: Using multiple habitat characteristics in the control site selection process greatly limited candidate sites, but integration of these characteristics into a resource selection function allowed for selection of an adequate number of control sites. No significant differences in population trends were observed between control and treatment sites, but the approach used did not consider inactive or extirpated leks or environmental or anthropogenic variables that might provide insights into mechanistic responses of GRSG to energy development. The control site selection process described here addresses common problems with wildlife impact monitoring (for example, too few control sites, identified subjectively, and located too close to the effect). It can also be used to monitor mitigation effectiveness, but mechanistic studies will be needed to interpret results.

Topics: broad-scale habitat characteristics, energy development, infrastructure (roads, pipelines, powerlines, cell towers), new geospatial data, population estimates or targets, weather and climate 


\section{Fedy, B.C., Row, J.R., and Oyler-McCance, S.J., 2017, Integration of genetic and demographic data to assess population risk in a continuously distributed species: Conservation Genetics, v. 18, no. 1, p. 89-104.}

DOI: https://doi.org/10.1007/s10592-016-0885-7

Background: Distinct GRSG populations can be delineated using genetic information to show where geographic isolation, movement barriers, or differences in habitat quality result in demographically independent groups. Identifying distant or isolated populations and incorporating demographic and population trends can guide monitoring and conservation actions.

Objectives: The authors sought (1) to define genetically distinct GRSG populations and their extinction risk based on decreasing population size, trends, and isolation; (2) to use spatially explicit predictions of population membership to assess isolation patterns and related barriers and corridors for movement; and (3) to relate size and demographic independence of population clusters to changes in leks over time.

Methods: Blood and feather samples were collected for DNA analysis from GRSG from 88 known lek locations. Genetic clusters of sample groups were identified and mapped with 18kilometer buffer distances and overlaid with lek locations. Authors used genetic data to estimate effective population size, migration rates, and isolation by distance. Lek counts were used to estimate population trends across populations.

Location: Wyoming; MZ I, MZ II

Findings: By combining genetic and demographic information, authors identified four genetic clusters in different regions of Wyoming with different population trends and lek activity. Northern clusters were demographically separated and genetically isolated from each other and from southern ones. Northern clusters are also more at risk (particularly northwestern ones), having not increased since the mid-1990s.

Implications: Management plans can be tailored to the needs of distinct clusters that have different population trajectories, particularly if threats and effects vary regionally. Wyoming clusters could be managed as three units (two northern, one southern). Future studies should address the cyclic nature of GRSG populations in trend estimation.

Topics: behavior or demographics, genetics, new geospatial data, population estimates or targets 
Fike, J.A., Oyler-McCance, S.J., Zimmerman, S.J., and Castoe, T.A., 2015, Development of 13 microsatellites for Gunnison sage-grouse (Centrocercus minimus) using next-generation shotgun sequencing and their utility in greater sage-grouse (Centrocercus urophasianus): Conservation Genetics Resources, v. 7, no. 1, p. 211-214.

DOI: https://doi.org/10.1007/s12686-014-0336-Z

Background: Gunnison sage-grouse have a restricted range and less genetic diversity than GRSG. Assessment of fine-scale genetic variation in Gunnison sage-grouse can elucidate connectivity among leks and relate it to habitat and anthropogenic stressors.

Objectives: The authors sought to identify and design primers for genetic markers specific to Gunnison sage-grouse.

Methods: The authors extracted DNA from the blood of 31 Gunnison sage-grouse and 14 GRSG and screened the DNA using the newly designed markers.

Location: Colorado (Gunnison sage-grouse), southwestern Wyoming (GRSG); MZ II

Findings: The authors identified 13 novel Gunnison sage-grouse microsatellites and designed primers to amplify those microsatellites. The new microsatellites work well in both species and may be useful for genetic studies of either species.

Implications: These markers have the ability to produce fine-scale genetic data identified for use in landscape and population genetic studies of Gunnison sage-grouse as well as GRSG. Finescale genetic data may also be used to identify individuals of either species.

Topics: genetics 
Forbey, J.S., Patricelli, G.L., Delparte, D.M., Krakauer, A.H., Olsoy, P.J., Fremgen, M.R., Nobler, J.D., Spaete, L.P., Shipley, L.A., Rachlow, J.L., Dirksen, A.K., Perry, A., Richardson, B.A., and Glenn, N.F., 2017, Emerging technology to measure habitat quality and behavior of grouse-Examples from studies of greater sage-grouse: Wildlife Biology, article wlb.00238, $10 \mathrm{p}$.

DOI: https://doi.org/10.2981/wlb.00238

Background: Emerging technologies might improve our ability to measure changes in GRSG habitat quality and behavior, yet many natural resource managers and conservationists are unaware of their potential to inform wildlife management.

Objectives: Study objectives were to demonstrate (1) how new technologies in laser, spectral, and chemical detection can measure habitat quality and (2) how new biotelemetry systems and robotic animals can measure how GRSG react to their surroundings.

Methods: Authors discuss use of (1) terrestrial laser scanning, a high-resolution remote-sensing tool that generates scalable three-dimensional vegetation data showing features associated with predator avoidance and nesting; (2) spectroscopy that analyzes reflected light characteristics of specific objects like high-quality GRSG food; (3) electronic noses that detect volatile organic compounds associated with how GRSG sense their environment; (4) unmanned aerial systems that can access habitat features over large areas for data collection by numerous analytical devices; (5) advanced telemetry systems that can improve tracking for behavioral studies; and (6) biomimetic robots that can elicit behavioral responses to understand GRSG tendencies and choices.

Location: applicable range-wide; MZ I, MZ II, MZ III, MZ IV, MZ V, MZ VI, MZ VII

Findings: Collecting information needed to manage habitats across landscapes is challenging and costly, so managers use surrogate measures that only indirectly relate to habitat variables. Properly tested technologies can directly assess habitat change. Technological tools can measure management-relevant GRSG behavior and parameters like resource selection, group dynamics, and disease transmission.

Implications: Significant changes in our understanding of GRSG ecology may arise from new technologies, but they will require scientific testing, calibration, and communication between managers and scientists to overcome challenges and target data collection and use.

Topics: behavior or demographics, broad-scale habitat characteristics, habitat selection, sitescale habitat characteristics 


\section{*2019 Update* Foster, L.J., Dugger, K.M., Hagen, C.A., and Budeau, D.A., 2019, Greater sage-}

grouse vital rates after wildfire: Journal of Wildlife Management, v. 83, no. 1, p. 121-134.

DOI: https://doi.org/10.1002/jwmg.21573

Background: Because GRSG depend on sagebrush during all life stages, loss of sagebrush can affect both individuals and populations. Wildfires are a primary threat to GRSG habitat and are increasing in frequency and size. Many studies have explored the effects of wildfire on GRSG habitat; less is known about potential population-level responses of GRSG.

Objectives: The authors sought to quantify effects of wildfire on GRSG survival and nesting parameters, and identify factors related to GRSG vital rates in burned and unburned areas.

Methods: From 2013 to 2015, the authors monitored a total of 64 adult and yearling female GRSG fitted with GPS transmitters. GPS data were used to identify nesting behavior and mortality events. The authors characterized nesting habitat and monitored the success of 52 GRSG nests. They also modeled relationships between both nest survival and adult survival and multiple temporal, habitat, and individual GRSG variables.

\section{Location: Oregon; MZ IV, MZ V}

Findings: Re-nesting rates increased between the first and second year of the study, and most nests were located within the fire perimeter, in remnant sagebrush patches, and under live sagebrush shrubs. Birds nesting within versus outside of the fire perimeter tended to move greater distances between nesting attempts both within and between years. First nests had low but similar survival between the two years of the study, but survival of second nests increased significantly during the second year of the study. Due to the increase in survival of second nests, average nest survival was greater in the second year, and there was support for a positive effect of distance to riparian features and a negative effect of female age. Adult survival varied with month and an acute effect of fire where survival was significantly reduced until the end of the first post-fire growing season. Average adult survival was higher in the second biological year of the study.

Implications: GRSG continued to use areas within the wildlife perimeter, but they had lower nest and adult survival rates compared to other reported values for GRSG in the Great Basin. Apparent decreased nest site fidelity within the fire perimeter may relate to increased habitat fragmentation. Increased nest survival in the second year may relate to increased vegetation in the burned area. Findings suggest that fire suppression activities to maintain intact habitat patches may be a critical tool for managers of GRSG populations and habitat in landscapes prone to fire.

Topics: behavior or demographics, broad-scale habitat characteristics, effect distances or spatial scale, fire or fuel breaks, site-scale habitat characteristics, survival 


\section{*2019 Update* Foster, L.J., Dugger, K.M., Hagen, C.A., and Budeau, D.A., 2018, Potential effects of GPS transmitters on greater sage-grouse survival in a post-fire landscape: Wildlife Biology, v. 2018, no. 1, p. 1-5.}

DOI: https://doi.org/10.2981/wlb.00479

Background: Behavior and vital rates of GRSG and other species are generally investigated by capturing and marking individuals. Accurate estimates of both rely on the assumption that capture and marking activities do not influence these characteristics. Very high mortality rates of GRSG following attachment of tracking devices in an on-going study caused the authors to question this assumption.

Objectives: The authors sought to determine if survival of female GRSG in a recently burned landscape differed between birds fitted with rump-mounted GPS transmitters versus necklacestyle VHF transmitters.

Methods: The authors captured yearling and adult female GRSG in 2012-2014: 26 individuals were fitted with VHF transmitters, and 56 females were fitted with GPS units. Mortality events were identified using hourly (GPS) or weekly or monthly (VHF) monitoring data. The authors calculated survival rates for two different twelve-month post-fire time periods, the initial fivemonth period following marking, and the final year of the study. The authors investigated potential effects of instrument type, time since attachment, and effects of fire on monthly survival rates.

\section{Location: Oregon; MZ IV, MZ V}

Findings: The top model for monthly survival contained only the effect of fire. Survival rates post-fire were low but increased somewhat by the final year of the study. Survival estimates for GRSG with VHF transmitters were slightly but not significantly higher than for birds with GPS units for all three time periods in which data from both types of transmitters were available.

Implications: Survival rates measured in this post-fire study were much lower than observed in other studies in the Great Basin, though they did eventually increase to comparable levels after the conclusion of this study. If the slightly lower survival rates of birds with GPS versus VHF devices observed in this study are confirmed, they are of concern because of the increasing use of GPS units and the potential to negatively affect population growth rates and bias study results. Findings from this study were limited by small sample sizes.

Topics: fire or fuel breaks, survival 
Freese, M.T., Petersen, S.L., and Miller, R.F., 2016, Spatial analysis of greater sage-grouse habitat use in relation to landscape level habitat structure: Journal of Ecosystem and Ecography, v. 6, no. 3, article 1000205, 10 p.

DOI: https://doi.org/10.4172/2157-7625.1000205

Background: Habitat use by GRSG varies spatially and seasonally. Quantifying GRSG habitat use across a large area can assist resource managers in conservation and restoration planning.

Objectives: The objectives of this study were (1) to model GRSG breeding and brood-rearing seasonal habitats; (2) to project these models to the study area, creating seasonal habitat suitability maps; and (3) to assess the relative importance of predictor variables.

Methods: The authors collected radio telemetry data from 50 GRSG during the 2006-2007 breeding and brood-rearing seasons. The authors used maximum entropy (specifically, Maxent software) to model seasonal probability of GRSG occurrence using landscape-level habitat variables created from 10-meter digital elevation models.

Location: central Oregon; MZ V

Findings: GRSG used low sagebrush plant communities disproportionate to their availability and more than other vegetation types during the breeding and summer seasons. Mountain big sagebrush was also heavily used in both seasons. GRSG used higher elevations and mesic areas during the summer brood-rearing period.

Implications: The authors conclude that areas containing a mixture of low sagebrush and mountain big sagebrush are important during breeding and brood-rearing seasons; high-elevation areas near streams and other water sources are also important during summer brood rearing. Projecting these models to geospatial data revealed areas of high habitat quality that could be prioritized for conservation or restoration efforts.

Topics: broad-scale habitat characteristics, effect distances or spatial scale, habitat selection, infrastructure (roads, pipelines, powerlines, cell towers), new geospatial data, site-scale habitat characteristics 


\section{Fremgen, A.L., Hansen, C.P., Rumble, M.A., Gamo, R.S., and Millspaugh, J.J., 2016, Male greater sage-grouse detectability on leks: Journal of Wildlife Management, v. 80, no. 2, p. 266-274.}

DOI: https://doi.org/10.1002/jwmg.1001

Background: Male lek counts may not accurately reflect GRSG population size if detection of birds is affected by factors such as topography, light conditions, bird behavior, vegetation cover, lek size, or movement. Using sightability studies to estimate probability of detection can improve lek count information.

Objectives: The authors sought (1) to evaluate how individual GRSG, lek, environmental, and observer characteristics affected detection probabilities at lek counts; (2) to apply the detection probabilities to estimate male lek abundance; and (3) to describe optimal conditions for male GRSG detection on leks.

Methods: The authors collected location data from 410 male GRSG across multiple active leks over 4 years. Sightability surveys that compared results of multiple observers, count intervals, and scans for radio-tagged birds were conducted on 22 leks. Variables such as timing, sky conditions, bird activity, group size, bird location, and vegetation characteristics that could affect an observer's ability to spot birds were recorded and modeled to estimate probability of detection. Probabilities of detection were then used to correct lek count data.

Location: Wyoming; MZ II

Findings: Although detection probabilities were high, they were affected by sagebrush height and snow cover. Other factors such as bird behavior, light conditions, wind, precipitation, and topography did not affect detection. Detectability did not vary annually, across leks, or with lek size, suggesting that lek counts may be good indices of population size.

Implications: Conducting sightability surveys to establish correction factors is recommended to avoid underestimation of regional GRSG abundance, particularly if vegetation and snow cover vary among leks. The authors recommend conducting counts between 30 minutes before and 30 minutes after sunrise, waiting at least 2 days after snowfall to conduct lek counts, and considering how landscape features may affect visibility of the birds.

Topics: behavior or demographics, population estimates or targets, weather and climate 


\section{Fremgen, A.L., Rota, C.T., Hansen, C.P., Rumble, M.A., Gamo, R.S., and Millspaugh, J.J., 2017, Male greater sage-grouse movements among leks: Journal of Wildlife Management, v. 81 , no. 3 , p. $498-508$.}

DOI: https://doi.org/10.1002/jwmg.21208

Background: When male GRSG move between leks, they may be double-counted or missed when leks are counted, which can lead to errors in population estimates derived from lek data. Estimating the daily probability of movement between leks would improve lek and population data and further our understanding of GRSG ecology.

Objectives: The authors sought (1) to estimate the probability of daily movement between leks and (2) to evaluate factors such as weather and site characteristics that may influence movement patterns.

Methods: The authors collected weight, age, and GPS location data from 145 male GRSG from multiple active leks between 2011 and 2014. Boundaries of active leks; numbers of visiting birds; estimated size, age, and location of males and females at leks; survival; lek attendance by telemetered males; physical characteristics of leks; and daily environmental conditions were all included in models developed to predict daily interlek movement.

\section{Location: Wyoming; MZ II}

Findings: Despite high annual fidelity to their leks, 33 percent of males made crossings between leks at least once, and some more than 10 times, per breeding season. Most movements between leks ( 78 percent) were to the nearest or second nearest lek. Movements between leks tended to occur earlier in the spring and to leks at higher elevations. Tendencies to move between leks toward larger leks, on rainy days, and on days with no wind, as well as tendencies for adults to move more than yearlings, were apparent but not included in the top model.

Implications: The reported frequency of crossing between leks is higher than in previous estimates. As such, movements between leks may explain a substantial amount of variability in annual lek counts, reducing the ability of lek count data to accurately depict GRSG population abundance or trends. Lek counts done earlier in the spring are less likely than those done later (at peak attendance) to reflect population abundance, particularly in areas where male GRSG move to higher elevations as snowpack melts. Conducting lek counts during peak attendance and avoiding counts during days with precipitation, particularly at higher elevations, is recommended.

Topics: behavior or demographics, habitat selection, new geospatial data, population estimates or targets, weather and climate 
*2019 Update* Fremgen, A.L, Hansen, C.P., Rumble, M.A., Gamo, R.S, Millspaugh, J.J., 2019, Weather conditions and date influence male sage grouse attendance rates at leks: IBIS, v. 161 , no. 1 , p. $35-49$.

DOI: https://doi.org/10.1111/ibi.12598

Background: Lek counts are typically used to monitor population trends for GRSG, but these counts can be a problematic indicator because of variability in lek attendance by males. Understanding factors affecting lek attendance can inform lek count protocols, leading to improved estimates of GRSG population sizes and trends.

Objectives: The authors studied daily attendance rates of male GRSG at leks, the relation between lek attendance rates and lek counts, and how habitat, time, weather, and biological factors influenced attendance rates.

Methods: The authors captured 145 yearling and adult male GRSG between 2011 and 2014 and fitted them with GPS transmitters, resulting in 24-58 GRSG tracked each year. The authors monitored 58 leks and quantified precipitation, wind speed, and habitat data for each lek, including elevation, slope, aspect, and sagebrush cover in the surrounding area.

Location: Wyoming; MZ II

Findings: Daily probabilities of attendance ranged from 0.55 to 0.96 across the study years. Estimated male abundance was up to four times greater than male lek counts. In three of the four years of the study, the top model for lek attendance included variables for day of year, precipitation, and wind. Peak attendance varied by year and day of year, occurring between midApril and mid-May. Precipitation negatively affected attendance and a slight effect of wind was variable. In the remaining year, the top model included effects of day of year and GRSG age, with adult attendance being much higher than that of yearlings.

Implications: Considering potential biases of attendance and detection can improve the performance of lek counts as indices of population abundance. Attendance here was strongly influenced by precipitation, consistent with other studies and supporting lek-count protocols that discourage counts during rain. Slight negative effects of wind observed here also support avoiding counts during high winds.

Topics: behavior or demographics, broad-scale habitat characteristics, population estimates or targets, weather and climate 


\section{Fremgen, M.R., Gibson, D., Ehrlich, R.L., Krakauer, A.H., Forbey, J.S., Blomberg, E.J., Sedinger, J.S., and Patricelli, G.L., 2017, Necklace-style radio-transmitters are associated with changes in display vocalizations of male greater sage-grouse: Wildlife Biology, article wlb.00236, 8 p.}

DOI: https://doi.org/10.2981/wlb.00236

Background: Use of radio telemetry in GRSG demography and habitat-use studies is widespread, yet the effects of these tracking devices on GRSG behavior are not known. Transmitters may interfere with strut displays made by male GRSG to attract mates, given the energetic movement and esophageal activity this behavior requires.

Objectives: The study objective was to evaluate the effect of radio collars placed near esophageal air sacs of male GRSG on the acoustic properties of the vocalizations GRSG make to attract mates.

Methods: The authors recorded vocalizations of 19 adult male GRSG either with or without radio collars at five leks in Idaho and Nevada. Recordings were analyzed using spectrograms, from which the time and frequency characteristics of the different notes the birds produced were measured. Videos of male displays were analyzed for strut rate and interval.

Location: Idaho, Nevada; MZ III, MZ IV

Findings: Strut rate and most of the characteristics of male vocalizations did not differ between birds with and without collars. Collared males in both study areas had a lower maximum frequency of the primary whistle, which fell outside the typical range of males without collars. The primary whistle of collared males in Idaho was also shorter and had a narrower bandwidth than that of males without collars, and the secondary coo of these birds was shorter.

Implications: Vocalizations made by males with necklace-style radio transmitters fell outside the normal range of vocalizations produced by males throughout the range of GRSG, suggesting that radio collars may impair their ability to produce normal vocalizations. The only vocal characteristic that was altered by collars in both populations (maximum frequency of the primary whistle) is known to influence mating success from other studies, thereby potentially affecting male fitness. The use of necklace-style collars that sit on the necks of GRSG are not recommended for use in behavioral studies of GRSG. Alternative attachment methods should be developed and tested.

Topics: behavior or demographics 


\section{Gamo, R.S., and Beck, J.L., 2017, Effectiveness of Wyoming's sage-grouse core areas- Influences on energy development and male lek attendance: Environmental Management, v. 59 , no. 2 , p. $189-203$.}

DOI: https://doi.org/10.1007/s00267-016-0789-9

Background: The Wyoming Governor's 2008 Executive Order for Sage-Grouse outlines a strategy to designate Core Areas - the most productive habitats for GRSG-where anthropogenic disturbances are then limited. The effectiveness of the Core Area Strategy for conserving GRSG has not been evaluated.

Objectives: The authors sought to evaluate energy development and compare GRSG lek attendance in Core and non-Core Areas to inform assessment of the executive order's short-term effectiveness.

Methods: Looking across the entire area of GRSG habitat in Wyoming, authors counted active well pads on and off Core Areas for each year between 1986 and 2014. They measured peak male attendance at 958 active leks from 1996 through 2014. GRSG population cycles were used to assess the influence of Core Area designation. Results were analyzed by Greater sage-grouse Management Zone (MZ) and statewide. Data describing implementation of the executive order from 2012 through 2014 were also assessed.

Location: Wyoming; MZ I, MZ II

Findings: Number of well pads increased over the study period, significantly more so in nonCore Areas. Lek numbers generally show that Core Areas are more productive GRSG habitats. During periods of increasing GRSG population, counts in Core Areas increased more and were less variable than in non-Core Areas, particularly in MZ II. Surface disturbance that occurred during the period that the executive order was in place mostly occurred according to the order's stipulations.

Implications: Results provide support for the Core Area designations effectively tempering development and contributing to population stability statewide and in MZ II. Despite implementation of the 2008 Executive Order for Sage-Grouse, GRSG populations in MZ I appear vulnerable to further decline. Mitigation and changes in development rate may improve population numbers.

Topics: broad-scale habitat characteristics, energy development, habitat selection, population estimates or targets 


\section{Garman, S.L., 2017, A simulation framework for assessing physical and wildlife impacts of oil and gas development scenarios in southwestern Wyoming: Environmental Modeling and Assessment, v. 23, no. 1, p. 39-56.}

DOI: https://doi.org/10.1007/s10666-017-9559-1

Background: Energy development infrastructure such as roads, well pads, and wells results in losses of habitat and connectivity for GRSG in large portions of their range. Future energy extraction endeavors could utilize new directional-drilling techniques that are capable of drilling in multiple directions from a single pad. The conservation benefits of this technique, in terms of reductions to area affected, have not yet been quantified.

Objectives: The author's objectives were (1) to develop an energy footprint model to simulate well, well-pad, and road spatial arrangements and (2) to use the model simulations to test the amount of area affected by energy development under different extraction scenarios using vertical and directional wells.

Methods: A standalone model was built that uses geospatial data representing the landscape of interest along with user-entered energy infrastructure parameters (for example, number of wells, wells per pad, well types, and roads) to provide maps and estimates of the energy development footprint under each scenario as well as simulated effects on certain wildlife species. For the case study, the author simulated 10 directional-drilling and conventional-drilling scenarios, manipulating the number of pads and wells but holding the total amount of energy extracted over a 15-year period constant.

Location: southwestern Wyoming; MZ II

Findings: Use of directional-drilling technology resulted in fewer pads and a substantial reduction in the area disturbed by energy extraction, which benefited model-simulated GRSG lek attendance. Differences were also observed in spatial patterning of development.

Implications: Minimizing energy development effects on habitats used by GRSG and other species will become increasingly important. This simulation framework could aid resource managers and energy companies in designing development configurations that have reduced effects on habitats. Further, the directional-drilling technology examined here could provide a means of reducing energy development footprints.

Topics: behavior or demographics, energy development, infrastructure (roads, pipelines, powerlines, cell towers), new geospatial data 


\section{Gibson, D., Blomberg, E.J., Atamian, M.T., and Sedinger, J.S., 2015, Observer effects strongly influence estimates of daily nest survival probability but do not substantially increase rates of nest failure in greater sage-grouse: The Auk, v. 132, no. 2, p. 397-407.}

DOI: https://doi.org/10.1642/AUK-14-197.1

Background: Observers can affect nest survival for GRSG by flushing hens and exposing eggs to predators. As a result, survival estimates can be biased low, and survey efforts could endanger small populations.

Objectives: The authors sought (1) to quantify observer effects on nest survival and (2) to assess biases in estimates of nest survival associated with observer-related abandonment.

Methods: The authors used radio telemetry to locate and monitor 396 GRSG nests from 2005 to 2012. They visited nests twice per week to determine nest fate and estimated timing of nest initiation by floating eggs. Models of daily nest survival tested effects of observers after accounting for habitat characteristics around nests and hen age. The authors applied simulated encounter histories to abandoned sites based on survival estimates at unabandoned sites to estimate bias in survival related to observer effects. Post hoc analyses tested whether habitat characteristics differed among nest sites that were successful, abandoned, or depredated.

Location: central Nevada; MZ III

Findings: Of all nests monitored in the study, 32 percent hatched, 52 percent were depredated, and 16 percent were abandoned. Observer effects were negligible unless hens flushed during surveys. Daily nest survival was significantly reduced the day after flushing, but reductions in nest success were small when hens were flushed only once during the nesting period. When flushed from nests, young hens or hens in poor habitat were more likely to abandon their nests (and had lower nest survival) than mature hens or hens in high-quality habitat.

Implications: Observer-induced nest abandonment can decrease estimates of daily nest survival. The authors recommend assessing the potential costs and benefits of nest surveys on sensitive populations and incorporating bias corrections into estimates of nest survival.

Topics: behavior or demographics, site-scale habitat characteristics 


\section{Gibson, D., Blomberg, E.J., Atamian, M.T., and Sedinger, J.S., 2016, Nesting habitat selection influences nest and early offspring survival in greater sage-grouse: The Condor, v. 118 , no. 4 , p. $689-702$.}

DOI: https://doi.org/10.1650/CONDOR-16-62.1

Background: Assessments of habitat quality inform conservation strategies for GRSG, but they are complicated by biotic and abiotic interactions that can restrict GRSG to poor-quality habitats. Habitat quality assessments based on multiple indices of fitness should provide more reliable results than assessments based on a single index.

Objectives: Study objectives were to evaluate to what extent nesting habitat characteristics selected by GRSG where related to (1) nest survival, (2) chick survival, and (3) number of fledged young.

Methods: The authors used radio telemetry to monitor 234 GRSG hens, productivity of 411 nests, and survival of 120 broods from 2004 to 2012. They measured vegetative cover and habitat characteristics at nests at a local scale (within 5 meters [m] of nest) and landscape scales (within $500 \mathrm{~m}, 1$ kilometer [km], and $2 \mathrm{~km}$ ) and at randomly selected points without nests to develop predictors for habitat analyses. Nest site, nest survival, chick survival, and number of fledged birds were responses in resource selection functions that evaluated the importance of local- and landscape-scale habitat characteristics for GRSG.

Location: central Nevada; MZ III

Findings: The top model for nest site selection based on local-scale variables indicated a positive relation with sagebrush, shrub, and forb cover; taller forbs and grasses; and more diverse forbs and a negative relation with tall shrubs. The best landscape-scale model indicated selection for sagebrush cover, moderate elevations, slopes, proximity to water sources, and lower cover of pinyon-juniper woodlands and against areas with higher cover of pinyon-juniper woodlands.

Nest habitat selection was positively related to nest and chick survival at the local scale but not at the landscape scale. Chick survival was higher farther from leks.

Implications: Female GRSG appeared to select for nesting habitat that increased chick survival rather than nest survival. Overall selection for nesting habitat was associated with increased reproductive success at the local but not landscape scale. Variability in results among habitat characteristics, spatial scales, and reproductive response variables demonstrates the importance of assessing multiple metrics of each. Areas with leks where nest site selection aligns with reproductive success may be priorities for protection as critical habitat.

Topics: behavior or demographics, broad-scale habitat characteristics, conifer expansion, effect distances or spatial scale, habitat selection, site-scale habitat characteristics, survival 


\section{Gibson, D., Blomberg, E.J., Atamian, M.T., and Sedinger, J.S., 2017, Weather, habitat composition, and female behavior interact to modify offspring survival in greater sage- grouse: Ecological Applications, v. 27, no. 1, p. 168-181.}

DOI: https://doi.org/10.1002/eap.1427

Background: Weather can affect GRSG populations, but individuals can alter how they select habitats to mitigate stress from events such as drought. Nest site selection is crucial to GRSG fitness and can reveal their adaptive ability to respond to drought.

Objectives: The authors evaluated relations between (1) weather and brood survival, (2) drought and breeding site selection, and (3) shifts in breeding site selection and brood survival of GRSG.

Methods: The authors used radio telemetry to monitor 120 broods from 99 GRSG hens and measure habitat use from 2005 to 2012. They measured vegetation around brood locations and estimated survival of individual chicks from weekly flush counts until the brood was 42 days old. Regression models related brood survival to habitat variables important to chick survival and interannual differences in habitat selection to drought severity.

Location: central Nevada; MZ III

Findings: Chick survival was negatively related to drought severity, amount of daily brood movement, and grass height and positively related to elevation, percent cover of vegetation, distance from water source, hen age (through age 3), and female nest site selection (in other words, chick survival was higher when vegetation characteristics of the nest site were selected for by females). A number of interactions with drought were significant as well. For example, chick survival was less sensitive to drought at higher elevations, appeared to benefit more from female nest site selection during drought years, and appeared to suffer more from greater brood movement during drought. Hens nested at higher elevations and in areas with more vegetation in drought years, and broods initially moved more in drought years.

Implications: Nest sites at low elevations may contribute little to reproduction in drought years, and extended droughts may be detrimental to GRSG populations that cannot access highelevation sites. Although GRSG adjusted nest site selection to mitigate effects of drought, their adaptive capacity may be unable to accommodate drought conditions predicted to result from climate change.

Topics: behavior or demographics, habitat selection, site-scale habitat characteristics, survival, weather and climate 


\section{*2019 Update* Gibson, D., Blomberg, E.J., Atamian, M.T., Espinosa, S.P., and Sedinger, J.S., 2018, Effects of power lines on habitat use and demography of greater sage-grouse (Centrocercus urophasianus): Wildlife Monographs, v. 200, no. 1, p. 1-41.}

DOI: https://doi.org/10.1002/wmon.1034

Background: Power lines are present across much of the GRSG range and may influence GRSG directly, through mortality and habitat loss, and indirectly through avoidance, harassment by predators, and electromagnetic fields. Power lines can also provide nesting and perching sites for avian predators. Relatively few studies have quantified effects of power lines on GRSG.

Objectives: Study objectives were to quantify 1) the effect of power lines on GRSG habitat selection, demographic rates, and population dynamics using long term data from one site, and 2) the relationship between avian predator abundance and GRSG behavior and demographics.

Methods: From 2003 to 2012, the authors surveyed raptors and corvids, banded 988 male and radio-marked 261 female GRSG, and monitored 13 leks that were within $21 \mathrm{~km}$ of a transmission line. The authors quantified multiple nest, brood, habitat use, and survival metrics for females; and survival, movement, recruitment, and population growth rates for males. Distance from the transmission line (build completed in 2004), from any power line, and from roads, were the covariates of interest.

\section{Location: Nevada; MZ III}

Findings: Lek counts declined over the study period, while raven counts increased. Nesting propensity did not relate to distance from transmission line. GRSG selected nest sites near roads and avoided sites near power lines when raven abundance was high. Probability of re-nesting was higher near the transmission line to about $12.5 \mathrm{~km}$. Nest and chick survival appeared to be lower near the transmission line when raven counts were higher, with the effect extending to $12.5 \mathrm{~km}$. Brood site selection was negatively related to proximity to a power line to a distance of $7.5 \mathrm{~km}$. Female survival did not appear to be influenced by ravens. Male survival near the transmission line declined over the study, but proximity to the line did not affect male movement rates. Male population growth declined more near the transmission line and was lower when raven and raptor abundance was high. Recruitment rates declined more over the study at leks closer to the transmission line and was lower when raven abundance was high. Ravens were more likely to occur near GRSG leks located closer to the transmission line and to highways.

Implications: There was support for GRSG avoidance of power lines to $10 \mathrm{~km}$, for decreased demographic rates to $12.5 \mathrm{~km}$, and for decreased population growth to $5 \mathrm{~km}$. Multiple effects of transmission lines varied with raven abundance, which increased near the transmission line in this study. Some effects were small, highlighting the importance of long-term, 10-20 year, studies of impact assessment. Transmission line effects on GRSG may be mitigated by decreasing raven numbers near the line, but the effectiveness of previous predator control and perch deterrent efforts have been inconclusive. Co-locating, burying, or routing lines outside of GRSG habitat may be options. 
Topics: behavior or demographics, broad-scale habitat characteristics, effect distances or spatial scale, habitat selection, infrastructure (roads, pipelines, powerlines, cell towers), population estimates or targets, predators or predator control, site-scale habitat characteristics, survival 


\section{Gibson, D., Blomberg, E.J., and Sedinger, J.S., 2016, Evaluating vegetation effects on animal demographics-The role of plant phenology and sampling bias: Ecology and Evolution, v. 6, no. 11, p. 3621-3631.}

DOI: https://doi.org/10.1002/ece3.2148

Background: Many studies measure how vegetation affects GRSG nest survival, but the timing of vegetation surveys relative to nesting activity has varied in ways that may alter the statistical validity of the outcomes reported.

Objectives: The study objective was to examine how the timing of vegetation surveys in GRSG nesting studies may affect the analysis and interpretation of results.

Methods: The authors conducted a literature search through Google Scholar for publications that assessed the influence of grass height or cover on nest success; they used information from 22 grassland and shrubland bird nesting studies to compare the timing of vegetation surveys based on dates of hatching or nest-fate observations. Using scenarios in which grass height had variable effects on nest survival (that is, no effect, positive effect, and negative effect), they simulated changes in grass height and nest observation data. They used observational data from 8 years of nest and grass-height monitoring in Nevada to compare how results changed based on measurement timing.

\section{Location: Nevada; MZ III}

Findings: Published findings tended to show a positive effect of grass height on nest survival if measured at the time of nest fate, while vegetation sampled at predicted hatch date was less likely to show an effect of grass height on nest success. Simulations and observational data showed that measurements made at hatch date more accurately predicted relations between grass height and nest survival. Vegetation observations made at nest fate showed strongly biased positive relations, leading to interpretations that the positive effect of grass height on nest survival was higher than in reality. Models with this positive bias tended to be statistically stronger than models that were more biologically meaningful.

Implications: Statistical artifacts can confound interpretations of the importance of vegetation to GRSG nest survival. Researchers should consider the confounding effects of plant phenology when planning animal demography studies. The authors provide techniques for date corrections between hatching and nest-fate measurement.

Topics: behavior or demographics, site-scale habitat characteristics 


\section{Green, A.W., Aldridge, C.L., and O'Donnell, M.S., 2017, Investigating impacts of oil and gas development on greater sage-grouse: Journal of Wildlife Management, v. 81, no. 1, p. 46- 57.}

DOI: https://doi.org/10.1002/jwmg.21179

Background: Oil and natural gas developments reduce sagebrush habitat and create other disturbances including noise, human activity, and roads that can affect GRSG populations. Previous studies of GRSG responses to energy development have examined population responses over short time frames and were limited in their ability to detect population declines or failed to account for uncertainty in abundance indices over longer time frames.

Objectives: The authors sought (1) to evaluate effects of oil and gas development on lek attendance by GRSG across a large spatiotemporal extent and (2) to estimate trends in lek attendance at fine and broad spatial scales.

Methods: The authors compiled data on GRSG lek counts, well density, and the disturbance area of well pads across Wyoming for each year from 1980 to 2008. They analyzed these data, along with estimates of sagebrush cover and seasonal precipitation, at five spatial scales that ranged from 800-meter (m) to 6,400-m radii around leks and with covariates that modeled time lags in GRSG responses of 1 to 4 years. Bayesian, hierarchical, state-space models provided effect estimates for energy developments from the time series of lek counts that accounted for missing data, sagebrush cover, and precipitation.

\section{Location: Wyoming; MZ I, MZ II}

Findings: Oil and gas developments contributed to a 2.5 percent per year decline in lek attendance from 1980 to 2008. The best models indicated that GRSG responded to energy development with a 4-year time lag, and well density within $6,400 \mathrm{~m}$ of leks best explained GRSG losses. Sagebrush cover and precipitation explained little variation in lek attendance over time. Across Wyoming, declines in lek attendance were variable. Decreases in lek attendance were significant at a density of 4 wells per square kilometer, reaching 17 percent per year at 5.24 wells per square kilometer.

Implications: Study results provide further support for a negative effect of oil and gas developments on GRSG populations, and declines may become evident 1-4 years after development. Current regulations in Core Areas could limit GRSG losses from energy developments, but they may not promote GRSG recovery. GRSG declines could be more severe outside of Core Areas, and other species associated with sagebrush may show similar trends.

Topics: broad-scale habitat characteristics, effect distances or spatial scale, energy development, infrastructure (roads, pipelines, powerlines, cell towers), population estimates or targets, weather and climate 


\section{Gruber-Hadden, N.W., Messmer, T.A., Maxfield, B.D., Koons, D.N., and Guttery, M.R., 2016, Population vital rates of resident and translocated female greater sage-grouse: Journal of Wildlife Management, v. 80, no. 4, p. 753-760.}

DOI: https://doi.org/10.1002/jwmg.1062

Background: Translocations have been implemented with limited success as a recovery strategy for small or extirpated populations of GRSG. Translocation can increase numbers and genetic diversity of GRSG in small populations, but success depends on vegetation characteristics, the presence of landscape barriers to movement, preexisting populations, and timing of releases.

Objectives: The authors sought (1) to determine whether translocated GRSG remained at isolated release sites that lacked dispersal barriers and (2) to compare female and chick survival and nest and brood success between translocated and resident GRSG.

Methods: During 2009-2010, the authors collected radio telemetry data from 49 translocated and 14 resident female GRSG and from 49 and 50 chicks randomly selected from broods of the translocated and resident females, respectively. Telemetry data were used to monitor dispersal, adult survival, nest success, brood success, and chick survival. Fine-scale measures of vegetation around nest sites provided the means to account for habitat in analyses of survival and reproduction. Analyses included covariates for year, residency status, and chick age.

Location: northeastern Utah; MZ III

Findings: Retention of translocated GRSG within the targeted release site was 82 percent. There was not statistical support for a difference between resident and translocated birds for female, nest, and chick survival, but sample sizes were small. Nest initiation rates and clutch sizes were generally higher for residents compared to translocated GRSG. Nest success was positively related to grass height.

Implications: Overall, rates of survival, but not nest success, were low for resident and translocated GRSG in this study relative to rates observed in other regions. Successful translocations will depend on resolving issues that have imperiled the resident population. Habitat management that improves cover and structure of grass during the breeding season could improve success in recovery efforts.

Topics: behavior or demographics, site-scale habitat characteristics, survival, translocation 


\section{*2019 Update* Gustafson, K.B., Coates, P.S., Roth, C.L., Chenaille, M.P., Ricca, M.A., Sanchez-Chopitea, E., and Casazza, M.L., 2018, Using object-based image analysis to conduct high-resolution conifer extraction at regional spatial scales: International Journal of Applied Earth Observation and Geoinformation, v. 73, p. 148 - 155.}

DOI: https://doi.org/10.1016/j.jag.2018.06.002

Background: The expansion of pinyon-juniper conifers is a threat to the viability of sagebrush ecosystems, which support several at-risk species including GRSG. High-resolution remotesensing of pinyon-juniper distribution at regional scales is needed to create maps that inform land managers and aid in targeted sagebrush restoration.

Objectives: The authors sought to 1) create a high-resolution raster of conifer cover across the study area, 2) derive scaled estimates of conifer cover that match standard resolutions of mapping products, and 3) generate tools that target pinyon-juniper treatment priority areas to help restore GRSG habitat.

Methods: Conifer feature extraction and accuracy assessments were conducted for Nevada's 61 GRSG population management units using object-based image analysis and automated feature extraction. These results were validated by ground referencing to assess errors of omission and commission.

\section{Location: Nevada, California; MZ III, MZ IV, MZ V}

Findings: The authors present maps of conifer canopy cover that more accurately depict ground conditions than existing Landsat products. Maps produced include 1) a $1 \mathrm{~m}^{2}$ resolution binary raster of conifer canopy presence or absence, 2) a $900 \mathrm{~m}^{2}$ resolution raster showing the percent of conifer canopy, 3) a $50 \mathrm{~m}$ moving window raster of canopy cover, based on the $1 \mathrm{~m}^{2}$ binary raster, 4) a map of conifer canopy reclassified at intervals of biological significance to GRSG, and 5) a confusion matrix linked to population management units.

Implications: The maps produced can help to inform land managers on where to target pinyonjuniper treatment in order to aid in sagebrush restoration and GRSG conservation.

Topics: conifer expansion, habitat restoration or reclamation, new geospatial data, site-scale habitat characteristics 


\section{Guttery, M.R., Messmer, T.A., Brunson, M.W., Robinson, J.D., and Dahlgren, D.K., 2016, Declining populations of greater sage-grouse-Hunter motivations when numbers are low: Animal Conservation, v. 19, no. 1, p. 26-34.}

DOI: https://doi.org/10.1111/acv.12213

Background: Species rarity can increase hunter demand because of anticipated limits in hunting opportunities that may arise through regulation. Despite the candidacy of GRSG for protection under the Endangered Species Act of 1973, regulated hunting of GRSG continues in 10 states. Conservation efforts to recover populations in these states could be undermined by this sociological phenomenon.

Objectives: The authors sought to understand how hunter satisfaction and motivations vary with conservation status of GRSG.

Methods: The authors compiled surveys conducted by the Utah Division of Wildlife Resources from 2008 to 2010 to characterize motivation and satisfaction of 838 hunters who pursued GRSG. The authors related satisfaction, categorized in five levels, to explanatory variables of harvest success, hunter effort, and awareness of conservation status. Chi-square tests determined differences in frequency of categorical responses for hunter motivation.

Location: Utah; MZ II, MZ III, MZ IV

Findings: Hunter success best explained hunter satisfaction, but many hunters expressed satisfaction regardless of success. Following the 2010 listing decision, hunter demand for GRSG and interest in GRSG as a trophy increased, but statistical support was limited. Most hunters were motivated by sharing an outdoor experience with family, meat procurement, or tradition.

Implications: Hunting is a significant funding source for species conservation, so regulatory agencies are challenged to balance socioeconomic interests with management of rare species. Hunting regulations and lack of perception of GRSG as a trophy species appeared to limit increases in hunter demand that can accompany changes in conservation status.

Topics: human dimensions or economics, hunting 


\section{*2019 Update* Hagen, C.A., Sedinger, J.E., and Braun, C.E., 2018, Estimating sex-ratio, survival, and harvest susceptibility in greater sage-grouse: making the most of hunter harvests: Wildlife Biology, article wlb.00362.}

DOI: https://doi.org/10.2981/wlb.00362

Background: Realizing differences in sex- and age-specific survival rates and harvest vulnerability is critical for understanding population dynamics and setting hunting regulations in managed GRSG populations. However, little information exists on the harvest vulnerability of various GRSG demographics, and information on juvenile (hatch-year) survival and annual variation in recruitment is particularly lacking.

Objectives: The authors' objectives were to determine several population statistics for GRSG, including: 1) survival of juveniles into adulthood, 2) harvest rates of two age-classes, juvenile and adult, and 3 ) the tertiary sex-ratio.

Methods: During July and August over a six-year span from 1978 to 1983, 3,259 GRSG were captured, marked with bands, and released. After the hunting season, bands were recovered from hunters via check stations, wing barrels, questionnaires, and personal reports. Using recovered wings, annual recovery rates were estimated for both sexes of adults and juveniles.

Location: Colorado; MZ II

Findings: Major findings include: 1) juvenile GRSG were twice as vulnerable to harvest as adults, 2) no significant difference was observed between male and female vulnerability in adult harvest, 3) high annual variation in survival of juveniles with similarities between females and males, and 4) sex ratios similar to formerly assumed proportions for both adults and juveniles.

Implications: The authors suggest demographics of harvested populations can be modeled for GRSG or other game birds using a mark-recovery approach of harvested individuals.

Topics: behavior or demographics, human dimensions or economics, hunting, population estimates or targets, survival 
Hanks, E.M., Hooten, M.B., Knick, S.T., Oyler-McCance, S.J., Fike, J.A., Cross, T.B., and Schwartz, M.K., 2016, Latent spatial models and sampling design for landscape genetics: Annals of Applied Statistics, v. 10, no. 2, p. 1041-1062

DOI: https://doi.org/10.1214/16-AOAS929

Background: Conservation planning for GRSG often focuses on landscape connectivity because of its importance in maintaining biodiversity and vulnerability to anthropogenic disturbances. Landscape genetics can provide insight into population connectivity using spatially explicit habitat and genetic data. However, landscape genetics approaches are sensitive to uneven sampling.

Objectives: Study objectives were (1) to develop a model to optimize sampling for GRSG landscape genetics and (2) to demonstrate how to optimize sampling designs for investigations of genetics and connectivity.

Methods: Eight hundred and thirty GRSG feathers were collected opportunistically (while traversing the lek) at 243 leks across the southwestern half of the GRSG range from 2009 to 2012. Genetic material from the feathers provided inputs to models of genetic relatedness that used spatial correlation to account for distribution in genetic exchange. The authors then developed two design criteria to evaluate simulations of alternative sampling designs for obtaining genetic material at leks across the entire GRSG range to support analyses of landscape genetics.

Location: California, Colorado, Idaho, Montana, Nevada, North Dakota, Oregon, South Dakota, Utah, Wyoming, Washington; MZ I, MZ II, MZ III, MZ IV, MZ V, MZ VI, MZ VII

Findings: The top model of spatial lek networks assumed that leks greater than 25 kilometers apart were conditionally independent and had an edge weight inversely proportional to the squared distance between leks. Important sampling areas depended on the design criterion; the optimal categorical design predicted allele prevalence slightly better than the latent Gaussian design but was computationally intensive.

Implications: Models in this paper can be used to optimize sampling for landscape genetics following a pilot sample which may be applicable to other species with spatially distributed populations and breeding behaviors similar to GRSG. These models focus on understanding range-wide genetic diversity, but alternative designs can investigate fringe or isolated populations.

Topics: broad-scale habitat characteristics, genetics 


\section{Hansen, C.P., Schreiber, L.A., Rumble, M.A., Millspaugh, J.J., Gamo, R.S., Kehmeier, J.W., and Wojcik, N., 2016, Microsite selection and survival of greater sage-grouse nests in South-central Wyoming: Journal of Wildlife Management, v. 80, no. 5, p. 862-876.}

DOI: https://doi.org/10.1002/jwmg.1065

Background: Nest success is important to GRSG population growth, but factors that influence nest success vary spatially and temporarily. Assessments of disturbance, including energy development, on GRSG may be best informed by locally relevant measures of reproduction and habitat.

Objectives: The authors sought (1) to identify microsite features important to nest site selection, (2) to measure nest survival, and (3) to evaluate habitat factors that affected nest survival at three spatial scales around nests to characterize conditions prior to development of a wind energy facility.

Methods: The authors radio-tracked 47-55 female GRSG during each nesting season from 2011 to 2013 to identify nest habitats and measure nest survival. They measured structure and composition of vegetation at nest and non-nest sites for analyses of habitat at nest bowl and at patch (within 5 meters [m]), and area (within $30 \mathrm{~m}$ ) scales. Models of nest survival also accounted for weather conditions.

Location: southern Wyoming; MZ II

Findings: The percent of females that nested ranged from 80 to 94 percent across years. Big sagebrush provided cover for most nests (91.7 percent). Probability of selection of nest sites increased with visual obstruction (all scales) and sagebrush cover (patch scale) but decreased with increasing forb cover (area scale). Nest survival was positively correlated with grass height (patch and area scales) and visual obstruction (nest bowl), negatively correlated with the standardized precipitation-evapotranspiration index and a drought index from the preceding year, and included interactions or quadratic effects related to bunchgrass cover at patch and nest bowl scales.

Implications: Overall, the importance of microhabitat was scale independent within $30 \mathrm{~m}$ of nests. Management for structure and cover of grasses and for sagebrush can promote nest survival, particularly in drought years. This study provided data on nest survival before disturbance to assess potential effects of the Chokecherry and Sierra Madre Wind Energy Project facility.

Topics: behavior or demographics, effect distances or spatial scale, habitat selection, site-scale habitat characteristics, survival, weather and climate 


\section{Hansen, E.P., Stewart, A.C., and Frey, S.N., 2016, Influence of transmission line construction on winter sage-grouse habitat use in southern Utah: Human-Wildlife Interactions, v. 10, no. 2, p. 169-187.}

DOI: https://doi.org/10.26077/56cx-k645

Background: Transmission lines introduce vertical structures into GRSG habitats that can provide perches for avian predators, fragment habitat, and increase human activities. In some cases, the presence of transmission lines has explained extirpations or avoidance of specific areas by GRSG, but mechanisms are poorly understood.

Objectives: The authors sought to evaluate effects of adding a new transmission line to an existing energy corridor on the use of winter habitat by GRSG.

Methods: The authors used GPS transmitters to track 18 GRSG during winters of 2014-2015 and 2015-2016 after the construction of a new transmission line to compare with radio telemetry data collected from 19 different individuals in winter 2011-2012, before construction of the new line. The new transmission line was parallel to and in close proximity to an existing transmission line. The authors assessed effects of the new transmission line on winter habitat using resource selection functions with predictors of vegetation, topography, and anthropogenic disturbances. Changes in avoidance of the transmission corridor were measured by comparing shifts in minimum convex polygon centroids between pre- and post-construction datasets.

Location: southwestern Utah; MZ III

Findings: Resource selection functions predicted a 3 percent decrease in the relative probability of use of winter habitat by GRSG near the new transmission line after construction. However, centroids of winter home ranges did not shift away from the transmission line after construction. Visual inspection of telemetry locations also did not suggest any shift in locations away from the new transmission line after construction.

Implications: Placement of new transmission lines near existing transmission lines in marginal or poor habitat for GRSG probably minimizes negative effects. Estimates of effects in this study are conservative because avoidance of the original transmission line could not be evaluated. Inferences were applicable only to short-term effects and may not reflect indirect effects that manifest over longer periods of time.

Topics: conifer expansion, effect distances or spatial scale, habitat selection, infrastructure (roads, pipelines, powerlines, cell towers), new geospatial data, site-scale habitat characteristics 
*2019 Update* Hanser, S.E., Deibert, P.A., Tull, J.C., Carr, N.B., Aldridge, C.L., Bargsten, T.D., Christiansen, T.J., Coates, P.S., Crist, M.R., Doherty, K.E., Ellsworth, E.A., Foster, L.J., Herren, V.A., Miller, K.H., Moser, A., Naeve, R.M., Prentice, K.L., Remington, T.E., Ricca, M.A., Shinneman, D.J., Truex, R.L., Wiechman, L.A., Wilson, D.C., and Bowen, Z.H., 2018, Greater sage-grouse science (2015-17)-synthesis and potential management implications: U.S. Geological Survey, Open-File Report 2018-1017, p. 1-46.

DOI: https://doi.org/10.3133/ofr20181017

Background: Declines in GRSG abundance have led to the implementation of planning measures to promote GRSG conservation across their range, as well as considerable research to improve our understanding of the species. A summary of the major topics of importance within the current research is needed in order to better manage GRSG populations and their habitats.

Objectives: The objectives were to identify and explore important topics in recent research regarding GRSG and their habitats, and to derive relevant management implications from research findings.

Methods: The authors: 1) determined six primary topic areas of importance based on their expert knowledge regarding GRSG and their habitats, 2) reviewed an annotated bibliography of 169 GRSG research papers published from 2015 - 2017 to identify scientific papers that addressed the chosen topics, and 3) evaluated the science presented in the current research and determined potential management implications from research findings.

Location: Range-wide; MV I, MZ II, MZ III, MZ IV, MZ V, MZ VI, MZ VII

Findings: The six major topics identified are: 1) multiscale habitat suitability and mapping tools, 2) discrete anthropogenic activities, 3) diffuse activities, 4) fire and invasive species, 5) restoration effectiveness, and 6) population estimation and genetics. Recent research corroborates existing knowledge for many of these topics. Recent research also offers new findings, such as the relationship between grass height and GRSG nest success, warming trends that may warrant large-scale monitoring to target fire suppression, and suggestions to refine the current hunting season. There have also been advances in technology in the areas of genetics, geospatial data, and statistical modeling that have allowed for greater insight into issues such as population dynamics and mapping habitat characteristics.

Implications: Recent research has both substantiated previous knowledge regarding GRSG and their habitats and brought to light new insights that may aid in conserving GRSG in the future.

Topics: agricultural conversion, behavior or demographics, broad-scale habitat characteristics, conifer expansion, energy development, ex-urban development, fences, fire or fuel breaks, genetics, habitat restoration or reclamation, habitat selection, herbivory/grazing, hunting, infrastructure (roads, pipelines, powerlines, cell towers), mining, new geospatial data, non-native invasive plants, population estimates or targets, predators or predator control, range mgmt. structures (water developments, mineral licks), recreation, sagebrush removal, site-scale habitat characteristics, survival, translocation, weather and climate, wild horses and burros 


\section{*2019 Update* Harju, S.M., Olson, C.V., Hess, J.E., Bedrosian, B., 2018, Common raven movement and space use: influence of anthropogenic subsidies within greater sage- grouse nesting habitat: Ecosphere, v. 9, no. 7, article e02348, p. 1-16.}

DOI: https://doi.org/10.1002/ecs2.2348

Background: Raven populations have increased due to subsidies available in human impacted landscapes. Ravens are known to depredate GRSG nests, therefore understanding raven movements in relation to anthropogenic subsidies may help land managers in conserving GRSG.

Objectives: The authors sought to: 1) quantify how raven space use and movements are influenced by primary anthropogenic nesting and food subsidies during their breeding season, and 2) determine the impact of breeding status on raven space use, movement, and utilization of anthropogenic subsidies.

Methods: Data were collected during the raven breeding season from $2012-2014$. Twenty ravens were captured and fitted with GPS units that recorded locations in one-three hour intervals. Authors recorded: 1) the breeding status of each GPS-tagged raven, 2) nest locations of GPS-tagged and non-GPS-tagged ravens, and 3) whether nest substrate was a human-made or natural feature. Movements and space-use were quantified in relation to anthropogenic subsidies such as highways and landfills.

Location: Wyoming; MZ II

Findings: Ravens primarily utilized anthropogenic structures for nesting. Regarding space use, the authors found that breeding birds spent significantly more time near highways and railroads than did non-breeding or post-breeding birds, and that non-breeding birds visited primary subsidies significantly more than breeding and post-breeding birds. Analysis of movement revealed that: 1) breeding ravens traveled the least out of all birds surveyed, 2) post-nesting ravens with failed nests had similar space use to nonbreeding ravens, and 3) post-nesting ravens with successful nests had similar space use to breeding ravens.

Implications: Lethal control of ravens at primary subsidies likely does not impact breeding ravens, who tend to utilize these sources less and pose a greater threat to GRSG through nest depredation. Inducing nest failure may cause ravens to change their space use and movement patterns to a wider-ranging non-breeding pattern, which would likely leave them more vulnerable to lethal control at primary subsidies.

Topics: predators or predator control 


\section{Harmon, L., and Hirchert, D., 2016, Managing safety and wildlife at Jackson Hole Airport: Journal of Airport Management, v. 10, no. 4, p. 381-401.}

DOI: https://www.henrystewartpublications.com/jam/v10

Background: A GRSG lek is located within the runway safety area of the Jackson Hole Airport in Wyoming. Many collisions between aircraft and GRSG at the airport have been recorded in the Federal Aviation Administration's Wildlife Strike Database, which triggered the need for a Wildlife Hazard Management Plan.

Objectives: The authors' objective was to document the collaborative effort between air travel regulatory agencies, resource managers and scientists, and consultants to create a Wildlife Hazard Management Plan for the airport that addressed the needs of both aviation safety and GRSG populations.

Methods: The Jackson Hole Airport Board convened a collaborative Wildlife Hazard Working Group to develop a Wildlife Hazard Management Plan that would satisfy requirements of the traveling public and agencies while also benefiting GRSG.

Location: northwestern Wyoming; MZ II

Findings: The Wildlife Hazard Working Group identified four components to address the situation: (1) modify habitat to draw GRSG away from the runway, (2) restore habitat adjacent to the airport boundary, (3) restore offsite leks, and (4) perform long-term monitoring of effectiveness and GRSG population size.

Implications: All parties viewed this collaborative effort as a positive experience and as a model for future groups needing to compromise and collaborate to achieve needed change.

Topics: ex-urban development, habitat restoration or reclamation, human dimensions or economics, infrastructure (roads, pipelines, powerlines, cell towers), new geospatial data 


\section{Heinrichs, J.A., Aldridge, C.L., Gummer, D.L., Monroe, A.P., and Schumaker, N.H., 2018, Prioritizing actions for the recovery of endangered species-Emergent insights from greater sage-grouse simulation modeling: Biological Conservation, v. 218, p. 134-143.}

DOI: https://doi.org/10.1016/j.biocon.2017.11.022

Background: Understanding the potential effectiveness of actions taken to stabilize populations of declining species is often challenging because of short timelines for decision making, small population sizes, and the dynamic nature of the landscapes the species inhabit. Simulation models are a useful alternative to field-based experiments for evaluating potential effects of different species recovery efforts.

Objectives: Study objectives were (1) to develop a spatially explicit, individual-based population simulation model for GRSG, (2) to use this model to identify population sources and sinks and test their influence on alternative GRSG recovery planning scenarios, and (3) to suggest improvements to the modeling framework to better inform recovery planning.

Methods: The authors estimated GRSG demographic rates for the model using data from multiple field studies in the area across multiple years and modeled suitable habitat and individual movements and fates across the study area. The initial spatial distribution of simulated GRSG was based on lek locations and counts. Simulations were run for 35-50 years and replicated 100 times. GRSG abundance and persistence were quantified using multiple demographic rates, population scenarios, and scenarios of removal or restoration of sink habitats.

\section{Location: Alberta and Saskatchewan (Canada); MZ I}

Findings: No scenario produced an extinction risk of less than 0.5 , and no increase in a single demographic parameter resulted in a positive population growth rate. Demographic parameters that appeared more influential varied by population and included chick survival, adult survival, and the proportion of females re-nesting after a first failed nesting attempt. The majority of habitat in the study area functioned as a population source, but strong sinks were present. Simulated management actions on sink habitats resulted in population increases within 5 years, with restoration of chick survival conditions having the greatest effect.

Implications: This modeling framework, which mechanistically linked habitat conditions with populations, was able to provide insight into both potential types and targeting of recovery efforts. Results emphasized that recovery actions that improve multiple demographic parameters are needed to achieve positive population growth rates. Results also indicated the potential importance of habitat restoration efforts that target strong sinks and increase chick survival conditions and the overall capacity of the landscape, rather than removing sink habitats.

Topics: behavior or demographics, broad-scale habitat characteristics, habitat selection, new geospatial data, population estimates or targets, site-scale habitat characteristics, survival 


\section{Heinrichs, J.A., Aldridge, C.L., O'Donnell, M.S., and Schumaker, N.H., 2017, Using dynamic population simulations to extend resource selection analyses and prioritize habitats for conservation: Ecological Modelling, v. 359, p. 449-459.}

DOI: https://doi.org/10.1016/j.ecolmodel.2017.05.017

Background: Sage-grouse populations are highly dynamic over time and space, utilizing different habitats in different seasons. The interaction of habitat patterns, movement limitations, and population dynamics can influence predictions of important habitats and long-term population viability.

Objectives: The authors' objective was to compare habitats identified as priorities for GRSG by using either (1) resource selection functions alone or (2) resource selection functions in combination with a spatially explicit, individual-based population model.

Methods: The authors used resource selection functions developed for nesting, summer, and winter habitat in Wyoming from a previous study, updated with some new data. They used empirical abundance data from 2006 to initialize simulated GRSG populations. Movements, disease infection and mortality, and demographic rates for the individual-based population model were estimated based on the literature. Simulations were run for 60 time steps and replicated 50 times. Locations of simulated GRSG were mapped during nesting, summer, and winter to estimate the location and characteristics of valuable seasonal habitats.

Location: Wyoming; MZ I, MZ II

Findings: Results from the individual-based population model indicated that habitat connectivity was an important component of habitat suitability and use: centrally located habitats near dense populations were used more than isolated habitats. Simulated GRSG were more likely to use areas close to multiple seasonal habitats (summer, winter, and nesting). Changes in population density also affected habitat selection: small and decreasing populations used less of the landscape than was available according to resource selection functions. Large and fluctuating populations occupied more proximate and lower quality habitats.

Implications: Dynamic populations select habitat resources differently through time than minimally fluctuating populations. Habitat dynamics, connectivity, and behavior of individuals interact with population dynamics to refine resource selection. These results have implications for the size and location of habitat conservation and management activities.

Topics: behavior or demographics, broad-scale habitat characteristics, habitat selection, new geospatial data, site-scale habitat characteristics, survival 


\section{Heinrichs, J.A., Lawler, J.J., Schumaker, N.H., Wilsey, C.B., Newcomb, K., and Aldridge, C.L., 2017, A multispecies test of source-sink indicators to prioritize habitat for declining populations: Conservation Biology, Accepted Article posted November 29, 2017, 19 p.}

DOI: https://doi.org/10.1111/cobi.13058

Background: Habitat quality and population demographics can interact, resulting in source-sink dynamics whereby some subpopulations are highly productive and "export" individuals to neighboring areas and other subpopulations have more immigration and mortality than births. Understanding source-sink dynamics in GRSG may lead to more effective conservation by helping to identify the role of important habitats and associated demography on regional population outcomes.

Objectives: Study objectives were to investigate (1) the ability of different population metrics to identify important habitats, (2) the effects of different population sizes and trends on source-sink metrics, and (3) the effect of differences in the time period of data collection on habitat identification using demographic- and movement-based metrics.

Methods: The authors used a spatially explicit simulation model to simulate population dynamics from 2010 to 2020, calibrated with empirical data, to represent three species, including GRSG, with different population sizes and trends and different environmental conditions. Using this controlled environment, the authors manipulated habitats and compared metrics of abundance, productivity, and birth-immigration-death-emigration.

Location: Alberta (Canada); MZ I

Findings: Removal of important source habitats caused rapid decline in simulated GRSG populations. Simple metrics such as abundance were ineffective for identifying important GRSG habitats because of density effects and poor recruitment. The birth-immigration-death-emigration metric was most effective for identifying important GRSG habitats. Differences in habitat patterns, animal movement, and demographics affected metric performance and the importance of habitats.

Implications: A combination of metrics that includes abundance, movement, and demography may be required to accurately identify important habitats for conservation because of source-sink dynamics. The value and accuracy of indicator metrics may depend on the population trend, habitat conditions, and proportion of the population occupying sink habitats. Long-term data were not required for accurate predictions, but very short duration data reduced the ability of metrics to identify important habitats.

Topics: behavior or demographics, broad-scale habitat characteristics, habitat selection, survival 
*2019 Update* Heinrichs J.A., McKinnon D.T., Aldridge C.L., and Moehrenschlager A., 2019, Optimizing the use of endangered species in multi-population collection, captive breeding and release programs: Global Ecology and Conservation, v. 17, article e00558, p. 1-12.

DOI: https://doi.org/10.1016/j.gecco.2019.e00558

Background: Captive breeding and release programs are increasingly common as a conservation tool for imperiled species. Understanding the trade-offs among source, captive, and target populations is important to the success of these programs. Biologically-detailed, individual-based modeling approaches to assessing risks and benefits of conservation translocations can help optimize management and allocation of resources.

Objectives: The objectives were to assess: 1) the impacts of removing GRSG from their source populations, 2) the requirements for captive, sustainable GRSG populations, and 3) the impacts of GRSG re-introduction on the abundance of target populations.

Methods: GRSG eggs were collected from wild Canadian populations to initiate a captivebreeding program at the Calgary Zoo. Egg collection, captive breeding and release data, and potential breeding program plans were used to develop model simulations. Several individualbased models were developed to: 1) assess wild population responses to short- and long-term egg collection scenarios, 2) simulate the outcomes of various captive breeding scenarios, and 3) explore the degree to which releases of captive-bred chicks and juveniles would benefit wild population abundance and persistence. Models included information from known captive breeding programs and data describing wild populations including movement, survival, reproduction, habitat selection and leks.

Location: Alberta, Saskatchewan, Montana; MZ I

Findings: Impacts of simulated egg collection on wild population varied based on population trajectory, size, and collection intensity. Overall, simulated egg collection resulted in decreased Canadian populations, but populations in Montana did not decline. Most captive breeding simulations resulted in flocks that produced excess GRSG chicks that could be used to supplement wild populations. The simulated release of both chicks and juveniles improved wild population sizes and reduced extinction risk.

Implications: Simulation models can help increase understanding of trade-offs of captive breeding programs for imperiled species and give insight on how to best to allocate resources in high risk populations.

Topics: behavior or demographics, captive breeding, population estimates or targets, survival, translocation 


\section{*2019 Update* Heinrichs, J.A., O'Donnell, M.S., Aldridge, C.L., Garman, S.L., and Homer C.G., 2019, Influences of potential oil and gas development and future climate on sage- grouse declines and redistribution: Ecological Applications, v. 0, no. 0, article e01912, p. $1-16$.}

DOI: https://doi.org/10.1002/eap.1912

Background: There are many environmental stressors that influence wildlife, but little is known about the cumulative and combined impact of these stressors on wildlife populations. Wildlife management decisions would benefit from a predictive resource that could quantify multiple changes in the landscape over time and effectively link those changes to wildlife population outcomes.

Objectives: The objectives were to: 1) develop an approach to evaluate the influence of multiple landscape changes on future wildlife population outcomes, 2) assess the degree to which wildlife populations can withstand different kinds of direct and indirect impacts, 3) estimate how population predictions could change when multiple rather than individual stressors are considered, and 4) provide an example of how spatially explicit individual-based models can help to plan future landscapes that support wildlife populations.

Methods: Using a case study of GRSG, the authors explored 16 models including three types of projected landscape change including: 1) low, medium, or high oil and gas development scenarios for the years 2012 - 2062,2) change in vegetation due to climate through 2050, and 3) a combination of development and vegetation change. Model inputs included existing and projected locations of well pads and access roads, historical and projected climate-vegetation relationships, and known GRSG population and behavior data. GRSG habitat selection, movement, and population dynamics were then simulated for future landscape scenarios, and future population sizes were compared to equilibrium and legacy scenarios.

\section{Location: Wyoming; MZ II}

Findings: GRSG abundance decreased for all projected development-only scenarios and climate-only scenarios. When development and climate were examined together, GRSG population declines were greater than for either factor alone, and fewer areas had population gains. The degree and rate of population decline varied based on starting population size and level of simulated development, with higher development generally leading to greater declines.

Implications: In order to better predict the importance of incremental environmental stressors on future wildlife population dynamics, cumulative and combined effects of multiple stressors should be accounted for through both space and time.

Topics: behavior or demographics, energy development, habitat selection, infrastructure (roads, pipelines, powerlines, cell towers), population estimates or targets, sagebrush removal, weather and climate 


\section{*2019 Update* Henderson, E.B., Bell, D.M., and Gregory, M.J., 2019, Vegetation mapping to support greater sage-grouse habitat monitoring and management-Multi- or univariate approach? Ecosphere, vol. 10, no. 8, p. 1-22.}

DOI: https://doi.org/10.1002/ecs2.2838

Background: Accurate vegetation mapping is essential for effective GRSG management. However, habitat suitability is often predicted using stacked univariate vegetation maps, from vegetation layers that were constructed independently of one another. Although univariate maps can be very accurate, stacked maps contain covariance errors. Small biases in independent maps can combine to yield problematic aggregate vegetation summaries. It is important to understand which mapping approach more accurately characterizes vegetation with respect to GRSG habitat suitability in order to make more informed management decisions.

Objectives: The authors sought to: 1) evaluate univariate and multivariate vegetation mapping approaches, and 2) assess the outcomes of each approach when classifying habitat.

Methods: The authors analyzed existing rangeland vegetation monitoring data collected between 2009 and 2017 at 2,709 plots, and remotely sensed imagery, topography, climate and soils data layers. These data were used to compare univariate and multivariate vegetation modeling approaches.

\section{Location: Oregon; MZ IV, MZ V}

Findings: Both modeling approaches were similarly accurate at different scales, but the univariate approach had more bias. The univariate approach also underestimated species richness and developed some logical errors. Further, the univariate approach overestimated the percent of suitable GRSG habitat, while the multivariate approach underestimated it.

Implications: The multivariate modeling approach was better for describing the multiple dimensions of vegetation that describe GRSG habitat than the univariate approach. The authors argue that the multivariate approach can better inform GRSG habitat management decisions at mid- and broad scales.

Topics: broad-scale habitat characteristics, effect distances or spatial scale, non-native invasive plants, site-scale habitat characteristics 


\section{Holloran, M.J., Fedy, B.C., and Dahlke, J., 2015, Winter habitat use of greater sage-grouse relative to activity levels at natural gas well pads: Journal of Wildlife Management, v. 79, no. 4, p. 630-640.}

DOI: https://doi.org/10.1002/jwmg.877

Background: Oil and gas developments can negatively affect GRSG by reducing and fragmenting sagebrush habitats, introducing anthropogenic structures into sagebrush habitats, and increasing anthropogenic activities in sagebrush habitats. Several studies have documented the effects of energy development on GRSG, but mechanistic understanding of GRSG avoidance remains inadequate to identify modifications to energy developments that could minimize effects.

Objectives: The authors sought to evaluate use of winter habitat by GRSG across gas field infrastructure (1) densities and (2) proximities in areas where producing gas wells were categorized as either conventional or connected to offsite liquid gathering systems (which decrease human activity levels at wells).

Methods: The authors used a network of receivers and data loggers distributed throughout a natural gas field to radio-track 236 GRSG during winters from 2005 to 2010 . They related the number of GRSG visiting and the time GRSG spent in areas around each data logger to infrastructure variables (summarized within 2.8 kilometers $[\mathrm{km}]$ of the data logger) and habitat characteristics that included shrub height, shrub cover, and topography.

\section{Location: southwestern Wyoming; MZ II}

Findings: Use of suitable winter habitat by GRSG decreased with increasing density of gas wells within $2.8 \mathrm{~km}$ of data loggers. Habitat use also increased with distance to wells and plowed main haul roads, but well density was a better predictor. Effects of anthropogenic activity were evident at lower well densities, and some evidence suggested that GRSG avoided conventional wells more strongly than those connected to liquid gathering systems.

Implications: Effects of gas development on GRSG can be reduced by minimizing well densities and adopting methods that reduce anthropogenic activities, such as the use of wells that are connected to liquid gathering systems. Effects of anthropogenic activity may have a time lag because GRSG avoidance of drilling rigs often continued at wells equipped with liquid gathering systems, but the lag time at those wells was not as long as the lag time documented at conventional wells.

Topics: broad-scale habitat characteristics, effect distances or spatial scale, energy development, habitat selection, infrastructure (roads, pipelines, powerlines, cell towers), site-scale habitat characteristics 
Homer, C.G., Xian, G., Aldridge, C.L., Meyer, D.K., Loveland, T.R., and O'Donnell, M.S., 2015, Forecasting sagebrush ecosystem components and greater sage-grouse habitat for 2050-Learning from past climate patterns and Landsat imagery to predict the future: Ecological Indicators, v. 55, p. 131-145.

DOI: https://doi.org/10.1016/j.ecolind.2015.03.002

Background: Water-limited ecosystems are sensitive to changes in temperature and precipitation. Forecasts of precipitation over the next century include changes that can alter vegetation communities that provide habitat for many wildlife species in the sagebrush ecosystem, including GRSG.

Objectives: Study objectives were (1) to model effects of precipitation on cover of vegetation components and bare ground in sagebrush ecosystems, (2) to predict changes to vegetation components and bare ground through 2050, and (3) to evaluate associated changes to GRSG habitat quantity and quality.

Methods: The authors estimated cover of sagebrush, herbaceous vegetation, bare ground, litter, and shrub cover from 1984 to 2011 with Landsat and QuickBird imagery. Next, they related downscaled precipitation data from each year to changes in sagebrush vegetation and soil components with linear models. Then, they predicted cover components in 2050 using two International Panel on Climate Change forecasts of precipitation as inputs to their linear models. Finally, they predicted habitat suitability for GRSG in 2050 based on the predicted amounts of sagebrush and herbaceous cover.

Location: southwestern Wyoming; MZ II

Findings: All measured vegetation and soil cover components were significantly correlated with annual precipitation. From 1984 to 2011, amounts of bare ground increased, whereas all other components decreased. Predicted patterns in measured components to 2050 were similar to historic trends. Models predicted losses of 12 percent of suitable nesting habitat and 4 percent of summer habitat for GRSG in 2050 relative to 2006.

Implications: Predicted losses of GRSG habitat through changes in precipitation were significant and reveal the sensitivity of a region with a robust sagebrush ecosystem to future climate change. Methods can be extended to other wildlife species and across broad geographic extents because predictions are based on satellite imagery.

Topics: broad-scale habitat characteristics, new geospatial data, site-scale habitat characteristics, weather and climate 


\section{Hopken, M.W., Orning, E.K., Young, J.K., and Piaggio, A.J., 2016, Molecular forensics in avian conservation-A DNA-based approach for identifying mammalian predators of ground-nesting birds and eggs: BMC Research Notes, v. 9, article 14, 9 p.}

DOI: https://doi.org/10.1186/s13104-015-1797-1

Background: Nest predation is one factor affecting GRSG reproductive success, but identifying nest predators can be challenging. An understanding of important predators may affect management decisions.

Objectives: The authors used DNA collected from predator saliva found on depredated nests to identify the species responsible.

Methods: The authors used telemetry data to locate GRSG nests around three lek complexes and monitored nests, using cameras to confirm nest predators. Fourteen nests and seven hen carcasses were recovered and sampled after predation. DNA was collected from shells and carcasses in a laboratory. Mitochondrial and nuclear DNA was amplified and analyzed.

Location: Wyoming; MZ II

Findings: The most common nest and hen predators were canids; other identified nest or hen predators included striped skunk, deer mouse, and cattle. Coyotes were connected to 6-7 nests, and dogs to 3 nests. Coyotes were connected to 3-4 of 7 hen deaths. DNA identification did not always agree with field cues and camera evidence. Depredation by domestic dogs was an unexpected result, as the study site was $>30$ miles from the nearest populated area.

Implications: DNA sampling of depredated nests offers a complementary method to traditional, camera-based methods. Sample contamination, secondary consumers, and limitations of DNA libraries may have limited study results. Avian DNA was not considered in this study, but the authors reported that this would be feasible. The methods used here may help identify to what extent predation, or specific species of predators, may be affecting GRSG populations.

Topics: predators or predator control 
Howe, K.B., and Coates, P.S., 2015, Observations of territorial breeding common ravens caching eggs of greater sage-grouse: Journal of Fish and Wildlife Management, v. 6, no. 1, p. $187-190$.

DOI: https://doi.org/10.3996/042014-JFWM-030

Background: Nest predation is a common cause of reproductive failure and can significantly affect population dynamics. Ravens are known nest predators of GRSG, but rates of depredation by individual ravens and their influence on GRSG populations are poorly understood.

Objectives: The authors sought to characterize frequency of GRSG egg depredations by individual ravens.

Methods: In this research note, the authors describe opportunistic observations on three nest sites of ravens that depredated GRSG eggs. Observations took place during a habitat study for ravens from 2007 to 2009 and another ongoing study of GRSG demographics.

Location: southeastern Idaho, north-central Nevada; MZ IV

Findings: Nesting ravens appeared to depredate multiple GRSG nests. The number of depredated GRSG eggs found around raven nests in any single visit ranged from 3 to 17 . Repeat visits to raven nests revealed newly depredated GRSG eggs within time intervals as short as 1 day on multiple occasions, suggesting that ravens frequently targeted GRSG nests. The authors also documented ravens caching whole GRSG eggs.

Implications: Ravens can significantly influence reproductive success of GRSG at local scales, but population-level effects remain unclear. Breeding ravens may target GRSG nests more than nonbreeders. Declines of GRSG may be compounded by anthropogenic activities that have improved nesting habitat for ravens in sagebrush ecosystems.

Topics: predators or predator control 


\section{Jahner, J.P., Gibson, D., Weitzman, C.L., Blomberg, E.J., Sedinger, J.S., and Parchman, T.L., 2016, Fine-scale genetic structure among greater sage-grouse leks in central Nevada: BMC Evolutionary Biology, v. 16, article 127, 13 p.}

DOI: https://doi.org/10.1186/s12862-016-0702-4

Background: Genetic structure of animal populations can reveal patterns in movement, population vulnerability, and capacity of species to adapt to environmental perturbations. High fidelity of GRSG to leks and breeding dominance by strong individuals yield population genetic structures, which can advance our understanding of GRSG population dynamics and habitat requirements.

Objectives: The authors sought (1) to characterize genetic structure of GRSG across leks and lek complexes and (2) to evaluate the importance of habitat suitability and geography for genetic differentiation.

Methods: The authors analyzed DNA from 140 male GRSG captured across 10 leks from 2007 to 2012. They estimated genotype probabilities for each GRSG and used three complementary ordination procedures to assess variation among individuals. They then tested for differences in genotype probabilities among leks and lek complexes and related genotypic variation to geography, habitat connectivity, and anthropogenic infrastructure. Finally, they assessed samplesize requirements for robust evaluation of genetic structure and importance of geography.

Location: central Nevada; MZ III

Findings: Lek complexes and leks separated by $>30$ kilometers were genetically distinct, and individuals within leks were highly related. Geographic distance best explained genetic distance, followed by habitat suitability. Anthropogenic infrastructure did not affect genetic structure. Robust analyses of genetic structure for GRSG can be obtained from approximately 4,000 singlenucleotide polymorphisms.

Implications: Fine-scale genetic variation can indicate GRSG responses to lek geography, habitat suitability, and anthropogenic features. GRSG lek mating systems and lek fidelity may limit genetic differentiation and gene flow. All have the potential to increase our understanding of the effects of habitat, behavior, and gene flow on the genetic diversity of GRSG and inform future management actions.

Topics: broad-scale habitat characteristics, genetics, infrastructure 


\section{Jones, T.A., 2017, Impacts on ecosystems, corrective restoration practices, and prospects for recovery-Nine case studies in the continental United States: The Rangeland Journal, Online Early article posted October 6, 2017, 20 p.}

DOI: https://doi.org/10.1071/RJ17021

Background: Many large-scale restoration efforts are currently underway to reverse environmental degradation, restore ecosystem services and wildlife populations, and repair soil and water resources. Restoration of sagebrush ecosystems following the 2015 Soda Fire is one such effort.

Objectives: Objectives of this review were to examine current restoration efforts and identify for each (1) the disturbances and effects leading to a need for restoration, (2) the restoration actions applied, and (3) the prospects for recovery of ecosystem services, including wildlife.

Methods: The author selected nine significant restoration efforts conducted in terrestrial and riparian ecosystems and large watersheds. One case study focused on restoration of sagebrush in the Great Basin, particularly following the Soda Fire, which burned 280,000 acres in August 2015.

Location: southwestern Idaho, southeastern Oregon; MZ IV

Findings: The restoration effort was driven by wildfire and the need to restore habitat for GRSG. Rehabilitation was guided by the U.S. Department of the Interior's Secretarial Order 3336, which was intended to protect sagebrush by controlling the spread of annual invasive grasses that contribute to more frequent and disastrous wildfires. A 5-year response plan to the fire was developed by a group of Federal and State resource management agencies. The plan authorized the application of herbicides and the construction of fire breaks and facilitated monitoring. Restoration focused on big sagebrush and native forbs and included drilling seeds, aerial seedings, and transplanting seedlings. Efforts have increased knowledge of techniques for successful restoration of Wyoming big sagebrush. Restoration efforts at higher elevations in the Great Basin are focused on controlling expansion of conifers into sagebrush communities.

Implications: Large-scale, high-profile restoration efforts across diverse ecosystems contribute to the body of research needed to inform successful restoration in the future. They also demonstrate how multiple stakeholders can work together toward restoration goals that may also decrease the likelihood of additional regulations being imposed.

Topics: conifer expansion, fire or fuel breaks, habitat restoration or reclamation, nonnative invasive plants 


\section{Juliusson, L.M., and Doherty, K.E., 2017, Oil and gas development exposure and conservation scenarios for greater sage-grouse-Combining spatially explicit modeling with GIS visualization provides critical information for management decisions: Applied Geography, v. 80, p. 98-111.}

DOI: https://doi.org/10.1016/j.apgeog.2017.01.006

Background: Development of oil and gas reserves is one of the land uses affecting GRSG habitat in Greater sage-grouse Management Zones (MZs) I and II. Understanding risk to GRSG from future development is important for managing this risk and determining conservation status of GRSG.

Objectives: This study sought (1) to map probability of oil and gas development, (2) to provide estimates of GRSG exposure to development based on future development scenarios, and (3) to provide estimates of exposure reduction from proposed conservation actions.

Methods: The authors used three development scenarios (low, baseline, high) based on recoverable resource assessments and current development patterns and described risk to GRSG based on overlap with GRSG breeding habitats and populations. The authors then assessed the reduction in exposure to development based on State and Federal conservation commitments (State of Wyoming Core Area Strategy, Bureau of Land Management land-use plans).

Location: Colorado, Montana, North Dakota, South Dakota, Utah, Wyoming; MZ I, MZ II

Findings: Spatial modeling of development potential produced a probability of development surface which accurately depicted recent development (1994-2014) based on historic patterns (1900-1993). The model was used to project development into the future. An index of GRSG population distribution and maps of breeding habitats combined with development potential indicated that 12-25 percent of breeding habitats in this region may be exposed to development in the future. When exposure was reduced through Bureau of Land Management and Wyoming Core Area restrictions, 6-14 percent of breeding habitats remained at risk. Between 15 and 27 percent of GRSG populations may be exposed to energy development in the future, but State and Federal conservation actions may reduce that to 5-17 percent. The range in projections reflects differences between MZs I and II and between baseline and high development scenarios.

Implications: Risk to GRSG from oil and gas development is not uniform across MZs I and II. Bureau of Land Management land-use plans and the State of Wyoming Core Area Strategy vary in management actions, but they may similarly reduce risks to GRSG populations and breeding habitats. Visualization tools enabled spatial assessment of locations where potential exposure risk is elevated across the management zones.

Topics: broad-scale habitat characteristics, energy development 


\section{*2019 Update* Kämmerle, J.L., and Storch, I., 2019, Predation, predator control and grouse populations: a review: Wildlife Biology, article wlb.00464, p. 1-12.}

DOI: https://doi.org/10.2981/wlb.00464

Background: Many mammalian and avian predators contribute to grouse mortality and are thought to limit population sizes. Because several species of grouse are of conservation concern, predator control is often used as a conservation tactic. However, this approach remains a controversial topic as quantitative evidence to support its effectiveness is lacking.

Objectives: The objectives were to: 1) review the literature to determine if predation acts as a limiting factor for grouse populations, 2) quantify the effectiveness of predator control in benefiting various grouse population parameters, and 3) identify gaps of knowledge in the literature.

Methods: A literature search, through August 2017, for "grouse predator control" was conducted using Google Scholar and the Web of Science. A total of 15 studies that investigated predatorinduced population limitations were qualitatively reviewed. A total of 12 studies, four in North America, that assessed the effectiveness of predator control on population parameters were quantitatively reviewed. All predator control studies occurred between 1931 - 2013. Data were extracted from publications, processed into a test statistic, and analyzed.

Location: Europe, New York, Texas, Utah, Wyoming; MZ II, MZ III

Findings: Most studies indicated that grouse populations are limited by predation. There appears to be a relationship between habitat suitability or environmental conditions and the relative impact of predation. Predator control studies varied widely in their design, measurements, and spatial-scale. Overall, predator control had a positive effect on most parameters - pooled adult abundance and survival and number of chicks per hen - but not on nest success or brood size. Population parameters increased by a mean of 1.4 times reference values.

Implications: Well-designed predator control programs are likely to cause short-term benefits to various grouse species. However, more research is needed, particularly on how the competitive interactions of predator species influence grouse predation risk and whether removing certain predator species may have unintended cascading effects.

Topics: predators or predator control, survival 


\section{Kane, K., Sedinger, J.S., Gibson, D., Blomberg, E., and Atamian, M., 2017, Fitness landscapes and life-table response experiments predict the importance of local areas to population dynamics: Ecosphere, v. 8, no. 7, article e01869, 19 p.}

DOI: https://doi.org/10.1002/ecs2.1869

Background: Habitats used by GRSG can vary with their life history stage because resources needed for early growth are not necessarily the same as resources needed to maintain energy in adults. Life-table response experiments provide a tool to relate habitat characteristics to population growth rates through habitat effects on demographic rates.

Objectives: Study objectives were to evaluate contributions of life stage-specific habitats to population dynamics of GRSG through an extended application of life-table response experiments.

Methods: The authors modeled habitat and assessed habitat contributions to GRSG population dynamics using 350 nests monitored for nest success, 28 lek locations, and randomly selected points without GRSG that were collected from 2003 to 2012. They developed spatial models of nest site selection, nest survival, chick survival, and female survival to map predicted responses across the study area. Probability of a site being selected for nesting and demographic rates derived from models functioned as inputs to a Leslie matrix to assess their relative contributions to population growth rates.

Location: central Nevada; MZ III

Findings: About 8 percent of the study area functioned as source habitat for GRSG. Suitable nesting habitat differed from habitats that supported adult survival. Population growth rates were sensitive to adult survival, but chick survival explained the most variation in population dynamics, followed by nest site selection. Population growth was associated with mid- to highelevation areas with high sagebrush cover, moderate slopes, and nesting areas close to late brood-rearing habitats.

Implications: A relatively small proportion of the available GRSG habitat in this study is responsible for maintenance of the population. Conservation of these limited habitats (late-brood habitat in this study) may be an effective short-term strategy to manage imperiled species. The approach used in this study can inform conservation strategies for GRSG by identifying specific habitats that contribute to population growth of GRSG.

Topics: behavior or demographics, habitat selection, new geospatial data, site-scale habitat characteristics, survival 


\section{Kirol, C.P., Beck, J.L., Huzurbazar, S.V., Holloran, M.J., and Miller, S.N., 2015, Identifying greater sage-grouse source and sink habitats for conservation planning in an energy development landscape: Ecological Applications, v. 25, no. 4, p. 968-990.}

DOI: https://doi.org/10.6084/m9.figshare.c.3296837.v1

Background: Habitat quality for GRSG is most reliably defined as a function of fitness responses in addition to occurrence, rather than occurrence or abundance alone. Identifying habitats that contribute to population growth is especially important to address effects of increasing energy development in GRSG habitat.

Objectives: The authors sought to develop maps of habitat quality for GRSG based on fitness models and habitat characteristics at multiple spatial scales.

Methods: The authors radio-tracked 150 female GRSG in a natural gas development from 2007 to 2009 to measure habitat use, survival, and reproduction. These measures formed responses in habitat models that evaluated the importance of vegetation, topography, and energy infrastructure extracted from areas of $0.25,1$, and 5 square kilometers around sample points. Evaluations of reproduction included separate analyses of nesting, early brood rearing, late brood rearing, early nonbrooding, and late nonbrooding. Survival analyses included nest, brood, and adult females in summer. Synthetic habitat surfaces derived from these analyses used weighting based on contributions of demographic components to population growth or integration of models for reproduction to estimate habitat quality.

\section{Location: southern Wyoming; MZ II}

Findings: Environmental predictors associated with habitat selection varied across seasons and according to whether females were brooding or not. The addition of anthropogenic infrastructure variables improved models; all top habitat selection models included well or road variables. Energy infrastructure had negative effects on habitat use and brood survival, with brood survival decreasing once surface disturbance exceeded 4 percent. Based on independent lek data, 70 percent of active leks were located in areas that were identified as primary or secondary source habitat.

Implications: Results suggest that reduction of habitat quality was primarily driven by avoidance of energy infrastructure, resulting in primary and secondary source habitat becoming low-occurrence habitat. Source-sink maps from this study can inform future siting of energy infrastructure and potential mitigation actions. Maintenance of source habitat in proximity to energy developments may improve colonization of reclaimed sites following energy extraction. Methods to develop these maps are applicable to other species of concern.

Topics: behavior or demographics, broad-scale habitat characteristics, effect distances or spatial scale, energy development, habitat selection, infrastructure (roads, pipelines, powerlines, cell towers), new geospatial data, site-scale habitat characteristics, survival 


\section{*2019 Update* Kirol, C.P., Pilgrim, K.L., Sutphin, A.L., and Maechtle, T.L., 2018, Using DNA from hairs left at depredated greater sage-grouse nests to detect mammalian nest predators: Wildlife Society Bulletin, v. 42, no. 1, p. 160-165.}

DOI: https://doi.org/10.1002/wsb.853

Background: One of the leading causes of nest failure among GRSG is nest depredation, however little is known about which mammalian predators influence nest productivity and how these predator communities may change in human-modified landscapes. Current methods for surveying nest predators are often cost prohibitive, invasive, or impractical at larger spatial scales, creating a need for more efficient and less invasive survey methods.

Objectives: The authors sought to: 1) determine if using DNA collected from hair left at depredated nests is a practical method to identify GRSG nest predators, and 2) describe the composition of the local predator community influencing GRSG nest productivity.

Methods: During the nesting season over a three-year span from 2009 to 2011, 228 GRSG nests were monitored every $2-6$ days until they hatched. If a nest was determined to have been depredated, any hairs found in the nest shrub were collected. DNA was extracted from hair samples and used to genetically identify the species of origin.

Location: Wyoming; MZ I, MZ II

Findings: Nearly half of nests monitored were unsuccessful, and approximately one third of failed nests had hair that was found and successfully genetically identified. Five species of predator were detected from hair samples: coyote, American badger, red fox, striped skunk, and bobcat. Two predators identified, red fox and striped skunk, are considered exotic in the study area.

Implications: This study presents a novel, non-invasive, and cost-effective survey method that minimizes collection bias and can be used at larger spatial scales to gain insight on mammalian predators that influence GRSG nest productivity. It can also help to identify exotic predators that benefit from human subsidies and habitat modification. This method could be expanded to include other forms of DNA, such as feathers or saliva, for greater inference.

Topics: other topic, predators or predator control 


\section{Kirol, C.P., Sutphin, A.L., Bond, L., Fuller, M.R., and Maechtle, T.L., 2015, Mitigation effectiveness for improving nesting success of greater sage-grouse influenced by energy development: Wildlife Biology, v. 21, no. 2, p. 98-109.}

DOI: https://doi.org/10.2981/wlb.00002

Background: Much energy development in the West is occurring on Federal lands, managed by the Bureau of Land Management, that also provide important habitat for GRSG. Bureau of Land Management base requirements for onsite mitigation are intended to minimize negative effects of that development on wildlife, but they appear inadequate for maintaining stable GRSG populations. Additional mitigation strategies (beyond the base requirements) may include strategies for reducing vehicle traffic, open-water reservoirs, sagebrush removal, aboveground power lines, construction of roads and well pads, and noise. No previous study has evaluated the effectiveness of such mitigation strategies based on nest success, a major factor in GRSG population dynamics.

Objectives: The authors sought (1) to evaluate effectiveness of onsite mitigation strategies for natural gas developments on GRSG nest success and (2) to determine aspects of natural gas infrastructure that influence nest success.

Methods: The authors radio-tracked female GRSG from 2008 to 2011 to monitor success (that is, $\geq 1$ egg hatched) of 301 nests in a natural gas field. Nest sites were categorized as within mitigated development, within nonmitigated development, on the periphery of development, or outside of development. The authors evaluated mitigation effects with models that related nest success to environmental and anthropogenic predictors extracted from geographic information system (GIS) layers within $0.35,1,2$, and 5 square kilometers $\left(\mathrm{km}^{2}\right)$ around nest locations. Anthropogenic predictors included counts of wells and well pads; distances to nearest well, road, power line, and waterbody; and total amount of roads, power lines, water edge, and surface disturbance.

Location: northern Wyoming; MZ I

Findings: After accounting for environmental conditions, nest success was highest in unaltered areas, followed by mitigated sites and then unmitigated sites. There was limited evidence of effects from specific energy infrastructure variables on nest success after accounting for environmental conditions and different levels of mitigation. The best model did include the amount of water edge (from energy or livestock watering reservoirs or perennial water drainages), suggesting that nest success decreased with increasing amounts of water edge within $5 \mathrm{~km}^{2}$. The amount of water edge at unmitigated sites was approximately double that of mitigated sites.

Implications: Onsite mitigation of natural gas development improves nest success. Minimizing reservoirs appears to be the most effective mitigation measure because of reduced risk to West Nile virus and nest predators associated with water, including raccoons and skunks. 
Topics: behavior or demographics, broad-scale habitat characteristics, effect distances or spatial scale, energy development, habitat selection, infrastructure (roads, pipelines, powerlines, cell towers), site-scale habitat characteristics 
Koch, R.E., Krakauer, A.H., and Patricelli, G.L., 2015, Investigating female mate choice for mechanical sounds in the male greater sage-grouse: The Auk, v. 132, no. 2, p. 349-358.

DOI: https://doi.org/10.1642/AUK-14-63.1

Background: Mate choice in GRSG is influenced by male displays that include vocalizations and sounds produced from wing movements. Previous studies have analyzed variation in vocalizations, but complex acoustics from wing movements that create a sonic swish may also contribute to displays that determine mate choice.

Objectives: Study objectives were to evaluate (1) the role of sounds created by wing movement by GRSG in male mating success and (2) how these sounds vary across courtship conditions.

Methods: The authors observed, filmed, and audio-recorded breeding displays and copulations of 67 male GRSG on a lek during the breeding seasons of 2006 and 2007. They used the program Raven to extract nine acoustic measures from each swish to compare acoustics within and among wing movements of individual males and analyze breeding success as a function of acoustics. They also tracked the distance to the nearest female for each male display.

Location: central Wyoming; MZ II

Findings: Most acoustic characteristics of swishes differed among male GRSG. None of the acoustic characteristics directly explained breeding success. However, successful males had a larger ratio of frequency range to duration in the second swish compared to unsuccessful males. Successful males also varied this ratio based on their distance to females.

Implications: Breeding displays of male GRSG include swishes that may draw attention to other display components or signal dominance to other males. Acoustic signals derived from mechanical movements are common among birds and likely influence their fitness.

Topics: behavior or demographics 
Kohl, K.D., Connelly, J.W., Dearing, M.D., and Forbey, J.S., 2016, Microbial detoxification in the gut of a specialist avian herbivore, the greater sage-grouse: FEMS Microbiology Letters, v. 363, no. 14, article fnw144, 6 p.

DOI: https://doi.org/10.1007/s00360-015-0890-z

Background: Gut microbes in some herbivores can metabolize defensive compounds found in plants, thereby enabling a species to forage on plants unavailable to others. Sagebrush is a major food source for GRSG and is highly toxic, but the mechanisms by which GRSG can metabolize sagebrush are poorly understood.

Objectives: The authors sought to evaluate the role of microbial detoxification of plant secondary metabolites in GRSG relative to the domestic chicken and to mammalian herbivores.

Methods: The authors identified DNA of microbes present in the cecal microbiome of three GRSG through a metagenomic analysis of GRSG collected during fall and winter of 2012, when sagebrush is a primary forage species. They compared abundances of microbial genes classified by function in GRSG to those documented in previous studies of the domestic chicken and 15 mammalian herbivores.

Location: southern Idaho; MZ IV

Findings: Gut microbes of GRSG have genes associated with metabolizing toxic compounds found in sagebrush, analogous to capabilities observed in other bird and mammalian herbivores. Similar to other birds, most microbes in GRSG were bacterial, but many microbes that metabolize defensive compounds in plants differed in abundance between GRSG and other herbivores in this study. In GRSG, abundances of microbes that extract amino acids, degrade xenobiotics, and metabolize terpenoids were high relative to other herbivores. Presence of Arthrobacter in GRSG may enable conversion of phenols to pyruvate as an energy source.

Implications: The ability to consume plants that are toxic to other species can confer competitive advantages and ensure abundant food resources. Cecal microbiomes of GRSG may provide unique enzymes useful for improving palatability of toxic plants for herbivores in agriculture.

Topics: other 
Kohl, K.D., Pitman, E., Robb, B.C., Connelly, J.W., Dearing, M.D., and Forbey, J.S., 2015, Monoterpenes as inhibitors of digestive enzymes and counter-adaptations in a specialist avian herbivore: Journal of Comparative Physiology B-Biochemical Systemic and Environmental Physiology, v. 185, no. 4, p. 425-434.

DOI: https://doi.org/10.1007/s00360-015-0890-z

Background: Monoterpenes are chemical compounds found in plants that discourage animal consumption through digestive inhibition. Sagebrush is rich in monoterpenes, and GRSG prefer plants with lower monoterpene content. One common mode of action for plant toxins is to inhibit digestive enzymes, thus limiting nutrient availability to animals. In response, many animals produce enzymes that are resistant to inhibition by plant toxins. These trends have not been explored before in avian herbivores or with monoterpenes (a class of plant toxin).

Objectives: Study objectives were to evaluate and compare the susceptibility of digestive enzymes in GRSG and domestic chickens to inhibition by monoterpenes.

Methods: The authors examined monoterpenes and the contents of digestive tracts from 11 GRSG collected by hunters during winter 2011-2012. They also extracted intestinal tissue from 3 GRSG collected in late 2012 and 4 domestic chickens for enzyme assays. They conducted enzyme assays in the presence of extracts from black sagebrush and Wyoming big sagebrush, including monoterpenes, to assess their inhibition of the digestive enzyme aminopeptidase- $\mathrm{N}$ (APN). Finally, the authors compared inhibition curves for varying concentrations of seven monoterpenes between 3 GRSG and 4 chickens.

Location: Idaho; MZ IV

Findings: Inhibition of APN depended on bird species and monoterpene concentration, resulting in a 32 to 78 percent reduction in enzyme activity for three of seven monoterpenes. Inhibition from some monoterpenes was significantly lower in GRSG than chickens. Both species of sagebrush inhibited APN in chickens but not in GRSG. Within a bird species, inhibition effects did not differ between sagebrush species.

Implications: GRSG may select sagebrush with low concentrations of monoterpenes to maintain levels compatible with their absorptive capacity. Lack of inhibition differences between sagebrush species suggests that discrimination of monoterpene concentrations within species is important and may influence habitat selection.

Topics: other 
*2019 Update* Kohl, M.T., Messmer, T.A., Crabb, B.A., Guttery, M.R., Dahlgren, D.K., Larsen, R.T., Frey, S.N., Liguori, S., and Baxter, R.J., 2019, The effects of electric power lines on the breeding ecology of greater sage-grouse: Plos One, v. 14, no. 1, p. E0209968.

DOI: https://doi.org/10.1371/journal

Background: The effects of power lines on GRSG populations are not well understood and difficult to separate from the effects of energy development and other infrastructure. Because of this, best management practices for power lines in GRSG habitat are often inconsistent.

Objectives: The authors sought to: 1) evaluate the effects of power lines on GRSG breeding ecology, including leks, habitat use, and reproductive success, and 2) identify effective power line buffer distances.

Methods: The authors monitored radio-marked GRSG females in order to locate nests, determine hatching success, and track broods. These data and existing GRSG lek location and count data from 1998 to 2013 provided by the Utah Division of Wildlife Resources were analyzed in comparison with power distribution and transmission line locations, percent sagebrush cover, elevation, and distance to roads.

Location: Idaho, Utah, Wyoming; MZ II, MZ III, MZ IV

Findings: Proximity to transmission lines appeared to have a negative effect on lek use trends, nest-site selection, nest success, and brood success at distances up to $2.4 \mathrm{~km}$. The authors demonstrate the negative impacts of transmission lines and they suggest that higher percent of sagebrush cover may mediate these effects. In contrast, the authors did not find significant evidence for any effects on GRSG by distribution lines.

Implications: The authors proposed $2.3 \mathrm{~km}$ buffer zones around active leks as a best management practice for new transmission line construction. They also proposed site-specific management for distribution lines, and colocation with existing disturbances for all new power lines. Maintenance of sagebrush cover around power lines may improve GRSG habitat suitability, despite the presence of human disturbance.

Topics: behavior or demographics, effect distances or spatial scale, habitat selection, infrastructure (roads, pipelines, powerlines, cell towers), sagebrush removal 
Kormos, P.R., Marks, D., Pierson, F.B., Williams, C.J., Hardegree, S.P., Havens, S., Hedrick, A., Bates, J.D., and Svejcar, T.J., 2017, Ecosystem water availability in juniper versus sagebrush snow-dominated rangelands: Rangeland Ecology and Management, v. 70, p. 116-128.

DOI: https://doi.org/10.1016/j.rama.2016.05.003

Background: Western juniper has invaded significant portions of the sagebrush ecosystem. Ecological consequences of this transition are likely complex because of associated changes to ecohydrology that influence vegetation and habitat of GRSG.

Objectives: The authors compared catchments dominated by juniper versus sagebrush to determine (1) differences in snow distribution and water delivery, (2) effects on water balance and stream flow, and (3) potential ecological consequences of transitioning from sagebrush to juniper woodland ecosystems.

Methods: Within four catchments dominated by juniper and for water years 2008 to 2013, the authors estimated juniper cover and daily snow-water equivalent, snow melt, and snow-water input with the iSnobal model that accounted for topography, vegetation, weather, and energy inputs. Adjustments based on previous sagebrush studies allowed model estimates of snow parameters on the same catchments with cover by sagebrush. The authors also measured stream discharge at four water control devices (weirs) for analysis of juniper systems and modeled discharge from a water balance equation for the sagebrush analysis.

Location: southeastern Idaho; MZ IV

Findings: Juniper-dominated systems had higher peak snow accumulation but more rapid melt out than sagebrush systems. Water delivery was earlier, evapotranspiration was higher, and stream discharge was lower in juniper systems compared to sagebrush systems.

Implications: The ability of sagebrush systems to retain water, relative to juniper systems, has important implications for vegetation, including grasses and forbs that contribute to habitat quality for GRSG. Conservation of sagebrush communities at high elevations with significant snow may be important for sustaining GRSG habitat under a warming climate.

Topics: conifer expansion 
Krakauer, A.H., Blundell, M.A., Scanlan, T.N., Wechsler, M.S., McCloskey, E.A., Yu, J.H., and Patricelli, G.L., 2016, Successfully mating male sage-grouse show greater laterality in courtship and aggressive interactions: Animal Behaviour, v. 111, p. 261-267.

DOI: https://doi.org/10.1016/j.anbehav.2015.10.031

Background: Lateral body orientation of animals toward potential mates or competitors is common among species and may enhance communication or perception. Frequently, GRSG exhibit lateral orientation at leks during the breeding season, but little is known about biases in lateral orientation and contributions to breeding success.

Objectives: The authors sought to determine (1) whether male GRSG exhibited bias in lateral body orientation and (2) whether laterality conferred fitness benefits.

Methods: The authors observed and recorded behavior and copulations of 42 male GRSG at a lek during the breeding season in 2007. For each agonistic interaction, observers recorded the physical orientation as right or left eye facing the target. For courtship displays, observers recorded the angle of the strutting male in relation to the nearest female.

Location: central Wyoming; MZ II

Findings: Successful breeders exhibited a left-eye bias during agonistic facing-past encounters, whereas there were no biases during fights. Strutting males had a right-eye bias of $38^{\circ}$. Lateral biases of successful breeders differed from nonbreeders, as did whether they used their lateral (monocular) or frontal (binocular) fields. Biases varied with distance from females for nonbreeders.

Implications: Identifying and understanding lateral biases can be challenging because of the context dependency of behaviors, as exhibited by GRSG. Nevertheless, GRSG exhibit these biases, which may arise from sexual selection.

Topics: behavior or demographics 


\section{Kreuter, U.P., Wolfe, D.W., Hays, K.B., and Conner, J.R., 2017, Conservation credits- Evolution of a market-oriented approach to recovery of species of concern on private land: Rangeland Ecology and Management, v. 70, no. 3, p. 264-272.}

DOI: https://doi.org/10.1016/j.rama.2016.10.012

Background: Strategies such as the Endangered Species Act of 1973 that are geared towards the recovery of imperiled species can discourage landowners from protecting important habitats because of uncompensated restrictions on land use. Conservation efforts for GRSG could benefit from using market-based approaches to recover rare species in regions dominated by private lands.

Objectives: Study objectives were (1) to describe market-based conservation, (2) to evaluate applications to golden-cheeked warblers and dunes sagebrush lizards, and (3) to assess applications to lesser prairie chickens and GRSG.

Methods: The authors presented strengths and weaknesses of market-based strategies that were implemented to recover endangered golden-cheeked warblers and dunes sagebrush lizards. A flowchart and conceptual figure summarized stakeholder interactions and processes of the Recovery Credit System. Finally, the authors discussed a habitat exchange program implemented for lesser prairie chickens that has been proposed to aid conservation of GRSG.

Location: California, Colorado, Idaho, Montana, Nevada, North Dakota, Oregon, South Dakota, Utah, Washington, Wyoming; MZ I, MZ II, MZ III, MZ IV, MZ V, MZ VI, MZ VII

Findings: The Leon River Restoration Project was an incentive-based proof-of-concept program to improve habitat for golden-cheeked warblers on private lands. The Recovery Credit System allowed Fort Hood to offset golden-cheeked warbler habitat losses by funding habitat protections on private lands. The Conservation Recovery Award System set up a credit system whereby private landowners earned credits for conserving dunes sagebrush lizard habitat, which could then be sold to various entities that could not avoid negatively affecting dunes sagebrush lizard habitat. A habitat exchange program for lesser prairie chickens provides income to landowners who conserve habitat to mitigate actions of energy companies and others that negatively affect habitat.

Implications: The large geographic range of GRSG has good potential to supply credits for a market-based strategy. Success depends on whether programs can transform endangered species from liabilities to assets for private landowners.

Topics: human dimensions or economics 


\section{LeBeau, C.W., Beck, J.L., Johnson, G.D., Nielson, R.M., Holloran, M.J., Gerow, K.G., and McDonald, T.L., 2017, Greater sage-grouse male lek counts relative to a wind energy development: Wildlife Society Bulletin, v. 41, no. 1, p. 17-26.}

DOI: https://doi.org/10.1002/wsb.725

Background: Wind energy developments may affect GRSG through the introduction of infrastructure, habitat disturbance, and anthropogenic activity. Wind infrastructure has been associated with lower reproductive success in GRSG, which has raised concern about potential effects on other aspects of GRSG populations.

Objectives: Study objectives were to quantify effects of wind energy infrastructure on the number of GRSG males attending leks within an area influenced by wind energy infrastructure.

Methods: The authors counted male GRSG at five leks near wind infrastructure and nine leks in a control area between 2006 and 2016. They tested effects of wind infrastructure on mean maximum lek counts by using a before/after/control/treatment study design that accounted for repeated measures of the number of males attending leks across years. They considered time lags and conducted a power analysis to determine effect sizes that could be detected with 80 percent power.

\section{Location: south-central Wyoming; MZ II}

Findings: All lek counts were in decline prior to development, but there were no negative differences in the relative trends in males attending leks at the treatment compared to the control areas between the pre- and post-development periods. There was a significant drop in males attending leks at the treatment area compared to the control area when the authors assumed that the effect of developed occurred 3 years following development (that is, a 3-year lag), but the overall trends were not significant.

Implications: There was little evidence that development of the wind energy facility negatively affected GRSG lek counts 8 years later. While a lack of predevelopment data limited the authors' ability to estimate an effect size if the effect occurred during the first year following development, power was sufficient to detect small effect sizes when they considered time lags, especially multiple years following development. Effects of wind infrastructure were not evident beyond 1.5 kilometers $(\mathrm{km})$ from a turbine, but the authors suggest caution in recommending any avoidance buffers less than $1.5 \mathrm{~km}$ because of the potential that this study may have failed to detect a real effect (Type II error). Information on survival and habitat selection may provide a more complete assessment of potential effects of wind energy infrastructure on breeding male GRSG.

Topics: behavior or demographics, effect distances or spatial scale, energy development 


\section{LeBeau, C.W., Johnson, G.D., Holloran, M.J., Beck, J.L., Nielson, R.M., Kauffman, M.E., Rodemaker, E.J., and McDonald, T.L., 2017, Greater sage-grouse habitat selection, survival, and wind energy infrastructure: Journal of Wildlife Management, v. 81, no. 4, p. 690-711.}

DOI: https://doi.org/10.1002/jwmg.21231

Background: Wind energy facilities may affect wildlife directly through collision mortality from turbines or indirectly through habitat alteration and human activities. The introduction of vertical structures to prairie habitats and human activity associated with wind energy developments may affect GRSG negatively, but research specific to wind infrastructure and GRSG is extremely limited.

Objectives: Study objectives were to evaluate effects of wind energy development on seasonal survival and habitat selection of GRSG.

Methods: The authors radio-tracked 346 female GRSG from multiple leks between 2009 and 2014 on Seven Mile Hill in a treatment area (0.5-4.1 kilometers [km] from nearest turbine) and a control area $(>7.1 \mathrm{~km}$ from nearest turbine). The authors used discrete choice models to test for effects of wind infrastructure on habitat selection during nesting, brood rearing, and summer periods; they used Cox proportional hazard models to test whether nest, brood, or adult survival was related to wind energy infrastructure. Habitat selection and survival models included a suite of vegetation metrics (for example, herbaceous and sagebrush cover), environmental metrics (for example, elevation, topography), and anthropogenic metrics (for example, distance to nearest turbine, road, and transmission line) quantified at multiple spatial scales up to $3.2 \mathrm{~km}$.

Location: south-central Wyoming; MZ II

Findings: Nest site selection was not related to wind energy infrastructure variables, and females continued to select nest sites in and around the facility 6 years following development. Selection of brood rearing and summer habitat decreased with increasing surface disturbance within 1.2 $\mathrm{km}$ of wind energy facility infrastructure. Nest and brood survival rates were not related to wind energy infrastructure variables. Female survival was positively related to the percentage of disturbance within $0.81 \mathrm{~km}$ of the wind energy facility infrastructure.

Implications: GRSG appeared to select nest sites without regard to wind energy infrastructure but avoided such infrastructure during brood rearing and summer. Stronger effects of disturbance associated with wind energy on brood-rearing habitat selection in the later time period suggest a lagged population-level response. GRSG survival did not appear to be negatively affected by the facility.

Topics: behavior or demographics, effect distances or spatial scale, energy development, habitat selection, infrastructure (roads, pipelines, powerlines, cell towers), new geospatial data, survival 
*2019 Update* LeBeau, C.W., Smith, K.T, Holloran, M.J. Beck, J.L., Kauffman, M.E., and Johnson G.D., 2019, Greater Sage-grouse habitat function relative to 230-kV transmission lines: The Journal of Wildlife Management, p. 1-14.

DOI: https://doi.org/10.1002/jwmg.21749

Background: GRSG use large, intact sagebrush landscapes throughout the year. Habitat loss and fragmentation from energy generation, transmission, and distribution can potentially have adverse effects on GRSG populations.

Objectives: The goal of this study was to assess the effects of energy transmission lines on GRSG habitat selection and demographics.

Methods: The authors monitored 346 radio-marked female GRSG over six years in two different locations. They quantified habitat suitability prior to estimating power line effects to remove potentially confounding effects of habitat conditions and power line locations.

Location: Wyoming: MZ I, MZ II

Findings: Transmission lines had negative effects on GRSG survival, with the magnitude of these effects depending on habitat quality and the distance from transmission lines to leks. Nearby $(<3.1 \mathrm{~km})$ occupied leks, transmission lines had negative effects extending out $1 \mathrm{~km}$ from the lines. Farther than $3.1 \mathrm{~km}$ from leks, transmission line impacts were evident for $0.5 \mathrm{~km}$ out from lines.

Implications: The authors suggest that future transmission line placement decisions should consider potential negative effects on GRSG habitat and demographics and that transmission lines should be located in areas of lower GRSG habitat suitability and greater than $3.1 \mathrm{~km}$ from occupied leks if possible.

Topics: behavior or demographics, broad-scale habitat characteristics, effect distances or spatial scale, energy development, habitat selection, human dimensions or economics, infrastructure (roads, pipelines, powerlines, cell towers), survival 


\section{LeBeau, C.W., Strickland, M.D., Johnson, G.D., and Frank M.S., 2017, Landscape-scale approach to quantifying habitat credits for a greater sage-grouse habitat conservation bank: Rangeland Ecology and Management, advance online proof posted December 8, 2017, 9 p. \\ DOI: https://doi.org/10.1016/j.rama.2017.10.004}

Background: Understanding habitat selection and use is important for conservation and management of GRSG, including development of habitat conservation banks. The Greater SageGrouse Habitat Conservation Bank in central Wyoming is the largest habitat bank in the United States and the first for GRSG. There was a need to confirm that GRSG use this bank year round and to assess the value of habitats within the bank.

Objectives: The goals of this study were (1) to describe habitat use by GRSG within and around the Greater Sage-Grouse Habitat Conservation Bank, (2) to identify seasonal habitats within the area, and (3) to translate habitat selection into a habitat conservation credit system based on habitat importance.

Methods: The authors captured and used telemetry to track 109 GRSG in and near the Greater Sage-Grouse Habitat Conservation Bank in 2010, 2011, and 2014. They used high-resolution habitat mapping, field observations, and existing spatial data to model habitat conditions and a resource selection function to model habitat use patterns.

Location: central Wyoming; MZ II

Findings: The GRSG population was nonmigratory, selecting seasonal habitats in close proximity to each other ( $<5$ kilometers) across multiple seasons. Proximity to leks was an important predictor of habitat selection in all seasons, and elevation was included in final models for all seasons as well. Distances to the nearest road (positive effect) and the nearest transmission line (negative effect) were also important in seasonal models. Vegetation characteristics were important during breeding and summer seasons. GRSG selected lower sagebrush height during breeding and selected for variability in sagebrush height in both breeding and summer seasons. GRSG also selected breeding areas with higher cover of herbaceous vegetation, rabbitbrush, and Wyoming big sagebrush. Greasewood, rabbitbrush, silver sagebrush, and Nebraska sedge were higher in summer habitat use areas. Habitat conservation credits were defined on the basis of the highest breeding, summer, or winter habitat use value for that hectare of habitat.

Implications: GRSG in this area selected habitats similar to those described across the region and in the literature, but they also selected some conditions not described elsewhere. Some of these results may relate to characteristics of the remotely sensed data used to quantify vegetation characteristics, the distribution of GRSG in the study area in relation to anthropogenic features, or issues of scale. The value of developing habitat selection models specific to a population of interest was documented, and such models were necessary to estimate the conservation value of the bank.

Topics: behavior or demographics, broad-scale habitat characteristics, habitat selection, human dimensions or economics, infrastructure (roads, pipelines, powerlines, cell towers) 


\section{Lockyer, Z.B., Coates, P.S., Casazza, M.L., Espinosa, S., and Delehanty, D.J., 2015, Nest-site selection and reproductive success of greater sage-grouse in a fire-affected habitat of northwestern Nevada: Journal of Wildlife Management, v. 79, no. 5, p. 785-797.}

DOI: https://doi.org/10.1002/jwmg.899

Background: Habitat protection is a primary component of conservation strategies for GRSG, and wildfire is a major threat to habitat in many regions. Few studies have examined GRSG habitat selection in a landscape recovering from fire or assessed how such degraded habitat may influence demographic rates like survival and reproduction.

Objectives: The authors sought to evaluate the importance of vegetation and topography to GRSG nest site selection and nest survival at multiple spatial scales in an area recovering from a wildfire that occurred in 1999.

Methods: The authors radio-tracked 71 GRSG from 2009 to 2011 to identify nest sites and monitor nest survival. They characterized habitat at the nest bowl and within microhabitat spatial scales of $0.01,0.03,0.2,0.8$, and 3.1 hectares (ha). Using geographic information system (GIS) data, they characterized habitat at macrohabitat spatial scales of 39, 148, 617, 2,470, and 15,527 ha around sample points. These data were inputs for a series of resource selection functions that assessed the influence of vegetation characteristics on nest site selection and nest survival.

Location: northwestern Nevada; MZ V

Findings: Nest sites had greater total shrub cover (that is, both sagebrush and non-sagebrush shrubs) and less cheatgrass compared to random points. Nest survival increased with total shrub cover. Results suggested slow recovery from fire has limited habitat suitability for GRSG.

Implications: Habitat management for all shrub species, rather than just sagebrush, may confer the greatest benefits to GRSG. Reproductive success of GRSG may be improved by maintaining perennial grasses and $>40$ percent shrub cover within 0.8 ha of nest sites. Cheatgrass control may also improve nest success. GRSG may benefit from postfire restoration that recovers shrubs and perennial grasses.

Topics: behavior or demographics, broad-scale habitat characteristics, habitat selection, sitescale habitat characteristics 
*2019 Update* Luna, T., Mousseaux, M.R., and Dumroese, R.K., 2018, Common native forbs of the northern Great Basin important for Greater Sage-grouse: U.S. Department of Agriculture, Forest Service, Rocky Mountain Research Station, General Technical Report RMRS-GTR-387, $76 \mathrm{p}$.

DOI: https://www.fs.usda.gov/treesearch/pubs/57500

Background: This identification guide describes a variety of common forbs that are important for GRSG hen and chick diets, either as a food source or because they support invertebrates that GRSG consume.

Objectives: The authors intended this field guide to assist in identifying forbs during GRSG habitat assessment and vegetation monitoring efforts.

Methods: Native forbs are arranged by family and alphabetically by genus and species. Entries include photographs, a detailed description of the plant, and how it is used by GRSG. A ranked list of all included forbs and other plant genera that are important to GRSG is included in an appendix.

Location: range-wide; MZ I, MZ II, MZ III, MZ IV, MZ V, MZ VI, MZ VII

Findings: The top three most important plant species groups for GRSG are sage shrubs, other desert shrubs, and dandelion-like flowers with milky sap. Sagebrush, rabbitbrush, and horsebrush are the most important plants for both food and cover.

Implications: This guide may assist in the management of forbs and other vegetation in order to promote GRSG conservation.

Topics: behavior or demographics, other topic 


\section{Mabray, S.T., and Conover, M.R., 2015, Microhabitat selection by greater sage-grouse hens during brood rearing: Human-Wildlife Interactions, v. 9, no. 2, p. 219-228.}

DOI: https://doi.org/10.26077/483t-pf76

Background: Brood rearing is an important life history stage for GRSG because of high chick mortality rates, especially during the first three weeks of life. Habitats used during this time must provide GRSG chicks with both food and shelter from avian predators.

Objectives: The study sought to determine (1) whether hens with and without broods selected different microhabitats or exhibited different predator avoidance strategies during early broodrearing periods compared to late brood-rearing periods, and (2) whether there were habitat differences between sites occupied by hens and sites where hens were preyed upon.

Methods: The authors collected radio telemetry data from 40 female GRSG across 11 study areas 16 to 24 kilometers in diameter from late March to July 2012. Vegetation and avian predator surveys were conducted at 75 hen locations, 92 random locations, and 7 hen depredation locations.

Location: southwestern Wyoming; MZ II

Findings: Sites selected by hens during the early brood-rearing season had higher shrub cover, higher visual obscurity, and lower densities of avian predators than random sites. Hens without broods avoided sites with ravens or American kestrels during the early brood season, but hens with broods did not. Shrub cover and predator densities influenced site selection by hens in the late brood-rearing season. Only hens with broods avoided sites with avian predators during the late brood-rearing season. There were no differences in any tested variables found among five sites of hen mortality and random sites.

Implications: Although both factors were important, nest site selection during brood rearing appeared to be more strongly related to predator avoidance metrics than to vegetation characteristics, especially during the late brooding season. The authors suggest that GRSG avoid areas that they perceive as risky, such as areas with avian predators and anthropogenic structures.

Topics: behavior or demographics, habitat selection, predators or predator control, site-scale habitat characteristics 


\section{Maestas, J.D., Campbell, S.B., Chambers, J.C., Pellant, M., Miller, R.F., 2016, Tapping soil survey information for rapid assessment of sagebrush ecosystem resilience and resistance: Rangelands, v. 38, no. 3, p. 120-128.}

DOI: https://doi.org/10.1016/j.rala.2016.02.002

Background: Large-scale wildfire and invasion by nonnative annual grasses threaten sagebrush ecosystems across the western United States. Concepts of resistance and resilience of sagebrush ecosystems and data that map them can help managers better understand drivers of change in these systems, identify risks associated with future exposure to fire or invasion, design management treatments, and prioritize areas for treatment application.

Objectives: The authors sought to describe newly aggregated soils datasets and tools and to demonstrate how land managers can use both to help assess potential resistance and resilience of GRSG habitats.

Methods: The authors described the data foundation of the resistance and resilience classifications, a geodatabase developed to provide associated data across the GRSG range, and the potential use and utility of these data at local to regional scales.

Location: California, Idaho, Nevada, Oregon, Utah, Washington; MZ III, MZ IV, MZ V, MZ VI

Findings: Two sources of soils data, SSURGO and STATSGO2, are the foundation of resistance and resilience classification and maps. SSURGO (Soil Survey Geographic Database) was the primary foundation, and STATSGO2 (Digital General Soil Map of the United States) accounted for 17 percent of the project area. Both soil datasets were developed by the U.S. Department of Agriculture Natural Resources Conservation Service. Aggregating soil survey data allowed for the first visual representation of the potential resilience and resistance gradient underlying GRSG management zones using soil taxonomic temperature and moisture regimes as indicators. The geodatabase provides key soils information (such as soil temperature and moisture regimes) and other data (such as mean annual air temperature and precipitation) across the GRSG management zones and can function as a simplified tool for landscape triage when managing risks of fire and invasive annual grass conversion. A new soils report, part of the online Web Soil Survey (https://websoilsurvey.sc.egov.usda.gov/), was also developed to allow managers to rapidly extract relevant soils data for assessing resistance and resilience at the site scale.

Implications: Soil survey information is valuable for putting resistance and resilience concepts into practice in sagebrush ecosystems. Regional datasets have been provided for large-scale applications, and a soils report tool is now available to support site-scale planning. Combining soils data with information on biotic factors, such as vegetation, provides a powerful framework for managing fire and invasive species risks.

Topics: broad-scale habitat characteristics, fire or fuel breaks, new geospatial data, non-native invasive plants, site-scale habitat characteristics 
*2019 Update* Mathews, S.R., Coates, P.S., Prochazka, B.G, Ricca, M.A., Meyerpeter, M.B., Espinosa, S.P., Lisius, S., Gardner, S.C., and Delehanty, D.J., 2018, An integrated population model for Greater Sage-grouse (Centrocercus urophasianus) in the Bi-State Distinct Population Segment, California and Nevada, 2003-17: US Geological Survey Open-File Report 2018-1177, 89 p.

DOI: https://doi.org/10.3133/ofr20181177

Background: The Bi-State GRSG Distinct Population Segment (DPS) was not listed under the Endangered Species Act due to management actions prescribed under the Bi-State Action Plan. Per this plan, the USGS led an interagency research effort to monitor and manage the Bi-State GRSG DPS.

Objectives: The authors sought to: 1) quantify GRSG responses to management by identifying population trends and assessing habitat associations, and 2) enhance GRSG populations through an experimental translocation program.

Methods: Across nine sub-populations in the Bi-State DPS, GRSG individuals, nests, and leks were monitored between 2003 and 2017. Rate of population change was modeled for each subpopulation and across the Bi-State DPS during these years. In addition, in 2017 the authors translocated 25 GRSG to restore a subpopulation in Parker Meadows. Of 17 translocated females, three were transported with their broods, or brood translocations, and represented a novel technique in GRSG translocations.

Location: California, Nevada; MZ III

Findings: Monitoring and tracking yielded detailed maps and descriptions of GRSG use and home ranges across the Bi-State DPS. Habitat association results suggested that GRSG use increased following pinyon-juniper conifer removal treatments. Modeling results reflected annual variations among sub-populations, with an overall two percent decline in abundance across the Bi-State DPS from 2003 to 2017. Translocation efforts resulted in a low probability of survival of translocated individuals, with most translocated grouse dying or dispersing away from the release area.

Implications: The overall decline in the Bi-State DPS was likely a result of drought events; subpopulations that are stable or increasing are insulated from drought due to water availability. Two translocated broods survived more than 40 days after relocation and the authors suggest that moving females with their broods may increase brood recruitment by translocated birds.

Topics: conifer expansion, habitat restoration or reclamation, new geospatial data, population estimates or targets, site-scale habitat characteristics, survival, translocation 


\section{McCaffery, R., and Lukacs, P.M., 2016, A generalized integrated population model to estimate greater sage-grouse population dynamics: Ecosphere, v. 7, no. 11, article e01585, $14 \mathrm{p}$.}

DOI: https://doi.org/10.1002/ecs2.1585

Background: Estimating population trends in a consistent manner across subpopulations is difficult for species like GRSG, which occur in multiple geographically distinct areas across a broad range. Raw counts of individuals are often used to assess trends at broad scales, whereas studies incorporating demographic rates, which are important for explaining changes in population size, are difficult to quantify beyond local scales. A modeling approach that can combine these disparate data sources to better estimate population trends and more accurately assess which demographic parameters are most responsible for changes would benefit management and conservation efforts for GRSG.

Objectives: Study objectives were (1) to develop an integrated GRSG population model, capable of providing range-wide, precise demographic estimates and predicting future population dynamics, and (2) to determine which model parameters should be targeted in future GRSG sampling efforts in order to improve model performance.

Methods: The authors used existing data on male lek attendance at $>1,700$ Montana leks visited between 2002 and 2014 and demographic data from 50 studies spanning 1938-2011 across the range of the species to develop statewide and local integrated population models estimating annual GRSG population growth rate and size.

Location: Montana; MZ I, MZ II, MZ IV

Findings: Integrated population models improved estimates of annual GRSG population dynamics by smoothing variability attributable to sampling noise. In Montana, mean population growth rate decreased as the sex ratio became skewed in favor of hens but was less sensitive to change in age ratio. Average annual population growth rate indicated a decline over this time period.

Implications: The authors conclude that their integrated population model framework could provide robust assessments of population size and trend, information on mechanisms underlying observed trends, and a unified tool for use by GRSG biologists studying various populations throughout the range of the species. The authors suggest that future field sampling efforts should seek improved information on sex and age ratios, female population sizes, sex-specific survival rates by life stage, and the proportion of leks surveyed annually in a given area.

Topics: behavior or demographics, population estimates or targets 


\section{McCaffery, R., Nowak, J.J., and Lukacs, P.M., 2016, Improved analysis of lek count data using N-mixture models: Journal of Wildlife Management, v. 80, no. 6, p. 1011-1021.}

DOI: https://doi.org/10.1002/jwmg.21094

Background: Declines in GRSG populations have resulted in a need for increasingly rigorous, range-wide population size and trend estimates. Counting males at leks is the most common means of GRSG population monitoring, but there is uncertainty regarding how trends in male lek count data relate to true trends in GRSG populations.

Objectives: This study sought to examine the efficacy of using $N$-mixture models to analyze male lek count data in order to estimate population size, detection probability, and lek count trends.

Methods: The authors first conducted simulations to assess the effect of missing lek count data on population growth rate estimates; they then estimated male population sizes and trends using lek count data collected at two spatial scales between 2002 and 2014.

Location: Montana; MZ I, MZ II, MZ IV

Findings: $N$-mixture models accurately recovered population growth rate estimates, even when up to 90 percent of the input data were withheld in simulations and regardless of whether detection probability was held constant or allowed to vary among years. The authors found that $N$-mixture models produced more accurate population trend estimates than naive lek count data, largely because they corrected for substantial year-to-year variability in detection probability.

Implications: Using naive lek count data may result in inaccurate and misleading estimates of GRSG population size and trend when compared to results obtained by using an $N$-mixture modeling approach that can better account for variable detection probability and missing data. The authors provide suggestions for lek monitoring designs that can be analyzed using $N$-mixture models.

Topics: population estimates or targets 


\section{Miller, R.F., Naugle, D.E., Maestas, J.D., Hagen, C.A. and Hall, G., 2017, Special issue- Targeted woodland removal to recover at-risk grouse and their sagebrush-steppe and prairie ecosystems: Rangeland Ecology and Management, v. 70, no. 1, p. 1-8,}

DOI: https://doi.org/10.1016/j.rama.2016.10.004

Background: Woodland expansion is considered a widespread threat affecting functions and values across sagebrush and prairie ecosystems of the western United States. GRSG and lesser prairie chickens have become primary drivers of woodland management. Conifer removal treatments are one of few practical options available to managers to increase the availability of suitable GRSG habitat. Despite the scale of targeted conifer and mesquite treatment for grouse, scientific evaluations of the effects of this approach on grouse, other nontarget species, and ecosystem aspects have been lacking.

Objectives: The authors sought to summarize findings from contributed articles in this special issue of Rangeland Ecology and Management on woodland expansion and targeted removal of conifers and mesquite to recover at-risk grouse (GRSG and lesser prairie chickens) and the sagebrush and prairie ecosystems they inhabit.

Methods: The authors summarized key findings from 14 contributed manuscripts in the special issue regarding expansion of woodlands in sagebrush and prairie ecosystems, including effects on plants, birds, and hydrology.

\section{Location: western United States}

Findings: Articles in the issue highlighted the importance of a broad-scale perspective to management of top-down threats, the utility of high-resolution tree canopy cover maps encompassing broad areas for assessing woodland expansion status and quantifying effects of woodland reduction treatments, and the value of cooperative conservation efforts. Benefits of woodland management include increased GRSG habitat availability for nesting and brood rearing, changes in GRSG behavior and demographics, maintenance of native grassland and sagebrush plant communities, conservation of nontarget sagebrush-obligate birds, and improved water capture, storage, and release.

Implications: GRSG and lesser prairie chickens have become primary drivers for addressing the woodland expansion threat. The article illustrates the utility of GRSG and lesser prairie chickens as flagship species for implementing ecosystem restoration at ecologically meaningful scales, which can help sustain broader ecosystem functions and values.

Topics: conifer expansion, habitat restoration or reclamation 


\section{Monroe, A.P., Aldridge, C.L., Assal, T.J., Veblen, K.E., Pyke, D.A., and Casazza, M.L., 2017, Patterns in greater sage-grouse population dynamics correspond with public grazing records at broad scales: Ecological Applications, v. 27, no. 4, p. 1096-1107,}

DOI: https://doi.org/10.1002/eap.1512

Background: Livestock grazing can affect the suitability of areas for wildlife species that rely on shared habitats. Most studies that have investigated these effects, however, have been short term and conducted at local spatial scales that may not capture how grazing effects on wildlife change across gradients of precipitation, soil, and plant productivity.

Objectives: The goal of this study was to examine how GRSG populations respond to differences in livestock grazing timing and intensity across a gradient of plant productivity.

Methods: The authors used public grazing records and a remotely sensed vegetation productivity index to model trends in male GRSG lek count data from 2004 to 2014 among 743 Wyoming leks.

Location: Wyoming; MZ I, MZ II

Findings: GRSG populations increased when higher grazing levels occurred later in the year, following the peak vegetation productivity, but populations decreased when higher grazing levels occurred during or prior to this peak. Findings support the notion that the effects of grazing on GRSG may vary depending on local vegetation productivity.

Implications: High levels of grazing in this study represent intensities near maximum allowable levels defined by the Bureau of Land Management. Study findings did not suggest that reducing these grazing levels would benefit GRSG populations, but rather that grazing may have both positive and negative effects on GRSG, depending on timing and intensity. Study results suggest that broad-scale analyses are important to capture the range of responses that wildlife can have to land-use and livestock management. These findings could also help guide sustainable livestock management decisions, such as delaying high-level grazing until after peak vegetation productivity, in similar habitats.

Topics: broad-scale habitat characteristics, herbivory/grazing, new geospatial data, population estimates or targets 
Monroe, A.P., Edmunds, D.R., and Aldridge, C.L., 2016, Effects of lek count protocols on greater sage-grouse population trend estimates: Journal of Wildlife Management, v. 80, no. 4, p. 667-678.

DOI: https://doi.org/10.1002/jwmg.1050

Background: Counts of male GRSG attending leks are a primary means of monitoring population trends throughout their range. To improve data quality from lek counts, standardized methods have been employed. However, there is not a strong consensus on the time of day to which standardized lek counts should be limited.

Objectives: The authors' objectives were (1) to determine how GRSG population trend estimates are affected by extending the timing of lek count surveys by up to 30 minutes before and 90 minutes after sunrise, and (2) to identify how these effects varied with the spatial scale of lek data used, number of leks monitored, timing of monitoring, and number of visits per year to a given lek.

Methods: This study analyzed male lek count data collected at 348 Wyoming leks from 1995 to2014. The authors compared GRSG population trend estimates derived from lek surveys conducted within 30 minutes of sunrise to estimates derived from surveys that were conducted 30 minutes before to 60 minutes after or 30 minutes before to 90 minutes after sunrise.

Location: Wyoming; MZ I, MZ II

Findings: Precision of population trend estimates did not increase by limiting input data to only those surveys conducted within 30 minutes of sunrise. However, survey timing became more important as the number of leks or number of visits per lek decreased. Lek attendance decreased after 30 minutes from sunrise, but including data from these later surveys increased the number of leks monitored and, consequently, the precision of estimates without lowering accuracy.

Implications: Lek count data from surveys conducted within 90 minutes of sunrise can be used to estimate population trends without reducing the precision or accuracy of estimates, but future surveys should optimize survey timing based on spatial scale of desired inference and monitoring goals.

Topics: population estimates or targets 


\section{*2019 Update* Monroe, A.P., Wann, G.T., Aldridge, C.L., and Coates, P.S., 2019, The importance of simulation assumptions when evaluating detectability in population models: Ecosphere, v. 10, no. 7, p. 1-17.}

DOI: https://doi.org/10.1002/ecs2.2791

Background: Long-term, broad-scale monitoring is important for ecological research. However, detection probability is often assumed to be constant or random, when in reality, variability in detectability occurs. This results in potential biases when modeling populations. Evaluating variations in detection probability in GRSG population models may help increase overall model accuracy.

Objectives: The authors sought to assess how well GRSG population models perform under scenarios with and without annual trends in detection probability.

Methods: From 2012 to 2017, the authors captured 79 males at eight study sites, determined their ages, fit them with GPS units, and tracked their position relative to leks from January to June of each year. The authors then used observed lek attendance rates to simulate lek counts and population dynamics, comparing these simulated data with modeled population size and rate of change under varying trends in detection probability.

Location: Nevada; MZ III, MZ IV

Findings: All models underestimated population sizes but were similarly accurate in estimating population trends when detectability was constant across years. When detectability declined across years, accounting for variations in detection probability using repeated counts generally increased accuracy in population trend estimates, but bias increased as fewer sites were repeatedly counted. Incorporating auxiliary data also improved model accuracy.

Implications: Using simulation scenarios with systematic trends in detectability may be more informative for evaluating population models than scenarios that assume detectability is constant or random. With finite monitoring resources, using auxiliary data on lek attendance to model GRSG populations may allow more leks to be studied less intensively. However, additional investigation is needed to evaluate the extent to which auxiliary data are appropriate for different GRSG populations across their range.

Topics: behavior or demographics, population estimates or targets 


\section{Newton, R.E., Tack, J.D., Carlson, J.C., Matchett, M.R., Fargey, P.J., and Naugle, D.E., 2017, Longest sage-grouse migratory behavior sustained by intact pathways: Journal of Wildlife Management, v. 81, no. 6, p. 962-972.}

DOI: https://doi.org/10.1002/jwmg.21274

Background: Migratory routes of wide-ranging species can be disrupted by human land use, leading to increased costs of travel, mortality, and isolation. Maintaining connectivity for migratory species such as GRSG requires an understanding of which landscapes the species uses and how it uses them.

Objectives: The objectives of this study, which focused on a GRSG population with the longest known annual migration, were to assess (1) which habitats were used by GRSG, and how they were used, during migration and (2) how the population's migratory behavior was influenced by a particularly snowy winter.

Methods: The authors used GPS transmitters to track daily movements of 35 GRSG as they migrated in the autumn, winter, and spring between seasonal ranges. The authors related these movement data to geographic information system (GIS) land cover, topographic, and human use variables and modeled migratory resource selection at the population level after accounting for differences among individuals.

Location: Saskatchewan (Canada), north-central Montana; MZ I

Findings: Migratory routes used by individual GRSG varied, and individuals tended to move in a stepping stone manner. GRSG preferred to move through rolling grassland and flat sagebrush habitats and avoided cropland. Autumn migration consisted of traveling 41-126 kilometers (km) over 14 days, with nine different 1-day stopovers on average. Birds dealt with an unusually heavy snowpack by making an additional southward migration to sites with exposed vegetation. In the spring, individuals traveled up to $160 \mathrm{~km}$ over 18 days to their breeding ranges.

Implications: GRSG in Greater sage-grouse Management Zone I rely on very long, obligate annual migrations to reach critical seasonal habitats. GRSG migration and connectivity will benefit from conserving large, intact landscapes of native vegetation on both public and private land.

Topics: agricultural conversion, behavior or demographics, broad-scale habitat characteristics, habitat selection, new geospatial data, weather and climate 


\section{O'Donnell, M.S., Aldridge, C.L., Doherty, K.E., and Fedy, B.C., 2015, Wyoming greater sage- grouse habitat prioritization-A collection of multi-scale seasonal models and geographic information systems land management tools: U.S. Geological Survey Data Series 891, 28}

p.

DOI: https://doi.org/10.3133/ds891

Background: A high rate of landscape change in Wyoming could adversely affect GRSG habitat. As a result, an understanding of habitat selection requirements is important for effective land management. Resource managers in this area need information on the spatial arrangement and quality of important GRSG habitats to balance conservation efforts and resource use.

Objectives: This report was produced to describe and document models used in a previously published study and discuss how resource managers can use the information to better manage GRSG habitat in Wyoming.

Methods: The authors described model inputs, data products, and selection of products for different management applications. Additionally, they provided geographic information system (GIS) data and software tools to help resource managers quantify habitat and assess habitat needs for a specific area.

Location: Wyoming; MZ I, MZ II

Findings: The report provides background on GRSG seasonal habitats; the multiscaled, seasonal (nesting, late brood-rearing, and winter) habitat suitability models used in the previously published study; and data inputs to those models. The report describes the seasonal habitat model inputs and outputs and provides guidance for appropriate uses of the outputs. The report also includes example basic and advanced applications of the data and describes two software tools that can help resource managers (1) summarize GRSG seasonal habitats in a user-defined area using the model outputs and (2) assess new local habitats in a user-defined area using new GRSG observations together with specific habitat model outputs (for example, region, scale, season, or combined seasons).

Implications: This report will assist resource managers in conservation and land use planning efforts by providing seasonal habitat maps and tools for evaluating and creating new data pertaining to GRSG habitat and management in Wyoming.

Topics: broad-scale habitat characteristics, habitat selection, new geospatial data 
*2019 Update* O'Donnell, M.S., Edmunds, D.R., Aldridge, C.L., Heinrichs, J.A., Coates, P.S., Prochazka, B.G., and Hanser, S.E., 2019, Designing multi-scale hierarchical monitoring frameworks for wildlife to support management: a sage-grouse case study: Ecosphere, v. 10, no. 9, p. 1-34.

DOI: https://doi.org/10.1002/ecs2.2872

Background: GRSG populations may be affected by processes occurring at multiple spatial scales. However, population demographic data are seldom analyzed in a hierarchical, or multiscale, manner. This can obfuscate our understanding of population trends and factors leading to observed population changes.

Objectives: The authors' goal was to develop an approach to hierarchically group, or cluster, populations into biologically meaningful, nested units for monitoring and analysis.

Methods: A graph-based clustering algorithm was used, along with input data on GRSG habitat selection, movement data, and researcher-defined constraint-based rules, to group leks into increasingly finer scale units, or cluster-levels. This method was employed in Nevada and Wyoming but could be used range-wide.

Location: Nevada, Wyoming; MZ I, MZ II, MZ III, MZ IV, MZ V

Findings: The authors found that their clustering approach worked well in Nevada when compared against an independent dataset of GRSG movements. The finest-scale lek cluster developed by the algorithm captured about 90 percent of GRSG movements, while the mid-level lek cluster scheme captured around 98 percent of movements. Model performance was not evaluated in Wyoming using movement data.

Implications: The ability to cluster GRSG leks into nested, biologically meaningful lek clusters will aid researchers and managers in producing population trend estimates at different spatial scales and help them determine drivers of trends across scales. This information will be important for developing effective management actions.

Topics: behavior or demographics, broad-scale habitat characteristics, effect distances or spatial scale, habitat selection, new geospatial data, population estimates or targets, site-scale habitat characteristics, survival 
*2019 Update* Oh, K.P., Aldridge, C.L., Forbey, J.S., Dadabay, C.Y., and Oyler-McCance, S.J., 2019, Conservation genomics in the sagebrush sea: Population divergence, demographic history, and local adaptation in sage-grouse (Centrocercus spp.): Genome Biology and Evolution, v. 11, no. 7, p. 2023-2034.

DOI: https://doi.org/10.1093/gbe/evz112

Background: Different GRSG populations may possess adaptations for consuming local varieties of sagebrush, a plant that is not digestible for most vertebrates. Identifying these localized genetic variations and how they arose is key for conservation of GRSG and Gunnison sage-grouse.

Objectives: The authors sought to: 1) sequence a reference genome for GRSG and Gunnison sage-grouse, and 2) evaluate genetic variation between populations and species.

Methods: DNA was extracted and sequenced for 90 GRSG and 16 Gunnison sage-grouse individuals from across the species' ranges. The authors then analyzed genetic material within and between populations and species. Genes potentially specific to sagebrush digestion were evaluated and compared using digestive enzymes from GRSG and domesticated chickens, a nonsagebrush obligate relative. Genetic material was also used to model historical GRSG populations.

Location: range-wide; MZ I, MZ II, MZ III, MZ IV, MZ V, MZ VI, MZ VII

Findings: The authors identified several GRSG genes that may support sagebrush digestion, which was corroborated by enzyme analysis. They also found adaptive variation in these genes among populations, possibly indicating specialization to local sagebrush varieties. GRSG in Washington were found to have the greatest genetic divergence from other populations, possibly due to natural barriers to dispersal such as conifer forests.

Implications: The Washington population's genetic dissimilarity potentially makes it important as a "reservoir" for improving genetic diversity of other populations via translocation. The authors suggest that special protections for this population may therefore be warranted. However, possible adaptation to local sagebrush varieties may complicate translocation of individuals between populations.

Topics: genetics, population estimates or targets, translocation 
*2019 Update* O'Neil, S.T., Coates, P.S., Brussee, B.E., Jackson, P.J., Howe, K.B., Moser, A.M., Foster, L.J., and Delehanty, D.J., 2018, Broad-scale occurrence of a subsidized avian predator-reducing impacts of ravens on sage-grouse and other sensitive prey: Journal of Applied Ecology, v. 55, no. 6, p. 2641-2652.

DOI: https://doi.org/10.1111/1365-2664.13249

Background: Human-caused changes in food and habitat availability have effectively subsidized the expansion of generalist predators like the common raven. This has led to increased predation of GRSG nests. However, the effects of human and environmental factors on raven populations at broad scales is not well understood.

Objectives: The authors sought to: 1) quantify raven occurrence across broad scales in sagebrush ecosystems, and 2) evaluate the effects of human versus natural factors that may influence raven expansion.

Methods: From 2007 to 2016, the authors surveyed for raven occurrence at 42 sites in sagebrush ecosystems. They modeled the probability of raven occurrence, comparing natural features and anthropogenic structures, including roads, transmission lines, and cropland.

Location: California, Idaho, Nevada, Oregon; MZ III, MZ IV, MZ V

Findings: Across broad scales, probability of raven occurrence in sagebrush was found to be much higher than previously thought. Occurrence was strongly associated with anthropogenic features like roads, roadside rest stops, agriculture, and transmission lines. However, big sagebrush cover was associated with decreased raven occurrence. Using these results, the authors created an anthropogenic influence index, which identified where raven occurrence may be influenced by human factors.

Implications: The authors proposed that their anthropogenic influence index can be used to identify priority areas where ravens are more likely to affect GRSG. It can also be used to target locations where management of anthropogenic features can help reduce raven expansion. Finally, they suggested that their methods can be applied to the management of other generalist predators.

Topics: agricultural conversion, broad-scale habitat characteristics, ex-urban development, infrastructure (roads, pipelines, powerlines, cell towers), new geospatial data, predators or predator control 


\section{Orning, E.K., and Young, J.K., 2016, Impacts of coyote removal on space use by greater sage-grouse: Human-Wildlife Interactions, v. 10, no. 2, p. 144-156.}

DOI: https://doi.org/10.26077/6v8r-q289

Background: To reduce declines in GRSG populations, some resource managers have employed predator control measures, such as coyote removal, in GRSG habitats. However, removal of predators like coyotes inherently results in increased human activity in these areas. Unintended effects on GRSG space use and movement because of increased human activity associated with predator removal are poorly understood.

Objectives: Study objectives were to examine the influence of three levels of coyote removal effort (no removal, targeted removal, and nontargeted removal) on GRSG home range size, movement, migration timing, and distance traveled.

Methods: The authors used GPS transmitters to track 59 GRSG hens from three lek complexes in areas of Wyoming with three levels of coyote removal effort. Targeted removal consisted of year-round coyote removal to reduce livestock depredation and agricultural damage plus additional removal efforts in GRSG nesting habitat in the spring. Nontargeted removal consisted of removal to benefit mule deer fawn production only. The authors then quantified GRSG movement rates and home range sizes for hens in each treatment type.

Location: northern Wyoming; MZ II

Findings: The authors found that GRSG hens had smaller home ranges, higher movement rates, greater distances traveled, and more interseasonal movements in areas of higher predator removal effort.

Implications: The study design did not allow for differentiation between GRSG effects associated with reduced predator densities compared to increased human activity associated with predator removal efforts. The authors were only able to look at the combination of the two aspects represented by the three treatment types examined. The study was also limited by small sample sizes and a short duration. The authors suggest that management actions that result in increased human activity in GRSG habitats can have unintended, and potentially negative, consequences on GRSG behavior and space use. The potential benefits of predator removal actions for GRSG population growth should be weighed against unintended costs associated with the increased disturbances required to carry them out.

Topics: behavior or demographics, human dimensions or economics, predators or predator control 


\section{Orning, E.K., and Young, J.K., 2017, Coyote removal-Can the short-term application of a controversial management tool improve female greater sage-grouse survival or nest success?: Wildlife Biology, 8 p.}

DOI: https://doi.org/10.26077/6v8r-q289

Background: Predator control efforts have a long history, but their effectiveness for protecting bird populations is uncertain. Predation has important effects on GRSG nest success in some systems, but landscape factors and indirect effects of predator control complicate our understanding of the relation between predator control efforts and GRSG populations.

Objectives: Study objectives were to identify (1) which predator species were affecting GRSG nesting success and survival and (2) whether coyote removal increased GRSG nest success or survival.

Methods: The experimental study addressed effects of predator removal on female GRSG and their nests at three lek complexes from 2011 to 2012. The study included a control site with no coyote removal, a nontargeted coyote removal site, and a third site with more intensive coyote removal targeted in GRSG nesting habitat. Pretreatment data were available for the intensive targeted treatment site and the no removal control site. The authors collected radio telemetry data from 69 female GRSG from seven leks or lek complexes in the spring to monitor survival and nest success. The authors also were able to collect data from trail cameras mounted at 21 nest sites to determine nest fate.

Location: northern Wyoming; MZ II

Findings: Coyotes and raptors were the most common predators of female GRSG before and after treatment, respectively. There was no measurable difference in female GRSG survival among treatments. Coyotes were also the most commonly observed nest predator, but an effect of predator removal treatment on GRSG nest success was not supported.

Implications: The authors noted the small sample sizes and short duration of their study and that GRSG vital rates can vary substantially between years. Predation of GRSG females and nests did shift from coyotes dominating before treatment to a more equal distribution of predation between coyotes and ravens (nest predation) and raptors (female predation) after treatment. Predation was deemed unlikely to be the main driver of female survival in the study area.

Topics: behavior or demographics, predators or predator control, survival 


\section{Oyler-McCance, S.J., Cornman, R.S., Jones, K.L., and Fike, J.A., 2015, Genomic single- nucleotide polymorphisms confirm that Gunnison and greater sage-grouse are genetically well differentiated and that the Bi-State population is distinct: The Condor, v. 117, no. 2, p. 217-227.}

DOI: https://doi.org/10.1650/CONDOR-14-174.1

Background: Managing GRSG and defining conservation unit boundaries require an understanding of which populations belong to the species and the genetic variation that exists across its range. Based on past evidence, GRSG has been recognized as distinct from the Gunnison sage-grouse, but this taxonomic split could benefit from further genetic support, particularly because the Bi-State population exhibits high divergence from GRSG at neutral genetic markers. New genomic methods make it possible to assess both neutral and adaptive genetic variation, which can be used to better quantify the level of genetic differentiation between GRSG, Gunnison sage-grouse, and the Bi-State GRSG population.

Objectives: The authors sought to use a new genomic technique to examine relative levels of genomic divergence between GRSG, the Bi-State GRSG population, and Gunnison sage-grouse.

Methods: Tissue samples from previous studies were used to document genetic diversity of GRSG in the southern portion of its range and the entire ranges of the Bi-State and Gunnison sage-grouse populations. Single-nucleotide polymorphisms (SNPs) were identified and used to quantify genetic diversity and differentiation among individuals from the three groups.

Location: California, Colorado, Nevada, Utah, Wyoming; MZ I, MZ II, MZ III, MZ IV, MZ V, MZ VII

Findings: GRSG and Gunnison sage-grouse were confirmed to be highly divergent, with GRSG having greater within-group diversity. Individuals from the Bi-State population were significantly, but more weakly, differentiated from GRSG, indicating low gene flow between GRSG and the Bi-State population. Individuals within the GRSG population were not differentiated from one another.

Implications: The study confirmed that GRSG and Gunnison sage-grouse are genetically distinct, supporting the species delineation, and found that individuals from the Bi-State region constitute a unique population of GRSG. This information will guide conservation efforts related to these three distinct groups.

Topics: genetics 


\section{Oyler-McCance, S.J., Cornman, R.S., Jones, K.L., and Fike, J.A., 2015, Z chromosome divergence, polymorphism and relative effective population size in a genus of lekking birds: Heredity, v. 115 , no. 5, p. 452-459.}

DOI: https://doi.org/10.1038/hdy.2015.46

Background: Sex chromosomes ( $\mathrm{X}$ in most mammals, $\mathrm{Z}$ in birds) are thought to be important in the process of speciation, partly because there is no second allele to mask the effects of mutations (as is the case for autosomes) and because sex chromosomes frequently have low diversity. The greater divergence between GRSG and Gunnison sage-grouse, relative to the lower divergence between GRSG and the Bi-State population of GRSG, coupled with the lekking mating system of all three groups, provides a unique opportunity to study how sex chromosome diversity is influenced by the disproportionate reproductive success of a small number of males.

Objectives: The authors sought (1) to quantify divergence between GRSG and Gunnison sagegrouse and (2) to examine relatively recent Z-chromosome evolution through a comparison of autosomal and Z-chromosome diversity and divergence across and within the two species.

Methods: Random genomic single nucleotide polymorphisms in DNA samples from 10 individuals per taxa were identified as being autosomal or Z-linked. Genotypes for about 3,000 loci were assigned and used to measure diversity and divergence by combinations of gender, chromosome-type, and taxa. Metrics of diversity, differentiation, and effective population size were calculated.

Location: California, Colorado, Nevada, Utah, Wyoming; MZ I, MZ II, MZ III, MZ IV, MZ V, MZ VII

Findings: Z-chromosomes evolve faster and have a smaller effective population size than autosomes for both grouse species, a pattern known as fast-Z.

Implications: The fast- $Z$ pattern observed is likely pronounced in these grouse species because of their nonrandom, nonmonogamous mating system. The pattern was especially pronounced in Gunnison sage-grouse, potentially because of strong selection or genetic drift resulting from a population bottleneck or founder event.

Topics: genetics 


\section{Palmquist, K.A., Schlaepfer, D.R., Bradford, J.B., and Lauenroth, W.K., 2016, Mid-latitude shrub steppe plant communities-Climate change consequences for soil water resources: Ecology, v. 97, no. 9, p. 2342-2354.}

DOI: https://doi.org/10.1002/ecy.1457

Background: Dryland ecosystems such as sagebrush steppe are expected to experience substantial climate changes over the next century. It is unclear how changes in temperature and precipitation regimes will affect the ecohydrology of the sagebrush steppe plant communities on which GRSG depend.

Objectives: The authors' objectives were to determine (1) the amount of variability that exists among 10 future climate projections and the ecohydrology driven by those future climate regimes for current sagebrush ecosystems over the next century and (2) how future climate conditions might affect important aspects of big sagebrush ecohydrology.

Methods: Climate predictions from 10 global circulation models were applied to 898 sites in sagebrush ecosystems for the time periods 1980-2010, 2030-2060, and 2070-2100. The authors used a process-based water balance model to model daily water balance at each site and time period, taking into account site-specific vegetation and soil properties.

Location: Arizona, California, Colorado, Idaho, Montana, Nevada, New Mexico, Oregon, Utah, Washington, Wyoming; MZ I, MZ II, MZ III, MZ IV, MZ V, MZ VI, MZ VII

Findings: There was high agreement among global circulation models on increases in temperature but less agreement on precipitation changes. Precipitation and soil moisture are expected to increase in the winter and spring in the future, but warmer temperatures will increase evapotranspiration in the late spring and summer, resulting in less soil water available for plants than is currently observed.

Implications: Longer, drier summers will likely have a negative effect on sagebrush regeneration and seedling survival and may result in changes to plant functional group composition within current GRSG habitats.

Topics: broad-scale habitat characteristics, new geospatial data, weather and climate 


\section{Palmquist, K.A., Schlaepfer, D.R., Bradford, J.B., and Lauenroth, W.K., 2016, Spatial and ecological variation in dryland ecohydrological responses to climate change- Implications for management: Ecosphere, v. 7, no. 11, article e01590, 20 p.}

DOI: https://doi.org/10.1002/ecs2.1590

Background: Researchers expect substantial spatial variation in the ecohydrological response of plants to climate change. Understanding the spatial patterning of this response will be important for current and future adaptive management of GRSG habitats.

Objectives: The goal of this study was to predict how climate change-induced alterations to ecohydrology will differ across (1) current climate gradients, (2) three big sagebrush community types, and (3) different Sage-grouse Management Zones.

Methods: Climate predictions from 10 global circulation models for the representative concentration pathway (RCP) 8.5 by middle of the century were applied to 898 sites in sagebrush ecosystems. The authors used a process-based water balance model to model water availability and dry days at each site, taking into account site-specific vegetation and soil properties.

Location: range-wide; MZ I, MZ II, MZ III, MZ IV, MZ V, MZ VI, MZ VII

Findings: In general, soil water will increase in the spring and decrease in the summer under this future climate projection. High-elevation sites and the eastern and central portions of the GRSG range are expected to have the greatest increases in spring soil water, whereas decreases of up to 50 percent in summer soil water are expected at mid-elevation sites in the central and westcentral portion of the range. The number of dry days is expected to increase range-wide, but especially in the eastern and northern portions of the GRSG range.

Implications: Drier summer conditions in higher elevation areas could lead to increased suitability for big sagebrush, whereas mid to lower elevation sites could become less suitable for big sagebrush and consequently GRSG. This information could help prioritize areas for conservation of shrub steppe ecosystems into the future.

Topics: broad-scale habitat characteristics, new geospatial data, weather and climate 


\section{Peebles, L.W., and Conover, M.R., 2016, Effectiveness of the toxicant DRC-1339 in reducing populations of common ravens in Wyoming: Wildlife Society Bulletin, v. 40, no. 2, p. 281- 287.}

DOI: https://doi.org/10.1002/wsb.661

Background: Common ravens depredate GRSG nests, and raven populations have increased substantially in the western United States in the last hundred years. Resource managers use the toxicant DRC-1339 to reduce common raven populations, but the effectiveness of this treatment is poorly understood because of low detection probabilities of raven carcasses.

Objectives: The authors' objectives were to determine (1) the effectiveness of a raven population reduction program, (2) which raven mortality monitoring method was most effective, and (3) whether ravens avoid areas where DRC-1339 has been applied.

Methods: U.S. Department of Agriculture's Animal and Plant Health Inspection Service conducted a DRC-1339 poisoning regime consistent with commonly used protocols. The authors conducted raven counts and carcass searches during and after application of DRC-1339 to determine mortality. Radio-marked individuals were tracked at 3 landfills and 5 associated roost sites from 2013 to 2015 to assess survival of ravens at large.

Location: southwestern Wyoming; MZ II

Findings: Control efforts reduced raven populations by 7-34 percent per year, and nearly all of the raven carcasses detected had died of poisoning. However, these population reductions were countered the following year with high fecundity and immigration. Roost counts were the most accurate method for estimating mortality, and ravens did not avoid areas following poison application.

Implications: Results indicated that raven populations near GRSG nests can be reduced through DRC-1339 poisoning. However, populations quickly recovered to pretreatment levels, suggesting that annual treatment may be needed. The authors also suggested limiting anthropogenic sources of food for ravens and frequently removing roadkill.

Topics: infrastructure (roads, pipelines, powerlines, cell towers), predators or predator control 


\section{Peebles, L.W., Conover, M.R., and Dinkins, J.B., 2017, Adult sage-grouse numbers rise following raven removal or an increase in precipitation: Wildlife Society Bulletin, v. 41, no. 3, p. 471-478.}

DOI: https://doi.org/10.1002/wsb.788

Background: Ravens are significant predators of GRSG nests and chicks. Lethal removal of ravens has been conducted to benefit GRSG populations, but the effects of raven removal on avian populations have been mixed, and no studies to date have explored the effect of raven removal on GRSG population growth. Weather conditions may also influence GRSG recruitment; for example, weather can affect chick fitness and survival.

Objectives: Study objectives were (1) to evaluate the relation between changes in raven density and GRSG lek counts 1 year later and 2) to assess relations between weather conditions and GRSG lek counts.

Methods: The authors conducted 6,255 annual point counts of ravens from 2008 through 2014 (split between removal and nonremoval sites) and used GRSG lek count data from 12 sites (7 of which received raven removal) from 2008 through 2015. Seasonal temperature and precipitation variables were included in models to account for potential weather-related effects on lek counts.

Location: southwestern and south-central Wyoming; MZ II

Findings: Raven densities decreased by 51 percent in removal sites and increased by 41 percent in nonremoval sites over the course of the study. The best statistical model in the analysis indicated that change in raven density and minimum temperature during brood rearing were negatively associated with lek counts 1 year later and that precipitation during brood rearing was positively associated with the lagged lek counts.

Implications: Annual removal of ravens was effective at reducing raven densities at a landscape scale over a multiyear period. Removal of ravens was associated with larger numbers of GRSG the following year, as was cool, wet weather. The increase in GRSG abundance may have been due to decreased nest predation, increased habitat availability, or increased forb and insect abundance. The authors suggest that raven removal may be most beneficial where subsidized raven densities are high and GRSG populations are small.

Topics: behavior or demographics, predators or predator control, weather and climate 


\section{Pennington, V.E., Palmquist, K.A., Bradford, J.B., and Lauenroth, W.K., 2017, Climate and soil texture influence patterns of forb species richness and composition in big sagebrush plant communities across their spatial extent in the western US: Plant Ecology, v. 218, no. 8, p. 957-970.}

DOI: https://doi.org/10.1007/s11258-017-0743-9

Background: Forbs are an important component of sagebrush community diversity, contributing to community resilience, primary productivity, and wildlife habitat values. Forbs are also an important component of GRSG diets, especially during brood-rearing.

Objectives: The objectives of this research on big sagebrush forb communities were to identify (1) spatial patterns of forb diversity, (2) environmental determinants of forb diversity, (3) spatial patterns in forb composition within and among sites, and (4) environmental variables associated with composition.

Methods: The authors sampled soil and the richness and composition of forb species at 15 sites in relatively intact sagebrush stands in five Sage-grouse Management Zones.

Location: Colorado, Idaho, Montana, Nevada, Oregon, Utah, Wyoming; MZ I, MZ II, MZ III, MZ IV, MZ V

Findings: Soil texture was the primary driver of forb species richness, whereas forb species composition was most strongly related to climate. Plot-level forb species richness was not different across Management Zones. Most species were found at only 1 or 2 sites, and the 7 most common species were all native. Species in the genera Astragalus, Erigeron, and Phlox were found at all sites. Aspect and precipitation were strong predictors of species-level composition, and aspect, elevation, precipitation, and percent silt were strong predictors of genus-level compositional differences between sites.

Implications: Local site factors were more influential than large-scale factors on species richness, but the inverse was found for species composition. The authors concluded that water availability, mediated by soil texture and climate, is an important driver of forb species composition and richness. Climate changes that alter soil-water availability could affect forbs and animal species, such as GRSG, that rely on them.

Topics: site-scale habitat characteristics, weather and climate 


\section{Pennington, V.E., Schlaepfer, D.R., Beck, J.L., Bradford, J.B., Palmquist, K.A., and Lauenroth, W.K., 2016, Sagebrush, greater sage-grouse, and the occurrence and importance of forbs: Western North American Naturalist, v. 76, no. 3, p. 298-312.}

DOI: https://doi.org/10.3398/064.076.0307

Background: GRSG use forb species for food and cover, but native forbs in sagebrush habitats could be adversely affected by rangeland management practices and climate changes that result in changes in soil-water availability. Further, there is a need to synthesize the state of knowledge regarding GRSG and forbs in the sagebrush ecosystem.

Objectives: The goals of this literature review were to present information on (1) forbs and their importance as food and habitat for GRSG, (2) effects of land management on forbs, (3) forb response to temperature and precipitation, and (4) research needs related to forbs in sagebrush ecosystems.

Methods: The authors conducted a literature search in November 2013 using Web of Science and Google Scholar for journals and government reports; they synthesized information from 68 studies that met their criteria for inclusion.

Location: The geographic range of the literature search is unclear, but it is likely broad.

Findings: Forbs, especially those in the Asteraceae family, constitute an important part of GRSG spring and summer diets. Forbs also provide cover for GRSG at lekking, nesting, and broodrearing sites. Effects of grazing, fire, and chemical or mechanical treatment on native forbs are largely context specific. Grazing may negatively affect forbs, but experimental evidence is limited. Forbs respond to climate and weather gradients in a species-specific manner. The study also identified three primary knowledge gaps - forbs are typically only reported to genus or functional type, and there is limited information about both forbs near leks and the relation of forbs to temperature and precipitation.

Implications: The authors concluded that wide agreement exists among biologists regarding the importance of forbs for GRGS, but information on forb distribution and relations to climate is limited. Habitat descriptions that lump all herbaceous species (grasses and forbs), or simply recognize that GRSG eat forbs, do not provide sufficient information for management of GRSGpreferred forbs. Different forb species respond differently to grazing, invaders, chemical treatments, and climate, but details for most species were lacking. Filling this knowledge gap could facilitate forecasting climate change effects on forbs in sagebrush ecosystems.

Topics: broad-scale habitat characteristics, site-scale habitat characteristics 


\section{*2019 Update* Perry, A.C., Krakauer, A.H., McElreath, R., Harris, D.J., and Patricelli, G.L., 2019, Hidden Markov models reveal tactical adjustment of temporally clustered courtship displays in response to the behaviors of a robotic female: The American Naturalist, v. 194, no. 1, p. 1-16. \\ DOI: https://doi.org/10.1086/703518}

Background: Male GRSG adjust their courtship displays in order to increase their attractiveness to females but cannot indefinitely perform at their peak. Males can adjust either the number of consecutive "strut" displays in each of their display bouts, or the timing of the displays within a display bout. How these changes in display structure over time and in different social contexts influence mating success is not well understood but may be important in characterizing fitness and costs associated with lek displays.

Objectives: The authors sought to determine: (1) how male mating success is influenced by the number of consecutive "strut" displays in their display bouts versus the rate of consecutive displays within a bout, and (2) how males vary their display behavior in response to different behavioral cues from females.

Methods: The authors recorded and identified 51 GRSG males during courtship displays at three leks during the 2012 breeding season. They also elicited male displays using a robotic female, which simulated interested and uninterested female behavior. Changes in courtship display structure, responses to social cues, and mating success were then modeled.

\section{Location: Wyoming; MZ II}

Findings: Successfully-mating males had longer display bouts regardless of interest from females, while unsuccessful males varied their bout length according to female interest. When no females were present, longer display bouts were negatively associated with male mating success.

Implications: Bout length, regardless of female interest, is a better predictor of male mating success than display rate. Such male display behavior may indicate greater stamina, and therefore higher fitness.

Topics: behavior or demographics 


\section{Peters, D.T., and Ward, L., 2017, Greater sage-grouse in Montana-Mapping archetype viewpoints across stakeholder groups using $Q$ Methodology: Wildlife Society Bulletin, v. 41 , no. 1, p. 34-41.}

DOI: https://doi.org/10.1002/wsb.727

Background: Diverse stakeholders can have strongly diverging viewpoints on causes of and solutions to declining GRSG populations. Implementing GRSG habitat management plans to prevent the species from being listed under the Endangered Species Act of 1973 depends in large part on cooperation among these groups.

Objectives: Study objectives were to identify (1) the different stakeholder viewpoints regarding GRSG management, (2) the issues differentiating the main points of view among different stakeholders, and (3) the issues which may represent areas of common ground among stakeholders.

Methods: The authors assessed stakeholder viewpoints on GRSG management in Montana from 2010 to 2014 by using semi-structured interviews and ranking, factor, and correlation analyses. Forty-eight government natural resource managers, oil and gas industry employees, members of nongovernmental organizations, ranchers, Native Americans, and other concerned citizens - all with professional ties to GRSG core habitat areas - were surveyed regarding potential causes of GRSG decline and potential management actions to address that decline.

Location: east-central Montana; MZ I

Findings: Three viewpoints on potential GRSG management strategies were apparent: limiting development, limiting regulation, and focusing on local governance. Assessment findings indicated that starting points for agreement include concern over sod-busting and the economic effects of listing GRSG as an endangered species, whereas views on climate change and predators were sources of contention.

Implications: Making management decisions in a participatory context requires some level of consensus, which can be difficult to achieve when stakeholders have strongly diverging opinions on important aspects of that management. Stakeholders in Montana disagreed about the role of science in decision making and the magnitude of government intervention into local and private property concerns. Areas of consensus identified here represent a potential way forward in developing GRSG management policies that address the perceived lack of consideration of local input. Individuals who can foster meaningful dialog among stakeholders with divergent viewpoints are an important next step in a collaborative policy and implementation process.

Topics: human dimensions or economics, predators or predator control, weather and climate 


\section{Petersen, S.L., Nicholes, B.K., Frey, S.N., Heaton, K.M., and Eggett, D.L., 2016, Response of greater sage-grouse to surface coal mining and habitat conservation in association with the mine: Human-Wildlife Interactions, v. 10, no. 2, p. 205-216.}

DOI: https://doi.org/10.26077/2ra2-rt34

Background: Habitat alteration and loss due to energy extraction and mining have been identified by the U.S. Fish and Wildlife Service as a range-wide threat to GRSG persistence, as studies have demonstrated GRSG population declines in proximity to mining activity. In an attempt to mitigate habitat alterations at a mine in southern Utah in the Alton/Sink Valley area, habitat restoration and predator control treatments were conducted. Because GRSG habitat in this area was highly modified and fragmented prior to mining, the authors speculated that habitat management and offsite mitigation could benefit the population and balance any effects of habitat loss resulting from mining activities.

Objectives: The objectives of the study were (1) to quantify changes in male lek attendance due to mining, associated mitigation activities, and predator control and (2) to determine whether GRSG densities were affected by proximity to mining activities.

Methods: The authors compared male lek counts from before mining (1991-2010) to values obtained during mining and mitigation (2011-2016) at a mine in southern Utah. They also recorded GRSG densities and distances from mining operations along transects. Mitigation activities included habitat restoration, pinyon-juniper removal, predator control, and pre-mining acclimation to human activities. No comparisons were made to control GRSG populations.

Location: southwestern Utah; MZ III

Findings: There was no difference in mean male lek counts between the years prior to mining and mitigation and the 6 years after mining began. There were no differences in GRSG density with increasing distance from mining activities. Observed birds were an average of 1.2 kilometers $(\mathrm{km})$ from the center of the mine and $0.5 \mathrm{~km}$ from the nearest edge of the mine.

Implications: The authors conclude that surface coal mining and associated mitigation did not cause a decline in the existing GRSG population at the Alton/Sink Valley area of southwest Utah. Habitat fidelity and acclimation to a long history of anthropogenic activities may have affected GRSG behavior in this region. GRSG at this location did not avoid mining activities as other GRSG populations have been observed to do elsewhere in the range.

Topics: behavior or demographics, conifer expansion, effect distances or spatial scale, habitat restoration or reclamation, mining, predators or predator control, site-scale habitat characteristics 


\section{*2019 Update* Pidot, J.R., 2018, Public-private conservation agreements and the greater sage-grouse: Public Land \& Resource Law Review, v. 39, no. 5, p. 165-205.}

DOI: https://scholarship.law.umt.edu/plrlr/vol39/iss1/5/

Background: Partnerships that involve federal, state, and private entities can improve GRSG conservation and decrease economic and regulatory uncertainty. The ingredients for successful public-private conservation agreements therefore warrant study in order to understand how collaborative GRSG conservation can be effective.

Objectives: The author presented a case study of two public-private GRSG conservation agreements in order to identify key ingredients to their success.

Methods: The author discussed the background of the Endangered Species Act and the context of recent federal framework for GRSG conservation. The author then described the differences and similarities of the agreements between the BLM and two private companies: Barrick Gold of North America and Newmont Mining Corporation.

Location: California, Nevada; MZ III, MZ IV, MZ V

Findings: Both companies operate a variety of long-term projects on public lands and voluntarily collaborated with the BLM to use mitigation credits in order to avoid the potential listing of GRSG under the Endangered Species Act. The BLM reviewed and approved mitigation activities and retained a large degree of discretion. This allowed the BLM to be more flexible in administering the agreements.

Implications: Successful public-private collaboration increases ecological, economic, and regulatory certainty. This was achieved via voluntary conservation actions aimed at preventing the listing of GRSG. Similar agreements involving smaller private enterprises may place more importance on the sale or transfer of mitigation credits.

Topics: human dimensions or economics, mining 
*2019 Update* Pratt, A.C., and Beck, J.L., 2019, Greater sage-grouse response to bentonite mining: The Journal of Wildlife Management, v. 84, no. 4, p. 866-879.

DOI: https://doi.org/10.1002/jwmg.21644

Background: Bentonite mining may contribute to significant loss or alteration of GRSG habitat. However, the effects of this kind of open-pit mining on GRSG populations are not well understood and may differ from effects of other types of resource extraction.

Objectives: The authors sought to assess GRSG habitat associations and mortality risk related to bentonite mining.

Methods: From 2011 to 2015, the authors captured a total of 321 females in the Bighorn Basin and fit them with VHF or GPS transmitters. Location data was used to determine nest success. The authors mapped active and reclaimed bentonite mines, then modeled GRSG habitat associations and mortality risk in comparison with mining disturbance.

Location: Montana, Wyoming; MZ II

Findings: The probability of females selecting nest sites, brood locations, breeding season habitat, or winter habitat decreased significantly in areas with active or reclaimed bentonite mines. The risk of nest failure did not appear to be affected by mining, and the risk of brood failure was inconclusive. However, females exposed to active mining were 19 times more likely to die compared to unexposed females, which is likely to affect brood success. These effects are likely caused by noise, human presence, and predation.

Implications: In general, the adverse effects of bentonite mining on GRSG appear to be consistent with those of energy development. A greater proportion of the Bighorn Basin GRSG population is affected by mining during the winter season than at other times of year. Therefore, prioritization of winter habitat may be a key management strategy. Further, reclaimed mines remain unsuitable for GRSG due to slow regeneration of sagebrush cover, so intense promotion of sagebrush regeneration is important for restoring GRSG habitat.

Topics: behavior or demographics, habitat restoration or reclamation, habitat selection, mining, site-scale habitat characteristics, survival 


\section{Pratt, A.C., Smith, K.T., and Beck, J.L., 2017, Environmental cues used by greater sage- grouse to initiate altitudinal migration: The Auk, v. 134, no. 3, p. 628-643.}

DOI: https://doi.org/10.1642/AUK-16-192.1

Background: Migration between seasonal habitats is a critical behavior for many GRSG populations that must move to take advantage of resources while also avoiding adverse conditions. However, there is currently little information available on several key aspects of GRSG migratory behavior.

Objectives: The authors' objectives were to determine (1) whether GRSG seasonal, altitudinal migrations were initiated by direct or indirect cues of changing resource quality, (2) whether migration timing was affected by the characteristics of individuals, and (3) whether migratory versus nonmigratory behavior of individuals within a population could be explained by exposure to contrasting environmental conditions.

Methods: The authors used GPS transmitters to track at least 84 GRSG at two sites. The authors determined whether individuals were migratory or nonmigratory and related the timing of 292 individual migration events to several potential predictor variables representing direct cues, indirect cues, and traits of individuals.

Location: south-central Montana, central Wyoming; MZ II

Findings: The authors found that GRSG used direct cues, such as temperature, to initiate migration between seasonal ranges. Traits of individuals, such as starting location, reproductive status, and habitat occupied, were also important predictors of migration timing. Further, migratory individuals were exposed to greater migration cues than nonmigratory individuals, likely because they occupy a larger altitudinal gradient encompassing warmer breeding ranges and cooler summer ranges.

Implications: The authors conclude that migratory behaviors of GRSG individuals are influenced by the landscape they occupy and by characteristics of the individual. Further, large environmental gradients may influence the proportion of migratory and nonmigratory individuals in a population.

Topics: behavior or demographics, habitat selection, weather and climate 
*2019 Update* Pratt, A.C., Smith, K.T., and Beck, J.L., 2019, Prioritizing seasonal habitats for comprehensive conservation of a partially migratory species: Global Ecology and Conservation, v. 17, e00594, p. 1-11.

DOI: https://doi.org/10.1016/j.gecco.2019.e00594

Background: Different GRSG populations can have varying degrees of migratory behavior. Although conservation of breeding habitat has been a priority for management, it is unclear how effective this is for migratory populations. Understanding how to prioritize habitat conservation strategies for migratory and non-migratory populations may be important for improving GRSG conservation overall.

Objectives: The authors sought to (1) quantify GRSG migratory behaviors, (2) determine the similarity of habitat throughout the year, and (3) evaluate which seasonal habitat should be prioritized for conservation.

Methods: Between 2012 and 2014, the authors captured a total of 133 female GRSG of the Bighorn Basin and Central Wyoming populations and fit them with GPS transmitters. Location data was used to compare the two populations, evaluate migratory behavior, and characterize habitat as breeding, summer, winter, or transitional. The authors then modeled seasonality of habitat selection probability and habitat similarity.

Location: Montana, Wyoming; MZ II

Findings: The Bighorn Basin GRSG population appeared to have a greater proportion of migratory individuals than the Central Wyoming population and used more dissimilar summer and winter habitats. However, breeding habitat was most similar to all other seasonal habitats for both populations. Differences in elevational gradients, land cover, and anthropogenic land uses like agriculture may influence the migratory behaviors observed among the two populations.

Implications: Conservation approaches like Wyoming's Core Areas Strategy that prioritize breeding habitat appear to be effective as a first step. However, various GRSG populations may partly require additional conservation of different seasonal habitats. Local information on behavior and habitat should be used to determine these specific habitat requirements and how to manage them.

Topics: behavior or demographics, broad-scale habitat characteristics, habitat selection 


\section{Prochazka, B.G., Coates, P.S., Ricca, M.A., Casazza, M.L., Gustafson, K.B., and Hull, J.M., 2017, Encounters with pinyon-juniper influence riskier movements in greater sage-grouse across the Great Basin: Rangeland Ecology and Management, v. 70, p. 39-49.}

DOI: https://doi.org/10.1016/j.rama.2016.07.004

Background: The expansion of pinyon and juniper trees into sagebrush communities has resulted in GRSG habitat loss and fragmentation, and conifer encroachment is a widely cited factor contributing to GRSG population declines. The effects of pinyon-juniper woodland habitat on the fine-scale movements of individual GRSG are poorly understood, as are the costs associated with altered movement behavior.

Objectives: The goals of this study were to determine (1) how the movement of GRSG individuals of different age classes was affected by encountering pinyon-juniper communities and (2) the costs, in terms of mortality risk, that are associated with movements near these communities.

Methods: The authors tracked 233 GRSG at 12 sites in the Great Basin from 2012 to 2015 . They used high-frequency GPS location data (282,954 locations) and high-resolution maps of conifer cover to conduct behavior change-point analysis of individuals.

Location: northeastern California, northern Nevada; MZ III, MZ IV, MZ V

Findings: Adult GRSG were more likely to encounter pinyon-juniper than were yearlings and juveniles. The authors also found that an increasing probability of pinyon-juniper encounters, combined with increasing travel speed near these habitats (from taking flight), resulted in a substantially increased risk of mortality, especially for juveniles and yearlings.

Implications: The authors conclude that GRSG are negatively affected by pinyon-juniper encroachment because this habitat type stimulates faster, high-risk movements, such as flight, which likely attract visual predators. Further, the study quantifies age-specific GRSG mortality risk when individuals move through landscapes containing pinyon-juniper stands.

Topics: behavior or demographics, broad-scale habitat characteristics, conifer expansion, habitat selection, new geospatial data, site-scale habitat characteristics, survival 
Pyke, D.A., Chambers, J.C., Pellant, M., Knick, S.T., Miller, R.F., Beck, J.L., Doescher, P.S., Schupp, E.W., Roundy, B.A., Brunson, M., and Mclver, J.D., 2015, Restoration handbook for sagebrush steppe ecosystems with emphasis on greater sage-grouse habitat-Part 1. Concepts for understanding and applying restoration: U.S. Geological Survey Circular $1416,44 \mathrm{p}$.

DOI: https://doi.org/10.3133/cir1416

Background: Currently, sagebrush communities occupy only one-half of their historic area. Many factors, including land-use change, invasion of nonnative plants, and fire, have contributed to this decline, which has resulted in less suitable habitat available for sagebrush-obligate species such as GRSG. Vast areas of these former sagebrush systems lack the resilience to return to their pre-disturbance state without assistance from restoration treatments.

Objectives: The goal of the first part of this three-part series is to provide background information on the sagebrush biome and on GRSG to introduce or refresh decision makers on important concepts necessary in making restoration decisions for GRSG habitat.

Methods: In Part 1 of this series, the authors review topics and concepts relevant to the restoration and management of sagebrush ecosystems and GRSG habitat, including landscape and restoration ecology, plant responses to disturbance, resistance and resilience concepts and tools, soils and ecological site information, and monitoring.

\section{Location: range-wide; MZ I, MZ II, MZ III, MZ IV, MZ V, MZ VI, MZ VII}

Findings: The report summarized current knowledge about the structure and composition of sagebrush ecosystems (including understory herbaceous plant communities), how they have changed over time, and how they respond to fire and defoliation. Resistance of sagebrush ecosystems to invasion by nonnative grasses and resilience to disturbances like fire was described, along with the soil moisture and soil temperature regime information that provides the foundation for quantifying both concepts in sagebrush ecosystems. The report also described how ecological site information can inform restoration efforts; passive and active restoration actions and methods; landscape ecology concepts of fragmentation, connectivity, hierarchical structuring, and landscape species; and the role of effectiveness monitoring in informing in sagebrush ecosystem restoration efforts.

Implications: This report will help resource managers make decisions about where and how to conduct restoration treatments in former sagebrush ecosystems for the benefit of sagebrushobligate species like GRSG.

Topics: broad-scale habitat characteristics, fire or fuel breaks, habitat restoration or reclamation, non-native invasive plants 
Pyke, D.A., Chambers, J.C., Pellant, M., Miller, R.F., Beck, J.L., Doescher, P.S., Roundy, B.A., Schupp, E.W., Knick, S.T., Brunson, M., and Mclver, J.D., 2017, Restoration handbook for sagebrush steppe ecosystems with emphasis on greater sage-grouse habitat-Part 3. Site level restoration decisions: U.S. Geological Survey Circular 1426, 62 p.

DOI: https://doi.org/10.3133/cir1426

Background: Many factors, including land-use change, invasion of nonnative plants, and fire, have contributed to a significant decline in the extent of sagebrush ecosystems. Restoration of sagebrush ecosystems can benefit livestock, wild horses, and wildlife species that inhabit these systems, including sagebrush-obligate species such as GRSG.

Objectives: The third part in the series provides land managers with progressive steps in the restoration process that they may follow to enhance restoration success at an individual site.

Methods: In Part 3 of this series, the authors discuss site-level restoration decisions, particularly selection of appropriate treatments for a given site. They provide a nine-step tool to help resource managers define objectives, describe site characteristics, select site-appropriate treatments, and conduct post-treatment management and monitoring.

Location: range-wide; MZ I, MZ II, MZ III, MZ IV, MZ V, MZ VI, MZ VII

Findings: The site-scale decision tool includes nine steps that begin with identifying restoration objectives followed by describing the ecological site characteristics, assessing current vegetation and land uses and past disturbances, considering potential effects of weather conditions on restoration success, deciding on restoration approaches and treatments, planning for postrestoration grazing management, planning for implementation and effectiveness monitoring, and using monitoring information to improve future restoration efforts.

Implications: This report and the tool it describes will help resource managers make decisions that should enhance their success in restoring sagebrush ecosystems and thus GRSG habitat at an individual site.

Topics: habitat restoration or reclamation, site-scale habitat characteristics 


\section{Pyke, D.A., Knick, S.T., Chambers, J.C., Pellant, M., Miller, R.F., Beck, J.L., Doescher, P.S., Schupp, E.W., Roundy, B.A., Brunson, M., and Mclver, J.D., 2015, Restoration handbook for sagebrush steppe ecosystems with emphasis on greater sage-grouse habitat-Part 2. Landscape level restoration decisions: U.S. Geological Survey Circular 1418, 21 p.}

DOI: https://doi.org/10.3133/cir1418

Background: Vast areas of former sagebrush habitats lack the resilience to return to their predisturbance state without assistance from restoration treatments. Because resources are not available to restore all degraded areas, resource managers could prioritize restoration investments to maximize benefits by considering the landscape context of restoration project locations. For example, projects that improve connectivity between intact sagebrush habitats might be a high priority.

Objectives: The objective of the second part of this series is to provide resource managers with information necessary to make decisions at the landscape scale that can enhance the value of restoration efforts for sagebrush-obligate species.

Methods: In Part 2 of this series, the authors discuss a landscape restoration decision tool that can help identify landscape restoration objectives, priority landscapes for treatment, and priority sites within landscapes.

Location: range-wide; MZ I, MZ II, MZ III, MZ IV, MZ V, MZ VI, MZ VII

Findings: The authors presented a landscape restoration decision tool in five sections that should be used in sequence. Section 1 helps managers decide if they should be considering landscapelevel restoration. Section 2 helps managers identify landscape restoration objectives. Section 3 provides a process for prioritizing both landscapes and sites within landscapes for restoration action. Section 4 walks the manager through using the concepts of resilience and resistance, and associated information, to help prioritize landscapes for treatment. Section 5 outlines elements in a landscape monitoring effort.

Implications: This report and the decision tool that it describes will help resource managers make decisions for prioritizing landscapes for restoration work. Once priority landscapes are determined, managers can move to selecting sites for restoration and use Part 3 in the handbook series.

Topics: broad-scale habitat characteristics, fire or fuel breaks, habitat restoration or reclamation, nonnative invasive plants 


\section{*2019 Update* Ramey, R.R., Thorley, J.L., and Ivey, A.S., 2018, Local and population-level responses of greater sage-grouse to oil and gas development and climatic variation in Wyoming: PEERJ, v. 2018, no. 6, p. e5417.}

DOI: https://doi.org/10.7717/peerj.5417

Background: The effects of energy development on GRSG at a local scale have been well documented. However, how those effects scale to a population level is not well understood. More precise knowledge of these dynamics is important for quantifying the effect of oil and gas development on GRSG populations.

Objectives: The authors sought to estimate local and population-scale GRSG responses to oil and gas development as well as regional climatic variation as indexed by the Pacific Decadal Oscillation (PDO), potentially the most important climatic process influencing the sagebrush biome.

Methods: Using lek count and location data from eight working groups over 32 years, 19852016, the authors modeled local- and population-level responses to oil and gas surface disturbance and regional climatic variation as indexed by the PDO, which is derived from largescale spatial patterns of sea surface temperature in the North Pacific Ocean.

Location: Wyoming; MZ I, MZ II

Findings: Modeling revealed that oil and gas development had a strong negative effect on localscale lek attendance within a $3.2 \mathrm{~km}$ radius around a well. Oil and gas development was a weak predictor of population-scale changes, but appeared consistent with local-scale responses. The PDO was found to be a strong predictor of long-term population density fluctuations at local and population scales.

Implications: Wildlife agencies may benefit from accounting for the effects of regional climatic variation on population fluctuations when managing GRSG populations. Further study is needed to refine population-scale responses of GRSG to oil and gas development, especially within the context of the effects of the PDO.

Topics: behavior or demographics, effect distances or spatial scale, energy development, weather and climate 
*2019 Update* Reeves, M.C., Manning, M.E., DiBenedetto, J.P., Palmquist, K.A., Lauenroth, W.K., Bradford, J.B., and Schlaepfer, D.R., 2018, Effects of climate change on rangeland vegetation in the northern rockies region [chapter 7]. In: Halofsky, J.E., Peterson, D.L., Dante-Wood, S.K., Hoang, L, Ho, J.J., Joyce, L.A., eds. Climate change vulnerability and adaptation in the Northern Rocky Mountains [Part 2]. Gen. Tech. Rep. RMRS-GTR-374. Fort Collins, CO: U.S. Department of Agriculture, Forest Service, Rocky Mountain Research Station, p. 275-316.

DOI: https://doi.org/10.1007/978-3-319-56928-4_6

Background: Rangelands in the Northern Rocky region provide habitat for GRSG populations. These rangelands have been altered by land-use change, invaded by nonnative plant species, and influenced by changing fire regimes. It is unclear how species and biotic communities in this region may be affected by projected climate changes.

Objectives: The authors' goal was to assess potential climate change effects on rangeland habitats in the Northern Rocky region.

Methods: The authors used the best available information, including published literature, workshop output, and expert opinion from authors and reviewers, to project the potential effects of climate change on communities in the Northern Rocky region.

Location: Idaho, Montana, Wyoming; MZ I, MZ II, MZ IV

Findings: Changes in climate regime are likely to influence the phenology of grasses, forbs, and shrubs. Past studies have suggested that increases in annual net primary productivity can be expected as well. Changes in climate are expected to alter invasions by nonnative plants in terms of their extent, abundance, and species composition. Changes in species distributions are likely to result from shifts in climate as well.

Implications: The authors suggest that climate changes are likely to result in fairly substantial changes in plant species composition and distribution within the Northern Rocky region, an area that supports GRSG populations. These changes, along with those derived from changing fire regimes, drought, invasive species, and on-going land-use change, will present challenges for resource managers. The authors suggest that adaptive management strategies will be important for meeting these conservation challenges.

Topics: broad-scale habitat characteristics, non-native invasive plants, weather and climate 


\section{Reinhardt, J.R., Naugle, D.E., Maestas, J.D., Allred, B., Evans, J., and Falkowski, M., 2017, Next-generation restoration for sage-grouse-A framework for visualizing local conifer cuts within a landscape context: Ecosphere, v. 8, no. 7, article e01888, 18 p.}

DOI: https://doi.org/10.1002/ecs2.1888

Background: Encroachment of pinyon and juniper trees into sagebrush ecosystems results in loss of habitat, habitat fragmentation, and negative demographic effects for GRSG. Removal of pinyon-juniper stands from areas formerly dominated by sagebrush is an ongoing and highpriority effort in many parts of the GRSG range.

Objectives: The authors' objective was to create a framework for prioritizing areas for conifer removal based on (1) enhancing existing GRSG habitat, (2) increasing connectivity between GRSG seasonal ranges, and (3) increasing connectivity among GRSG Priority Areas for Conservation.

Methods: The authors used Marxan optimization software to identify priority areas for conifer removal using geospatial data on conifer cover, sagebrush cover, mesic habitat, GRSG lek locations, GRSG habitat suitability, and landscape resistance to invasive plants and resilience to wildfire.

Location: southeastern Oregon; MZ IV, MZ V

Findings: The models identified areas that tended to have low conifer cover, high resistance and resilience, and high GRSG density as high-priority areas for conifer removal. They also found potential corridors, which could increase GRSG connectivity, when mesic habitat and areas outside of identified Priority Areas for Conservation were included. Potential corridors sometimes passed through areas of higher conifer cover.

Implications: The authors conclude that the optimization framework and models used in this study illustrate an approach, increasingly available to land managers, which can augment or complement standard expert-based approaches to planning and prioritization. Such approaches could reduce planning and implementation time for landscape-scale conifer removal treatments.

Topics: broad-scale habitat characteristics, conifer expansion, habitat restoration or reclamation, new geospatial data 
*2019 Update* Ricca, M.A, Coates, P.S., Gustafson, K.B., Brussee, B.E, Chambers, J.C., Espinosa, S.P., Gardner, S.C., Lisius, S., Ziegler, P., Delehanty, D.J., and Casazza, M.L., 2018, A conservation planning tool for greater sage-grouse using indices of species distribution, resilience, and resistance: Ecological Applications, v. 28, no. 4, p. 878-896.

DOI: https://doi.org/10.1002/eap.1690

Background: Habitat restoration treatments targeting GRSG can be costly and success is not guaranteed. Estimating how GRSG may respond to treatments, while accounting for the processes driving resilience to disturbance and resistance to invasive species, can assist managers in prioritizing treatment types and locations across a landscape of interest, and ultimately improve restoration outcomes for GRSG populations.

Objectives: The authors' goal was to describe a new, spatially explicit conservation planning tool (CPT) designed to help managers prioritize locations for conifer removal and post-wildfire restoration targeting GRSG habitat.

Methods: Potential benefits to GRSG are estimated, for different treatments conducted in specific locations, using a composite index based on GRSG resource selection functions, estimates of abundance, and spatial use information. This facilitates ranking of potential treatment/location alternatives based on ecological benefit to GRSG per dollar-unit cost. The authors present the results of a simulated conifer removal treatment and a post-wildfire restoration project as examples.

\section{Location: California, Nevada; MZ III, MZ V}

Findings: Simulated results showed that the CPT can assist in identifying the most cost-effective treatment alternative after accounting for likely GRSG behavioral and demographic responses to treatment. The CPT improves upon other conservation tools in that it derives estimates from more than a single index and explicitly considers both sage-grouse and sagebrush ecosystem responses to restoration.

Implications: The CPT could help resource managers evaluate potential costs and benefits of treatments in specific locations in order to facilitate restoration prioritization decisions across landscapes used by GRSG.

Topics: behavior or demographics, broad-scale habitat characteristics, conifer expansion, habitat restoration or reclamation, habitat selection, new geospatial data, non-native invasive plants, population estimates or targets, site-scale habitat characteristics, survival 


\section{Rice, M.B., Rossi, L.G., and Apa, A.D., 2016, Seasonal habitat use by greater sage-grouse (Centrocercus urophasianus) on a landscape with low density oil and gas development: PLoS ONE, v. 11, no. 10, article e0165399, 20 p.}

DOI: https://doi.org/10.1371/journal.pone.0165399

Background: Energy development, which can negatively affect GRSG populations, has increased within the GRSG range in recent decades and is occurring in areas that have some of the highest densities of GRSG. Resource managers in areas that have the potential for new or increased energy development may benefit from mapping GRSG seasonal habitat use prior to the commencement of such development.

Objectives: The objectives of the study were (1) to create a model of GRSG seasonal habitat prior to the onset of development and (2) to quantify effects of the current, low-level energy development on GRSG habitat use.

Methods: The authors used location data from 117 radio-marked GRSG hens from the North Park GRSG population that were tracked during breeding, summer, and winter seasons in 2010 and 2011. They combined these data with geospatial data on land cover, surface water, plant productivity, and mining infrastructure to model GRSG habitat use prior to the onset of development for each season at local and landscape scales.

Location: northwestern Colorado; MZ II

Findings: GRSG used large, relatively continuous sagebrush habitats during the winter and breeding seasons, whereas the summer habitat model indicated increased use of riparian margins. Adding variables representing energy development infrastructure did not increase model fit for winter or summer habitat models, but there was evidence that female GRSG avoided oil/gas roads during the breeding season.

Implications: The authors concluded that studies of behavior prior to development occurring, such as this one, can provide resource managers with information that can be valuable when trying to site development to minimize effects on GRSG and their habitat, managing GRSG populations, and quantifying potential effects of development on GRSG populations. Conflicting findings regarding the effect of roads on breeding habitat when evaluated at local and landscape scales indicated that the spatial scale of analysis can have important and sometimes contradictory effects on model results; these findings also suggested that energy development in North Park may not currently be at a level that is affecting GRSG populations significantly.

Topics: broad-scale habitat characteristics, effect distances or spatial scale, energy development, habitat selection, infrastructure (roads, pipelines, powerlines, cell towers), mining, new geospatial data, site-scale habitat characteristics 


\section{Row, J.R., and Fedy, B.C., 2017, Spatial and temporal variation in the range-wide cyclic dynamics of greater sage-grouse: Oecologia, v. 185, p. 687-698.}

DOI: https://doi.org/10.1007/s00442-017-3970-9

Background: The cyclical nature of GRSG populations makes detecting trends and identifying causal factors challenging. Many GRSG populations cycle over time, but cycles can change, and reduced cycling can destabilize populations. Understanding the cause(s) of cycling may be important for conservation. This research seeks to elucidate spatial and temporal patterns in trends and cycles for GRSG populations range-wide.

Objectives: The authors asked three questions: (1) are spatial patterns of GRSG population cycles consistent across their range, (2) is there a latitudinal trend in cyclical dynamics, and (3) is there a spatial pattern to synchrony among GRSG populations.

Methods: The authors used compiled lek data from 6,751 lek locations (1965-2015) across the GRSG range to assess spatial and temporal patterns in GRSG population trends. The authors used multiple modeling techniques and statistical analyses to assess trends and cycles in lek counts over time and to compare trends and cycles in different populations.

Location: range-wide; MZ I, MZ II, MZ III, MZ IV, MZ V, MZ VI, MZ VII

Findings: The cyclical dynamics of GRSG populations varied across the range and through time. Populations in the core range - the Great Basin and Wyoming Basin - exhibited the most consistency. Marginal populations (north and south of the core range) exhibited the greatest variability through time. Patterns in population cycles varied over time for both peripheral populations and core populations. The period of cycles for most populations decreased over time, suggesting that changes in demographics may be driving fundamental changes in GRSG population dynamics.

Implications: Influential drivers of population demographics, such as survival, reproductive rates, and dispersal, are not consistent across the GRSG range. Environmental pressures and population declines may also affect cycling, and these factors are also variable across the species' range. Shifts in population cycles and synchrony of cycles began in the mid-1990s, which may correspond to changes in dispersal and environmental conditions affecting GRSG at large geographic scales.

Topics: behavior or demographics, population estimates or targets 
*2019 Update* Row, J.R., Doherty, K.E., Cross, T.B., Schwartz, M.K., Oyler-McCance, S.J., Naugle, D.E., Knick, S.T., and Fedy, B.C., 2018, Quantifying functional connectivity: the role of breeding habitat, abundance, and landscape features on range-wide gene flow in sage-grouse: Evolutionary Applications, v. 11, no. 8, p. 1305-1321.

DOI: https://doi.org/10.1111/eva.12627

Background: Conservation of species like GRSG can be informed by identifying and mapping factors that facilitate or hinder connectivity and gene flow across the landscape.

Objectives: The goal of this study was to model functional connectivity across the range of GRSG using resistance surfaces and genetic data.

Methods: Microsatellite genotyping was conducted on individual GRSG from 1,392 leks in five different MZs. Nearby leks were clustered based on genetic similarity. Pairwise dissimilarity was calculated for resulting clusters. Landscape resistance between each pair of lek clusters was quantified via circuit theory. Binary resistance surfaces were derived from published models incorporating various landcover, topographic, and population variables. Separate models were fit for each MZ.

Location: range-wide; MZ I, MZ II, MZ III, MZ IV, MZ V, MZ VI, MZ VII

Findings: The authors found that for each MZ, different habitat variables best predicted genetic differentiation and that this differentiation was not related to GRSG abundance metrics in most MZs. The authors found evidence that GRSG move through undesirable habitat to reach breeding sites and that topographic roughness and steepness were important predictors of connectivity in all MZs. Sagebrush, tree, and agricultural landcover were also important in many MZs.

Implications: Information regarding which factors facilitate or hinder connectivity, as well as maps produced using this information, can help guide conservation and management decisions and prioritization of areas for movement corridors or restoration.

Topics: behavior or demographics, broad-scale habitat characteristics, effect distances or spatial scale, genetics, new geospatial data 


\section{Row, J.R., Knick, S.T., Oyler-McCance, S.J., Lougheed, S.C., and Fedy, B.C., 2017, Developing approaches for linear mixed modeling in landscape genetics through landscape-directed dispersal simulations: Ecology and Evolution, v. 7, no. 11, p. 3751- 3761.}

DOI: https://doi.org/10.1002/ece3.2825

Background: Dispersal affects population dynamics and can influence genetic diversity. A better understanding of how landscape features affect dispersal can inform management actions designed to help sustain populations. There is a need, however, to evaluate existing quantitative methods that seek to test relations between landscape structure and genetic structure.

Objectives: Study objectives were (1) to evaluate the utility of using maximum-likelihood population-effects models to identify landscape features that affect dispersal and (2) to identify which model selection indices work best for this application.

Methods: Landscape resistance surfaces for GRSG were developed using land cover (sagebrush, forest, agriculture) and terrain ruggedness summarized at a 6.44-kilometer radius. Dispersal of 37 GRSG populations (defined on the basis of large leks) was simulated such that associated genetic diversity and differentiation matched 14 available empirical datasets.

Location: Wyoming; MZ I, MZ II

Findings: The coefficients of selected models generally reflected the underlying (simulated) dispersal model. Akaike information criteria (AIC) and Bayesian information criteria (BIC) outperformed three other indices, including two different marginal $\mathrm{R}^{2}$ values, in their utility for model selection. Even AIC and BIC (the top performer), however, were not always able to identify the true dispersal surface when it was based on a combination of multiple landscape surfaces.

Implications: The study presents new methods to improve researchers' ability to identify landscape characteristics that affect species dispersal and genetic structure. More work is needed, however, to refine the approaches and compare error rates across additional landscapes using more complex simulations and different sampling strategies, genetic markers, and modeling approaches.

Topics: agricultural conversion, behavior or demographics, broad-scale habitat characteristics, genetics, new geospatial data 


\section{Row, J.R., Oyler-McCance, S.J., and Fedy, B.C., 2016, Differential influences of local subpopulations on regional diversity and differentiation for greater sage-grouse (Centrocercus urophasianus): Molecular Ecology, v. 25, no. 18, p. 4424-4437.}

DOI: https://doi.org/10.1111/mec.13776

Background: Local population dynamics and dispersal among populations both combine to affect genetic variation within a species across a region. This genetic variation can affect how the species is able to respond to future population disturbances, habitat losses, and other changes.

Objectives: Study objectives were (1) to explore regional differences in GRSG subpopulation densities and dispersal rates and (2) to quantify how these differences may influence regional genetic variation.

Methods: The authors used demographic and genetic data from 10 subpopulations of GRSG to parameterize a simulated approximate Bayesian computation model, which they used to explore the study objectives.

Location: Wyoming; MZ I, MZ II

Findings: The authors found substantial variation in GRSG subpopulation density and dispersal across Wyoming, with higher population sizes and densities in the southern portion of the state. Most subpopulations had net immigration rates whose distribution overlapped with zero, but a few populations had positive or negative net immigration (that is, sink or source populations, respectively). Differences in dispersal had a strong effect on regional genetic differentiation; differences in density had a strong effect on genetic diversity among subpopulations.

Implications: Study results provide insight into the differing influences of population and dispersal characteristics on genetic variability across space. They also suggest that decreases in the size and dispersal rates of source populations that are centrally located may have the largest negative effect on regional genetic differentiation.

Topics: behavior or demographics, genetics, new geospatial data, population estimates or targets 


\section{Row, J.R., Oyler-McCance, S.J., Fike, J.A., O'Donnell, M.S., Doherty, K.E., Aldridge, C.L., Bowen, Z.H., and Fedy, B.C., 2015, Landscape characteristics influencing the genetic structure of greater sage-grouse within the stronghold of their range-A holistic modeling approach: Ecology and Evolution, v. 5, no. 10, p. 1955-1969.}

DOI: https://doi.org/10.1002/ece3.1479

Background: Given the substantial population declines and habitat losses GRSG have experienced across their range, it is important to understand both the extent to which current populations are functionally connected through gene flow and the environmental factors that may affect that connectivity.

Objectives: Study objectives were to identify (1) the spatial scale and landscape resistance factors that best characterize functional connectivity of GRSG, (2) whether effective (genetic) dispersal of GRSG is related to seasonal habitat preferences, (3) whether using habitat suitability indices adds value over and above landscape metrics in understanding gene flow across the landscape, and (4) which model selection metrics may be most suitable for this application.

Methods: The study used 949 GRSG DNA samples collected primarily from 37 lek groups across Wyoming between 2007 and 2010. Landscape resistance surfaces were developed using forest, sagebrush, agriculture, terrain ruggedness, and road variables and nesting, summer, and winter habitat suitability indices from a previous study. Moving windows with radii of 1.5 kilometers $(\mathrm{km}), 6.44 \mathrm{~km}$, and $17.33 \mathrm{~km}$ were used to calculate landscape metrics.

\section{Location: Wyoming; MZ I, MZ II}

Findings: Genetic differentiation was most strongly related to the distribution of low-quality (that is, high-resistance) nesting and winter habitat across the landscape quantified at a broad spatial scale (radii of $17.33 \mathrm{~km}$ and $6.44 \mathrm{~km}$, respectively). Forest cover, sagebrush cover, and terrain ruggedness at scales of $1.5 \mathrm{~km}$ to $17.33 \mathrm{~km}$ were also quite important in understanding genetic dispersal, with anthropogenic variables (especially roads) generally less important.

Implications: The distribution of low-quality (high-resistance) nesting and winter habitats at broad spatial scales appeared most important for GRSG dispersal, possibly driven by yearling GRSG searching for suitable nesting habitat after leaving wintering habitat. Further, the spatial distribution of very unsuitable (that is, very high resistance) habitat may be more important than differing qualities of suitable habitat for dispersing GRSG. Results highlighted the importance of considering the distribution and quality of seasonal habitats across the landscape in understanding functional connectivity of GRSG populations, as well as the importance of further examination of model selection criteria.

Topics: agricultural conversion, behavior or demographics, broad-scale habitat characteristics, effect distances or spatial scale, genetics, infrastructure (roads, pipelines, powerlines, cell towers), new geospatial data 


\section{*2019 Update* Rowland, M.M., 2019, The effects of management practices on grassland birds - Greater Sage-Grouse (Centrocercus urophasianus), chap. B of Johnson, D.H., Igl, L.D., Shaffer, J.A., and DeLong, J.P., eds., The effects of management practices on grassland birds: U.S. Geological Survey Professional Paper 1842, p. 50.}

DOI: https://doi.org/10.3133/pp1842B

Background: GRSG use many different seasonal habitats throughout the year and the species' range, from southern Canada to southern Utah, spans substantial environmental gradients. Maintaining expansive stands of sagebrush with abundant understory forbs is key for GRSG management.

Objectives: The author's objectives were to use published literature to describe GRSG habitat needs, area requirements, and the effects of various land management practices on GRSG.

Methods: Using a literature synthesis approach, the author described a substantial body of work relating to GRSG habitats and effects of rangeland management on this species.

Location: range-wide; MZ I, MZ II, MZ III, MZ IV, MZ V, MZ VI, MZ VII

Findings: The author synthesized information on GRSG habitat at leks, nests, brood-rearing locations, winter sites, and roosting, foraging, and loafing areas throughout much of the GRSG range. They provide information on landscape-scale habitat needs, brood parasitism by cowbirds, and GRSG breeding phenology and site fidelity. The author focused on GRSG response to five main management topics: fire, grazing, pesticides/herbicides, energy/urban development, and translocation.

Implications: After presenting past work, the author provided management recommendations based on the literature review. This information will be helpful to resource managers, as it provides a comprehensive summary of past research findings related to GRSG habitat requirements and management issues.

Topics: agricultural conversion, behavior or demographics, broad-scale habitat characteristics, energy development, ex-urban development, fences, fire or fuel breaks, habitat restoration or reclamation, habitat selection, herbivory/grazing, human dimensions or economics, infrastructure (roads, pipelines, powerlines, cell towers), mining, non-native invasive plants, range mgmt. structures (water developments, mineral licks), sagebrush removal, site-scale habitat characteristics, survival, translocation, weather and climate 


\section{*2019 Update* Runge, C.A., Plantinga, A.J., Larsen, A.E., Naugle, D.E., Helmstedt, K.J., Polasky, S., Donnelly, J.P., Smith, J.T., Lark, T.J., Lawler, J.J., Martinuzzi, S., and Fargione, J., 2019, Unintended habitat loss on private land from grazing restrictions on public rangelands: Journal of Applied Ecology, v. 56, no. 1, p. 52-62.}

DOI: https://doi.org/10.1111/1365-2664.13271

Background: Proposals seeking to restrict grazing on public lands could lead to increased conversion of private rangelands to croplands, resulting in a net decrease in habitat for species such as GRSG.

Objectives: The authors' goal was to assess whether restricting grazing access on public lands could lead to increased GRSG habitat loss via conversion of private rangeland into cropland.

Methods: Researchers used data on past land use change as well as ranch and cropland profitability information to model profitability and land use in the western U.S.

Location: range-wide; MZ I, MZ II, MZ III, MZ IV, MZ V, MZ VI, MZ VII

Findings: Restricting grazing on public lands by 50 percent was expected to result in the loss of 171,000 ha of GRSG habitat by 2050. Much of this habitat loss was predicted to occur in mesic areas important for brood rearing. An additional 842,000 ha are predicted to be lost regardless of new restrictions.

Implications: Restricting grazing on public lands could result in increased GRSG habitat loss on private land over the next 30 years. It is important to consider the connections between public land policy and private land use change. Policies that balance the need to conserve habitat on public lands with economic needs of ranchers are promising.

Topics: broad-scale habitat characteristics, herbivory/grazing, human dimensions or economics 


\section{*2019 Update* Runge, C.A., Withey, J.C., Naugle, D.E., Fargione, J.E., Helmstedt, K.J., Larsen, A.E., Martinuzzi, S., and Tack, J.D., 2019, Single species conservation as an umbrella for management of landscape threats: Plos One, v. 14, no. 1, p. E0209619.}

DOI: https://doi.org/10.1371/journal.pone.0209619

Background: There is concern that "single species" or "umbrella species" conservation may not be effective for protecting less charismatic, non-target species. Conservation actions targeting GRSG are often large-scale and they are wide-spread across much of the western U.S. However, the extent to which these efforts benefit co-occurring species is unknown.

Objectives: The goal of this study was to assess the extent to which GRSG conservation efforts may protect co-occurring species from threats at local- and landscape-scales.

Methods: The authors quantified the extent to which GRSG Priority Areas for Conservation (PACs) overlap with the distributions of 81 different sagebrush-associated species of vertebrates. They compared this overlap to overlap values derived from a multi-species conservation approach and the 81 sagebrush-associate species.

Location: range-wide; MZ I, MZ II, MZ III, MZ IV, MZ V, MZ VI, MZ VII

Findings: There was no statistical difference between the PAC approach and the multi-species approach in terms of percentage of habitat overlap with the other 81 species. On average, 24.8 percent of the other species' sagebrush habitat overlapped with the PACs.

Implications: The authors conclude that PACs designed for GRSG conservation provide a potential conservation benefit similar to that derived from a multi-species conservation approach. Their method of comparing umbrella species conservation to multi-species conservation approaches could be used in other ecosystems as well.

Topics: broad-scale habitat characteristics, other topic 


\section{Sandford, C.P., Kohl, M.T., Messmer, T.A., Dahlgren, D.K., Cook, A., and Wing, B.R., 2017, Greater sage-grouse resource selection drives reproductive fitness under a conifer removal strategy: Rangeland Ecology and Management, v. 70, p. 59-67.}

DOI: https://doi.org/10.1016/j.rama.2016.09.002

Background: Though the link between resource selection and individual fitness is foundational to population ecology, little is known about whether management actions (here, conifer removal) taken to increase habitat availability lead to increased fitness at the individual or population level.

Objectives: Study objectives were (1) to assess resource selection of female GRSG in relation to conifer removal projects and (2) to evaluate to what extent nest and brood success were related to individual habitat selection.

Methods: The authors marked and monitored 96 female GRSG during the lekking and nesting seasons between 2012 and 2015. Brood success was evaluated at 50 days. Habitats were classified based on data on canopy cover class, elevation, mesic habitats, and distance to anthropogenic uses (roads, power lines, agriculture, and non-urban development).

Location: northwestern Utah; MZ IV

Findings: Distance to conifer removal treatment was the sole factor related to GRSG nest success, with success being lower in nest sites farther from conifer removal treatments. Selected brooding habitats were closer to conifer removal areas and non-urban development, farther from roads and agriculture, higher in elevation, and lower in canopy cover. Brood success tended to be higher when females selected areas closer to conifer removal treatments and areas with minimal conifer canopy cover.

Implications: This study demonstrated a positive relation between conifer removal treatments (mechanical removals across large areas adjacent to occupied GRSG habitat) and measures of increased reproductive success (probability of nest and brood success). The authors also noted multiple nesting attempts in recent $(<5$ year old) conifer treatment areas, suggesting that such treatments can increase the availability of suitable habitat in the short term.

Topics: agricultural conversion, behavior or demographics, broad-scale habitat characteristics, conifer expansion, effect distances or spatial scale, ex-urban development, habitat restoration or reclamation, habitat selection, infrastructure (roads, pipelines, powerlines, cell towers), site-scale habitat characteristics 


\section{Schreiber, L.A., Hansen, C.P., Rumble, M.A., Millspaugh, J.J., Gamo, R.S., Kehmeier, J.W., and Wojcik, N., 2015, Microhabitat selection of brood-rearing sites by greater sage-grouse in Carbon County, Wyoming: Western North American Naturalist, v. 75, no. 3, p. 348-363.}

DOI: https://doi.org/10.3398/064.075.0312

Background: Low survival of GRSG chicks may have contributed to the decline of the species and may be related to food and cover characteristics of brood-rearing sites. Both forbs and arthropods are important food sources for GRSG chicks, and vegetation cover at brood-rearing sites may affect chick mortality rates from predation and exposure.

Objectives: Study objectives were (1) to identify vegetation and arthropod characteristics of microsites selected for brood rearing and (2) to estimate how these characteristics might affect the probability of brood site selection.

Methods: The authors tagged and monitored 146 adult brood-rearing GRSG hens in 2011-2013 and sampled vegetation (including cheatgrass) and arthropods at 105 brood-rearing sites and 315 nearby random sites (50 meters [m], $250 \mathrm{~m}$, and $500 \mathrm{~m}$ distant).

Location: Wyoming; MZ II

Findings: Brood-rearing GRSG selected areas that had greater vertical visual obstruction, greater vegetation cover (to about 75 percent cover, decreasing thereafter), greater numbers of arthropods in the order Diptera (flies), and fewer arthropods in the order Coleoptera (beetles). Top models included both interactions and nonlinear effects. In both years, visual obstruction explained the most variability in selection of brood-rearing sites. While GRSG selected a wide variety of vegetation types for brood rearing, they often selected mesic vegetation communities.

Implications: Both vegetation and arthropod characteristics explained significant variability in selection of brood-rearing sites, suggesting that both are important to consider in assessing habitat suitability for GRSG brood rearing. Characteristics of different vegetation communities may be more important in understanding brood site selection than individual attributes within vegetation community types, supporting community-level management approaches.

Topics: effect distances or spatial scale, habitat selection, non-native invasive plants, site-scale habitat characteristics 


\section{Schreiber, L.A., Hansen, C.P., Rumble, M.A., Millspaugh, J.J., Thompson, F.R., Gamo, R.S., Kehmeier, J.W., and Wojik, N., 2016, Greater sage-grouse apparent nest productivity and chick survival in Carbon County, Wyoming: Wildlife Biology, v. 22, no. 2, p. 37-44.}

DOI: https://doi.org/10.2981/wlb.00124

Background: Increasing energy development is altering landscapes within the GRSG range. Effective mitigation and management actions in these landscapes require an understanding of GRSG vital rates in areas of energy development. GRSG nest success and chick survival strongly influence GRSG population growth; both vary spatially and temporally, in part because of weather, vegetation structure, and population characteristics.

Objectives: Study objectives were (1) to estimate apparent nest productivity, (2) to estimate chick survival rates, (3) to identify biological and environmental factors correlating with chick survival, and (4) to establish baseline rates and variability for both nest productivity and chick survival in light of a planned wind energy development in Carbon County, Wyoming.

Methods: The authors monitored nests associated with 142 tagged adult female GRSG in 20112013, estimated the number of successfully hatched chicks from each nest, and monitored broodrearing females and their chicks (37 broods total) every 1-2 weeks. Apparent net nest productivity was calculated based on the weighted average brood size. Chick survival was modeled using a modified logistic-exposure model and examined for correlations with chick age, hatch date, temperature, and precipitation.

Location: Wyoming; MZ II

Findings: Apparent nest productivity was lowest (1.54 chicks/female) in 2013 and highest (2.79 chicks/female) in 2011. Chicks' 70-day survival probabilities varied from a low of 4.2 percent in 2012 to a high of 19.1 percent in 2011. The top model for chick survival included year, chick age, and average daily temperature between hatch date and surveys.

Implications: Chick survival rates were substantially lower in 2012 (a drought year) compared to the other 2 years, consistent with findings from multiple other studies. Chick survival rates and net nest productivity were variable and susceptible to environmental conditions. The authors suggested that management actions that increase food and cover availability, especially in drought years and years with warm springs, may be needed. Baseline results from this study can be used to evaluate potential effects of the planned wind energy development on GRSG productivity.

Topics: behavior or demographics, survival, weather and climate 
*2019 Update* Schroff, S.R., Cutting, K.A., Carr, C.A., Frisina, M.R., McNew, L.B., and Sowell, B.F., 2018, Characteristics of shrub morphology on nest site selection of greater sagegrouse (Centrocercus urophasianus) in high-elevation sagebrush habitat: Wilson Journal of Ornithology, v. 130, no. 3, p. 730-738.

DOI: https://doi.org/10.1676/17-086.1

Background: GRSG reproductive success is strongly influenced by the fine-scale habitat selected for nest sites. Understanding the vegetation characteristics selected by female GRSG in specific regions may help resource managers increase recruitment rates into GRSG populations.

Objectives: The goal of this study was to determine which fine-scale vegetation characteristics female GRSG select for in their choice of nest sites.

Methods: Fine-scale vegetation conditions at 90 nest sites were compared to those at paired random locations across two different breeding seasons.

Location: Montana; MZ IV

Findings: Most nests were located under individual shrubs that provided relatively high amounts of lateral cover, such as that provided by mountain big sagebrush and three-tip sagebrush. Basin big sagebrush was used, but less frequently, as this species provided less lateral cover than the other two sagebrush types. At the fine-scale, herbaceous vegetation cover was not an important predictor of nest sites.

Implications: In southwest Montana, protection of intact stands of mountain big sagebrush and three-tip sagebrush may benefit GRSG by providing higher quality nesting habitat during the breeding season than other sagebrush types.

Topics: behavior or demographics, habitat selection, site-scale habitat characteristics 
Severson, J.P., Hagen, C.A., Maestas, J.D., Naugle, D.E., Forbes, J.T., and Reese, K.P., 2017, Effects of conifer expansion on greater sage-grouse nesting habitat selection: Journal of Wildlife Management, v. 81, no. 1, p. 86-95.

DOI: https://doi.org/10.1002/jwmg.21183

Background: Native pinyon and juniper woodlands have expanded substantially, primarily into sagebrush ecosystems, and conifer expansion is considered a primary threat to GRSG in the Great Basin. Limited information exists, however, on how conifer expansion may affect GRSG habitat selection.

Objectives: Study objectives were (1) to evaluate effects of conifer expansion on GRSG selection of nesting sites and (2) to identify the spatial scale of such effects.

Methods: The authors surveyed 160 GRSG nests and 167 associated sites in 2010 and 2011. They tested to what extent vegetation variables measured at the site scale; conifer canopy cover, conifer clustering, and topographic variables calculated at six broader spatial scales (radii of 50 meters $[\mathrm{m}]$ to $1,200 \mathrm{~m}$ ); and distance to nearest active lek were important in explaining variability in the selection of nesting sites.

Location: southeastern Oregon; MZ V

Findings: The most important variables influencing relative probability of nesting were shrub and forb cover (both positive relations), followed by conifer clustering and canopy cover (both strongly negative after a threshold was reached, and both summarized at the $800-\mathrm{m}$ scale). The model also included elevation, terrain ruggedness (summarized at both $1,200 \mathrm{~m}$ and $100 \mathrm{~m}$ ), aspect, sagebrush cover (positive relation), shrub type, landform (summarized at 1,200 m), and richness of forbs known to be important for nesting and brood-rearing GRSG (positive relation).

Implications: The authors expressed concern regarding limitation of otherwise suitable GRSG nesting habitat by low levels ( 3 percent) of conifer canopy cover, particularly as the preferred shrub types in this study tend to be quite susceptible to conifer expansion. Limiting conifer canopy cover to less than 3 percent within $800 \mathrm{~m}$ of potential nesting sites by using conifer removal methods that minimize shrub loss may be necessary to maintain current availability of nesting habitat.

Topics: broad-scale habitat characteristics, conifer expansion, effect distances or spatial scale, habitat restoration or reclamation, habitat selection, site-scale habitat characteristics 


\section{Severson, J.P., Hagen, C.A., Maestas, J.D., Naugle, D.E., Forbes, J.T., and Reese, K.P., 2017, Restoring sage-grouse nesting habitat through removal of early successional conifer: Restoration Ecology, v. 25, no. 6, p. 1026-1034.}

DOI: https://doi.org/10.1111/rec.12524

Background: Conifer expansion has been recognized as a threat to GRSG habitat suitability. Understanding the effect of conifer treatments on understory vegetation and habitat use by GRSG is important for successful habitat management.

Objectives: This research sought (1) to determine the effects of conifers on understory vegetation, (2) to determine effects of vegetation changes following conifer removal on GRSG nesting habitat, and (3) to compare results to published literature to assess progress of treatments towards desirable conditions.

Methods: The authors used a controlled repeated measures experimental design. Treatments consisted of hand-cutting conifers in sites where understory shrubs and herbaceous plants were still either dominant or codominant. The authors measured vegetation at site and stand scales annually from 2012 to 2014 at 12 random vegetation monitoring locations each in treatment areas and in both onsite and offsite control areas to determine changes in understory vegetation 1-3 years after treatment. The authors tagged and monitored female GRSG during the nesting seasons of 2010-2014 and monitored 356 GRSG nests in the same area to quantify characteristics of selected nest sites. Vegetation survey data were compared to an existing metaanalysis and to the Bureau of Land Management Sage-Grouse Habitat Assessment Framework guidelines (hereafter, the guidelines).

\section{Location: southeastern Oregon; MZ V}

Findings: Increased conifer cover was associated with decreased forb richness and cover, herbaceous cover, and shrub richness and cover. Conifer removal increased perennial grass cover, tall herbaceous cover, and sagebrush height. Vegetation monitoring points in both treated and control areas had lower vegetation cover than both nest sites and values from the metaanalysis; they were categorized as marginal per the guidelines. Prior to treatment, perennial grass cover was unsuitable according to the guidelines, but it improved to marginal status after 1 year post treatment.

Implications: Negative effects of conifer cover on vegetation characteristics important for GRSG nesting were observed. Not all vegetation characteristics responded to conifer removal within 3 years, but observed changes did tend to increase habitat suitability according to the guidelines. A slight (but non-significant) increase in invasive annual grass cover was observed in treatment sites, which the authors suggested warrants further investigation. The authors anticipated longer term increases in shrub cover based on the increased sagebrush height and positive response of herbaceous vegetation cover after treatment.

Topics: conifer expansion, habitat restoration or reclamation, habitat selection, non-native invasive plants, site-scale habitat characteristics 


\section{Severson, J.P., Hagen, C.A., Maestas, J.D., Naugle, D.E., Forbes, J.T., and Reese, K.P., 2017, Short-term response of sage-grouse nesting to conifer removal in the northern Great Basin: Rangeland Ecology and Management, v. 70, p. 50-58.}

DOI: https://doi.org/10.1016/j.rama.2016.07.011

Background: Conifers are expanding into sagebrush ecosystems in many areas of the west, and they can increase perch availability for GRSG predators. Conifer removal is one strategy for maintaining GRSG populations, but its effect on GRSG has not been well studied.

Objectives: To study the short-term (2-4 year) effects of conifer removal treatments on GRSG nesting habitat and site selection, the authors sought to quantify changes in (1) the number of GRSG nests in and near conifer removal areas, (2) available nesting habitat associated with treatments, and (3) the number of GRSG nests in treated areas of mountain big sagebrush.

Methods: The authors conducted an experiment using a before-after-control-impact design; they used conifer removal treatments designed to retain shrubs and conducted the experiment where conifers were not yet dominant. The authors tagged 243 GRSG females from 2009 to 2014 and monitored them during the nesting season. Treatment variables included years since treatment, years since cut/slash burn, proportion of area cut, and distance to closest cut.

\section{Location: southeastern Oregon; MZ V}

Findings: Conifer removal treatment significantly increased both the area of available nesting habitat and the number of nests in mountain big sagebrush (where conifer encroachment was greatest and most of the removal occurred). The top nest site selection model included years since cut (positive relation) and distance to nearest cut (negative relation), with the latter having the greatest influence, indicating a shift of nests toward treated areas.

Implications: Conifer removal, particularly within 1,000 meters of occupied GRSG habitat, may increase the probability of nest site selection in the short term when available nesting habitat is limiting. Collaborating across boundaries to plan conifer removals at large scales may be needed to achieve benefits for GRSG. More studies across different life history stages and over longer time periods are needed to better understand the effects of conifer removal on GRSG.

Topics: broad-scale habitat characteristics, conifer expansion, effect distances or spatial scale, habitat restoration or reclamation, habitat selection, site-scale habitat characteristics 


\section{Severson, J.P., Hagen, C.A., Tack, J.D., Maestas, J.D., Naugle, D.E., Forbes, J.T., and Reese, K.P., 2017, Better living through conifer removal-A demographic analysis of sage-grouse vital rates: PLOS ONE, v. 12, no. 3, article e0174347, 17 p.}

DOI: https://doi.org/10.1371/journal.pone.0174347

Background: Conifer expansion is a major threat to the sagebrush biome that degrades range condition, increases perches for predators, and decreases and fragments habitat for sagebrushobligate species. Conifer removal has been recommended to help conserve GRSG, but few studies have addressed how population demographics may respond to removal treatments.

Objectives: To study the effects of conifer removal treatments on GRSG survival and nest survival, the authors sought (1) to quantify changes in female GRSG survival after conifer removal, (2) to identify during what season/life history stage effects on female GRSG survival may be most apparent, (3) to evaluate changes in GRSG nest survival after conifer removal, and (4) to assess the effect of treatment on GRSG population growth rate.

Methods: The study was conducted using a before-after-control-impact experimental design, with nearly all conifer removals occurring by hand in locations with intact understory communities. To assess survival, the authors tagged and monitored 219 female GRSG from 2009 to 2014 and monitored 225 nests until incubation ended between 2011 and 2014. Program MARK (software used to analyze data from marked individuals) was used to calculate survival of female GRSG and nests, and multiple models were considered to evaluate treatment effects.

Location: southeastern Oregon; MZ V

Findings: There was evidence of a positive treatment effect for female survival and nest survival, resulting in an estimated 25 percent increase in the population growth rate in the large (34,000 hectare) treatment area compared to the control area. Within 3 years of conifer removal, the estimated population growth rate increased by 25 percent in the treatment area relative to the control area.

Implications: Conifer removal appears to increase survival of both female GRSG and nests, which may lead to greater population growth over time. Treatments covered approximately 20 percent of the study area, and treatment effects were assessed at the landscape scale. Additional studies are needed over longer time periods and on different life history parameters to better understand potential effects of conifer removal on individuals and populations at different scales.

Topics: behavior or demographics, conifer expansion, habitat restoration or reclamation, population estimates or targets, survival 
*2019 Update* Severson, J.P., Coats, P.S., Porchazka, B.G., Ricca, M.A., Casazza, M.L., and Delehanty, D.J., 2019, Global positioning system tracking devices can decrease Greater Sage-grouse survival: The Condor, v. 121, p. 1-15.

DOI: https://doi.org/10.1093/condor/duz032

Background: When conducting studies on animal populations or movements, marking individuals with a tag, transmitter, or other similar means, is necessary to follow them through time or space. Models based on these data assume marked individuals have mortality rates, behaviors, and reproductive rates that are equal to those of unmarked individuals, the population marked individuals are intended to represent. If this assumption is violated, models will produce incorrect, or biased, estimates of survival or behavior for the greater population. GRSG movement and survival are now often monitored by attaching rump-mounted GPS devices to individuals. However, this new technology may influence demographic rates, such as survival probability, differently than older tracking technology such as VHF transmitters biasing results of studies where GPS tracking was employed.

Objectives: The objective of this research was to compare GRSG survival rates between individuals fitted with necklace-attached VHF transmitters and rump-mounted GPS devices.

Methods: VHF transmitters were fitted to 821 female and 52 male GRSG and GPS devices were fitted to 234 female and 125 male GRSG from 2012 to 2017. Individuals were from multiple age classes and populations. Survival rates were determined and compared for birds with different transmitter types by age class.

Findings: GPS-marked GRSG had substantially lower survival rates than VHF-marked individuals across sex, age, and seasonal groups. Survival differences were most pronounced for adult females across all seasons, especially during spring, but differences decreased for larger females relative to device weight. Results suggested that much of the discrepancy in survival rates was due to the positioning of heavier devices relative to bird weight for rump-mounted GPS, but not for necklace-mounted VHF devices, indicating that the location of attachment on the bird could be an important factor.

Implications: The authors conclude that knowing survival tradeoffs associated with GPSmarking individuals can help resource managers and scientists make informed decisions about employing this technology and about interpreting results of demographic studies conducted using these devices.

Topics: behavior or demographics, effect distances or spatial scale, habitat selection, site-scale habitat characteristics, survival 
*2019 Update* Shinneman, D.J., Aldridge, C.L., Coates, P.S., Germino, M.J., Pilliod, D.S., and Vaillant, no. M., 2018, A conservation paradox in the great basin-altering sagebrush landscapes with fuel breaks to reduce habitat loss from wildfire: US Geological Survey Open File Report 2018-1034, 70 p.

DOI: https://doi.org/10.3133/ofr20181034

Background: Fuel breaks, intended to help reduce wildfire intensity and size, have been recently highlighted as a mechanism to protect remaining GRSG habitat, especially in the Great Basin, where invasive plants and wildfire are especially problematic. However, implementing and maintaining fuel breaks paradoxically results in the direct and indirect loss or alteration of hundreds of thousands of hectares of GRSG habitat, with relatively little published evidence of effectiveness in reducing wildfire spread.

Objectives: The authors' goal was to summarize the published literature documenting fuel break effectiveness, effects on sagebrush plant communities, and effects on GRSG and other wildlife species, while providing an overview of federal policies related to fire suppression, fire behavior, and fire trends in sagebrush habitats of the Great Basin.

Methods: A comprehensive literature search was conducted for published studies, agency databases, and federal policy related to fuel breaks in sagebrush habitats of the Great Basin.

Location: range-wide; MZ I, MZ II, MZ III, MZ IV, MZ V, MZ VI, MZ VII

Findings: Fuel breaks are important in federal agency plans for reducing wildfire in the Great Basin. More information is needed regarding the effectiveness of fuel breaks at altering wildfire behavior and reducing wildfire sizes. The spread of non-native plant species via fuel breaks remains a concern. Little information exists regarding the impacts of fuel breaks on wildlife species, however the authors draw some parallels with past studies documenting impacts of sagebrush removal for grazing purposes, or studies examining the effects of patch size on habitat suitability for sagebrush associated wildlife.

Implications: The authors conclude that more research is needed to document fuel break effectiveness and their effects on plant communities and wildlife. However, they suggest that installing fuel breaks to protect intact sagebrush habitat may provide long-term benefits to sagebrush-associated species, even if these benefits come at a cost to some individual species at local scales.

Topics: broad-scale habitat characteristics, effect distances or spatial scale, fire or fuel breaks, human dimensions or economics, non-native invasive plants, sagebrush removal 


\section{*2019 Update* Shinneman, D.J., Germino, M.J., Pilliod, D.S., Aldridge, C.L., Vaillant, N.M., and Coates, P.S., 2019, The ecological uncertainty of wildfire fuel breaks: examples from the sagebrush steppe: Frontiers in Ecology and Environment, v. 17, no. 5, p. 279-289.}

DOI: https://doi.org/10.1002/fee.2045

Background: Fuel breaks implemented to help protect habitat for species such as GRSG also cause fragmentation of the very habitats that they are intended to protect.

Objectives: The goal of this review was to assess how fuel break installation might alter ecosystems, create edge effects, serve as vectors for plant and wildlife invasions, and fragment intact landscapes. The authors also evaluate how new science could help improve our understanding of ecological costs and benefits of fuel break installation.

Methods: The authors review the literature on wildfire in the Great Basin and examine published and potential ecological effects of fuel breaks in sagebrush habitats.

Location: range-wide; MZ I, MZ II, MZ III, MZ IV, MZ V, MZ VI, MZ VII

Findings: Although there is some evidence that fuel breaks are effective, more detailed studies are needed to document the overall benefit they provide to wildfire suppression. There is a lack of peer-reviewed literature regarding the ecological effects of fuel breaks.

Implications: More research is needed to produce a robust cost-benefit analysis regarding fuel break effectiveness and ecological impacts. The authors suggest several specific research questions that would provide valuable information to policy and decision-makers.

Topics: broad-scale habitat characteristics, effect distances or spatial scale, fire or fuel breaks, human dimensions or economics, non-native invasive plants, sagebrush removal 


\section{Shirk, A.J., Schroeder, M.A., Robb, L.A., and Cushman, S.A., 2015, Empirical validation of landscape resistance models-Insights from the greater sage-grouse (Centrocercus urophasianus): Landscape Ecology, v. 30, no. 10, p. 1837-1850.}

DOI: https://doi.org/10.1007/s10980-015-0214-4

Background: Resistance models quantify how landscape features may impede the ability of individuals (or their genes) to move across the landscape. Resistance models are widely used to understand functional connectivity of species, but the performance of resistance models that are based on expert opinion is rarely evaluated.

Objectives: Study objectives were to assess the influence of the following factors on the performance of resistance models: (1) expert-based (versus empirical) model parameters, (2) spatial and thematic resolution of the input data, and (3) species (versus landscape) focus of the model.

Methods: The authors evaluated three resistance models: (1) a coarse spatial- and thematicresolution model (11 land cover classes, resampled to 100-meter [m] pixels) based on expert input, (2) a fine spatial- and thematic-resolution model (30 land cover classes plus additional development attributes, 30-m pixels) based on expert input, and (3) a fine-resolution model based on human modification categories (such as roads, agriculture, transmission lines, wind turbines). An additional 78 models were included to test alternate values for parameters with large uncertainty. All of these models were evaluated for their ability to predict existing patterns of lek occupancy (based on multiple surveys of 70 lek complexes) and genetic differentiation (325 samples) across the landscape.

Location: Washington; MZ VI

Findings: Resistance models based on species-specific data at fine spatial and thematic resolutions were best able to predict existing GRSG lek and genetic patterns. Expert-based models at both resolutions tended to underpredict resistance associated with low elevations and transmission lines and overpredict resistance associated with land cover (especially Conservation Reserve Program (CRP) land and nonirrigated agriculture). Models based on human modification also performed poorly, likely because of the ability of GRSG to move efficiently through some modified land-cover types such as dryland wheat and CRP fields.

Implications: Resistance models for GRSG will benefit from the use of fine-scale, speciesspecific data that describe how and at what scale GRSG are thought to respond to variation in the landscape.

Topics: agricultural conversion, behavior or demographics, effect distances or spatial scale, energy development, ex-urban development, genetics, infrastructure (roads, pipelines, powerlines, cell towers), new geospatial data 


\section{Shirk, A.J., Schroeder, M.A., Robb, L.A., and Cushman, S.A., 2017, Persistence of greater sage-grouse in agricultural landscapes: Journal of Wildlife Management, v. 81, no. 5, p. 905-918.}

DOI: https://doi.org/10.1002/jwmg.21268

Background: GRSG in Washington occur in a highly modified landscape, currently occupying about 8 percent of their historical range. After multiple decades of decline, the population appears to have stabilized, coincident with implementation of the Federal Conservation Reserve Program (CRP) in the state.

Objectives: Study objectives were (1) to assess the value of CRP fields in providing seasonal habitat, (2) to assess the sensitivity of GRSG to the spatial configuration of CRP and sagebrush, (3) to evaluate the effect of alternative CRP scenarios (no CRP, spatially focused CRP) on potential habitat area, and (4) to identify other environmental factors limiting potential habitat availability and the spatial scale of their effect.

Methods: The authors used occurrence records of breeding age GRSG from 1992 to 2014 and defined breeding, nesting, brood rearing, and winter seasons based on the observed behavior of the birds. They quantified 21 habitat configuration, land use/land cover, development, topography, and climate variables at multiple scales (site, 30 meters; home range, 1-kilometer radius; and lek, 5-kilometer radius) and used them to develop seasonal species distribution models based on maximum entropy.

Location: Washington; MZ VI

Findings: Potential habitat in most seasons was most strongly related to habitat variables (native sagebrush, CRP) at the lek scale, habitat configuration, and distance to transmission lines. Distance to sagebrush at the home-range scale, distance to roads, and summer temperature and precipitation were also important in some seasons. Simulated changes in CRP enrollment and configuration substantially altered the amount of potential GRSG habitat in the study area.

Implications: In Washington, CRP fields play an important role in augmenting native GRSG habitat. Spatial targeting of CRP enrollment near existing areas of sagebrush steppe could substantially increase available habitat for GRSG and improve connectivity between occupied habitat patches.

Topics: agricultural conversion, broad-scale habitat characteristics, effect distances or spatial scale, ex-urban development, habitat restoration or reclamation, habitat selection, infrastructure (roads, pipelines, powerlines, cell towers), new geospatial data, site-scale habitat characteristics, weather and climate 
*2019 Update* Shyvers, J.E., Walker, B.L., and Noon, B.R., 2018, Dual-frame lek surveys for estimating greater sage-grouse populations: Journal of Wildlife Management, v. 82, no. 8, p. $1689-1700$.

DOI: https://doi.org/10.1002/jwmg.21540

Background: Monitoring wildlife populations in a robust, defensible manner is time intensive and costly. However, the information provided by such efforts is critical for managing species with high temporal variability at local and regional spatial scales. Currently, many population indices rely on assumptions that are largely untested. Monitoring programs for annual lek counts of male GRSG often assume that the proportion of leks monitored is high relative to the total number of leks on the landscape of interest, the number of leks monitored is relatively constant across years, and count data adequately represent true population abundances.

Objectives: The goal of this study was to assess whether commonly held assumptions regarding male GRSG lek count data are reasonable by employing sampling approaches that allow for estimates of detectability of active leks and detectability of individual male GRSG at active leks.

Methods: The authors used "dual-frame" surveys, whereby male counts were performed at known, active leks and areas were searched for previously unknown, active leks. They combined information from the two aspects of the dual-frame survey with occupancy analyses to estimate the number of active leks, lekking males, and the proportion of total leks and total males within the study area that are counted on an annual basis after accounting for imperfect detection.

Location: Colorado; MZ II

Findings: Within this study area, the authors estimate that if annual lek surveys were only conducted at leks where one or more males were detected in the past five years, just 45-75 percent of active leks, and a similar percentage of lekking males, would be detected per year.

Implications: These results show that many active leks are likely to be unknown by resource managers or scientists and will not be reflected in annual lek count data. Further, the proportion of active leks and lekking males counted varies across years. The authors suggest accounting for imperfect detection in trend analyses and using dual-frame surveys if possible.

Topics: behavior or demographics, broad-scale habitat characteristics, habitat selection, population estimates or targets 


\section{Sinai, N.L., Coates, P.S., Andrle, K.M., Jefferis, C., Senties-Cue, C.G., and Pitesky, M.E., 2017, A serosurvey of greater sage-grouse (Centrocercus urophasianus) in Nevada, USA: Journal of Wildlife Diseases, v. 53, no. 1, p. 136-139.}

DOI: https://doi.org/10.7589/2015-10-285

Background: While information about many threats to GRSG populations is growing, less is known about avian diseases that may affect the species. Testing for the presence of antibodies provides initial information about the previous exposure of birds to infectious diseases.

Objectives: Study objectives were to assess exposure of GRSG in Nevada to eight previously documented diseases and two bacteria affecting birds in this family (Phasianidae).

Methods: Blood samples were collected in 2014 from 31 GRSG (30 male, 1 female) across six leks and tested for the presence of antibodies to eight viruses and two bacteria.

Location: central and northern Nevada; MZ III, MZ IV

Findings: Researchers found antibodies to avian influenza virus, three subtypes of avian leukosis virus, and Pasteurella multocida (the causative agent of avian cholera). No antibodies were detected for infectious bronchitis virus, infectious bursal disease virus, reticuloendothelial virus, West Nile virus, or Salmonella enterica.

Implications: This study represents the first documentation of GRSG exposure to avian influenza virus and may indicate potential for exposure between waterfowl and GRSG in the Great Basin. It is also the first record of sage-grouse exposure to avian leukosis virus subtype J, a more virulent subtype that causes abnormal tissue growths and reproductive problems in poultry. Pasteurella multocida causes septicemic (bloodstream) and respiratory disease. The small sample size, potential for false positives, and small geographic range of the study warrant caution in interpreting results broadly. Broader and longer-term studies would provide insight into disease incidence and its potential effects on GRSG populations.

Topics: other 


\section{*2019 Update* Smith, I.T., Rachlow, J.L., Svancara, L.K., McMahon, L.A., and Knetter, S.J., 2019, Habitat specialists as conservation umbrellas: Do areas managed for greater sage- grouse also protect pygmy rabbits?: Ecosphere, v. 10, no. 8, e02827, p. 1-24.}

DOI: https://doi.org/10.1002/ecs2.2827

Background: Many wildlife species are vulnerable to loss of sagebrush habitat. It has been suggested that GRSG may function as an umbrella species and that by preserving GRSG habitat, many other sagebrush-associated wildlife species will also benefit. Thousands of square kilometers have been designated as GRSG Habitat Management Areas, or HMAs. It is unknown whether HMA designation will benefit other species of conservation concern, such as pygmy rabbits.

Objectives: The authors' goal was to assess the extent to which GRSG HMAs could benefit pygmy rabbits by providing a conservation umbrella.

Methods: Pygmy rabbit occurrence records were compiled and used to delineate a minimum occupied area and to create a species distribution model for pygmy rabbits. The authors then quantified the area of overlap between HMAs and pygmy rabbit minimum occupied areas and suitable habitats for pygmy rabbits.

Location: California, Colorado, Idaho, Montana, Nevada, Oregon, Utah, Wyoming; MZ II, MZ III, MZ IV, MZ V, MZ VII

Findings: Ninety-two percent of the pygmy rabbit minimum occupied area is within GRSG HMAs. The vast majority, 87-91 percent, of pygmy rabbit suitable and primary habitat is also contained within HMAs.

Implications: HMAs have the potential to provide conservation benefits for pygmy rabbits based on habitat overlap. Thus, GRSG could potentially function as an umbrella species, providing benefits for pygmy rabbit conservation if sagebrush habitat within HMAs is retained.

Topics: broad-scale habitat characteristics, new geospatial data 


\section{Smith, J.A., and Dwyer, J.F., 2016, Avian interactions with renewable energy infrastructure- An update: The Condor, v. 118, no. 2, p. 411-423. \\ DOI: https://doi.org/10.1650/CONDOR-15-61.1}

Background: Renewable energy development has increased in the United States and is expected to continue growing. Some direct effects of renewable energy development, such as collisions with wind turbines, are well known. Fewer studies have examined indirect effects of renewable energy development on birds or the mechanisms underlying such effects.

Objectives: Study objectives were (1) to review recent peer-reviewed research related to potential direct and indirect effects on birds of utility-scale onshore wind and solar energy facilities and associated transmission lines, (2) to use the findings to inform renewable energy siting guidelines, and (3) to highlight knowledge gaps and areas for future research.

Methods: The authors used Web of Science to search for peer-reviewed research on the empirical effects of renewable energy infrastructure on birds. Most papers cited were published since 2007.

Location: The geographic range of the literature search was global.

Findings: Direct effects of wind turbines (avian collisions) vary with landscape siting, weather, design (height, diameter, lighting, type of infrastructure), and species. Indirect effects include displacement and changes in survival, breeding performance, and behavior, potentially due to altered predation risk, anthropogenic noise, and habitat loss. Previous studies on GRSG have documented both negative effects of wind turbines on nest survival and a lack of effects on female survival. Direct effects of solar facilities on birds (collision, exposure to concentrated heat) appear to vary with facility design. Indirect effects of solar facilities may include changes in species diversity and abundance. Energy transmission lines appear to affect birds primarily through direct collisions, often near aquatic habitats. Indirect effects of transmission lines may include increased predation by corvids and raptors.

Implications: The authors suggest that siting guidelines be developed in light of each specific geographic context and the vulnerable species present. Recommendations include avoiding areas with high endemism, biodiversity, or ecological sensitivity; rare or sensitive species; high bird use; and certain topographic features that promote foraging or are used during migration. Recommendations also included identifying buffer distances, designing facilities to minimize effects, and stopping operations in some weather conditions. Further research into direct effects, indirect effects, and mechanisms underlying indirect effects across geographies and infrastructure types, as well as their effect distances, is needed to inform conservation efforts.

Topics: behavior or demographics, broad-scale habitat characteristics, energy development, infrastructure (roads, pipelines, powerlines, cell towers), survival 


\title{
Smith, J.T., Evans, J.S., Martin, B.H., Baruch-Mordo, S., Kiesecker, J.M., and Naugle, D.E., 2016, Reducing cultivation risk for at-risk species-Predicting outcomes of conservation easements for sage-grouse: Biological Conservation, v. 201, p. 10-19.
}

\author{
DOI: https://doi.org/10.1016/j.biocon.2016.06.006
}

Background: Large areas of sagebrush have been converted to cropland, particularly in areas of deeper, higher quality soils in the eastern portion of the GRSG range. Cropland conversion threatens GRSG in portions of their range, but the spatial scale of its effects are poorly studied. Conservation easements are one tool to prevent cropland conversion while also providing economic incentives to landowners, but they may be costly to implement on a large scale.

Objectives: Study objectives were to identify (1) the spatial scale of cropland effects on GRSG breeding habitat use, (2) the location and proportion of the GRSG breeding population at risk of local extirpation from future agricultural conversion, and (3) the extent to which targeted conservation easements might affect GRSG populations over the long term.

Methods: The authors used 1,064 observations of active leks between 2008 and 2012 to model the point intensity of active leks in relation to land cover, topography, climate, development, and cropland variables. The proportion of the landscape in cropland was assessed at five spatial scales between 0.8 and 10 kilometers $(\mathrm{km})$. Cropland suitability models were used to develop two scenarios of future cropland conversion. Two scenarios for targeting \$100 million in easements were considered: parcel-level targeting only and a scenario of targeting at both landscape and parcel levels (landscape + parcel).

Location: eastern Montana, northeastern Wyoming, western North Dakota, western South Dakota; MZ I

Findings: Density of active leks declined with increasing proportion of cropland within $3.2 \mathrm{~km}$. Even small incursions of cropland at this scale had strong negative effects on density of active leks. A portion (7.6 percent) of the current GRSG population occurs in areas with less habitat than was considered suitable for lek persistence. A 50 percent increase in cropland area was associated with an additional 5.7 percent of the breeding population falling below the habitat suitability threshold. Easement targeting at parcel and landscape + parcel scales decreased this proportion to 2.6 percent and 1.1 percent, respectively.

Implications: Using information on biological value, conversion risk, and acquisition cost at parcel and landscape scales, authors found that an investment of $\$ 100$ million in conservation easements could reduce potential future conversion of GRSG habitat by 80 percent. Authors highlighted the broad spatial scale of effects of agricultural conversion and suggested that future conservation easements be located to protect large sagebrush landscapes with little or no existing cropland.

Topics: agricultural conversion, behavior or demographics, broad-scale habitat characteristics, effect distances or spatial scale, habitat selection, infrastructure (roads, pipelines, powerlines, cell towers), new geospatial data, population estimates or targets, weather and climate 
*2019 Update* Smith, J.T., Tack, J.D., Berkeley, L.I., Szczypinski, M., and Naugle, D.E., 2018, Effects of livestock grazing on nesting sage-grouse in central Montana: Journal of Wildlife Management, v. 82, no. 7, p. 1503-1515.

DOI: https://doi.org/10.1002/jwmg.21500

Background: There are many hypothesized negative relationships between cattle grazing and GRSG population declines. Many of these hypotheses have yet to be quantitatively assessed.

Objectives: The goal of this study was to evaluate which habitat- and grazing-related variables predict GRSG nest site selection and ness success at local- and pasture-scales.

Methods: Female GRSG were tracked and nest sites were located and monitored to document habitat conditions of nest sites and whether nests were successful. Vegetation, grazing, and human use variables were quantified and compared at nest sites and random locations.

Location: Montana; MZ I

Findings: There was some evidence that nest success was related to senesced vegetation height, but little evidence for negative effects of cattle grazing on nest survival. Instead, nest failures were associated with heavy precipitation over five-day time scales. Female GRSG selected for nest sites with high sagebrush cover that were greater distances from roads.

Implications: The authors suggest that conservation of shrub cover and preventing additional habitat fragmentation by roads would benefit GRSG nesting habitat and nest success.

Topics: behavior or demographics, effect distances or spatial scale, habitat selection, herbivory/grazing, infrastructure (roads, pipelines, powerlines, cell towers), site-scale habitat characteristics, survival, weather and climate 
*2019 Update* Smith, J.T., Tack, J.D., Berkeley, L.I., Szczypinski, M., and Naugle, D.E., 2018, Effects of rotational grazing management on nesting greater sage-grouse: Journal of Wildlife Management, v. 82, no. 1, p. 103-112.

DOI: https://doi.org/10.1002/jwmg.21344

Background: Sagebrush habitats throughout western North America are commonly grazed by cattle and other domestic livestock. There are concerns about potential negative effects of cattle grazing on GRSG habitats and population trends. Many different grazing management strategies have been proposed or implemented to modify or reduce grazing impacts on habitats and wildlife populations. One such management strategy is rotational grazing.

Objectives: The goal of this study was to assess how rotational grazing management strategies influence GRSG nesting habitat in central Montana.

Methods: Over six years, the authors monitored almost 500 GRSG nests in areas managed with rotational grazing or various other grazing strategies as well as areas that were rested from grazing. Vegetation structure and survival of GRSG nests were quantified.

Location: Montana; MZ I

Findings: There was only weak evidence that rotational grazing lead to greater daily survival rates for GRSG nests. Rest from grazing did not increase daily survival rates. Neither grazing strategy resulted in substantial changes to herbaceous vegetation height or cover.

Implications: The authors suggest that GRSG nest survival is not strongly influenced by grass height and the importance of hiding cover may be currently overemphasized. Instead, they suggest that quality GRSG nesting habitat may be achieved through grazing management strategies that focus on range health principles.

Topics: behavior or demographics, habitat selection, herbivory/grazing, human dimensions or economics, site-scale habitat characteristics, survival 


\section{Smith, J.T., Tack, J.D., Berkeley, L.I., Szczypinski, M., and Naugle, D.E., 2017, Effects of rotational grazing management on nesting greater sage-grouse: Journal of Wildlife Management, v. 82, no. 1, p. 103-112.}

DOI: https://doi.org/10.1002/jwmg.21344

Background: Livestock grazing is widespread across the sagebrush biome and has been suggested as a contributing factor in GRSG declines. Grazing is believed to affect nest success through increased nest abandonment from livestock disturbance and reduced nest concealment. Rotational grazing systems may help to maintain tall herbaceous vegetation in GRSG nesting areas.

Objectives: Study objectives were to assess the potential effects of rotational grazing and rest from grazing on (1) GRSG nest survival and (2) vegetation structure.

Methods: The authors monitored 501 nests between 2011 and 2016 across 10 ranches that had recently implemented rotational grazing, 9 of which incorporated periods of $\geq 12$ months of rest from grazing, and $>20$ ranches practicing traditional grazing. Researchers developed Bayesian models of nest survival considering nest and grazing system variables. Researchers quantified vegetation structure in both grazing system types and at a smaller number of idled areas (that is, areas not grazed for $4-12$ years).

\section{Location: central Montana; MZ I}

Findings: Nest survival was slightly higher on ranches using rotational rather than traditional grazing, but the effect of rotational grazing was not statistically supported. Live and senesced grass height and litter were also higher on ranches using rotational grazing, but effect sizes were small compared to annual variation. Bare ground, herbaceous cover, and visual obstruction did not differ between grazing strategies. When comparing grazed lands to idled areas, only visual obstruction was higher on idled lands.

Implications: The authors suggest that grazing management likely has a minor influence on nest survival compared to factors such as weather and predators and that observed nest survival rates are unlikely to be limiting population growth in the study area. Most vegetation metrics on grazed lands were within one standard deviation of values on long-term idled lands, suggesting that vegetation similar to that on idled lands is likely abundant on grazed lands. The authors suggest caution in extrapolating results to other areas because of different vegetation communities and precipitation regimes.

Topics: behavior or demographics, broad-scale habitat characteristics, herbivory/grazing, sitescale habitat characteristics 


\section{Smith, J.T., Tack, J.D., Doherty, K.E., Allred, B.W., Maestas, J.D., Berkeley, L.I., Dettenmaier, S.J., Messmer, T.A., and Naugle, D.E., 2018, Phenology largely explains taller grass at successful nests in greater sage-grouse: Ecology and Evolution, v. 8, p. 356-364.}

DOI: https://doi.org/10.1002/ece3.3679

Background: Nest success rates are an important component of population demographics, and height of grasses around nesting sites has been described as contributing to GRSG nesting success. However, changes in grass stature during nesting and between sampling periods may have contributed to observed differences, leading to erroneous conclusions.

Objectives: The authors' objective was to test an existing hypothesis and previous results that suggested a positive causal relation between nest survival and the height of grasses around the nest site.

Methods: The authors re-analyzed data from four previous studies, adjusting height estimates of grasses to account for changes in grass height caused by the passing of time and continuing growth. They compared nest success rates (1,204 nests observed over 24 years) derived from nest observations of successful and unsuccessful nests and used adjusted grass heights to remove phenological effects created by differences in timing of vegetation measurements.

Location: Montana, Utah, and Wyoming; MZ I, MZ II

Findings: Adjusting grass height measurements in order to standardize estimates to a common phenological frame corrected for a common trend of increasing height over time in the data. When using a less biased estimator of vegetation (corrected grass height), there was no evidence supporting a difference in grass height between successful and unsuccessful GRSG nests. Nest survival analyses, when corrected for predicted hatch date, provided mixed support for a relation between survival and grass height.

Implications: The available evidence for a causal relation between grass height and nest success was weak, although grass height remained positively correlated with nest survival in the Powder River Basin of Wyoming after correction. Variations in results suggested that taller grass may be beneficial to nest survival in some circumstances (such as where shrub cover is low), but this explanation was not supported by the data analyzed here. Nest site selection or other life stages (for example, brood survival) may be affected by the structure of grasses. The authors suggested that findings from previous studies may have led to an overemphasis of the role of grass height in GRSG nesting habitat quality.

Topics: behavior or demographics, site-scale habitat characteristics 


\section{Smith, K.T., and Beck, J.L., 2017, Sagebrush treatments influence annual population change for greater sage-grouse: Restoration Ecology, Early View article posted September 15, 2017, $9 \mathrm{p}$.}

DOI: https://doi.org/10.1111/rec.12589

Background: Big sagebrush communities across the West have been treated to restore their herbaceous understories in an effort to improve habitat conditions for GRSG, but there is little information on how such treatments translate to changes in GRSG populations.

Objectives: Study objectives were to investigate how three aspects of sagebrush treatment relate to annual changes in male GRSG populations: (1) area of sagebrush treated, (2) type of treatment, and (3) time since treatment.

Methods: The authors quantified annual changes in male GRSG populations using surveys of more than 900 leks conducted from 1995 to 2012 in areas of big sagebrush that had been treated chemically, mechanically, or by using prescribed fire between 1994 and 2012. Treatment area was quantified at six spatial scales between 1 and 10 kilometers $(\mathrm{km})$ around leks, and time lags of $1,3,5$, and 10 years were considered. Oil and gas well-pad density, wildfires, and monthly and seasonal precipitation were also considered in models.

Location: Wyoming; MZ II

Findings: Treatments were either unrelated or negatively related to annual change in male GRSG population with a single exception: a positive relation with chemical treatments after 11 years (10-year time lag) at the $10-\mathrm{km}$ scale. Population change was consistently negatively correlated with well density and wildfire; correlations between population change and precipitation varied in direction with the timing of precipitation and time lag considered.

Implications: Results suggest that habitat treatments in Wyoming big sagebrush should be approached cautiously (or not at all), though there is some indication that chemical treatments, which can retain shrub cover, may be beneficial over longer time periods. The authors noted that the majority of treatment areas in the study were small (less than 2 square kilometers), that the response period was relatively short given sagebrush recovery rates, and that they were unable to incorporate post-treatment grazing pressure into the study.

Topics: behavior or demographics, broad-scale habitat characteristics, effect distances or spatial scale, energy development, fire or fuel breaks, habitat restoration or reclamation, population estimates or targets, sagebrush removal, weather and climate 


\section{*2019 Update* Smith, K.T., Beck, J.L., and Kirol, C.P., 2018, Reproductive state leads to intraspecific habitat partitioning and survival differences in greater sage-grouse: implications for conservation: Wildlife Research, v. 45, no. 2, p. 119-131.}

DOI: https://doi.org/10.1071/WR17123

Background: Individuals of the same species may use different habitats or use habitats during different times in what is known as "intraspecific habitat partitioning." Learning how individual female GRSG partition habitat based on reproductive status may help inform management decisions.

Objectives: The goal of the study was to determine whether and how female GRSG of different reproductive states exhibit habitat partitioning behaviors.

Methods: The authors compared habitats used by brood-rearing GRSG to those used by broodless females. They further assessed the extent to which brood-rearing investments and habitat choice influenced female survival.

Location: Wyoming; MZ II

Findings: Habitat partitioning between broodless and brood-rearing female GRSG was evident at both micro- and macro-scales, with brood-rearing females selecting for greater forb richness and broodless females selecting for greater overall vegetation cover. Summer survival rates were greater for broodless females.

Implications: The authors suggest that habitat partitioning by brood-rearing and broodless female GRSG is a mechanism by which females can maximize their survival probabilities and that conserving habitats used by each type of female is important for persistence of GRSG populations.

Topics: behavior or demographics, habitat selection, population estimates or targets, site-scale habitat characteristics, survival 


\section{Smith, K.T., Beck, J.L., and Pratt, A.C., 2016, Does Wyoming's core area policy protect winter habitats for greater sage-grouse?: Environmental Management, v. 58, no. 4, p. 585- 596.}

DOI: https://doi.org/10.1007/s00267-016-0745-8

Background: Wyoming's Sage-Grouse Core Area policy was intended to protect important GRSG breeding habitat, but protected areas must protect all seasonal habitats to effectively maintain populations.

Objectives: Study objectives were to identify (1) the timing of GRSG use of winter habitats relative to current winter seasonal stipulations, (2) to what extent GRSG breeding in identified core areas used winter habitats, and (3) how the amount and pattern of GRSG winter habitats relate to identified core areas.

Methods: The authors collected GPS data from 72 female GRSG in two study areas from 2011 to 2015. Land cover, vegetation, topography, and anthropogenic disturbance variables summarized at six spatial scales between 0.1 and 3.2 kilometers $(\mathrm{km})$ were used to model winter habitat.

Location: central and north-central Wyoming; MZ II

Findings: Winter habitat use varied slightly between the two study areas, beginning in early to late October and ending March 21. For GRSG nesting in core areas, 62-98 percent of winter GRSG locations were also within the core areas. Top models for winter GRSG habitat included land cover, topography, and disturbance variables assessed at spatial scales from $0.1 \mathrm{~km}$ to $2 \mathrm{~km}$. However, only two variables had coefficients with confidence intervals that did not overlap zero- the proportion of big sagebrush was positively related to winter habitat use, and slope was negatively related to winter habitat use. Of the frequently selected winter habitats in one of the two study areas, 70 percent were outside of identified core areas.

Implications: Current seasonal use restrictions in winter concentration areas (December 1 to March 15) are shorter than the GRSG winter habitat use period identified in the study. A substantial proportion of winter use areas were located outside of identified core areas in one of the two study areas, suggesting reconsideration of the ability of Wyoming's Core Area policy to provide for long-term conservation of GRSG.

Topics: behavior or demographics, broad-scale habitat characteristics, effect distances or spatial scale, habitat selection, infrastructure (roads, pipelines, powerlines, cell towers), new geospatial data 
*2019 Update* Smith, K.T., Dinkins, J.B., and Beck, J.L., 2019, Approaches to delineate Greater Sage-grouse winter concentration areas: The Journal of Wildlife Management, $v$. 83, no. 7, p. 1495-1507.

DOI: https://doi.org/10.1002/jwmg.21738

Background: Understanding each seasonal habitat need of GRSG is important for their conservation. Protected areas, known as Priority Areas of conservation (PACs), have been designated for GRSG based on known breeding season habitat needs. However, there is a need to understand and protect GRSG winter concentration areas (WCAs), areas where more than 50 individuals congregate during the winter.

Objectives: The authors' goal was to identify areas used by GRSG during the winter and to quantify winter habitat selection in order to evaluate protected area suitability.

Methods: Aerial infrared videography was used to locate 4,859 wintering individuals in 132 flocks. The authors used individual-based resource selection functions to quantify habitat selection of these birds. Habitat and use were compared inside and outside of PAC Core Areas.

Location: Wyoming; MZ I, MZ II

Findings: GRSG individuals and flocks were located within PAC Core Areas often, however an important proportion of birds used habitats outside of the Core Areas. Shrub height, sagebrush landcover, distance to leks, GRSG population density, and energy development density were important for winter habitat selection. Models developed at the individual- and WCA-levels produced similar results.

Implications: The authors suggest that individual-based resource selection function models can be useful when data on flock sizes are not available. They also suggest that their survey and modeling approach was constructive for identifying habitat selection and determining whether currently protected areas are adequate for all seasons of use by GRSG. They conclude that an important amount of GRSG winter habitat might not be adequately protected by PAC Core Areas in Wyoming.

Topics: broad-scale habitat characteristics, effect distances or spatial scale, energy development, habitat selection, new geospatial data 


\section{*2019 Update* Smith, K.T., Forbey, J.S., and Beck, J.L., 2018, Effects of mowing and tebuthiuron on the nutritional quality of Wyoming big sagebrush: Rangeland Ecology \& Management, v. 71, no. 4, p. 417-423.}

DOI: https://doi.org/10.1016/j.rama.2018.02.006

Background: Wyoming big sagebrush has been manipulated by mowing and herbicide treatments in order to increase habitat quality for species such as GRSG. Many studies have documented the effects of these treatments on the structural characteristics of sagebrush and sagebrush habitats, but little is known about how these treatments influence the nutritional quality of sagebrush plants, which GRSG rely upon as a winter food source.

Objectives: The authors sought to quantify the effects of mowing and herbicide application on the nutritional quality of Wyoming big sagebrush plants.

Methods: After mowing and applying tebuthiuron herbicide, samples of sagebrush were collected in treated and control areas. Samples were analyzed for crude protein and plant secondary metabolites, which past studies have shown to influence GRSG foraging choices.

Location: Wyoming; MZ II

Findings: Shortly after treatment, there was some evidence for slight increases in crude protein and no changes in plant secondary metabolites.

Implications: The authors suggest that although these treatments may not negatively impact the nutritional qualities measured, the loss of sagebrush leaf biomass as forage is likely to result in little treatment benefit for GRSG.

Topics: habitat restoration or reclamation, sagebrush removal, site-scale habitat characteristics 
*2019 Update* Smith, K.T., LeVan, J.R., and Beck, J.L., 2019, Forb and invertebrate response to treatments for greater sage-grouse in Wyoming big sagebrush: Rangeland Ecology \& Management, v. 72, n. 5, p. 791-795.

DOI: https://doi.org/10.1016/j.rama.2019.05.002

Background: Treatments in sagebrush communities are frequently implemented with the intent to benefit GRSG through increasing forb and invertebrate availability. However, information on the response of forbs to these treatments is often conflicting and little information exists regarding invertebrate responses.

Objectives: The goal of the study was to assess the effects of mowing and tebuthiuron herbicide treatment on forbs and invertebrates and compare forb and invertebrate biomass in treated plots to biomass values from areas used by brood-rearing female GRSG.

Methods: Forb and invertebrate biomass in treated areas were compared to biomass values in untreated reference areas and locations used for brood-rearing.

Location: Wyoming; MZ II

Findings: Mowing and herbicide treatments did affect forb and invertebrate biomass relative to values from untreated reference plots for up to four years post-treatment. Biomass values were less than or equal to values observed in brood-rearing locations within two years post-treatment.

Implications: The authors state that these results concur with other studies, suggesting that mowing and herbicide treatments aimed at increasing forb and invertebrate food resources by reducing Wyoming big sagebrush may not benefit GRSG.

Topics: habitat restoration or reclamation, habitat selection, sagebrush removal, site-scale habitat characteristics 
*2019 Update* Smith, K.T., Pratt, A.C, and LeVan, J.R., Rhea, A.M., and Beck, J.L., 2019, Reconstructing greater sage-grouse chick diets: diet selection, body condition, and food availability at brood-rearing sites: The Condor: Ornithological Applications, v. 121, no. 1, p. 1-12.

DOI: https://doi.org/10.1093/condor/duy012

Background: GRSG chicks consume forbs and invertebrates during brood-rearing season. Consequently, these resources are important for chick survival and population viability in the long-term. However, little is known about how different diets lead to different body conditions for GRSG chicks.

Objectives: The goal of this study was to determine if female GRSG select brood-rearing habitats based on the potential for high quality diets for their chicks and how different diets affect chick body condition.

Methods: The authors quantified chicks' diets using field methods and stable isotope analysis. Chick body condition metrics were then related to dietary consumption.

Location: Wyoming; MZ II

Findings: Brood-rearing female GRSG selected habitats with food resources that were proportional to their availability, except for four weeks post-hatch when they selected for locations with greater forb abundance. Chick diet assimilation was not related to availability of forbs and invertebrates at brood-rearing locations. Chicks consumed forbs increasingly with age, and those that consumed greater amounts of plants within the first week of life tended to exhibit increased body condition.

Implications: The authors suggest that conserving functioning sagebrush ecosystems, including brood-rearing habitats with abundant forb and invertebrate resources for chick survival should be a management goal. They suggest that further research is needed to determine whether treating sagebrush communities with the intent of improving GRSG habitat actually results in benefits to GRSG.

Topics: behavior or demographics, habitat selection, site-scale habitat characteristics, survival 


\section{Spence, E.S., Beck, J.L., and Gregory, A.J., 2017, Probability of lek collapse is lower inside sage-grouse core areas-Effectiveness of conservation policy for a landscape species: PLoS ONE, v. 12, no. 11, article e0185885, 15 p.}

DOI: https://doi.org/10.1371/journal.pone.0185885

Background: The 2015 decision that listing of GRSG under the Endangered Species Act of 1973 was not warranted was made in part because of actions taken by States to address potential threats to GRSG on State and private lands. Wyoming harbors a significant portion of the GRSG population and has implemented policy to protect distinct "core areas" for GRSG by limiting the timing and amount of anthropogenic disturbance within those areas. There is now a need to assess the effects of this policy on GRSG populations.

Objectives: Study objectives were to identify (1) the proportion of the GRSG population contained within core areas, (2) whether leks in core areas have a lower probability of collapse, and (3) the potential effects of oil and gas development adjacent to core areas on GRSG populations within core areas.

Methods: The authors used annual lek counts from 1999 to 2013 to develop a lek collapse metric (defined as zero birds observed at a lek for 3 consecutive years). The average probability of lek collapse was calculated for four regions within the core area-(1) all leks inside the core area, (2) only those leks within 1.6 kilometers $(\mathrm{km})$ of the core area boundary, (3) only those leks located within $4.8 \mathrm{~km}$ of the core area boundary, and (4) only those leks at least $4.8 \mathrm{~km}$ inside of the core area boundary. Probably of lek collapse was then related to the density of oil and gas wells outside of core areas (within $1.6 \mathrm{~km}$ and $4.8 \mathrm{~km}$ of the core area boundary).

Location: Wyoming; MZ I, MZ II

Findings: From 1999 to 2013, core areas contained about 66 percent of GRSG leks and 83 percent of male GRSG attending leks. The probability of lek collapse was nearly double outside the core areas versus inside them. The probability of lek collapse inside core areas was positively related to the density of oil and gas wells located outside of core areas at two distances - within $1.6 \mathrm{~km}$ and within $4.8 \mathrm{~km}$ of the core area boundary.

Implications: The proportion of the male population within core areas and the observed decreased probability of lek collapse within core areas suggest that the core area policy is providing broad protection for GRSG in Wyoming. However, limitations on development near core areas may be needed to more effectively protect GRSG populations within core areas.

Topics: behavior or demographics, broad-scale habitat characteristics, effect distances or spatial scale, energy development, new geospatial data 
*2019 Update* Steenvoorden, J., Meddens, A.J.H., Martinez, A.J., Foster, L.J., and Kissling, W.D., 2019, The potential importance of unburned islands as refugia for the persistence of wildlife species in fire-prone ecosystems: Ecology and Evolution, DOI: 10.1002/ece3.5432.

DOI: https://doi.org/10.1002/ece3.5432

Background: Unburned islands might provide refugia to wildlife in fire-prone ecosystems and may therefore help to mitigate the negative effects of wildfire on wildlife populations. However, the role of unburned islands as potential refugia to GRSG and their effects on population dynamics is poorly understood.

Objectives: The objective was to determine if unburned islands help sustain GRSG populations by analyzing temporal trends in male GRSG attendance of lek sites in relation to areas with and without fire disturbance.

Methods: Fire perimeters and unburned islands were determined using the Monitoring Trends in Burn Severity database and a derived unburned island database, respectively, for the years 1984 - 2014. Population trends in male lek attendance were analyzed for pre- and post-fire conditions using lek count data from 39 leks gathered between 1984 - 2017. Leks were categorized based on their proximity to burned areas as being either within unburned islands, fire perimeters, a small buffer of the fire perimeter, or a larger buffer of the fire perimeter. The effect of postfire habitat composition - vegetation height, cheatgrass cover, and elevation - on population trends was also analyzed for 32 of the leks.

Location: Oregon; MZ IV, MZ V

Findings: Male lek attendance was not significantly different within unburned islands after a fire but was significantly lower within fire perimeters. Male lek attendance after a fire was lower within a small buffer of the fire perimeter, but not significantly. Within a large buffer of the fire perimeter, male lek attendance remained stable. Analysis of post-fire habitat composition revealed that taller sagebrush and higher elevations had a positive influence on GRSG populations, whereas cheatgrass had a negative impact.

Implications: Population at leks located within fire perimeters are negatively impacted. Unburned islands play an important role as refugia and maintaining unburned vegetation may be vital for the success of GRSG populations after a wildfire event. The recovery of natural vegetation post-fire may also benefit GRSG populations.

Topics: behavior or demographics, broad-scale habitat characteristics, effect distances or spatial scale, fire or fuel breaks, habitat restoration or reclamation, habitat selection, population estimates or targets, site-scale habitat characteristics 


\section{Stonehouse, K.F., Shipley, L.A., Lowe, J., Atamian, M.T., Swanson, M.E., and Schroeder, M.A., 2015, Habitat selection and use by sympatric, translocated greater sage-grouse and Columbian sharp-tailed grouse: Journal of Wildlife Management, v. 79, no. 8, p. 1308- 1326.}

DOI: https://doi.org/10.1002/jwmg.990

Background: Given the large reductions in available sagebrush habitat that have occurred, it is important to understand how species with different life history characteristics coexist within remaining habitat areas.

Objectives: Study objectives were to identify how habitat selection by GRSG and Columbian sharp-tailed grouse differs (1) in spring and summer home ranges and (2) at nesting sites where they co-occur in eastern Washington.

Methods: One hundred and seventy-one translocated GRSG and 150 translocated Columbian sharp-tailed grouse were tagged and monitored, primarily during 2010-2012. Locational data were available for a minimum of between 26 and 53 birds of each species for individual analyses in this study. Habitat and nest site selection were modeled based on vegetation, land use, topography, and anthropogenic disturbance variables assessed at spatial scales from 10 to 250 meters. A suite of vegetation characteristics were also measured at nest sites and associated nonnest sites.

\section{Location: eastern Washington; MZ VI}

Findings: GRSG had larger spring home ranges than Columbian sharp-tailed grouse, with the home ranges of the latter largely contained within the composite of the GRSG home ranges. Within spring and summer home ranges, both species used restored fields and areas farther from trees, roads, and power lines. Across the landscape, GRSG tended to select nest sites farther from power lines. Compared to Columbian sharp-tailed grouse, GRSG selected nest sites in restored fields less often and selected sites with greater shrub cover, with higher patch diversity, and farther from power lines. At the site scale, GRSG tended to select nest sites with greater cover of shrubs and annual forbs and taller perennial grasses than occurred at comparable non-nest sites.

Implications: The authors suggest that managing for an array of shrub densities within sagebrush ecosystems can provide suitable habitat for both grouse species and that restoration of former croplands can increase available habitat for both species, particularly when restorations include sagebrush and when native forbs and are located within a matrix of sagebrush. Removal of unused power lines and poles may benefit both grouse species over the long term.

Topics: agricultural conversion, behavior or demographics, broad-scale habitat characteristics, effect distances or spatial scale, habitat restoration or reclamation, habitat selection, infrastructure (roads, pipelines, powerlines, cell towers), new geospatial data, site-scale habitat characteristics, translocation 


\section{*2019 Update* Sutphin, A.L., Maechtle, T.L., Kirol, C.P., and Fedy, B.C., 2018, A mobile tool for capturing greater sage-grouse: Wildlife Society Bulletin, v. 42, no. 3, p. 504-509.}

DOI: https://doi.org/10.1002/wsb.899

Background: Traditional methods of trapping GRSG, such as drop-netting and spotlighting, are largely ineffective in areas of low population density. Current methods often also present logistical challenges and may harm GRSG in the process. New methods of capture are needed to increase trapping success and reduce danger to GRSG.

Objectives: The objective was to develop a new method of capturing GRSG that would be safer and more effective than current methods for populations that are small or located in patchy habitats.

Methods: Overall, 115 capture attempts of females in the Powder River, Wyoming GRSG population were conducted in spring and late summer/autumn between 2008 - 2011. A CODA Net Launcher was used and was propelled via a blank .308-caliber rifle cartridge using expanding gas. It was used both as a stationary device and mounted to an all-terrain vehicle for mobile deployment. At times, a herder was also used to increase the likelihood of capturing GRSG. Individuals were monitored for four weeks after capture.

Location: Wyoming; MZ I, MZ II

Findings: Capture rates were high, 71 percent, and did not vary significantly by season or time of day. Injury associated with capture included the mortality of one individual. During the four weeks after capture, survival of GRSG was also high at 95 percent. Unsuccessful capture attempts were attributed to poor net deployment, dense vegetation, wind, ground slope, repeated capture attempts on the same flock within the same day, and evasion of the net by individuals.

Implications: The authors describe an effective method for capturing GRSG that is easy to set up, logistically feasible, and poses little threat to the safety of GRSG being captured. This method may also be successful when applied to other lekking grouse species.

Topics: other topic, survival 
*2019 Update* Tack, J.D., Jakes, A.F., Jones, P.F., Smith, J.T., Newton, R.E., Martin, B.H., Hebblewhite, M., and Naugle, D.E., 2019, Beyond protected areas: Private lands and public policy anchor intact pathways for multi-species wildlife migration: Biological Conservation, v. 234, p. 18-27.

DOI: https://doi.org/10.1016/j.biocon.2019.03.017

Background: GRSG and pronghorn antelope migrate long distances across the Northern Great Plains. When migratory movements cross international or other land ownership boundaries it can pose a challenge for conservation and management efforts. Identifying multi-species migratory pathways while also considering land ownership, land use, and conservation policy is essential for maintaining functional habitat connectivity.

Objectives: The objectives were to: 1) examine current conservation efforts in maintaining migration pathways for multiple taxa, 2) identify potential migratory pathways for both GRSG and pronghorn in order to set future goals for conservation measures on private lands, and 3) use optimization modelling to create a spatial tool to help prioritize conservation easements.

Methods: Eighteen male and female GRSG were fitted with GPS tracking devices between 2010 -2011 during spring or early autumn. Forty female pronghorns were fitted with GPS devices during the winter between 2009 - 2010. Using GPS locations of individuals that exhibited migration behavior, migratory pathways and temporal trends were estimated for both species. Land tenure was characterized using public databases for the US and Canada, and a spatial tool to prioritize conservation easements was created using a systematic conservation planning approach that focused on lands at risk of future cultivation and multi-species migratory pathway overlap.

Location: Saskatchewan, Montana; MZ I

Findings: GRSG and pronghorn migrations showed spatial overlap and similarity in peak migration dates, durations, and stopover frequency between the two species. Large and intact public and private working lands largely underpinned migration pathways, whereas protected areas only provided another 5 percent of habitat. GRSG policy efforts were beneficial for both species. Core areas provided well targeted protections to sage-grouse migration, particularly with the addition of a connectivity area specific to this population. GRSG core areas extend conservation measures to migratory pronghorn, as over half of pronghorn individual migratory pathways were encompassed by GRSG breeding and connectivity core areas. Geospatial analysis revealed options for conserving $70-90$ percent of migratory pathways for both species through conservation easements on private lands.

Implications: Conserving GRSG migratory pathways may also help facilitate pronghorn migration. Limiting surface disturbance such as energy development on public lands, use of management tools such as fence modification or removal, and optimizing conservation of private lands based on cultivation risk and multi-species overlap are important for sustaining functional connectivity and maintaining migratory pathways.

Topics: agricultural conversion, behavior or demographics, broad-scale habitat characteristics, energy development, ex-urban development, fences, habitat selection, herbivory/grazing, human 
dimensions or economics, infrastructure (roads, pipelines, powerlines, cell towers), new geospatial data 


\section{Taylor, J.D., Holt, R.D., Orning, E.K., and Young, J.K., 2017, Greater sage-grouse nest survival in Northwestern Wyoming: Journal of Wildlife Management, v. 81, no. 7, p. 1219- 1227.}

DOI: https://doi.org/10.1002/jwmg.21296

Background: Low recruitment is one factor limiting GRSG population growth, and both nest and chick survival contribute to recruitment. Predation is the leading cause of GRSG nest failure. Some predators are currently managed for other purposes, such as reducing livestock and big game depredation.

Objectives: Study objectives were (1) to quantify GRSG nest survival and (2) to examine factors influencing GRSG nest survival within an area receiving lethal predator control.

Methods: The authors tagged and monitored 225 female GRSG across five study sites from 2011 to 2014. The authors monitored 204 GRSG nests to identify nest fates and model nest survival and installed motion-sensing cameras to document causes of nest failure. Predator removal was quantified at four study sites; predators were not removed at the fifth study site.

Location: northwestern Wyoming; MZ II

Findings: Coyotes were the primary predator removed from study sites, along with generally smaller numbers of feral cats, raccoons, porcupines, red foxes, and striped skunks. Nest survival differed by site and varied from 0.2 to 0.56 . Coyotes, followed by ravens, were the greatest known causes of nest failure. The site with no predator removal had one of the highest rates of GRSG nest survival in the study.

Implications: The authors suggested that predator removal to reduce livestock and big game depredation is not likely to negatively affect GRSG nest survival, but effects on adult and chick survival are unknown. The authors also suggested that additional research on raven predation of GRSG nests may be warranted. Information on predator abundance and prey base would help to relate GRSG nest survival to local predator-prey dynamics.

Topics: behavior or demographics, predators or predator control 
*2019 Update* Taylor, D.T., Rimbey, N. R., and Tanaka, J.A., 2019, Economic impact of sage grouse management on livestock grazing in the Western United States: Western Economics Forum, v. 17, no. 1, p. 98-114.

DOI: https://doi.org/10.22004/ag.econ.287319

Background: In the U.S., GRSG habitat spans 11 states and encompasses 165 million acres. Because the majority of this area is public land that is also used for livestock grazing, GRSG management may have important economic implications for livestock grazing operations.

Objectives: The objective was to quantify the economic impact that GRSG management has on livestock grazing throughout the western United States in terms of ranch profitability and regional economy.

Methods: Analysis was completed to examine economic impacts on a ranch-level and regionallevel. Ranch-level analysis was completed for four states and based on linear programming models. Regional-level impact was completed on six land-use plans that had similar reporting data and included areas in eight states. Regional-level analysis was based on an IMPLAN model. Six proposed land use plan amendments were also compared.

Location: California, Colorado, Idaho, Montana, Nevada, Oregon, Utah, Wyoming; MZ I, MZ II, MZ III, MZ IV, MZ V, MZ VII

Findings: The authors found a strong economic impact of livestock grazing in the Western U.S. and that reducing grazing on public lands recognized as GRSG habitat would likely negatively impact the economy in western U.S. states at both a ranch-level and regional-level. They also found that eliminating grazing would have even greater negative impacts, as would listing GRSG under the Endangered Species Act.

Implications: Reducing or eliminating livestock grazing on federally protected lands recognized as GRSG habitat could create negative economic impacts on both a ranch-scale and regionalscale and may create increased economic burdens for rural communities in western states.

Topics: herbivory/grazing, human dimensions or economics 


\section{Thompson, T.R., Apa, A.D., Reese, K.P., and Tadvick, K.M., 2015, Captive rearing sage- grouse for augmentation of surrogate wild broods-Evidence for success: Journal of Wildlife Management, v. 79, no. 6, p. 998-1013.}

DOI: https://doi.org/10.1002/jwmg.905

Background: Translocation of adult GRSG is one strategy to stabilize or augment small or declining populations, but translocation efforts have generally been relatively unsuccessful. Another potential strategy is to incubate, hatch, and briefly rear GRSG chicks in captivity and then release them into wild surrogate broods, but the cost, feasibility, and benefits of this strategy have not been well studied.

Objectives: Study objectives were to: 1) develop techniques for collecting GRSG eggs and rearing GRSG chicks in captivity, 2) identify variables influencing hatching and rearing success of GRSG in captivity, and 3) quantify both the adoption and survival of captive-reared chicks placed in surrogate wild broods and the factors influencing chick survival.

Methods: Authors collected 304 GRSG eggs from 2004 to 2007, hatched and reared 175 chicks in captivity to approximately 10 days of age, and monitored 133 chicks transplanted into wild broods until 28 days of age. The authors modeled hatching success, rearing success, and chick survival using study site and multiple egg, chick, female, and brood characteristics.

Location: northwestern Colorado; MZ II

Findings: The authors describe egg collection, storage, hatching, rearing, and adoption techniques. Hatching success of collected eggs was 0.745 and decreased with the number of days an egg was stored and weight loss of the egg after collection. Successful rearing to 10 days was positively related to hatch weight and daily weight gain and negatively related to egg storage time and later hatch dates. Most chicks, 88.7 percent, were adopted into wild broods within a day. A quadratic model best described survival of adopted chicks, with survival decreasing initially and then increasing during days 14-28. Weight at adoption positively influenced survival, whereas later adoption dates negatively influenced survival.

Implications: The authors conclude that egg collection and hatching, rearing, and adoption of captive-raised chicks into wild broods is feasible. The authors observed six cases of depredation and abandonment of nests shortly after egg collection and suggest an alternative strategy for future egg collection.

Topics: behavior or demographics, captive breeding, predators or predator control, survival, translocation 


\section{*2019 Update* Timmer, J.M., Aldridge, C.L., and Fernandez-Gimenez, M.E., 2019, Managing for multiple species-Greater sage-grouse and sagebrush songbirds: The Journal of Wildlife Management, v. 83, no. 5, p. 1043-1057.}

DOI: https://doi.org/10.1002/jwmg.21663

Background: Single-species management of GRSG, as a so-called umbrella species, is often assumed to benefit other sagebrush-associated wildlife. However, this concept has not been rigorously tested at multiple scales, and its actual effectiveness is unknown for songbirds. A greater understanding of these dynamics may help improve conservation of sagebrush ecosystems.

Objectives: The authors sought to determine whether GRSG is an umbrella species for sagebrush-associated songbirds.

Methods: The authors surveyed for GRSG pellets at 300 plots across two study sites from 2013 to 2015. Concurrently, they also surveyed these locations for four songbird species: Brewer's sparrows, green-tailed towhees, sagebrush sparrows, and sage thrashers. They used these data to model GRSG probability of occurrence in comparison with songbird density and species richness. Models were created at $30 \mathrm{~m}, 0.56 \mathrm{~km}, 1 \mathrm{~km}$, and $5 \mathrm{~km}$ spatial scales.

Location: Colorado; MZ II

Findings: Probability of GRSG occurrence was significantly correlated with density for three songbird species. It was negatively correlated with sagebrush sparrows, which use habitat with less sagebrush and ground cover than GRSG. Richness of three songbird species was positively associated with areas of high GRSG occurrence probability. In contrast, lower songbird species richness was associated with areas of low GRSG occurrence probability.

Implications: At these spatial scales, GRSG may be an effective umbrella species for three of the four songbird species due to similar habitat requirements. However, the authors argued that managing for a small number of focal species, rather than one umbrella species, may be more effective when such species have different or conflicting habitat requirements. This may be accomplished by promoting habitat heterogeneity across multiple scales.

Topics: broad-scale habitat characteristics, effect distances or spatial scale, site-scale habitat characteristics 
Van Lanen, N.J., Green, A.W., Gorman, T.R., Quattrini, L.A., and Pavlacky, D.C., Jr., 2017, Evaluating efficacy of fence markers in reducing greater sage-grouse collisions with fencing: Biological Conservation, v. 213, p. 70-83.

DOI: https://doi.org/10.1016/j.biocon.2017.06.030

Background: GRSG are susceptible to collisions with fences, and wildlife managers often install fence markers in an effort to reduce such collisions. However, there is little information available on the efficacy of different fence markers.

Objectives: Study objectives were (1) to evaluate the effectiveness of different fence markers in reducing GRSG collisions, (2) to estimate the effect of local and landscape factors on collision risk, and (3) to evaluate an existing GRSG collision risk model that was based on terrain ruggedness and distance to leks.

Methods: The authors conducted an experiment by installing three fence markers (white, white with reflective tape, FlySafe) and a control (no marker) in 26 different lek areas and conducting collision surveys in the spring of 2014 and 2015. Lek, survey, fence, marker, and weather variables were used to develop a multiscale occupancy model.

Location: southwestern Wyoming; MZ II

Findings: Use of fence markers substantially reduced collisions, but there was little difference between marker types. Lower collision probabilities were associated with wooden fence posts and fences farther from leks, with a smaller reduction associated with fences that were similar in height to the associated woody vegetation. The study found only a slightly elevated collision probability between high-risk and moderate-risk areas identified by the existing collision risk model (low-risk areas were not examined).

Implications: The authors suggest installing some type of fence marker when fencing is required, especially when fencing is exposed above existing woody vegetation and located near leks.

Topics: behavior or demographics, effect distances or spatial scale, fences, weather and climate 


\section{Walker, B.L., Apa, A.D., and Eichhoff, K., 2016, Mapping and prioritizing seasonal habitats for greater sage-grouse in Northwestern Colorado: Journal of Wildlife Management, v. 80, no. 1, p. 63-77. \\ DOI: https://doi.org/10.1002/jwmg.962}

Background: Accurate maps of seasonal habitats are needed to inform conservation and management actions. Analyses that identify the spatial scale at which species may respond to landscape features can further inform management, particularly when some land uses may conflict with species conservation needs.

Objectives: Study objectives were (1) to develop models and maps of seasonal habitat, (2) to identify the spatial scales at which vegetation and topography most strongly relate to habitat selection, and (3) to map the proportion of GRSG locations and individuals contained within selected habitats.

Methods: The authors monitored 122 marked GRSG between 2006 and 2010, and 3,690 locations were used to model habitat selection during the breeding, summer-fall, and winter seasons. Vegetation and topography covariates were quantified at multiple scales between 100 meters $(\mathrm{m})$ and 3.2 kilometers $(\mathrm{km})$. Areas containing 50-80 percent of GRSG locations and individuals across seasons were mapped to help prioritize habitats.

Location: northwestern Colorado; MZ VII

Findings: Top models of selected breeding season habitats suggested positive relations with sagebrush and barren and negative relations with forest, mesic mountain shrub, xeric shrub, terrain roughness, southern aspect, and distance to forest; variables were assessed at spatial scales from 100 to $2,400 \mathrm{~m}$. Top models for summer-fall habitat suggested positive relations with a more general sagebrush metric and barren and negative relations with forest, a different metric of barren areas, xeric shrubs, terrain roughness, southern aspect, and distance to forest. The top model for winter habitat suggested positive relations with sagebrush and barren and negative relations with forest, mesic mountain shrub, xeric shrubs, and terrain roughness. Models also included quadratic effects of elevation or a topographic index. The spatial scales of assessment for variables for both summer-fall and winter habitat ranged from $100 \mathrm{~m}$ to $3.2 \mathrm{~km}$. Seasonal use locations were quite concentrated, but larger areas were required to encompass use by $50-80$ percent of individuals because of individual variability in habitat use.

Implications: GRSG generally selected for vegetation characteristics at small spatial scales $(100-400 \mathrm{~m})$; terrain roughness was also a strong negative predictor at $100 \mathrm{~m}$ in all seasons. A mosaic of habitats with sagebrush are important in multiple seasons, and actions that increase sagebrush within $400 \mathrm{~m}$ and reduce forest within 100-400 m may be most beneficial.

Topics: behavior or demographics, broad-scale habitat characteristics, effect distances or spatial scale, habitat selection, new geospatial data, site-scale habitat characteristics 
*2019 Update* Wann, G.T., Coates, P.S., Prochazka, B.G, Severson, J.P., Monroe, A.P., and Aldridge C.L., 2019, Assessing lek attendance of male greater sage-grouse using fineresolution GPS data-implications for population monitoring of lek mating grouse: Population Ecology, v. 61, no. 2, p. 183-197.

DOI: https://doi.org/10.1002/1438-390X.1019

Background: How variability in male lek attendance relates to population trends has not been well studied. Understanding this pattern may be important for making management decisions based on population trends.

Objectives: The authors sought to: 1) evaluate within- and between-season variations in male lek attendance, 2) assess lek-switching rates, 3) compare modeled and observed lek attendance, and 4) date-correct observed lek counts using lek attendance probability.

Methods: From 2013 to 2017, the authors captured 67 male GRSG from eight populations and fitted them with GPS transmitters. Known active leks in the study area were surveyed and mapped. Using these data, the authors modeled the probability of male lek attendance and compared the values with predicted and observed lek counts and seasonal-scale variations in weather.

Location: Nevada; MZ III, MZ IV

Findings: Lek attendance and lek-switching was highly variable within and between seasons. A significantly greater proportion of males attended leks during wetter years, and the average date of peak lek season in the study area was April 16, which is earlier than in the Great Plains. Around a third of adult males visited more than one lek in a single season, generally before peak lek attendance, but lek-switching within the same morning was rare. The probability of lekswitching declined with distance between leks and fell to zero at $4 \mathrm{~km}$.

Implications: Lek-switching occurred at a higher rate than previously thought. Therefore, the authors recommended that surveys of leks within $4 \mathrm{~km}$ of each other should be conducted on the same morning to reduce the chance of double counting males. Date-corrected daily lek counts using attendance probability can reliably estimate population sizes, allowing more leks to be monitored less frequently and estimates to more closely track actual population sizes.

Topics: behavior or demographics, effect distances or spatial scale, population estimates or targets, weather and climate 
Westover, M., Baxter, J., Baxter, R., Day, C., Jensen, R., Petersen, S., and Larsen, R., 2016, Assessing greater sage-grouse selection of brood-rearing habitat using remotely-sensed imagery-Can readily available high-resolution imagery be used to identify brood-rearing habitat across a broad landscape?: PLoS ONE, v. 11, no. 5, article e0156290, 19 p.

DOI: https://doi.org/10.1371/journal.pone.0156290

Background: Limited availability of brood-rearing habitats has been identified as a factor affecting long-term conservation of GRSG. Many site-scale factors influencing brood-rearing habitat selection have been well studied. Given the large home range of GRSG, it is also important to understand landscape-scale factors affecting habitat selection. However, the spatial resolution of remotely sensed imagery commonly used to quantify landscape features may be coarser than the resolution GRSG are using to select habitats.

Objectives: Study objectives were (1) to quantify characteristics of brood-rearing habitat using high-resolution imagery, (2) to identify the spatial scale at which landscape features are related to selection of brood-rearing habitat, and (3) to model potential brood-rearing habitat across the study area.

Methods: Brooding GRSG were marked between 1998 and 2008, and 3,865 locations from those individuals were used to model selection of brood-rearing habitat using a large number of land cover, land use, topography, and patch variables, many of which were quantified at three spatial scales (45 meters [m], $200 \mathrm{~m}$, and $795 \mathrm{~m}$ ). Land cover, land use, and patch variables were quantified based on ten land cover classes developed from 1-m-resolution imagery from the U.S. Department of Agriculture's National Agricultural Imagery Program.

Location: north-central Utah, MZ III

Findings: The top model for selection of brood-rearing habitat suggested that multiple variables were negatively correlated with brood-habitat selection (percent cover of grass, trees, riparian, and paved roads; length of shrub/tree edge and riparian/tree edge; and increasing distance from power line), whereas percent shrub was positively correlated with brood-habitat selection. Most variables in the model were assessed at the 795-m spatial scale. The accuracy of the National Agricultural Imagery Program land-cover classification was 78.5 percent. ${ }^{*}$

Implications: The high spatial resolution of the land-cover product allowed the authors to identify the importance of edges for GRSG selection of brood-rearing habitat. Brood-rearing GRSG selected for habitat features at a variety of spatial extents from $45 \mathrm{~m}$ to $795 \mathrm{~m}$ and avoided edges between shrubs and trees and between tree and riparian land-cover types along with manmade structures (primarily cabins).

Topics: agricultural conversion, broad-scale habitat characteristics, effect distances or spatial scale, ex-urban development, habitat selection, infrastructure (roads, pipelines, powerlines, cell towers), new geospatial data, recreation, site-scale habitat characteristics 
${ }^{*}$ A correction to this paper has been published. It changes the caption for a figure but does not change the Findings or Implications described here.

Westover, M., Baxter, J., Baxter, R., Day, C., Jensen, R., Petersen, S., and Larsen, R., 2016, CorrectionAssessing greater sage-grouse selection of brood-rearing habitat using remotely-sensed imagery-Can readily available high-resolution imagery be used to identify brood-rearing habitat across a broad landscape?: PLoS ONE, v. 11, no. 8, article e0160725, 2 p., https://doi.org/10.1371/journal.pone.0160725. 


\section{Wing, B.R., and Messmer, T.A., 2016, Impact of sagebrush nutrients and monoterpenes on greater sage-grouse vital rates: Human-Wildlife Interactions, v. 10, no. 2, p. 157-168.}

DOI: https://doi.org/10.26077/5w03-n711

Background: GRSG winter diets consist largely of sagebrush. Secondary metabolites in sagebrush are a chemical defense against herbivory, but their effects on GRSG, including potential links between pre-nesting diet and nesting success, are not well studied.

Objectives: Study objectives were (1) to describe female GRSG foraging behavior during the pre-nesting season, (2) to quantify differences in nutritional quality and chemical composition of browsed versus available sagebrush, and (3) to identify relations between pre-nesting diets and vital rates of female GRSG.

Methods: The authors monitored 29 marked GRSG females in spring 2013 to determine prenesting diets and vital rates (nest initiation, apparent nest success, age of nesting females, egg fertility, clutch size, and female survival). Sagebrush was sampled in 70 browsed sites along with nearby nonbrowsed locations and analyzed for crude protein and monoterpene concentrations.

Location: northwestern Utah; MZ IV

Findings: The majority of browsed sites consisted of black sagebrush (versus big sagebrush subspecies), which had lower crude protein and higher total monoterpene concentrations than Wyoming big sagebrush. Crude protein and monoterpene concentration did not differ between browsed and nonbrowsed locations, and neither measure was related to any measured vital rate. All 10 nests initiated in black sagebrush areas with high concentrations of a single monoterpene succeeded, while all 9 nests initiated outside of these areas failed.

Implications: Study results confirmed the importance of black sagebrush as pre-nesting season forage and suggested that any forage selection related to monoterpenes may reflect some aspect of an individual monoterpene rather than the total concentration of all monoterpenes. Study results should be interpreted cautiously because of the small sample size, single year, and single study site.

Topics: behavior or demographics, habitat selection, site-scale habitat characteristics, survival 


\section{Wollstein, K.L., and Davis, E.J., 2017, A "hammer held over their heads"-Voluntary conservation spurred by the prospect of regulatory enforcement in Oregon: Human- Wildlife Interactions, v. 11, no. 3, p. 258-273.}

DOI: https://doi.org/10.26077/wrwp-f416

Background: Regulatory approaches to wildlife conservation, such as Section 9 of the Endangered Species Act of 1973, which prohibits actions on private land that may result in take of an endangered species or indirect harm through habitat modification that affects essential behavior patterns, can be perceived as a threat to private property rights. Voluntary approaches to conservation on private lands may be an alternative, but our understanding of factors that motivate rangeland landowners to participate in such efforts is limited.

Objectives: The study objective was to identify aspects of voluntary conservation programs for GRSG that motivated participation by private landowners.

Methods: The study was conducted in Lake County, Oregon, where livestock grazing is the dominant land use and where there was a high rate of landowner participation in U.S. Fish and Wildlife Service Candidate Conservation Agreements with Assurances for GRSG. The qualitative case study was founded on 20 semi-structured interviews with landowners and employees of agencies and nongovernmental organizations, as well as document analysis.

\section{Location: Oregon; MZ V}

Findings: Features of voluntary GRSG conservation measures that landowners mentioned most often as incentives were property rights retention, alignment with agricultural production goals, receipt of financial assistance, and promotion of healthy rangelands. Agency and nongovernmental organization employees also referenced property rights and financial assistance, as well as a proactive nature and leadership from individuals representing the agency or organization.

Implications: Flexibility in multiple aspects of the voluntary conservation measures and financial assistance were commonly referenced incentives by all parties. In many cases, financial assistance supported rangeland improvement actions that ranchers had been wanting to implement (such as conifer removal) but did not previously have the financial means to do so. Trusted local leaders and agency managers played a key role in fostering landowner participation in voluntary conservation efforts, as did the potential threat of regulatory action. For devising conservation strategies on private rangelands, authors recommended (1) aligning conservation options with producers' goals, (2) improving ease of implementation by routing options through trusted leaders or organizations, and (3) providing financial and technical resources that make conservation less economically risky and within the realm of possibility for landowners.

Topics: herbivory/grazing, human dimensions or economics 
Zabihi, K., Paige, G.B., Hild, A.L., Miller, S.N., Wuenschel, A., and Holloran, M.J., 2017, A fuzzy logic approach to analyse the suitability of nesting habitat for greater sage-grouse in western Wyoming: Journal of Spatial Science, v. 62, no. 2, p. 215-234.

DOI: https://doi.org/10.1080/14498596.2017.1292965

Background: Fuzzy-logic approaches to modeling habitat suitability can facilitate understanding of the model by stakeholders and allow for incorporation of imprecise and uncertain information and expert knowledge and opinion. Use of multiple information sources can improve understanding of GRSG nesting habitat suitability and potentially reduce bias from limited sample sizes or sampling effort.

Objectives: The study objective was to model and map GRSG nesting habitat suitability using a combination of fine- and broad-scale environmental variables.

Methods: The authors identified 80 nest sites in 2009 and 2010 and quantified seven variables at each: slope, aspect, land cover, and canopy cover and distance to well pads, two-track roads, and main gravel roads. Vegetative cover was measured at each nest site and correlated with imagery from the U.S. Department of Agriculture's National Agricultural Imagery Program to characterize canopy cover. Variables were assigned fuzzy scores using fuzzy scoring functions developed from the literature or surveyed sites. Variables were combined by using a product of the fuzzy sum and fuzzy multiplication.

Location: west-central Wyoming; MZ II

Findings: Five classes of nesting habitat suitability were mapped, and more than 75 percent of validation nests were found in areas mapped as medium-high to high suitability. Subjective sensitivity analyses indicated that all variables were important in identifying the distribution of suitable nesting habitat and that canopy cover and the anthropogenic variables, especially distance from main gravel roads, were most important in differentiating among habitat suitability classes.

Implications: A fuzzy-logic approach is a relatively straightforward way to use quantitative data and expert knowledge together to map multiple habitat suitability classes, which can inform management.

Topics: broad-scale habitat characteristics, energy development, habitat selection, infrastructure (roads, pipelines, powerlines, cell towers), new geospatial data, site-scale habitat characteristics 
Publishing support provided by the U.S. Geological Survey Science Publishing Network, Tacoma Publishing Service Center

For more information concerning the research in this report, contact the Director, Fort Collins Science Center

U.S. Geological Survey

2150 Centre Ave., Building C

Fort Collins, CO 80526-8118

https://www.usgs.gov/centers/fort 
